FE566

\title{
Economic Impacts of the Green Industry in the United States
}

\author{
Final Report to the National Urban and Community Forestry Advisory Committee
}

by

\author{
Charles R. Hall, PhD, University of Tennessee \\ 2621 Morgan Circle Room 314B, Knoxville, TN 37996 \\ crh@utk.edu \\ Alan W. Hodges, PhD, University of Florida \\ PO Box 110240, Gainesville, FL 32611 \\ awhodges@ufl.edu \\ John J. Haydu, PhD, University of Florida \\ 2725 Binion Rd, Apopka, FL 32703 \\ jih@ifas.ufl.edu
}

Revised June 3, 2005

\section{Acknowledgements}

This research report was made possible by a grant from USDA-Forest Service, National Urban and Community Forestry Advisory Committee, along with funding from the American Nursery and Landscape Association (ANLA) and the Associated Landscape Contractors of America (formerly ALCA, now PLANET - the Professional Landcare Network). Others who contributed to the effort by providing information or technical reviews included John Brooker (University of Tennessee), David Mulkey and Tom Stevens (University of Florida), Jennifer Dennis (Purdue University), and members of the Green Industry Research Consortium (S-290 Multi-State Research Committee of USDA-CSREES). 


\section{Table of Contents}

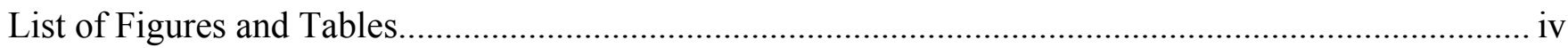

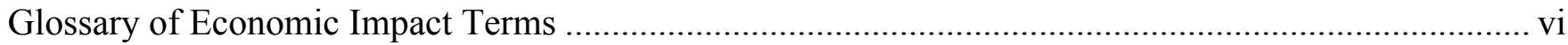

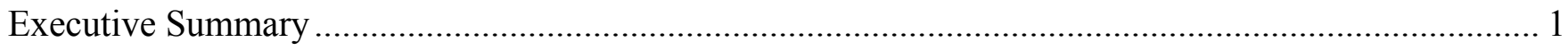

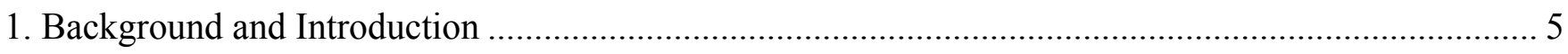

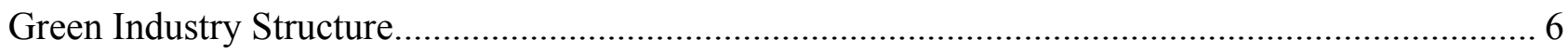

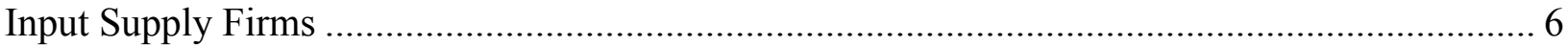

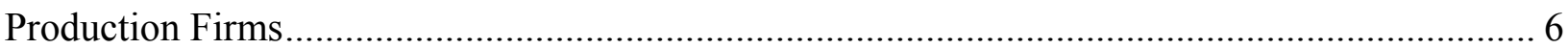

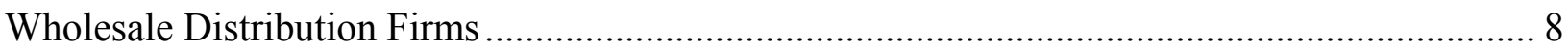

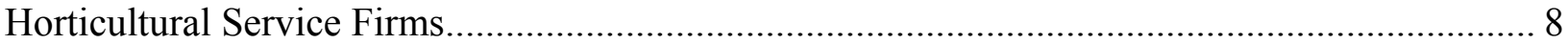

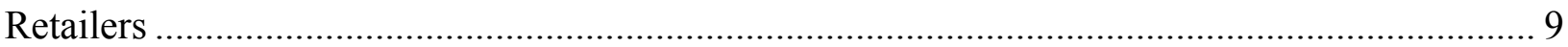

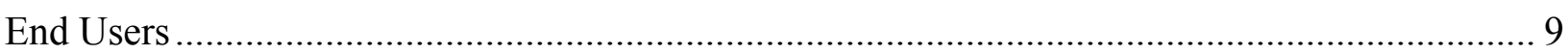

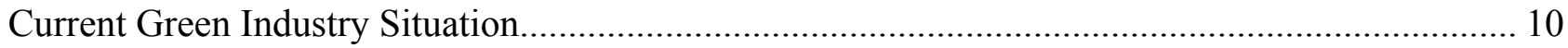

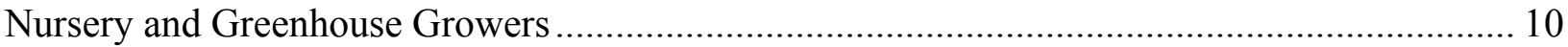

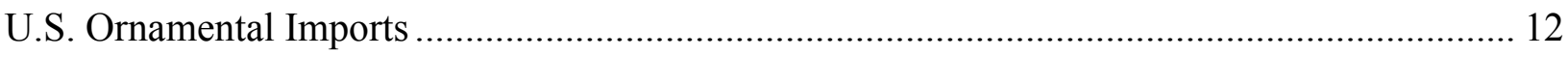

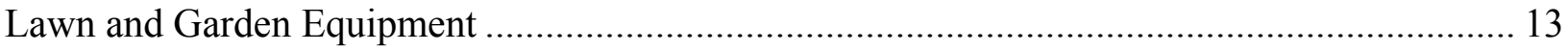

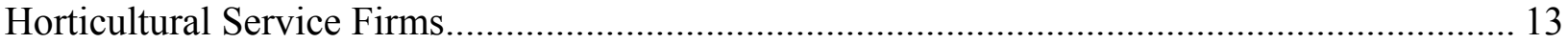

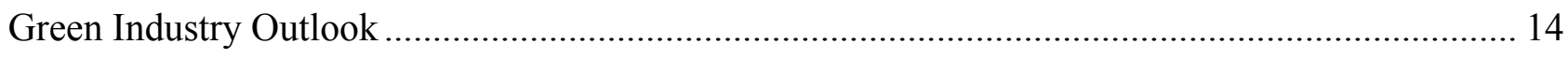

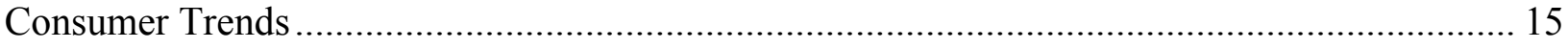

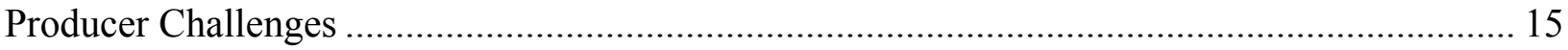

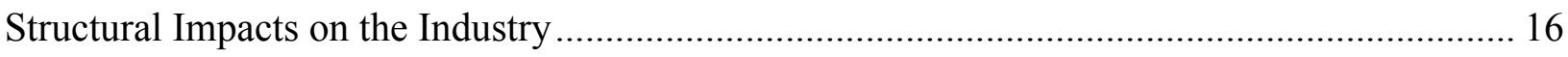

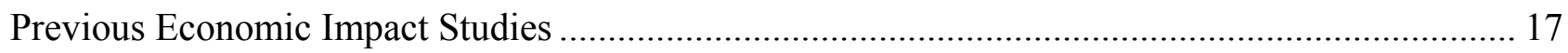

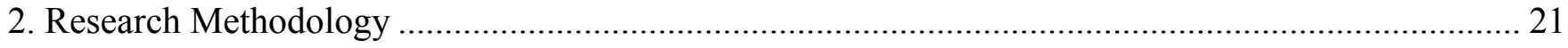

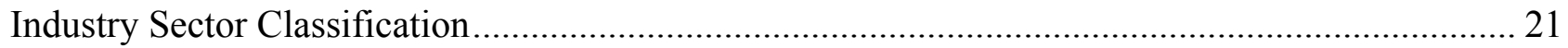

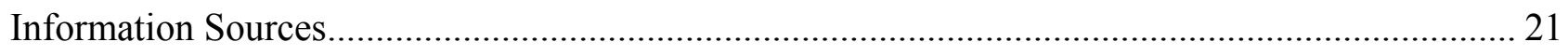

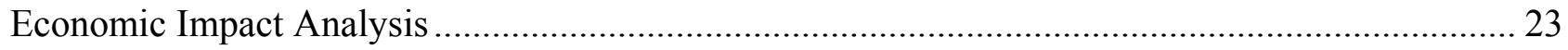

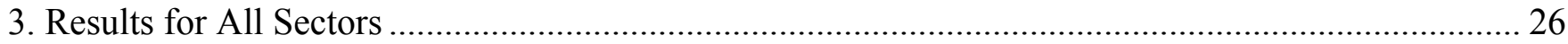

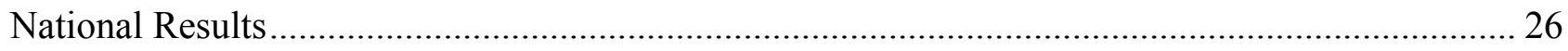

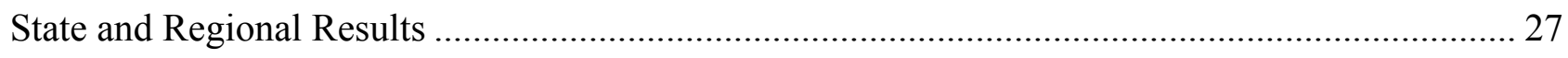

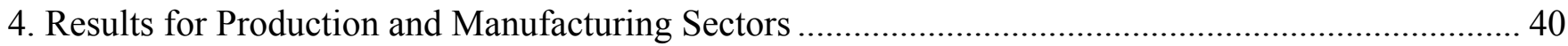

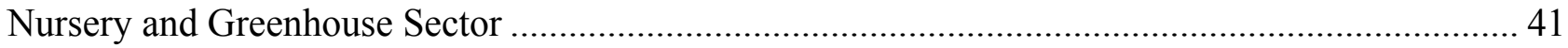

Lawn and Garden Equipment and Greenhouse Manufacturing Sectors............................................ 42 


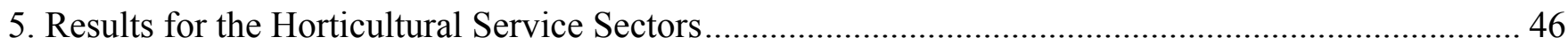

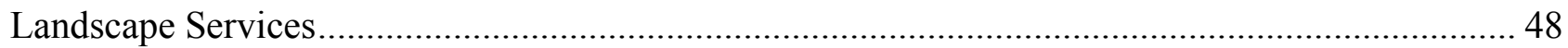

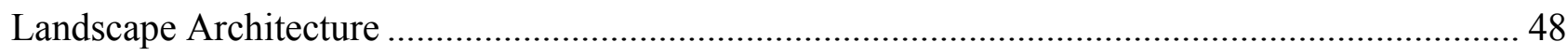

6. Results for the Wholesale and Retail Trade Sectors ......................................................... 51

Wholesale Flower, Nursery Stock \& Florist Supply ............................................................ 52

Wholesale Lawn \& Garden Equipment Distributors .............................................................. 52

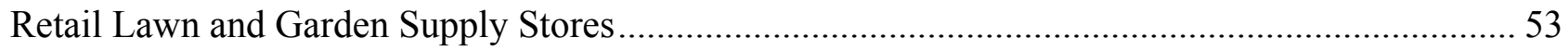

Retail Building Materials and Supply Stores........................................................................ 53

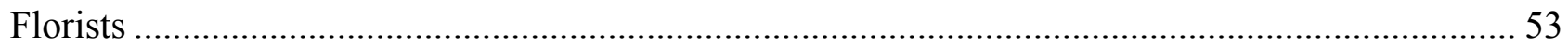

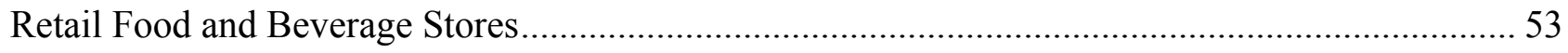

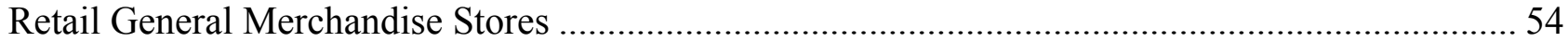

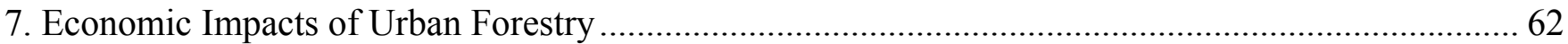

Economic Impacts of Tree Sales and Tree Care Services ..................................................... 62

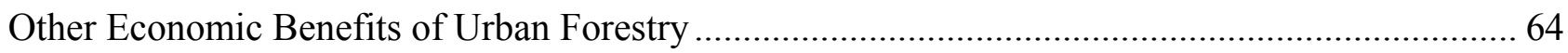

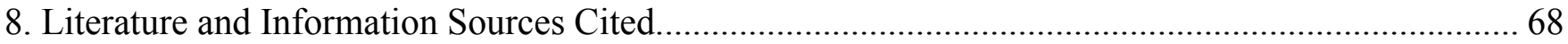

Appendix A--Economic Multipliers for the U.S. Green Industry Sectors....................................... 72 


\section{List of Figures and Tables}

Table ES-1. Summary of Economic Impacts of the U.S. Green Industry by Sector, 2002 _................... 2 Figure ES-1. Output Impacts of the U.S. Green Industry, by Region and Industry Group, 2002 ............ 2 Table ES-2. Economic Impacts of the U.S. Green Industry by Region/State and Industry Group, 2002 .. 3 Figure ES-2. Employment Impacts of the U.S. Green Industry, by Region and Industry Group, 2002 .... 4 Table 1-1. U.S. Households Purchasing Lawn and Garden Products, By Type of Outlet, 2003 .............. 9

Figure 1-1. Growth in Output of US Green Industry Sectors, 1987-2003 ..................................... 10

Table 1-2. Summary of Selected Recent Studies on Economic Impacts of the Green Industry in

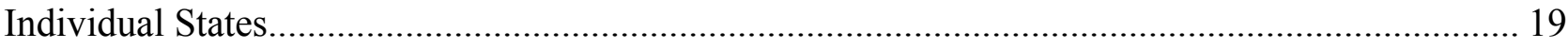

Table 1-3. State-Specific Studies of Economic Impacts of the Green Industry, 1978-2004 ................. 20

Table 2-1. Classification of Economic Sectors Associated with the Green Industry ............................ 21

Table 2-2. Sales and Employment in the U.S. Green Industry, 2002 .............................................. 22

Table 2-3. Implan Sectors Used for Economic Impact Analysis of the Green Industry ....................... 24

Figure 2-1. Market Structure and Economic Linkages of the Green Industry................................... 24

Table 2-4. Output Total Effects Multipliers for the Green Industry, by Sector and State (2001) ........... 25

Table 3-1. Economic Impacts of the U.S. Green Industry, by Sector, 2002 .................................... 26

Table 3-2. Economic Impacts of the U.S. Green Industry by State/Region and Industry Group, 2002 ... 27

Figure 3-1. Output Impacts of the U.S. Green Industry by Region and Industry Group, 2002 ............. 29

Figure 3-2. Employment Impacts of the U.S. Green Industry by Region and Industry Group, 2002 ..... 29

Figure 3-3. Value added Impacts of the U.S. Green Industry by Region and Industry Group, 2002 ...... 30

Table 3-3. Output Impacts of the U.S. Green Industry by Sector and State, 2002 …......................... 31

Figure 3-4. Output Impacts of the U.S. Green Industry by State and Industry Group, 2002 ................. 32

Table 3-4. Employment Impacts of the U.S. Green Industry by Sector and State, 2002 ..................... 33

Figure 3-5. Employment Impacts of the U.S. Green Industry by State and Industry Group, 2002 ......... 34

Table 3-5. Value Added Impacts of the U.S. Green Industry by Sector and State, 2002 ...................... 35

Figure 3-6. Value Added Impacts of the U.S. Green Industry by State and Industry Group, 2002 ........ 36

Figure 3-7. Output Impacts of the U.S. Green Industry in Leading States, 2002 .............................. 37

Figure 3-8. Employment Impacts of the U.S. Green Industry in Leading States, 2002 ........................ 37

Figure 3-9. Value Added Impacts of the U.S. Green Industry in Leading States, 2002 ....................... 38

Figure 3-10. Rank Order of States by Green Industry Share of Gross State Product, 2002 ................... 38

Table 3-6. Green Industry Share of Gross State Product, 2002 .................................................... 39

Table 4-1. Products Included in the Production and Manufacturing Sectors of the Green Industry ....... 40

Table 4-2. Establishments, Employment, Payroll and Sales in Production and Manufacturing Sectors of

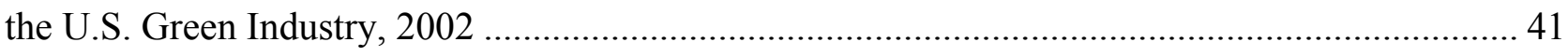

Table 4-3. Economic Impacts of the Production and Manufacturing Sectors of the U.S. Green Industry,

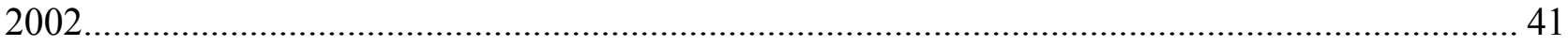

Table 4-4. Economic Impacts of the U.S. Nursery and Greenhouse Sector by State, 2002 .................. 43 
Table 4-5. Economic Impacts of the U.S. Lawn \& Garden Equipment Manufacturing Sector by State, 2002

Table 4.6. Economic Impacts of the U.S. Greenhouse Manufacturing Sector by State, 2002 ................. 45

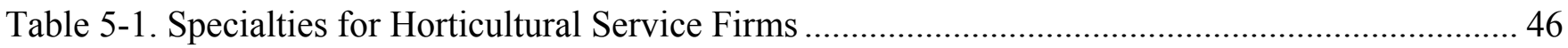

Table 5-2. Sales and Employment in the U.S. Horticultural Services Sectors, 2002 ................................ 47

Table 5-3. Economic Impacts of the U.S. Horticultural Services Sectors, 2002 ...................................... 48

Table 5-4. Economic Impacts of the U.S. Landscaping Services Sector by State, 2002 ........................... 49

Table 5-5. Economic Impacts of the U.S. Landscape Architecture Sector by State, 2002 ....................... 50

Table 6-1. Output, Employment and Payroll in the U.S. Environmental Horticulture Wholesale and

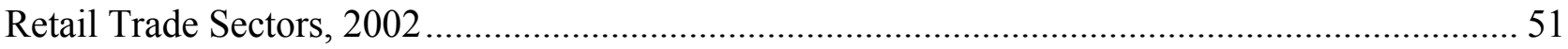

Table 6-2. Economic Impacts of the U.S. Environmental Horticulture Wholesale and Retail Trade

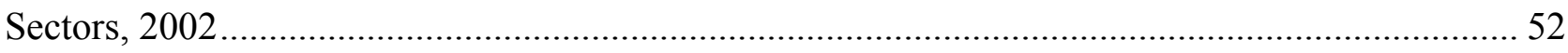

Table 6-3. Economic Impacts of the U.S. Wholesale Flower, Nursery Stock \& Florist Supply Sector by State, 2002 .

Table 6-4. Economic Impacts of the U.S. Wholesale Lawn \& Garden Equipment Sector by State, 2002

Table 6-5. Economic Impacts of the U.S. Retail Lawn and Garden Supply Stores Sector by State, 2002

Table 6-6. Economic Impacts of the U.S. Retail Building Materials and Supply Stores Sector by State,

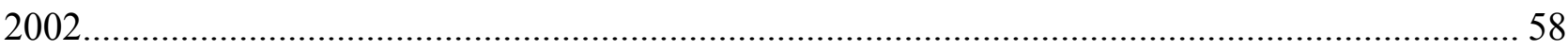

Table 6-7. Economic Impacts of the U.S. Florists Sector by State, 2002 ………………………......... 59

Table 6-8. Economic Impacts of the U.S. Retail Food and Beverage Stores Sector by State, 2002 ........ 60

Table 6-9. Economic Impacts of the U.S. Retail General Merchandise Stores Sector by State, 2002 ..... 61

Table 7-1. Economic Impacts of U.S. Urban Forestry Tree Sales and Tree Care Services, 2002 ........... 63

Appendix Table A-1. Multipliers for the Nursery and Greenhouse Sector ............................................. 72

Appendix Table A-2. Multipliers for the Lawn and Garden Equipment Manufacturing Sector............... 73

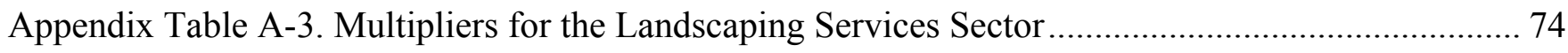

Appendix Table A-4. Multipliers for the Landscape Architecture Sector................................................ 75

Appendix Table A-5. Multipliers for the Wholesale Flowers, Nursery Stock and Florist Supply, and

Wholesale Equipment Distribution Sectors (Wholesale Trade) ……………………...................... 76

Appendix Table A-6. Multipliers for the Lawn and Garden Store and Building Materials \& Supplies

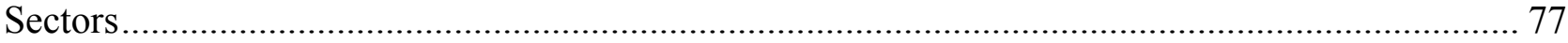

Appendix Table A-7. Multipliers for the Florist Sector (Miscellaneous Retail Stores) …........................ 78

Appendix Table A-8. Multipliers for the Food and Beverage Stores Sector ............................................ 79

Appendix Table A-9. Multipliers for the General Merchandise Stores Sector............................................. 80

Appendix Figure A-1. Detailed Structure of the Green Industry in the United States ............................. 81 


\section{Glossary of Economic Impact Terms}

\section{Terms are presented in groups within a logical rather than alphabetical order}

Region defines the geographic area for which impacts are estimated. Regions are generally an aggregation of one or more counties. This analysis includes estimates for individual states of the U.S.

Sector is a grouping of industries that produce similar products or services. Most economic reporting and models in the U.S. are based on the Standard Industrial Classification system (SIC code) or the North American Industrial Classification System (NAICS).

Impact analysis estimates the impact of a change in output or employment resulting from a change in final demand to households, governments or exports.

Input-output (I-O) model. An input-output model is a representation of the flows of economic activity between industry sectors within a region. The model captures what each business or sector must purchase from every other sector in order to produce its output of goods or services. Using such a model, flows of economic activity associated with any change in spending may be traced either forwards (e.g., spending generates employee wages which induces further spending) or backwards (e.g., purchases of plants that leads growers to purchase additional inputs -- fertilizers, containers, etc.). Multipliers for a region may be derived from an input-output model of the region's economy.

IMPLAN is a micro-computer-based input output modeling system and Social Accounting Matrix (SAM). With IMPLAN, one can estimate I-O models of up to 528 sectors for any region consisting of one or more counties. IMPLAN includes procedures for generating multipliers and estimating impacts by applying final demand changes to the model. The current version of the software is IMPLAN Pro 2.0.

Final Demand is the term for sales to final consumers (households or government). Sales between industries are termed intermediate sales. Economic impact analysis generally estimates the regional economic impacts of final demand changes.

Direct effects are the changes in economic activity during the first round of spending. Secondary effects are the changes in economic activity from subsequent rounds of re-spending. There are two types of secondary effects: Indirect effects are the changes in sales, income or employment within the region in backward-linked industries supplying goods and services to businesses. For example, the increased sales in input supply firms resulting from more nursery industry sales is an indirect effect. Induced effects are the increased sales within the region from household spending of the income earned in the Green Industry and supporting industries. Employees in the Green Industry and supporting industries spend the income they earn on housing, utilities, groceries, and other consumer goods and services. This generates sales, income and employment throughout the region's economy. Total effects are the sum of direct, indirect and induced effects.

Multipliers capture the size of the secondary effects in a given region, generally as a ratio of the total change in economic activity in the region relative to the direct change. Multipliers may be expressed as ratios of sales, income or employment, or as ratios of total income or employment changes relative to direct sales. Multipliers express the degree of interdependency between sectors in a region's economy and therefore vary considerably across regions and sectors. Type I multipliers include only direct and indirect effects. Type II multipliers also include induced effects. Type SAM multipliers used by IMPLAN additionally account for capital investments and transfer payments such as welfare and retirement income. A sector-specific multiplier gives the total changes to the economy associated with a unit change in output or employment in a given sector. Aggregate multipliers sum multiplier effects across many sectors with a single number. They are based on an assumed distribution of spending across these economic sectors, i.e., a weighted average of sector specific multipliers with the percentage of spending in each sector as the weighting factor. 
Purchaser prices are the prices paid by the final consumer of a good or service. Producer prices are the prices of goods at the factory or production point. For manufactured goods the purchaser price equals the producer price plus a retail margin, a wholesale margin, and a transportation margin. For services, the producer and purchaser prices are equivalent.

Margins. The retail, wholesale and transportation margins are the portions of the purchaser price accruing to the retailer, wholesaler, and grower, respectively. Only the retail margins of many goods purchased by consumers accrue to the local region, as the wholesaler, shipper, and manufacturer often lie outside the local area.

Measures of economic activity. Sales or output is the dollar volume of a good or service produced or sold. Final Demand is sales to final consumers, including households, governments, and exports. Intermediate sales are sales to other industrial sectors. Income is the money earned within the region from production and sales. Total income includes personal income (wage and salary income, including income of sole proprietor's profits and rents). Jobs or employment is a measure of the number of jobs required to produce a given volume of sales/production, usually expressed as full time equivalents, or as the total number including part time and seasonal positions. Value Added is the sum of total income and indirect business taxes. Value added is the most commonly used measure of the contribution of a region to the national economy, as it avoids double counting of intermediate sales and captures only the "value added" by the region to final products. 


\section{Executive Summary}

The environmental horticulture industry, also known as the "Green Industry", is comprised of a variety of businesses involved in production, distribution and services associated with ornamental plants, landscape and garden supplies and equipment. Segments of the industry include wholesale nursery, greenhouse and sod growers, landscape architects, contractors and maintenance firms, retail garden centers, home centers and mass merchandisers with lawn and garden departments, and marketing intermediaries such as brokers, horticultural distribution centers, and re-wholesalers. In addition to these commercial sectors, many state and local governments have significant urban forestry operations for management of parks, botanic gardens, and right-ofways that are an integral segment of community infrastructure. The Green Industry is linked to urban forestry by providing quality plant material and professional personnel with specialized expertise for growing, maintaining, and managing city trees.

Environmental horticulture is one of the fastest growing segments of the nation's agricultural economy, often experiencing growth and expansion even during recessionary periods. The nursery and greenhouse sector has experienced considerable growth in the last two decades, albeit slowing somewhat in recent years. The landscape design, construction, and maintenance sector has also expanded due to strong economic conditions and robust building activity. Retail sales of horticultural goods have increased for both independent and chain-store type retailers, with considerable consolidation occurring due to the increased presence of home centers and mass merchants in the lawn and garden marketplace. The outlook for the Green Industry is promising, yet there are several challenges that will increase competitive pressures.

In view of its importance, numerous studies have been conducted to document the Green Industry's economic impacts in individual states or regions, however, the present study represents the first attempt to evaluate it economic impacts for the entire United States, using data from previous studies together with secondary industry statistics. A specific objective of the study was to evaluate the role, value and economic impact of forest tree species (woody ornamental trees) in the urban forestry environment.

Nationwide estimates of the economic impacts of the Green Industry were derived from a variety of information sources, including industry statistics from the U.S. Economic Census and Census of Agriculture (2002), County Business Patterns, and primary surveys by horticulture economics researchers. Economic impacts for each state were computed using the Implan Pro software to build regional input-output models to derive economic multipliers that estimate the indirect effects of industry purchases and induced effects of employee household spending, and also capture the effects of taxes and transfer payments.

Economic impacts for the U.S. Green Industry in 2002 were estimated at $\$ 147.8$ billion (Bn) in output, 1,964,339 jobs, $\$ 95.1 \mathrm{Bn}$ in value added, $\$ 64.3 \mathrm{Bn}$ in labor income, and $\$ 6.9 \mathrm{Bn}$ in indirect business taxes, with these values expressed in 2004 dollars (Table ES-1). For the production and manufacturing sectors, including nurseries/greenhouses, lawn and garden equipment manufacturers, and greenhouse manufacturers, total output impacts were $\$ 34.6 \mathrm{Bn}$, employment impacts were 300,677 jobs, and value added impacts were $\$ 20.8 \mathrm{Bn}$. For the horticultural services sectors of landscape services and landscape architects, total output impacts were $\$ 57.8 \mathrm{Bn}$, employment impacts were 753,557 jobs, and value added impacts were $\$ 39.0 \mathrm{Bn}$. For the wholesale/retail trade sectors, total output impacts were $\$ 55.5 \mathrm{Bn}$, employment impacts were 910,104 jobs, and value added impacts were $\$ 35.3 \mathrm{Bn}$. The largest individual sectors in terms of employment and value added impacts were landscaping services (704,875 jobs, $\$ 35.6 \mathrm{Bn})$, lawn and garden stores $(347,916$ jobs, $\$ 14.8 \mathrm{Bn})$, nursery and greenhouses (261,408 jobs, $\$ 18.1 \mathrm{Bn})$, florists (200,451 jobs, $\$ 4.0 \mathrm{Bn})$, and building material supply stores (123,591 jobs, $\$ 6.5$ $\mathrm{Bn})$. Other sectors with large value added impacts were general merchandise stores $(\$ 4.0 \mathrm{Bn})$, landscape architects $(\$ 3.5 \mathrm{Bn})$, lawn and garden equipment manufacturers $(\$ 2.6 \mathrm{Bn})$, lawn and garden equipment wholesalers $(\$ 2.7 \mathrm{Bn})$, wholesale flower, nursery stock and florist supplies $(\$ 1.9 \mathrm{Bn})$, and food \& beverage stores (\$1.4 Bn).

Economic impact results are reported by state and region, as summarized in Table ES-2, Figures ES-1 and ES-2. Total value added impacts were largest in the Midwest region ( $\$ 19.2 \mathrm{Bn})$, followed by the Pacific region $(\$ 18.4$ $\mathrm{Bn})$, Northeast $(\$ 17.9 \mathrm{Bn})$, and Southeast $(\$ 13.5 \mathrm{Bn})$. The largest individual states in terms of value added 
impacts, all exceeding \$3 billion, were California ( $\$ 13.7 \mathrm{Bn})$, Florida $(\$ 7.1 \mathrm{Bn})$, Texas $(\$ 6.1 \mathrm{Bn})$, Illinois $(\$ 4.3$ Bn), Pennsylvania (\$3.7 Bn), New York (\$3.5 Bn), and Ohio (\$3.5 Bn).

Table ES-1. Summary of Economic Impacts of the U.S. Green Industry by Sector, 2002

\begin{tabular}{|c|c|c|c|c|c|}
\hline Industry Group/Sector (NAICS) & $\begin{array}{l}\text { Output } \\
(\$ M n)^{*}\end{array}$ & $\begin{array}{c}\text { Employ- } \\
\text { ment } \\
\text { (jobs) }\end{array}$ & $\begin{array}{l}\text { Value } \\
\text { Added } \\
(\$ M n)^{*}\end{array}$ & $\begin{array}{l}\text { Labor } \\
\text { Income } \\
(\$ M n)^{*}\end{array}$ & $\begin{array}{c}\text { Indirect } \\
\text { Business } \\
\text { Taxes } \\
(\$ \mathrm{Mn})^{*}\end{array}$ \\
\hline Production \& Manufacturing & 34,578 & 300,677 & 20,796 & 11,037 & 784 \\
\hline Nursery \& Greenhouse (1114) & 26,053 & 261,408 & 18,076 & 9,612 & 647 \\
\hline Lawn \& Garden Equipment Mfg (333112) & 8,281 & 37,343 & 2,610 & 1,346 & 129 \\
\hline Greenhouse Mfg (332311) & 244 & 1,927 & 110 & 78 & 7 \\
\hline Horticultural Services & 57,774 & 753,557 & 39,013 & 30,269 & 1,387 \\
\hline Landscaping Services (56173) & 52,971 & 704,875 & 35,564 & 27,719 & 1,312 \\
\hline Landscape Architecture (54132) & 4,803 & 48,683 & 3,449 & 2,549 & 74 \\
\hline Wholesale \& Retail Trade & 55,475 & 910,104 & 35,275 & 23,044 & 4,701 \\
\hline $\begin{array}{l}\text { Wholesale Flowers, Nursery Stock and } \\
\text { Florist Supplies (42293) }\end{array}$ & 2,879 & 68,969 & 1,907 & 1,130 & 440 \\
\hline Garden Equipment Wholesale (421820) & 4,146 & 40,617 & 2,737 & 1,601 & 657 \\
\hline Lawn \& Garden Stores (4442) & 22,859 & 347,916 & 14,806 & 9,747 & 1,810 \\
\hline Building Material Supply Stores (4441) & 9,982 & 123,591 & 6,491 & 4,258 & 789 \\
\hline Florists (4531) & 7,195 & 200,451 & 3,977 & 2,725 & 401 \\
\hline Food \& beverage stores $(445)$ & 2,263 & 35,117 & 1,385 & 944 & 156 \\
\hline General merchandise stores (452) & 6,150 & 93,443 & 3,973 & 2,639 & 448 \\
\hline Total All Sectors & 147,828 & $1,964,339$ & 95,084 & 64,349 & 6,872 \\
\hline
\end{tabular}

* Values expressed in 2004 dollars (GDP Implicit Price Deflator, U.S. Department of Commerce)

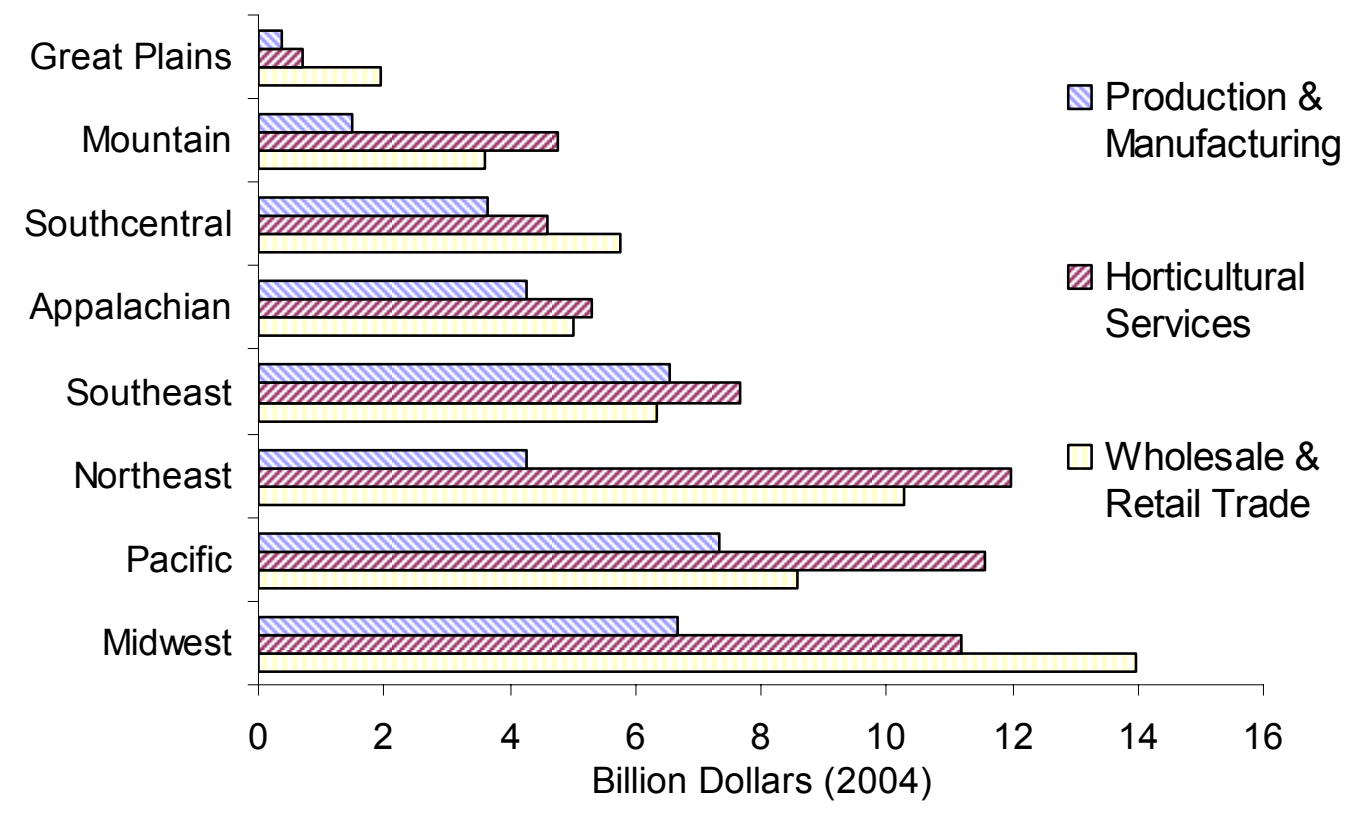

Figure ES-1. Output Impacts of the U.S. Green Industry, by Region and Industry Group, 2002 
Table ES-2. Economic Impacts of the U.S. Green Industry by Region/State and Industry Group, 2002

\begin{tabular}{|c|c|c|c|c|c|c|}
\hline \multirow[b]{2}{*}{ Region or State } & \multirow{2}{*}{$\begin{array}{l}\text { Output } \\
\text { Impacts } \\
(\$ M n)^{*}\end{array}$} & \multirow{2}{*}{$\begin{array}{l}\text { Employment } \\
\text { Impacts (jobs) }\end{array}$} & \multicolumn{4}{|c|}{ Value Added Impacts (\$Mn)* } \\
\hline & & & All Sectors & $\begin{array}{l}\text { Production \& } \\
\text { Manufact. }\end{array}$ & $\begin{array}{l}\text { Horticultural } \\
\text { Services }\end{array}$ & $\begin{array}{l}\text { Wholesale \& } \\
\text { Retail Trade }\end{array}$ \\
\hline East & 41,118 & 540,496 & 27,033 & 5,494 & 11,749 & 9,790 \\
\hline Northeast & 26,568 & 336,027 & 17,867 & 2,986 & 8,250 & 6,632 \\
\hline Connecticut & 2,350 & 27,026 & 1,659 & 375 & 787 & 496 \\
\hline Delaware & 448 & 6,359 & 297 & 44 & 148 & 104 \\
\hline Maine & 509 & 7,825 & 331 & 39 & 166 & 126 \\
\hline Maryland & 3,524 & 46,725 & 2,440 & 478 & 1,230 & 732 \\
\hline Massachusetts & 3,239 & 37,553 & 2,159 & 122 & 1,225 & 811 \\
\hline New Hampshire & 729 & 10,153 & 465 & 63 & 208 & 194 \\
\hline New Jersey & 4,210 & 52,929 & 2,875 & 436 & 1,459 & 980 \\
\hline New York & 5,265 & 62,113 & 3,511 & 437 & 1,363 & 1,711 \\
\hline Pennsylvania & 5,589 & 75,829 & 3,672 & 924 & 1,430 & 1,319 \\
\hline Rhode Island & 403 & 5,289 & 262 & 41 & 156 & 65 \\
\hline Vermont & 302 & 4,225 & 196 & 25 & 78 & 93 \\
\hline Appalachian & 14,550 & 204,469 & 9,166 & 2,508 & 3,500 & 3,159 \\
\hline Kentucky & 1,257 & 21,649 & 821 & 112 & 245 & 464 \\
\hline North Carolina & 5,155 & 67,472 & 3,583 & 1,387 & 1,261 & 935 \\
\hline Tennessee & 3,854 & 50,812 & 2,050 & 689 & 648 & 713 \\
\hline Virginia & 3,914 & 56,905 & 2,493 & 308 & 1,249 & 936 \\
\hline West Virginia & 371 & 7,631 & 220 & 13 & 96 & 111 \\
\hline Central & 34,825 & 439,955 & 21,070 & 3,142 & 7,958 & 9,970 \\
\hline Midwest & $\mathbf{3 1 , 8 2 5}$ & 397,099 & 19,243 & 2,994 & 7,494 & 8,754 \\
\hline Illinois & 6,897 & 75,110 & 4,335 & 430 & 1,972 & 1,933 \\
\hline Indiana & 3,010 & 41,714 & 1,804 & 229 & 745 & 830 \\
\hline Iowa & 1,459 & 20,820 & 906 & 62 & 216 & 627 \\
\hline Michigan & 4,845 & 58,745 & 2,991 & 564 & 1,221 & 1,205 \\
\hline Minnesota & 3,099 & 37,696 & 1,864 & 237 & 616 & 1,010 \\
\hline Missouri & 2,488 & 37,690 & 1,495 & 134 & 470 & 890 \\
\hline Ohio & 5,855 & 79,841 & 3,532 & 607 & 1,556 & 1,369 \\
\hline Wisconsin & 4,170 & 45,483 & 2,317 & 731 & 697 & 890 \\
\hline Great Plains & 2,999 & 42,855 & 1,827 & 147 & 463 & 1,216 \\
\hline Kansas & 1,362 & 19,316 & 813 & 93 & 274 & 446 \\
\hline Nebraska & 961 & 13,383 & 596 & 32 & 141 & 424 \\
\hline North Dakota & 307 & 4,500 & 189 & 9 & 21 & 160 \\
\hline South Dakota & 369 & 5,657 & 228 & 13 & 28 & 187 \\
\hline South & $\mathbf{3 4 , 5 5 9}$ & 498,420 & 22,150 & 6,301 & 8,194 & 7,656 \\
\hline Southcentral & 13,992 & 209,935 & 8,615 & 1,974 & 3,039 & 3,602 \\
\hline Arkansas & 1,395 & 16,680 & 675 & 195 & 166 & 315 \\
\hline Louisiana & 1,069 & 19,617 & 679 & 100 & 173 & 406 \\
\hline New Mexico & 520 & 8,739 & 353 & 72 & 137 & 145 \\
\hline Oklahoma & 1,352 & 24,603 & 819 & 247 & 212 & 359 \\
\hline Texas & 9,656 & 140,295 & 6,088 & 1,360 & 2,351 & 2,377 \\
\hline Southeast & 20,568 & 288,486 & 13,535 & 4,327 & 5,155 & 4,054 \\
\hline Alabama & 1,681 & 26,804 & 1,148 & 353 & 434 & 360 \\
\hline Florida & 9,997 & 147,795 & 7,076 & 2,463 & 2,747 & 1,866 \\
\hline Georgia & 4,726 & 62,493 & 3,020 & 644 & 1,213 & 1,162 \\
\hline Mississippi & 977 & 14,236 & 548 & 120 & 122 & 306 \\
\hline South Carolina & 3,187 & 37,157 & 1,745 & 747 & 638 & 359 \\
\hline West & 37,326 & 485,467 & $\mathbf{2 4 , 8 3 0}$ & 5,859 & 11,112 & $\mathbf{7 , 8 5 9}$ \\
\hline Mountain & $\mathbf{9 , 8 2 4}$ & 132,982 & 6,449 & 954 & 3,185 & 2,309 \\
\hline Arizona & 3,206 & 43,882 & 2,081 & 506 & 1,013 & 563 \\
\hline Colorado & 3,085 & 37,630 & 2,019 & 178 & 1,083 & 758 \\
\hline
\end{tabular}




\begin{tabular}{|c|c|c|c|c|c|c|}
\hline \multirow{2}{*}{ Region or State } & \multirow{2}{*}{$\begin{array}{l}\text { Output } \\
\text { Impacts } \\
\text { (\$Mn)* }\end{array}$} & \multirow{2}{*}{$\begin{array}{l}\text { Employment } \\
\text { Impacts (jobs) }\end{array}$} & \multicolumn{4}{|c|}{ Value Added Impacts (\$Mn)* } \\
\hline & & & All Sectors & $\begin{array}{l}\text { Production \& } \\
\text { Manufact. }\end{array}$ & $\begin{array}{l}\text { Horticultural } \\
\text { Services }\end{array}$ & $\begin{array}{l}\text { Wholesale \& } \\
\text { Retail Trade }\end{array}$ \\
\hline Idaho & 853 & 12,000 & 576 & 91 & 164 & 320 \\
\hline Montana & 357 & 5,988 & 219 & 31 & 43 & 145 \\
\hline Nevada & 1,248 & 17,324 & 844 & 13 & 633 & 198 \\
\hline Utah & 901 & 13,577 & 600 & 130 & 206 & 264 \\
\hline Wyoming & 174 & 2,581 & 109 & 4 & 44 & 61 \\
\hline Pacific & 27,502 & 352,485 & 18,382 & 4,905 & 7,927 & $\mathbf{5 , 5 5 0}$ \\
\hline Alaska & 159 & 2,110 & 104 & 10 & 36 & 58 \\
\hline California & 20,362 & 253,977 & 13,656 & 3,165 & 6,429 & 4,063 \\
\hline Hawaii & 745 & 11,166 & 531 & 200 & 220 & 112 \\
\hline Oregon & 3,173 & 43,980 & 2,010 & 1,048 & 448 & 515 \\
\hline Washington & 3,064 & 41,251 & 2,080 & 482 & 795 & 803 \\
\hline Total All Regions & 147,828 & $1,964,339$ & 95,084 & 20,796 & 39,013 & 35,275 \\
\hline
\end{tabular}

* Values expressed in 2004 dollars (GDP Implicit Price Deflator, US Dept. Commerce)

The economic impacts of the urban forestry sector within the Green Industry were evaluated in relation to (1) the production of trees suitable for urban forestry by nurseries, and (2) tree care services provided by the landscape services sector. Based on survey information, the value of tree production suitable for urban forestry, including deciduous, evergreen, fruit, and Christmas trees, was $\$ 4.63 \mathrm{Bn}$. This value represented 27.2 percent of total output by the nursery and greenhouse sector. The value of tree care services was $\$ 9.92 \mathrm{Bn}$, which represented 27.1 percent of the output of the landscaping services sector. The total output of tree production and care services was valued at $\$ 14.55 \mathrm{Bn}$, which translated into $\$ 21.02 \mathrm{Bn}$ in total output impacts, 259,224 jobs, $\$ 14.12 \mathrm{Bn}$ in value added, $\$ 9.93 \mathrm{Bn}$ in labor income, and $\$ 516 \mathrm{Mn}$ in indirect business tax impacts. Trees sold to municipalities for use in urban forest settings (e.g., parks and other recreational areas) also are associated with significant public sector employment.

In addition to these economic impacts of commercial activity within the Green Industry, various studies have shown that urban forests have other non-monetary or non-market economic and environmental impacts, including energy savings for building heating and cooling, reduction of atmospheric carbon dioxide, improved air quality, reduction of stormwater runoff, and other aesthetic benefits. Well landscaped homes with appropriate tree canopy have a 7 to 11 percent premium in value compared to similar properties without such amenities.

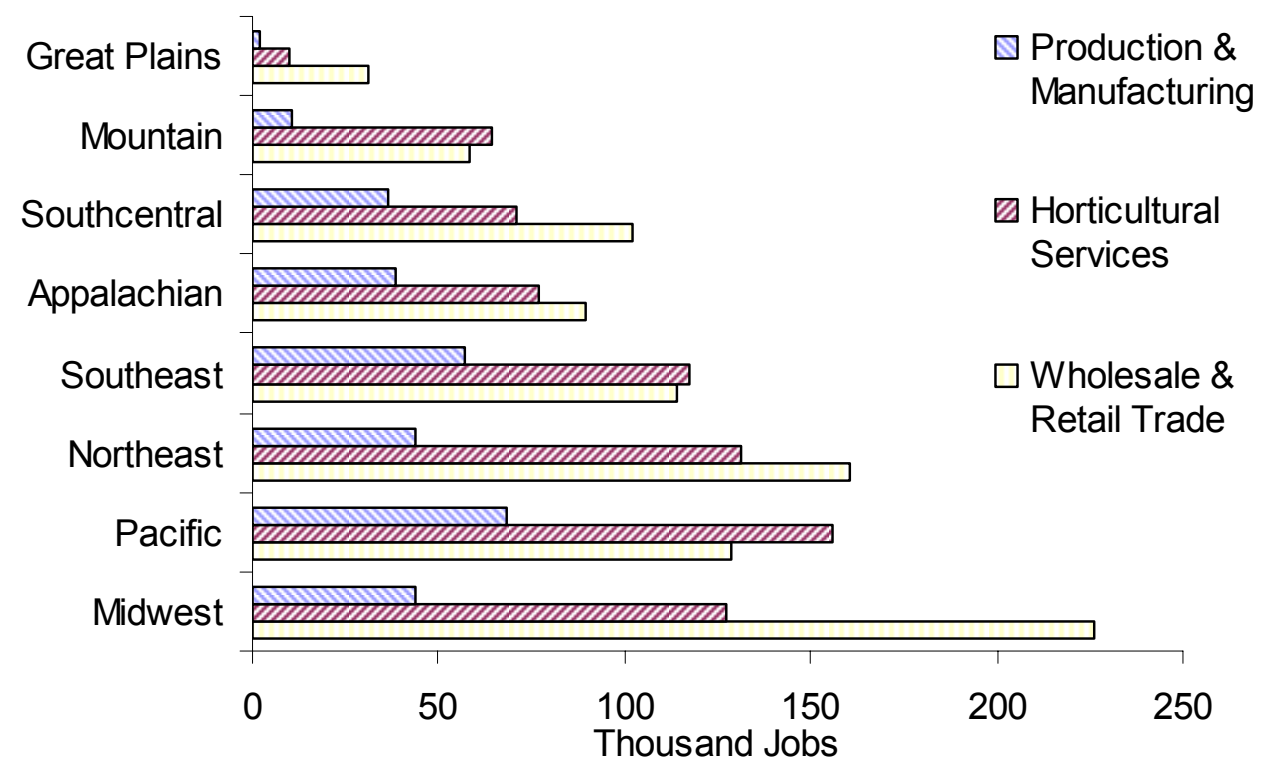

Figure ES-2. Employment Impacts of the U.S. Green Industry, by Region and Industry Group, 2002 


\section{Background and Introduction}

The U.S. environmental horticulture industry, also known as the "Green Industry", is comprised of wholesale nursery and sod growers, landscape architects, designers/builders, contractors and maintenance firms, retail garden centers, home centers and mass merchandisers with lawn and garden departments, and marketing intermediaries such as brokers and horticultural distribution centers (re-wholesalers). This industry is one of the fastest growing sectors in the nation's agricultural economy; often experiencing growth and expansion even during recessionary periods.

The relationship between urban/community forestry and the Green Industry has become more widely recognized as urban forestry has become more acknowledged as an integral segment of the infrastructure of our communities. However, this relationship is still vastly unappreciated in terms of the degree of synergy that the two segments share. Not only is the Green Industry crucial for the support of urban forestry in providing quality plant material used in our cities, it also offers professional personnel with specialized expertise for growing, maintaining, and managing city trees. These professionals have demonstrated their willingness to educate, volunteer, and mentor city employees in the cities and towns where they make their homes and own businesses. Conversely, urban forestry initiatives provide the Green Industry with a strong, dependable, and expanding market in which they can sell their goods and services. Cities can rely on growers to produce the size and species they require, and they can also depend on a professional cadre of landscape contractors and tree care providers to help maintain the resource that a healthy urban or community forest offers to its citizens. Both entities enjoy the benefits of this symbiotic relationship, and each would be diminished without the other. The importance of developing a mechanism by which this relationship can be measured, therefore, is crucial to understanding how to best plan for the future strengthening of each.

In spite of the magnitude and recent growth and interest in the Green Industry, there is surprisingly little information that has been developed on the national level regarding the economic impact of the Green Industry. The USDA does conduct floriculture and nursery crop surveys to collect information at the grower level, but data are often incomplete for some states and grower cash receipts reported do not reflect the further economic impacts generated from this production activity. Census data, including the 10-year Census of Horticultural Specialties, are subject to the same limitations and have historically had other mitigating problems such as poor response rate that reflect poorly on the data's accuracy. For firms downstream in the supply chain, such as landscapers, rewholesalers, and retailers, there are economic statistics and employment data maintained by each state's Office of the Comptroller. However, misclassification errors and non-compliance on the part of industry participants have made some state data speculative at best. There is a transition to a new system (called the North American Industrial Classification System, or NAICS for short) currently underway that should provide more robust estimates in the future. However, to date, no one source of data has proven historically to be instrumental in capturing the total economic importance of the Green Industry.

Recognizing the limitations of existing data sources and also the critical need for this type of economic impact data, several state nursery and landscape associations have sponsored and developed their own economic impact studies for their respective green industries. Such states have found these studies to be useful in communicating the importance of the Green Industry to state legislatures, and in combating proposed legislation that would have had severe negative impacts on urban or community forestry initiatives and the Green Industry (e.g., labor regulations, constraints on water usage, etc.). As useful as these state-specific studies have been, there have not been similar analyses conducted at the national level, which would provide similar benefits on a national scale.

The objective of this study is to estimate the economic impacts of the Green Industry at the national level, synergistically utilizing the studies that have already been conducted by several states, and complementing those with data from other primary and secondary sources. In addition, this study seeks to evaluate the value and role of forest tree species (woody ornamental trees) as a product. The project is funded under the third category of the NUCFAC 2003 Challenge Cost-Share Grant program (Communicating the Value of Urban and Community Forestry) with the research priority of "measuring the national value of goods and services produced by the Green Industry." 


\section{Green Industry Structure}

The Green Industry complex includes input suppliers; production firms such as nursery, greenhouse, and sod growers; wholesales distribution firms, including importers, brokers, re-wholesalers, transporters; horticultural service firms providing landscape and urban forestry services such as design, installation, and maintenance; and retail operations, including independent garden centers, florists, home improvement centers, and mass merchandisers or other chain stores. The United States leads the world in the production and marketing of floriculture and nursery crops.

\section{INPUT SUPPLY FIRMS}

Input supply firms, often referred to as allied trade firms, are businesses that provide various inputs for ornamental plant production, landscape services, and retail sales. These inputs commonly include agrichemicals, fertilizers, containers, packaging, farm machinery, tools and equipment, propagative materials, and consulting services. These products originate from extractive and manufacturing industries such as mining, petroleum, and forestry.

\section{ProduCTION FIRMS}

Participants engaged in producing Green Industry products include growers of floriculture crops, nursery crops, and turfgrass sod. Floriculture crops include bedding plants, potted flowering plants, foliage plants, cut cultivated greens, and cut flowers. As distinguished from nursery crops, floriculture crops are generally herbaceous. Bedding and garden plants consist of young flowering plants (annuals and perennials) and vegetable plants. They are grown in flats, trays, pots, or hanging baskets, usually inside a controlled greenhouse environment, and sold largely for gardens and landscaping.

Potted flowering plants are largely sold in pots for indoor use. The major potted flowering plants are poinsettias, orchids, florist chrysanthemums, and finished florist azaleas. Foliage plants are also sold in pots and hanging baskets for indoor and patio use, including larger specimens for office, hotel, and restaurant interiors. Cut flowers are usually sold in bunches or as bouquets with cut foliage. The most popular cut flowers are roses, carnations, gladioli, and chrysanthemums. Leatherleaf ferns are the leading cut foliage. Combining cut flowers and cut greens in bouquets or other flower arrangements is a value-added retail option.

The market outlets for floriculture crops are florists, garden centers, mass merchandisers, supermarkets, chain stores, discount stores, home improvement centers, hardware stores, landscape contractors, and re-wholesalers. Other retail outlets are farmers markets, flea markets, and street vendors. Since cut flowers are perishable and live floral crops are sensitive to variations in temperature, they usually require cool transportation and storage conditions that preserve and prolong their quality before final sale. The demand for floral crops, especially cut flowers, is highly seasonal. Sales are normally highest from February through May and in the fall. Sales of cut flowers peak during holidays such as Valentine's Day and Mother's Day. Poinsettia plants are sold mostly from Thanksgiving to Christmas. Cut flowers and foliage plants, however, are increasingly popular throughout the year as indoor home and workplace decorations.

Nursery crops are woody perennial plants that are usually grown in containers or in-ground. The Census of Agriculture defines nursery crops as ornamental trees and shrubs, fruit and nut trees (for noncommercial use), vines, and ground covers. They are primarily used for landscaping, not for producing edible products on a commercial scale. Trees and shrubs are classified as deciduous or evergreen. Deciduous includes shade, flowering, ornamental, fruit, and nut trees and shrubs. Evergreens include broadleaf and coniferous trees, and Christmas trees.

The location of nursery production is determined largely by soil, climate, availability of water, accessibility and distance to markets, and cost of land. Each plant species has a hardiness zone that sets the northern geographic latitude for in-ground growth. Trees and shrubs start out as "liners" (undeveloped, but rooted, trees and plants in pots or trays). As seedlings, they are typically protected from intense sunlight or severe weather by shade or temporary cover. The next step is transplantation into larger containers or the field for further growth. Sales can occur at any stage depending on the plants' commercial purpose. 
Growers plant bare-root material ("liners") in rows in the field, either in the fall, giving the roots time to develop before the plant breaks dormancy, or in the spring. Broadleaf shrubs and trees (holly, oak, and magnolia, for example) are often purchased as small container-grown liners, which are more expensive than bare-root plants because fewer die after transplanting. Liner production requires 6-12 months for the roots to develop and the plant to reach the size needed for planting in the field. Bare-root material, the most economical nursery stock, is best planted in the early spring before growth begins.

Since nursery crops are usually grown in the field or in containers often without covered protection, the choice of crops is based on an area's natural vegetative species or the crop's ability to tolerate local climatic conditions. Thus, sales of most nursery crops, except Christmas trees, are more local or regional than floriculture crops, which are less costly to ship to farther markets. While homeowners are the typical consumers of trees, shrubs, and woody ornamental plants, markets also include developers, public utilities, golf courses, resorts, commercial parks, malls, as well as government agencies in charge of public parks, street and highway vegetation, and forests. Like many floral crops, demand for nursery crops (except Christmas trees) tends to coincide with normal planting seasons in the spring and fall.

Wholesale sales of nursery products are usually handled by salespersons who have established relations with large buyers. Marketing programs include numerous trade shows, advertising in trade publications, catalogs, and direct mail. Close planning with large buyers (referred to as partnering) is required to secure long-term markets and to ensure that the right product mix is produced; however, demand for different products can still vary substantially from year to year. Sales and many variable expenses (costs-of-goods-sold) are highly seasonal, with up to 50 percent of sales in the second quarter of a typical year. Cash flow is uneven throughout the year so cash management is important. Technical knowledge of plants and pests is important for nursery management, although many of the everyday tasks (cultural practices) are routine and do not require specialized labor. However, automation has proven to be difficult, aside from the widespread use of irrigation and fertilization systems. Greenhouse operations can be very sophisticated, with automatic irrigation and fertilization (sometimes referred to as fertigation), and air and lighting systems driven by a variety of sensors. Innovations demanded by big-box retailers (such as custom labeling, bar codes, scanners, and electronic data interchange between suppliers and buyers) are now used by many producers.

In recent years, there has been considerable consolidation among large growers, largely in response to consolidation occurring at the retail level. The rise of large, nationwide plant retailers like home centers and mass merchandisers has created a marketing opportunity for large growers who can supply the large volumes these customers require. Some nursery firms have grown rapidly through acquisition during the past decade, largely to service these big customers. Geared to serve big customers by handling large volumes, large growers actively discourage small-volume buyers. The big-box retailers and large landscape installation companies are supplied mainly by large nurseries, while independent garden centers, retail nurseries, and smaller landscape firms may be supplied by both large and small growers. Proximity and high product quality are more important to these buyers than low price because the end consumer is most interested in quality and the breadth of retail selection. Keeping plants alive and healthy is a challenge for many consumers, and small retail operations often have more technically knowledgeable staff than mass retailers to assist customers with plant care advice.

To even out the seasonal nature of demand throughout the year, many nurseries produce plants like Easter lilies and poinsettias that have demand at times other than late spring or fall. Large producers may also sell related products like soil, sod, and Christmas trees. Some growers may produce a range of soil mixtures made from peat moss, sand, bark, sawdust, lime, perlite, vermiculite, and other materials (including mulched product waste) to sell to other growers on a contract basis.

Turfgrass sod farms are specialized nurseries that usually only produce a subset of turfgrass varieties that are hardy for their particular region. Once sod leaves the nursery/farm, it usually passes through one or more marketing channels and is eventually used for new residential or commercial developments, for re-landscaping existing developments, for sports turf facilities such as athletic fields and golf courses, or for commercial applications that include businesses, public and private schools, and roadside uses. The final customer for sod can be the homeowner, a golf course, or an elementary school. Each of them has different circumstances and, hence, 
different expectations. Thus, sod producers take these different needs into account. Although the customer generally decides the type of sod to purchase, the installer also plays an important role. Both the landscape contractor and sod installer often make the decision from whom to buy and may even recommend to the homeowner the type of sod to plant. Hence, although both the final consumer and the middleman are important, the latter is critical from the sod producers' perspective.

\section{WHOLESALE DiSTRIBUTION FIRMS}

Wholesale distributors are an integral part of the Green Industry supply chain. Intermediaries such as brokers and importers facilitate the transactions of domestic and international (importing/exporting) growers and retailers. Rewholesalers (often referred to as horticultural distribution centers, HDCs, or landscape distribution centers) are also market facilitators that offer regionally specific mixes of landscape products for immediate pickup or delivery to landscape professionals and have emerged throughout the United States in a variety of forms. There are self-contained HDCs and HDCs that serve as independent profit centers within vertically-integrated grower, landscape contracting, and retail garden center operations. Landscape distribution traces its development back to the produce dealers of the 1940s and 1950s. Following World War II, a sustained building boom fueled an increasing demand for products and services that landscape professionals, retail garden centers, and other horticultural businesses attempted to fulfill. At the same time, rising land values pushed the growers farther away from the spreading urban and suburban areas where the most demand existed. The resulting longer supply lines created difficulties in meeting the expanding needs of the horticulture industry. This spawned development of this new distribution network from the nursery grower to the horticultural customer.

The long-distance distribution system infrastructure for plants is still being refined in many parts of the country. An efficient trucking system extends from Florida all along the East coast, featuring regular routes run by independent trucking companies. Some large producers have developed in-house, large-volume delivery systems to service big-box retailers. But cross-country shipments are still difficult because of the long time that plants are in trucks, lack of back haul opportunities, and the excessive handling that takes place for small orders. Air transportation is being used more frequently, but only for high-value plants (e.g., cut flowers).

\section{Horticultural SERViCe Firms}

Horticultural service firms include those firms that provide a plethora of design (architectural) services, installation (construction) services, and maintenance services. These firms serve a variety of clientele, including residential homeowners, commercial business properties, and municipalities. Some firms in the industry offer a combination of design, installation, and maintenance services (e.g., design-build firms) to appeal to a larger clientele base. However, other businesses gear their services towards specific markets. For instance, some specialize in seeding and fertilizing areas along newly constructed highways and installing or constructing erosion control devices. Such work is usually contracted from state departments of transportation or subcontracted from state highway contractors working on federally funded projects. Local governments also use these services.

Landscape design or architectural establishments are primarily engaged in planning and designing the development of land areas for projects, such as parks and other recreational areas, airports, highways, hospitals, schools, land subdivisions, and commercial, industrial, and residential areas, by applying knowledge of land characteristics, location of buildings and structures, use of land areas, and design of landscape projects.

Landscape contracting or installation establishments are primarily engaged in installing trees, shrubs, plants, lawns, or gardens, and the construction of walkways, retaining walls, decks, fences, ponds, and other similar (hardscape) structures. Specialized installation services such as irrigation systems, water features, night lighting, and Christmas decorations are becoming more prevalent.

Landscape maintenance establishments include firms that provide services such as mowing, trimming, leaf or snow removal, tree removal or trimming, mulching, and other garden and lawncare services. Lawncare services are defined more narrowly as services devoted to lawn "treatments" as opposed to the other "maintenance" activities listed. The difference is that treatment primarily involves applying fertilizers and pesticides to lawns, with the goal being to maximize lawn appearance and health while minimizing effort on the part of the client. The prime selling points of these service firms are that they have the knowledge and expertise to diagnose problems and apply lawn chemicals properly, effectively, and safely; they have the proper equipment to do the job; and they provide the materials, thus eliminating the need for homeowners to store toxic chemicals on residential 
premises. Besides offering basic services, many lawncare firms also offer customized programs which often include lawn aeration, dethatching, resodding and/or overseeding, and integrated pest management.

\section{RETAILERS}

Retail firms are another point of contact with end consumers of horticultural products, such as independent garden centers, florists, home centers, mass merchants, and other chain stores. Garden centers are establishments primarily engaged in selling trees, shrubs, other plants, seeds, bulbs, mulches, soil conditioners, fertilizers, pesticides, garden tools, and other garden supplies to the general public. These establishments primarily sell products purchased from others, but may sell some plants which they grow themselves. Garden center consumer studies indicate customer loyalty and repeat business result from a convenient store location, plant quality, customer service, and plant selection. According to the latest National Gardening Survey, the number of households that purchased lawn and garden products at selected retail outlets in 2003 is outlined below:

\section{Table 1-1. U.S. Households Purchasing Lawn and Garden Products, By Type of Outlet, 2003}

\begin{tabular}{lcc} 
Type of Retail Outlet & $\begin{array}{c}\text { Number of } \\
\text { Households } \\
\text { (Millions) }\end{array}$ & $\begin{array}{c}\text { Share of } \\
\text { Households } \\
(\%)\end{array}$ \\
\hline Home Center & 45 & $53 \%$ \\
Independent Garden Center & 36 & $43 \%$ \\
Mass Merchandiser & 34 & $41 \%$ \\
Hardware Store & 25 & $30 \%$ \\
Supermarket/Drug Store & 16 & $19 \%$ \\
Feed/Seed Store & 10 & $12 \%$ \\
Mail Order/Internet & 6 & $7 \%$ \\
\hline
\end{tabular}

\section{END USERS}

Final consumers of Green Industry products and services are referred to as end users. While the vast majority of nursery and turfgrass products used by end users are purchased from Green Industry businesses, this is not the case for services. A significant amount of lawn and landscape services are performed by the end users themselves. However, these services are only for internal consumption; that is, end users do not maintain or care for any landscape plants or green space other than their own.

The list of end users includes airports, cemeteries, churches, commercial general business areas, golf courses and driving ranges, homeowners, municipalities, private recreation areas, public roadways, schools and universities, and utilities. "Commercial areas" are comprised of restaurants, banks, credit unions, commercial building operators, shopping centers, real estate managers, apartment buildings, other dwelling operators, mobile home sites, hotels and motels, medical centers, nursing care centers, intermediate care facilities, general and specialty hospitals, residential care facilities, retirement communities, community centers, and adult and child day-care centers. City park districts, arboretums and zoos, city streets, and other urban public areas are maintained by municipalities. Public roadways encompass both state and county roadsides and highways.

The National Gardening Association is a well known and widely recognized authority on the consumer lawn and garden market in the United States. Since 1973, NGA has worked with the Gallup Organization (and now with Harris Interactive, Inc.) to provide market research information for the lawn, garden, and nursery industries. Some highlights of the latest NGA survey include:

- Eight out of ten U.S. households (78\%), or 84 million households, participated in one or more types of do-it-yourself indoor and outdoor lawn and garden activities in 2003. That is about the same number seen in 2002, and one of the highest levels of participation seen in the past five years.

- Consumers spent an average of $\$ 457$ per household on their lawns and gardens in 2003. Over the past five years, annual spending has averaged $\$ 465$. USDA/ERS reports average household expenditures in 2003 on nursery and floral plants alone at $\$ 140$ per household.

- Consumers spent a total of $\$ 38.4$ billion on their lawns and gardens in 2003. That was about the same level of spending seen over last three years. Over the past five years, total lawn and garden sales have 
increased at a compound annual growth rate of 5 percent, from $\$ 30.2$ billion in 1998 to $\$ 38.4$ billion in 2003.

- The most important consumers of lawn and garden products last year were men; people age 45 and older; college graduates; households with no children at home; households in the Northeast, South, and West; married households; 2-person households; and households with annual incomes over \$75,000.

\section{Current Green Industry Situation}

Long term growth in output of the principal sectors of the US Green Industry is charted in constant dollar terms for the period 1987 to 2003 in Figure 1-2. Information on the landscape services and retail sectors was available only through 2001, due to the changeover to the NAICS system. It is evident that the sales output of the landscape services sector has grown dramatically, from around $\$ 15 \mathrm{Bn}$ in 1987 to nearly $\$ 40 \mathrm{Bn}$ in 2001, representing an average annual growth rate of 11.0 percent. The retail nurseries and garden stores sector also grew significantly, although at a lower level, from $\$ 3.7$ to $\$ 6.2 \mathrm{Bn}$ as gross margin on sales, averaging 5.0 percent annual growth. The nursery and greenhouse sector grew in real terms from $\$ 10.7 \mathrm{Bn}$ to $\$ 14.7 \mathrm{Bn}$ in 2003, or at a 2.4 percent average annual rate. The lawn and garden equipment manufacturing sector actually declined in value from $\$ 8.3$ to \$7.1 Bn between 1998 and 2003, a -2.7 percent annual rate.

\section{NURSERY AND GREENHOUSE GROWERS}

Although grower receipts from greenhouse and nursery crops are expected to be up by less than 1 percent in 2004, they still represent another year of an unbroken series of annual sales increases. Sales of floriculture crops are also projected to be up slightly following a small decline in 2003 (USDA, NASS). Among floriculture product groups, cut flowers, potted flowering plants, and cut cultivated greens experienced reduced sales in 2003, largely due to competition from imports, and sales are projected to be down again in 2004 even as most prices continue upward. Bedding and garden annual and perennial plants and propagative materials are the only floriculture crops whose sales are expected to be higher in 2004. Nursery crops are also forecasted to extend annual sales gains into 2004, in part because of still-robust new housing construction.

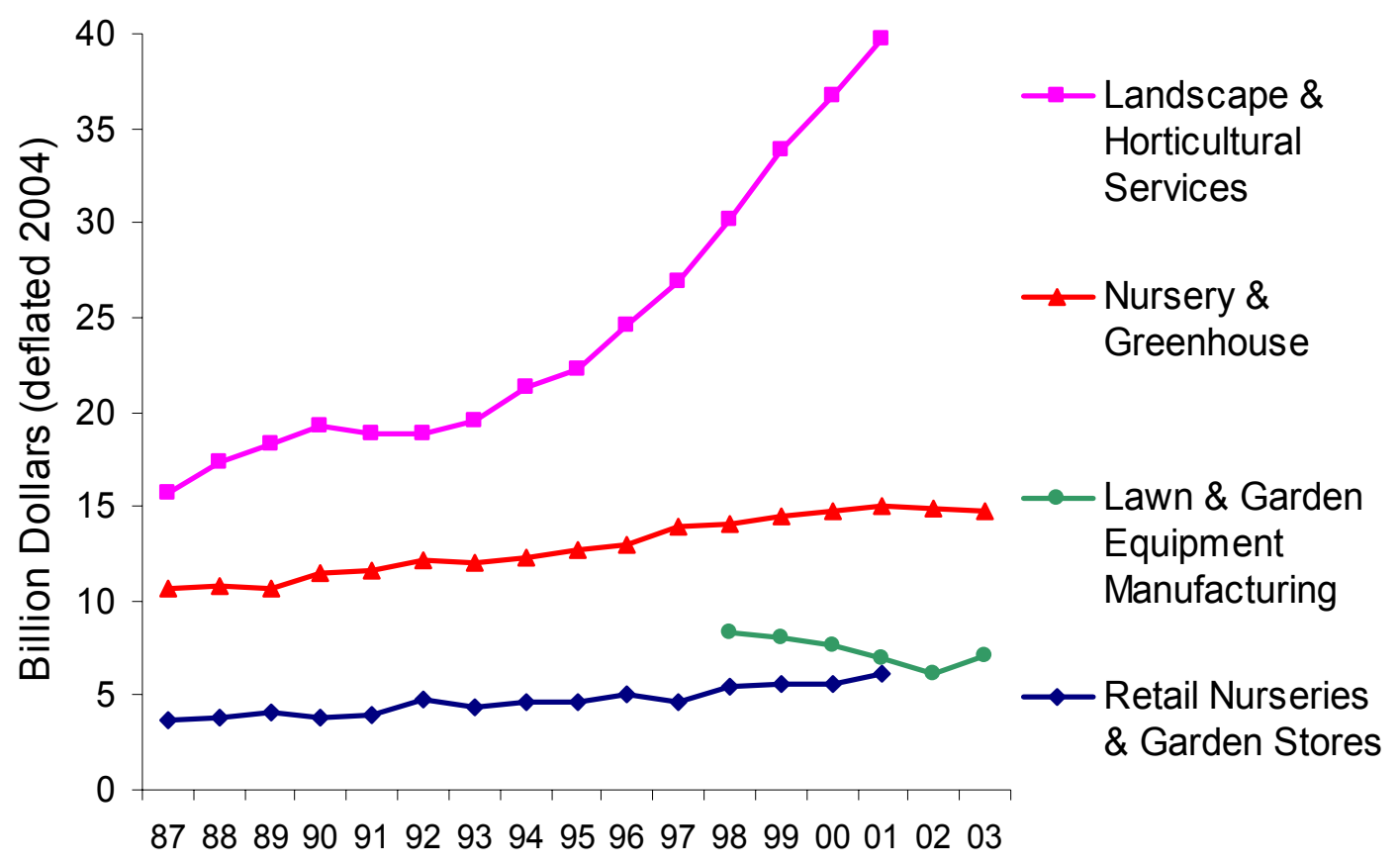

Figure 1-1. Growth in Output of US Green Industry Sectors, 1987-2003. Values expressed in constant 2004 dollars using GDP Implicit Price Deflator (USDOC). Data Sources: USDOC/BEA; USDA/ERS (nursery \& greenhouse). 
An important reason that nursery crop sales remained healthy in 2003, compared with floriculture crops, is the lower share of imports in nursery crop consumption. Relentless competition from imported cut flowers from South America has reduced domestic growers' U.S. market share to minority status. Per-household consumption of greenhouse and nursery crops of \$139 in 2004 represents the second year of decline since its peak in 2002, matching the pattern of floriculture crops. Nevertheless, the ornamental crop sector will post total sales in excess of $\$ 15.3$ billion in 2004 , a value exceeded only by corn, soybeans, and vegetables among agricultural crops nationwide.

Sales of floriculture crops were projected to grow to $\$ 5.1$ billion in 2004 , due largely to gains from bedding and garden plants which represent 48 percent of total floriculture sales. Sales of bedding and garden annuals and herbaceous perennials are forecast to increase 1 percent. This contrasts with declines in cut flowers, potted flowering and foliage plants, and cut cultivated greens as competing imports provide further incentives for growers to produce other higher value and specialty crops. However, outsourcing cuttings and seedling production to lower-cost growers in Central America and Mexico is one way that domestic producers are coping.

Besides the top three producers of ornamental crops - California, Florida, and Texas - North Carolina and Oregon are close to reaching $\$ 1$ billion in annual sales. Both of these States produce about $\$ 800$ million worth of nursery and other greenhouse crops and only between $\$ 100$ and $\$ 200$ million of floriculture crops. Emerging competitors are Michigan and Ohio, which, by contrast, produced between $\$ 200$ and $\$ 400$ million of floriculture crops in 2003. These Midwestern States are leading producers of bedding and garden plants, both annuals and perennials, in large part due to increased greenhouse production. Michigan and Ohio are not far behind Texas in total greenhouse acreage. While Florida remains the predominant supplier of indoor foliage plants east of the Mississippi River, upcoming suppliers include North Carolina, Ohio, and Louisiana.

Together with bedding and garden plants, nursery and other greenhouse crops are the only agricultural product groups expected to continue gains in per-U.S.-household sales. Their higher sales in 2004 more than offset the declines in the other groups. Including Christmas trees, greenhouse vegetables, vegetable transplants, and sod, sales of nursery and other greenhouse crops have continuously grown historically but have slowed in recent years in terms of per-U.S.-household sales at around $\$ 93$ since 2002. Given that this sector accounts for two-thirds of total greenhouse and nursery crop receipts, it is largely responsible for keeping per-household sales of ornamentals and other greenhouse crops at about $\$ 139$ in recent years.

While the projected increase in floriculture growers' sales in 2004 is modest, average annual sales per grower is expected to continue rising beyond $\$ 1$ million. As grower sales expand, either total production area also expands or sales per acre increases. In 2003, total U.S. floriculture production area increased largely due to Texas adding 10 times more space of open field production. Despite growth in open field production, average covered production area per large grower rose 3 percent to 4 acres, up from 3.9 in 2002 . After climbing in 2002, the number of growers with at least $\$ 100,000$ in annual floriculture sales fell from 4,974 to 4,741 in 2003 . The addition of significant open field production area by growers pushed total production acres to 57,507 acres in 2003, up from 52,235 in 2002. However, since total production acreage grew faster than floriculture sales, average sales per acre dropped 9 percent, from $\$ 91,000$ to $\$ 83,000$, in 2003 . Floriculture sales per production acre are still highest in the Midwestern States at $\$ 126,000$. Growers in Minnesota lead the region at almost \$230,000 sales per acre. Nevertheless, the largest growers based on floral sales are in the West-average sales per grower in California now exceed \$1.8 million. While Southern States trail the West at $\$ 1.1$ million sales, average sales per grower in South Carolina tops the country at $\$ 2.5$ million sales per grower, dwarfing California's average. South Carolina is the biggest producer of herbaceous perennial plants, selling 12 percent of total U.S. production.

After slipping in 2002, U.S. cut flower imports surged 13 percent to $\$ 611$ million in 2003, and are expected to continue to grow in 2004 (USDA, NASS). As a result, sales of domestically produced U.S. cut flowers are forecast down 1 percent in 2004, but consumer prices for flowers and indoor plants are up 18 percent from 2003. Cut flower production in California, which accounts for 70 percent of U.S. production, is at best flat in 2004, even in view of higher prices. The projected decline in volume of domestic cut flowers sold in 2004 is cushioned to some extent by somewhat higher prices. Overall sales of $\$ 421$ million in 2004 are down 1 percent from 2003. As a result, sales per U.S. household fell to $\$ 3.83$, almost a whole dollar lower than in 1997. By contrast, cut flower imports per U.S. household are almost \$6, matching 1998's level. Cut flowers comprise half of total U.S. 
floriculture and nursery stock imports. The share of imported cut flowers in total U.S. cut flower supply was 56 percent as recently as 2002. It is anticipated to jump to 63 percent in 2004. The number of cut flower producers in the United States was at a record low of 548 in 2003, down from 618 in 2002, and is expected to dwindle further. Despite fewer producers, average cut flower sales per U.S. grower have been growing and now approach $\$ 780,000$ as the size of operations has expanded. By rank order, the largest average sales of growers are of roses (\$701,000); gladioli, gerbera daisies, lilies (all around \$500 million); and tulips and chrysanthemums (both about $\$ 300$ million). In average unit prices, the leaders are pompon mums at $\$ 1.32$ per bunch, orchids at $\$ 0.70$ per bloom, and lilies at $\$ 0.64$ per stem.

Sales of potted flowering plants are forecast at $\$ 820$ million and foliage plants at $\$ 616$ million in 2004, down slightly from $\$ 829$ million and $\$ 623$ million, respectively, in 2003 (USDA, NASS). Competition from fastgrowing imports, especially from Canada, and crop damage from hurricanes in Florida will dampen sales prospects of domestic growers. Imports of orchid plants are also rising from Taiwan, Thailand, the Netherlands, South Korea, and Canada. Nevertheless, domestic grower sales of potted flowering plants per U.S. household have held steady at between $\$ 7$ and $\$ 8$, and between $\$ 5$ and $\$ 6$ for foliage plants, over the past decade. Florida dominates the foliage plant market, capturing 64 percent of total U.S. value in 2003. Prices of potted flowering plants have risen 6 percent on average since 2000, reflecting healthy demand for high-value varieties such as florist roses, florist azaleas, and spring flowering bulbs. Even prices of poinsettias, which account for 30 percent of total receipts from potted flowering plants in 2003, were up in the last two years. Prices of potted orchids, however, appear to be in a downward trend since 2000 . The quantity of potted orchids sold jumped from 9.7 million in 2000 to 15.6 million in 2003, indicating increasing supply. Although producers boosted domestic orchid production, imported orchid plants have grown 70 percent in volume since 2000, providing ample competition to local growers.

Bedding and garden annuals dominate U.S. floriculture sales, comprising 36 percent of the $\$ 5.1$ billion sales of floral crops in 2003 (UDA-NASS). Together with herbaceous perennial plants, the share is boosted to 48 percent. And since this sector posted a 1-percent sales gain in 2003, compared with declines in cut flowers, potted flowering plants, and cut cultivated greens, it was enough to push total floriculture receipts up. This growth is expected to repeat in 2004 as total bedding and garden receipts reach at least $\$ 2.424$ billion, up \$23 million from 2003. Sales of bedding and garden annuals are forecasted at $\$ 1.823$ billion in 2004 , continuing annual gains since 2000. Herbaceous perennial sales are also projected up, exceeding sales of foliage plants for the first time and becoming the second largest segment/product group in the industry. It is evident that growers are increasing production of annuals and perennials relative to other floriculture crops, more significantly in the Midwest and Northeast. Sales of annuals in flats were down in 2003 while potted annuals and hanging baskets registered gains. Although floriculture sales per U.S. household will continue to decline, albeit marginally, per household sales of bedding and garden plants are expected to remain at just over $\$ 22$, unchanged since 2002. Prices of bedding and garden plants have been noticeably stable since 2000 as sales growth is matched by the pace of quantity produced. This price pattern is the effective average between weak prices of annuals and rising prices of perennials since 2001. For annuals, prices of potted plants and hanging baskets show a slight upward slope in contrast to downward prices of bedding and garden plants in flats. Increased production of bedding and garden annuals in the Midwest is supported by higher overall prices. But production of herbaceous perennials, except potted hardy/garden mums, is shifting heavily to Southern States, specifically South Carolina.

\section{U.S. ORNAMENTAL IMPORTS}

Expected prices for imported cut flowers are up 10 percent, due in part to the weaker U.S. dollar and higher fuel costs for transport (USDA-NASS). U.S.-grown cut flower prices are up 3 percent, due also in part to higher fuel and energy costs and damage to cut flower production by hurricanes in late summer. Import prices of cut flowers in 2004 are 15 percent higher than in 2000, after initially dropping 5 percent in 2002. Cut flower imports fell in 2001 and 2002 due to weak U.S. demand which was precipitated by the economic recession and stock market downturn. The share of imports in U.S. cut flower consumption is projected at a record 65 percent, up from 61 percent in 2003. In 1992, the import share was 20 points lower at 45 percent. The quantity of imported flowering and bedding plants, largely from Canada, are expected to be up 8 percent in 2004 based on strong shipments from January to July. However, lower prices for imported flowering, bedding, and foliage plants push the import value down somewhat from 2003. Ninety-four percent of U.S. imported cut flowers are from Colombia, Ecuador, the Netherlands, Mexico, Canada, and Costa Rica. Cut flower imports are dominated by roses at 35 percent of 
imports, chrysanthemums at 11 percent, and carnations at 10 percent. Imports of flowering plants from Asia, such as orchids, and nursery plants and trees from Canada limit wholesale prices that domestic growers of these products can charge without losing market share. These help explain in part why wholesale prices of U.S.-grown potted flowering plants and bedding and garden plants have been generally flat since 2000. But for growers in the Midwestern and Eastern States, prices have improved relative to some growers in the South and especially in contrast to growers in the West.

\section{LAWN AND GARDEN EQUIPMENT}

U.S. demand for power lawn and garden equipment is projected to rise over 3 percent per year through 2009, reaching \$10.7 billion, according to a new study by the Freedonia Group. An expansion of the key 55-64 year-old age group will contribute to gains, the report says, as this group typically trades up from older, less expensive equipment to higher-end products, or increasingly engages professional lawn care services. Growth will also result from product innovations and upgrades, driven by consumer demand for equipment with increased horsepower, additional features and lighter weight. The continued popularity of golf will also present opportunities, as a growing number of golf courses compete to have the best playing surfaces.

The residential market dominates power lawn and garden equipment sales, representing approximately two-thirds of the total in 2004. However, advances in the commercial market have outpaced the residential market in recent years, bolstered by the tremendous growth in the sales of zero-turn radius turf mowers. In addition, the continuing rise in the number of professional landscapers (in part a byproduct of an aging population) has boosted commercial demand. Although gas-powered equipment will remain dominant, electric-powered products are expected to post significantly stronger gains through 2009. Battery-powered equipment will fare particularly well, as improved battery technology is introduced. Cordless products are easy to use and have a better environmental image than competitive products. In addition, they appeal to women, who account for a growing portion of equipment sales and use.

Lawnmowers will continue to be the largest product segment, benefiting from their wide use in both residential and commercial applications. Turf and grounds equipment is expected to post the best gains, because of continuing growth in the professional landscaping services industry and the rising number of golf courses. Despite the improving durability of original equipment, parts and accessories will outpace the industry average due to the rising amount of stock in use.

\section{Horticultural SERVICE FIRMS}

Landscape-related firms surveyed in August 2004 by Lawn \& Landscape magazine said that 2004 business revenue is up an average of 17.4 percent, individual service sales have increased in all categories, and net profits are projected to rise. Contributing to the industry's sound standing is an increase in consumer spending and a healthy housing market. Overall, 2004 represented encouraging economic times for the Green Industry. In contrast to previous annual surveys, contractors say their 2004/2005 concerns have shifted from matters such as finding adequate labor to cost-based concerns such as escalating health insurance and workers' compensation rates, as well as increased fuel expenses. Many contractors are focusing on raising business efficiency to combat these costs. Landscape companies are younger today, with the average age being 13.6 years old in 2004 versus 17.7 years old in 1999. In fact, a greater percentage of contractors - 28 percent - have been in business less than five years, compared to 12 percent in 2000, 15 percent in 2001 and 17 percent in 2003. Landscape companies that have operated more than five years include 23 percent who have been in business five to nine years, 25 percent who have been in business 10 to 15 years, and 24 percent who have been in business more than 20 years. Despite the fact that these companies are younger, they are generating more revenue, on average, today at $\$ 732,353$, compared to $\$ 694,300$ in 2002 .

In terms of growth, the percentage of contractors who said their total gross sales revenue would increase in 2004 surpassed the percentage who felt this way in previous years. For instance, 84 percent of contractors said their 2004 revenue would increase compared to 57 percent in 2003 or 59 percent in 2002. In fact, going back to 1997, the percentage of contractors predicting growth for a single year has never been higher than in 2004 . The next closest percentage of contractors foreseeing growth was 72 percent in 1998. Contractors predicted an increase of net 17.4 percent this year. This is up from last year's 13 percent, but down when compared to the rates 
experienced five years ago. For instance, contractors averaged 24 percent growth in 1998 and 19 percent growth in 1999.

Today's typical landscape contractor offers a wider array of services than in the past. Historically, lawn maintenance has represented the greatest total revenue for landscape businesses. Almost 33 percent of contractors said construction generated their greatest total revenue in 2004. This was fairly consistent but slightly higher than in previous years. In 1997, 30 percent of contractors claimed construction generated more revenue and, in 1998, 27 percent said it was their top revenue source. In contrast, fewer contractors claim that chemical lawn care or arborist services generate a majority of their sales than in years past. This year, 10 percent of contractors said chemical lawn care was their most profitable service, while 11 and 14 percent of contractors reported this in 1997 and 1998, respectively. Only 2 percent of contractors said arborist services represented their greatest revenue source, compared to 8 percent in 1997 and 7 percent in 1998.

Nearly half of landscape businesses - 49 percent - said they have become more diverse in the past two years, offering a greater number of services, while 16 percent said they have become more specialized. Thirty-five percent of contractors reported no change in their service structure. Considering the two primary services for a landscape business - lawn maintenance and construction - Lawn \& Landscape broke down the research to find out what other services typical mowing and design/build companies offer. For instance, 59 percent of the companies who primarily mow also offer construction services, 24 percent also offer chemical lawn care, and 53 percent also offer arborist services. Among firms identifying themselves as primarily construction companies, 63 percent also offer lawn maintenance, 23 percent offer chemical lawn care services and 70.6 percent offer arborist services. In terms of 2004 service growth, all areas are experiencing growth. Lawn maintenance is up 15 percent, construction is up 11 percent, chemical/fertilizer services are up 9 percent, irrigation is up 5 percent, snow and ice control services are up 3 percent, arbor services are up 2 percent, and nursery/retail services are up 1 percent.

\section{Green Industry Outlook}

Green Industry participants are facing both challenges and opportunities in today's marketplace. While plant breeders have provided new varieties at a dramatic pace in recent years, which has helped to keep the consumer interested in the industry's products, the demands of retailers are probably having a greater influence in shaping the marketplace for all of those in the market channel, with the possible exception of the consumer. Indeed, retailers are competing for market share and, in their efforts, they are changing the picture of horticulture as seen by both the consumer to whom they sell and the producers from whom they buy.

At the consumer level, the marketplace can best be viewed as divided between so-called "traditional retailers" and mass marketers. Traditional retailers or "independents" would include retail florists, who tend to focus on cut flowers and cut flower arrangements for special occasions, and garden centers, which, in addition to their traditional inventories of trees and shrubs and, in recent decades, bedding and garden plants, are increasingly carrying more and more potted flowering and foliage plants.

On the mass market side of the ledger, supermarkets have become the primary vendors of everyday cut flowers for the home, as well as for potted flowering plants. Increasingly, supermarkets are being viewed as vendors of holiday flowers and plants purchased for gifts. Some supermarkets carry foliage plants quite regularly, and some, in selected markets, have started to sell bedding/garden plants seasonally. Another mass marketer type would be the discount store; these retailers tend to focus on bedding and garden plants in the spring and potted flowering plants for Easter and Christmas. Some also include foliage plants in their offerings. In cases where these retailers have added perishable groceries to their mix (e.g. Wal-Mart SuperCenters and Super Kmarts), they have also added cut flowers as part of the retail format. Target, which had been very involved seasonally in the bedding/garden plant market throughout the country, has reduced this involvement to Florida, California, and selected other southwestern states, where there is more of a year-round market and where they have built permanent garden centers alongside their stores. Nationally, Target maintains a small foliage plant display in most stores, and they carry blooming holiday plants for Easter and Christmas. 
The other dominant mass marketer type is the home improvement/hardware/home center, dominated by Home Depot and Lowe's. These retailers focus on bedding and garden plants to accompany their lines of trees and shrubs and lawn and garden hard goods (garden tools, fertilizers and chemicals, lawn mowers, hoses, and sprinklers, etc.), but they also carry both potted flowering and foliage plants on a weekly basis in established garden departments. At Easter and Christmas, these retailers also display racks of lilies and poinsettias throughout their stores.

\section{CONSUMER TRENDS}

Consumers are very divided by the various retail opportunities for nursery and floricultural products. First, it must be noted that there are very few retailers that can carry a mix that is representative of all of the major industry segments (nursery crops, cut flowers, potted flowering plants, foliage plants, and bedding/garden plants). Hence, many consumers are forced to shop among several retailer types to see the full array of product opportunities. Second, retailers vary dramatically in the selection offered, as well as the qualities, quantities, and sizes in the products and services they provide. Hence, if consumers have particular needs in mind, they may be forced to shop around to find their ideal retail offering. Of course, pricing varies among the retailers, as well.

Working on the side of many retailers is the overall lack of knowledge by the majority of consumers about the industry's products. For mass marketers, the lack of knowledge by the average lawn and garden consumer makes retailing a generic selection of dominant varieties and colors quite acceptable, especially if the retailer is able to attract consumers through the lowest price. For the traditional retailer able to attract the flower or plant aficionado through better quality, wider selection, or better service, the niche opportunities provide their raison d'être. Yet, consumers increasingly report that if they know what they want and they are looking for the bread-and-butter staples, they can get a great deal by buying at mass marketers.

\section{Producer Challenges}

The evolving marketplace has certain challenges for the grower. In many instances, buyers for mass marketers have added what must be considered artificial conditions to the buying arrangements. Some buyers have added "pseudo grades and standards" to plants based on shelving heights or personal preferences, rather than based on generally accepted plant-to-pot ratios; sometimes these conditions are set only to allow the retailer to better exhibit various differences among groups of plants being sold at different price points. Premium versus promotional plants being sold side-by-side provides an example. Ironically, such conditions sometimes make it easier for the uninformed consumers to recognize differences for their dollars. However, growers are sometimes forced either to sell perfectly acceptable plants at discounts because their dimensions fail to measure up to a particular buyer's prerequisites or to culturally curtail plant growth to keep plants within the standards. Growers also are forced to choose among production strategies depending on the desired market outlet. On the one hand, growers producing for mass marketers typically will grow large quantities of a limited number of products in highly automated operations. On the other hand, growers producing for independents typically will grow fewer numbers of a wider selection of products in much less-automated surroundings.

Consolidation of retailers has also presented some not-so-obvious marketing challenges for growers. There are instances in the marketplace where buyers are placing real or suggested limits on producers about which competitors they can sell to or on how much of a producer's output they are willing to buy. The restraint of trade issues notwithstanding, such actions limit producer options. Growers rightfully want to spread their eggs among as many baskets as possible, but options are dwindling as certain chains continue to consolidate and as financial realities force smaller chains and/or independents out of business.

In many markets, the big box chains often come onto the scene opening huge numbers of stores in a relatively short time. While this is the nature of mass markets, these actions, which have forced smaller retailers from the scene, have also had the effect of forcing producers to scramble to maintain any market opportunities to which they can sell. Sometimes the chains enter a new market and bring established supply relationships with them from distant locations, rather than developing new relationships with local producers. With alternative local retailers pressured, local growers often find themselves challenged to find an inviting market channel.

Conversely, as chains move from market to market, a number of buyers have asked growers to supply not only those stores that have been supplied in the past, but also additional stores being built or acquired. Due to 
production or servicing constraints, additional volume is often beyond the means of certain suppliers. For the sake of buying efficiency, chain buyers have sometimes changed suppliers to those willing to add production volumes. There have also been instances where a chain has changed the buyers or their responsibilities, forcing producers to again compete and establish relationships with the new buyers.

One phenomenon affecting growers is the relatively new auction buying by a number of chains, particularly supermarkets. Perhaps caused by consolidation and/or centralization of buying functions, a number of chains have asked growers to participate in online reverse auctions to bid for their business (e.g., www.florabid.com). In such instances, purchases are made from growers willing to supply to a set of predetermined and written specifications, which are published online. Thus, superior quality is not encouraged nor rewarded, as the product is seldom seen by buyers. Instead, growers are forced to produce to the minimum standards to remain as competitive as possible.

Another decision being considered by several chains is whether to move to a pay-by-scan transaction basis. Today, most chains pay for the product delivered. But several chains (e.g. Home Depot) are considering moving to paying only for the product scanned at checkout. This would force producers to absorb the entire shrinkage now assumed by retailers. It might also force growers to modify their product and/or service protocols to help assure getting paid for their efforts. More frequent deliveries of smaller quantities per delivery and the servicing of retail displays are two possible examples of changes growers will be forced to make. Cash flow considerations are another concern, as well as who pays the costs of employee and/or customer theft. This pay-by-scan change would benefit the retailer, who will be able to radically reduce inventory dollars from their books. Such a move would increase the retailer's return on assets, something of particular importance to Wall Street, as market opportunities become more limited due to store saturation.

\section{STRUCTURAL IMPACTS ON THE INDUSTRY}

The impacts of the mass marketers on the nursery and floricultural industry are tremendous. To their credit, many would argue that the chains have exposed many more consumers to nursery and floral products. There is no doubt that this is true, as the presence of mass marketers has opened not only the consumers' eyes to the industry's products, but additional market opportunities for producers as well. This has forced independent retailers to become more savvy a marketing by looking for ways to increase customer service. Mass marketers have also facilitated the growth of offshore cut flower producers as major suppliers to the U.S. consumer. In recent years, offshore producers have also become providers of many of the cut flower bouquets now offered at retail stores. These bouquets were formerly assembled in the United States near the cities in which they were sold.

Domestically, the impact of the mass marketing of nursery and floricultural crops has led to the increased formation of larger and larger producer operations. The capital requirements needed to afford the infrastructure required to move mass quantities of product in a confined marketing window exceed those that this industry has historically managed. Most firms have been able to generate the capital on their own, but the industry also has seen examples of investment brokers entering the industry to help finance some of these production operations.

In many instances, chain buyers have limited the number of firms with whom they deal in any market area, as chains have come to realize certain efficiencies in merchandising products if fewer vendors are utilized. Chains have begun asking vendors to provide care for in-store displays, especially during the bedding/garden plant season, something that is easier to request if one firm handles all of the merchandise. Whether or not producers are rewarded for the additional expense of providing fully managed displays is debatable, but some growers report that the improved product care leads to additional turns (inventory turnover), which provide the needed results.

There are also several instances of producers partnering with smaller firms in order to handle the volumes required to supply burgeoning chains. In one instance, there may be as many as 40 growers involved in crossdocking activities to satisfy one chain's needs in a market area. Depending on the arrangements, this helps to spread the risk among several producers. Still, there are numerous examples of producers who supply 50 percent, 75 percent, or even 100 percent of their output to one chain; when asked about risk, these growers often respond with discussions about production efficiencies and questions about what they could do even if they wanted to change, noting that their competitors would love to steal the account. 
In contrast, the focus on mass marketers by large growers has created opportunities for smaller growers to develop niches serving independent retailers or to go into retailing themselves, selling directly to the consumer. In a recent survey of growers, it was found that the majority of several thousand producers surveyed did some retailing of their own, whether that was 1 percent or 100 percent of their production. Smaller growers appeared to sell higher percentages, on average, of their production at retail. Yet, some larger producers have also used their own retail sales as a tactic for diversification. In many instances, producers in the middle seemed to focus their production on selling to independent retailers, perhaps including a retail operation of their own.

The other impact of mass marketers on the industry has been one of consolidation. In recent years, grower numbers have appeared to decline from year to year, or at best, remain stable. One could debate why the producer numbers are diminishing, but many would argue that the stresses of either supplying mass marketers or competing with them as an independent grower-retailer are taking their toll. The capitalization requirements, the reduced margins, the increased demands, the risk associated with fewer customer numbers, and the resulting consequences should that risk come to be realized have all created market pressures for larger producers. The struggle to remain competitive in a viable niche for smaller producers can be equally trying in markets being inundated by competing chains. There are already certain markets where independents can hardly be found.

\section{Previous Economic Impact Studies}

In spite of the magnitude and recent growth of the Green Industry outlined above, there is surprisingly little information that has been developed at the national level regarding the economic impact of the Green Industry. The USDA does conduct floriculture and nursery crop surveys to collect information at the grower level, but these data are often incomplete for some states and the cash receipts reported for/by growers do not reflect the further economic impacts generated from this production activity. Census data, including the 10-year Census of Horticultural Specialties, is subject to the same limitations and has historically had other mitigating problems such as poor response rate, which reflects poorly on the data's accuracy. For firms downstream in the supply chain, such as landscapers, re-wholesalers, and retailers, there is Standard Industrial Classification (SIC) data maintained by each state's Office of the Comptroller, but misclassification errors and non-compliance on the part of industry participants have made some state's data speculative at best. There is a new sectoring scheme called the North American Industrial Classification System, or NAICS for short, which should provide more robust estimates in the future. However, to date, no one source of data has proven to be adequate in capturing the total economic importance of the Green Industry.

Recognizing the limitations of existing data sources and also the critical need for this type of economic impact data, several state nursery and landscape associations have sponsored and developed their own economic impact studies for their respective green industries. Such associations have found these studies to be useful in communicating the importance of the Green Industry to state legislatures, in gaining assistance and resources, and in combating proposed legislation that would have had negative impacts on urban or community forestry initiatives and the Green Industry. As useful as these state-specific studies have been, there have not been comparable analyses conducted at the national level that would provide similar benefits on that scale.

Additionally, each of the researchers conducting state-level studies used different research methodologies in their respective analyses, which were completed in different time frames. Thus the cross-sectional and time-series comparability of such studies is quite limited. Nonetheless, this chapter attempts to summarize the findings of previous studies so that a common "point of departure" can be used as a benchmark from which to compare the results from this study which is national in scope.

Table 1-2 presents an overview of previous economic impact studies that have been conducted [in the last five years] regarding the Green Industry in selected states. While there have been other studies conducted (mostly by the Agricultural Statistics Service in respective states) that estimate grower-level sales or cash receipts, this summary only presents those that provide subsequent post-farm gate economic impacts. There have been other economic impact studies conducted in some states regarding turfgrass-related economic impacts (Table 1-3), but the focus here is on the economic impacts of the entire Green Industry. In Table 1-2, the studies are listed by state in alphabetical order. Total Green Industry sales are presented, along with the total employment and payroll associated with Green Industry sectors. Some state studies also provided estimates of value added and taxes paid 
by Green Industry participants and those are listed where applicable. To gain a common basis on which to perform a comparison of the results from each state, total population during the year of the study is tabulated, along with each state's Gross State Product (GSP). In concept, an industry's GSP (or its value added) is equal to its gross output (sales or receipts and other operating income, and inventory change) minus its intermediate inputs (use of goods and services purchased from other U.S. industries or imported). Thus, the GSP accounts provide data by industry and state that are consistent with the Nation's gross domestic product (GDP) by industry accounts. However, total GSP for the Nation differs from GDP in the national income and product accounts for three reasons. First, like the national estimates of GDP by industry, GSP is measured as the sum of the distributions by industry of the components of gross domestic income. Second, GSP excludes (and GDP by industry include) compensation of Federal civilian and military personnel stationed abroad and government consumption of fixed capital for military structures located abroad and for military equipment, except domestically located office equipment. Third, GSP and GDP often have different revision schedules.

Table 1-2 also includes an estimate of the calculated share of each state's GSP that the Green Industry represents; an unadjusted Green Industry sales (impact) per capita calculation; and an adjusted sales (impact) per capita estimate. This adjusted sales impact involves multiplying each unadjusted per capita estimate by the respective GDP implicit price inflator for each respective year to convert all per capita estimates to 2004 dollars. As shown in the table, economic impacts estimated in the selected studies ranged from \$186 million in Massachusetts and Vermont to a high of $\$ 10.3$ billion in California. Florida was a close second with $\$ 9.2$ billion and Texas ranked third with just over $\$ 9$ billion in economic impact. Even with this being a subset of 23 states (only impact studies that have been conducted over the last five years were included), total economic impacts amounted to almost $\$ 60$ billion (not adjusted for inflation). Adjusted per capita economic impacts ranged from $\$ 223$ per person in Maine, largely due to its small industry relative to its population, to a high of $\$ 618$ per person in Florida. The value on a per capita basis averaged across all states was $\$ 380$ per person. The number of jobs represented by Green Industry firms ranged from 5,400 jobs in Vermont to just over 168,900 jobs in California. Texas and Florida ranked second and third in terms of Green Industry-related employment with 222,000 and 187,859 jobs respectively.

However, the reader is cautioned against making direct comparisons from state to state due to the differences in research methods utilized in each state. For example, the data collection procedures often differed dramatically in that some states used mail or telephone surveys to collect primary data, while others relied heavily on secondary data sources, and others used enumerators (often Agricultural Statistics Service personnel) to interview Green Industry participants directly to collect primary data. Another important difference is the number and type of sectors that were included in each respective study's definition of the Green Industry (refer to the last column of Table 1-2). For example, some states included all end users such as households, golf courses, and sports complexes, while others did not. Last, the model used to determine economic multipliers differed between the studies. Many of the researchers used the IMPLAN $®$ (input-output) economic impact modeling system to conduct their respective analysis, but not all.

All of these factors again point to the dire need to conduct a study that is national in scope that uses a common methodology to collect industry data and calculate associated economic impacts. The next chapter will provide a detailed description of the methodology used in this study that was used to guarantee results that will be comparable across states. 
Table 1-3. State-Specific Studies of Economic Impacts of the Green Industry, 1978-2004

Year Reported

2004

2004

2003

2003

2003

2002

2002

2002

2002

2002

2001

2001

2001

2001

2001

2001

2000

2000

2000

2000

2000

2000

2000

1999

1999

1999

1999

1998

1998

1997

1997

1997

1996

1996

1996

1996

1995

1995

1994

1994

1994

1994

1994

1994

1993

1993

1993

1990

1989

1989

1989

1989

1987

1986

1985

1984

1982

1978
State

Wisconsin Green Industry Survey

New England Environmental Horticulture

California

New Jersey

New York

Nevada

Colorado

Michigan

Arizona

Georgia

Iowa

Idaho

Ohio

Louisiana

Illinois

Florida

Kansas

Texas

Virginia

Maryland

Missouri

Pennsylvania

Minnesota

South Carolina

North Carolina

Arizona

Wisconsin

Missouri

New England

Florida

Oregon

Louisiana

Maryland

Mississippi

Washington

Ohio

New Mexico

Louisiana

Arizona

Kansas

North Carolina

South Carolina

South Carolina

Kansas

Colorado

Texas

Tennessee

Michigan

Ohio

Kentucky

Pennsylvania

Michigan

Oklahoma

North Carolina

New Jersey

Rhode Island

Virginia

Oklahoma
Scope

Nursery Industry

Turfgrass Industry

Turfgrass Industry

Green Industry Operations

Green Industry

Turfgrass Industry

Green Industry

Golf Course and Landscape Maintenance

Turfgrass Industry

Green Industry

Green Industry

Green Industry

Green Industry

Environmental Horticulture Industry

Horticulture Industry

Green Industry

Turfgrass Industry

Horticulture Industry

Nursery Industry

Green Industry

Nursery and Landscape Industry

Horticulture Industry

Turfgrass

Green Industry

Turfgrass Industry

Turfgrass Industry

Environmental Horticulture Industry

Environmental Horticultural Industry

Nursery and Greenhouse Industry

Nursery and Turfgrass Industry

Turfgrass Industry

Turfgrass Industry

Nursery and Landscape Industry

Nursery Industry

Turfgrass Industry

Green Industry

Green Industry

Turfgrass Industry

Turfgrass Industry

Golf Industry

Ornamental Horticulture and Turfgrass Industry

Horticulture Industry

Green Industry

Green Industry

Nursery and Floriculture Industry

Nursery and Landscape Industry

Turfgrass Industry

Turfgrass Industry

Turfgrass Industry

Turfgrass Industry

Turfgrass Industry

Turfgrass Industry

Turfgrass Industry

Turfgrass Industry

Turfgrass Industry

Turfgrass Industry 


\section{Research Methodology}

\section{Industry Sector Classification}

The economic sectors associated with the environmental horticulture or "Green" Industry were identified, based on their primary product or service activity as described in the North American Industry Classification System (Office of the President, 1997) as indicated in Table 2-1. Production and manufacturing includes the sectors for nursery and greenhouse, lawn and garden equipment manufacturers, and greenhouse manufacturers (prefabricated metal buildings). The horticultural services sector includes landscaping and landscape architecture. Wholesale and retail trade of horticultural goods includes sectors for flower, nursery stock and florist supplies wholesalers, lawn and garden stores, and florists. In addition, building material and supplies dealers, food and beverage stores, general merchandise stores, and farm and garden equipment wholesalers all have significant sales of horticultural merchandise as port of their overall business.

\section{Table 2-1. Classification of Economic Sectors Associated with the Green Industry}

\begin{tabular}{ll}
\multicolumn{1}{c}{ Industry Sector } & \multicolumn{1}{c}{ NAICS } \\
Code
\end{tabular}

* Merchandise or product line sales of horticultural goods represents a portion of overall business. Source: Executive Office of the President, Office of Management and Budget. North American Industry Classification System, United States, 1997.

\section{Information Sources}

Economic information on the Green Industry in the United States was compiled from a variety of sources. For the nursery and greenhouse sector, national and state information on number of farms and value of sales were taken from the Census of Agriculture for 2002 (USDA, 2004). For the various services and trade sectors, information on number of establishments, employment, and sales (receipts) were taken from the 2002 Economic Census Industry Report Series for U.S. totals, while state-level information on number of firms, employment and payroll in 2002 were taken from County Business Patterns (US Census Bureau, 2004, 2005). For the sectors whose primary business is not in horticulture (such as general merchandise stores), employment and payroll were estimated in proportion to horticulture merchandise or product line sales as a share of total sales. Also, state-level information on number of firms, employment and payroll were adjusted to match the U.S. totals. The Census of Agriculture and Economic Census were considered to be the most reliable information sources available, since they have well-established statistical methodologies, with adjustment for small or non-responding firms, and provide published confidence parameters. For some states in which employment and wages were non-disclosed because of a small number of firms reporting, employment was estimated at the midpoint of the range indicated, and payroll was estimated at the national average annual wages per employee. 
According to Census Bureau data, the number of establishments, employment, payroll, and sales receipts for sectors of the Green Industry in the United States in 2002 are shown in Table 2-2. There were a total of 255,389 business establishments involved in the industry, including 56,233 nursery producers or manufacturers, 82,683 horticultural services firms, and 116,473 wholesale/retail trade firms. Total reported employment was 1.085 million employees, and total payroll was $\$ 46$ billion $(\mathrm{Bn})$, excluding the nursery and greenhouse sector. Total sales receipts in 2002 were $\$ 147.1 \mathrm{Bn}$, including $\$ 23 \mathrm{Bn}$ for producers, $\$ 38.8 \mathrm{Bn}$ for horticultural services, and $\$ 85.3 \mathrm{Bn}$ for wholesale/retail trade.

Table 2-2. Sales and Employment in the U.S. Green Industry, 2002

\begin{tabular}{lrrrr}
\multicolumn{1}{c}{ Sector (NAICS code) } & $\begin{array}{c}\text { Establish- } \\
\text { ments }\end{array}$ & $\begin{array}{r}\text { Paid } \\
\text { Employees }\end{array}$ & $\begin{array}{r}\text { Annual } \\
\text { Payroll } \\
(\mathbf{M n})\end{array}$ & $\begin{array}{c}\text { Sales } \\
\text { Receipts } \\
(\mathbf{\$ M n})\end{array}$ \\
\hline Production/Manufacturing & $\mathbf{5 6 , 2 3 3}$ & $\mathbf{1 7 3 , 4 0 3}$ & $\mathbf{2 6 , 8 9 6}$ & $\mathbf{2 3 , 0 0 0}$ \\
Nursery \& Greenhouse (1114) & 56,070 & 150,543 & 4,459 & 16,362 \\
Lawn \& Garden Equipment Manufacturing (33311) & 145 & 22,201 & 681 & 6,517 \\
Prefabricated metal buildings (332311) (Greenhouses)* & 18 & 659 & 21,756 & 121 \\
Horticultural Services & $\mathbf{8 2 , 6 8 3}$ & $\mathbf{5 5 1 , 6 4 1}$ & $\mathbf{1 2 , 8 3 9}$ & $\mathbf{3 8 , 8 0 4}$ \\
Landscaping Services (56173) & 76,458 & 514,962 & 11,509 & 35,235 \\
Landscape Architectural Services (54132) & 6,225 & 36,679 & 1,330 & 3,569 \\
Wholesale \& Retail Trade Horticulture Products & $\mathbf{1 1 6 , 4 7 3}$ & $\mathbf{5 1 0 , 5 1 2}$ & $\mathbf{1 0 , 6 7 6}$ & $\mathbf{8 5 , 3 0 5}$ \\
Flower, Nursery Stock and Florist Supplies Wholesalers (42493) & 4,816 & 60,010 & 1,580 & 10,022 \\
Lawn \& Garden Equipment \& Supplies Stores (4442) & 21,065 & 171,149 & 3,769 & 30,953 \\
Florists (4531) & 22,753 & 113,929 & 1,489 & 6,597 \\
Building Material \& Supplies Dealers (4441)* & 18,623 & 60,450 & 1,608 & 13,201 \\
Food \& Beverage Stores (445)* & 22,465 & 19,222 & 330 & 3,090 \\
General Merchandise Stores (452)* & 22,710 & 56,651 & 955 & 9,898 \\
Farm \& Garden Equipment Wholesalers (42382)* & 4,041 & 29,102 & 945 & 11,541 \\
Total All Sectors & $\mathbf{2 5 5 , 3 8 9}$ & $\mathbf{1 , 2 3 5 , 5 5 7}$ & $\mathbf{5 0 , 4 1 0}$ & $\mathbf{1 4 7 , 1 0 9}$ \\
\hline
\end{tabular}

* Payroll and employment estimated proportional to merchandise line sales of total sales.

Sources: 2002 Economic Census, 2002 Census of Agriculture (USDA/NASS), 2001 Implan data for the US (nursery \& greenhouse employment, payroll)

Primary market research data regarding the structure and performance of the nursery industry were generated by the Fourth National Nursery Industry survey conducted by the S290 Multi-state Regional Research Committee, a group of agricultural economists and horticulturists from 24 land-grant institutions across the country (including the principal investigators of this project). A total of 44 states participated in this survey. It is through the S290 survey efforts conducted in early 2004 that detailed data regarding sales of urban forest tree species were collected. For the first time in the survey's history, a standard methodology of obtaining a sample frame was used. The population lists for each state were assembled from the respective Department of Agriculture offices responsible for licensing nursery producers. A master file of all certified/licensed nursery operations was compiled at the University of Florida. Two states that had recently completed nursery surveys were excluded (AL and AZ) in addition to four other states that had extremely small nursery numbers (AK, KS, MD, and WI). The remaining 44 states resulted in a combined listing of 38,269 certified/licensed nursery operations. Based on considerations of budget and statistical reliability, a sample of 15,888 firms was selected for the survey, with sampling in each state based on its proportion of the overall nursery population. Where information was available on nursery production area, inventory or sales volume, sampling was stratified for three size classes: small (less than five acres), medium (5 to 19 acres), and large (20 or more acres). Sampling was weighted on larger firms, with 100 percent of the large nurseries, 60 percent of the medium nurseries, and 25 percent of the small nurseries. In several states, the nursery acreage values were not available, or not available for all certified or licensed operations, and in these states 40 percent of the identified firms were sampled. The final sample included 3,476 large nurseries, 3,778 in the medium category, 5,996 of the small firms, and 2,338 of unknown size. There were a total of 2,485 usable returned questionnaires returned, representing an overall response rate 15.9 percent. The number of respondents from individual states ranged from as few as 10 in Nevada to 476 in Florida. 


\section{Economic Impact Analysis}

To evaluate the broad regional economic impacts of the Green Industry in the United States, regional economic models were developed for each state using the Implan software system and associated state datasets (MIG, Inc., 2004). The Implan system includes over 500 distinct industry sectors. The sectors pertinent to the Green Industry are indicated in Table 2-3 and Figure 2-1. The information for these models was derived from the U.S. National Income and Product Accounts, together with regional economic data collected by the U.S. Department of Commerce, Bureau of Economic Analysis. Input-output models represent the structure of a regional economy in terms of transactions between industries, employees, households, and government institutions (Miller \& Blair, 1985). The Implan data used for this analysis was based on fiscal year 2001.

Economic multipliers derived from the models were used to estimate the total economic activity generated in each state by sales (or output) to final demand or exports. This includes the effects of intermediate purchases by industry firms from other economic sectors (indirect effects) and the effects of industry employee household consumer spending (induced effects), in addition to direct sales by industry firms. The regional Implan models were constructed as fully closed models, with all household, government, and capital accounts treated as endogenous, to derive Social Accounting Matrix (SAM) type multipliers, which represent transfer payments as well as earned income. Separate multipliers are provided for output (sales), employment, value added, labor income, and business taxes. The output total effects multipliers for each industry sector and state are shown in Table 2-4. The direct, indirect, and induced effects multipliers for output, value added and employment for each industry sector are shown in the Appendix Tables. The multipliers for output, value added, labor income, and indirect business taxes are expressed in units of dollars per dollar output, while the employment multiplier is expressed in jobs per million dollars output. The total output multipliers generally range from 1.8 to 2.8 , meaning that for each dollar of sales to final demand, total output generated in the region (state) is $\$ 1.80$ to $\$ 2.80$. Differences in values of the multipliers reflect the structure of industry sectors and regional mix of supplier industries. The multipliers were applied to estimated industry sales or output in order to estimate total economic impacts. For the producer and service sectors, total economic impacts were estimated as:

$$
\mathrm{I}_{\mathrm{hij}}=\mathrm{S}_{\mathrm{hi}} \mathrm{x}\left[\mathrm{A}_{\mathrm{hij}}+\mathrm{E}_{\mathrm{hi}} \mathrm{x}\left(\mathrm{B}_{\mathrm{hij}}+\mathrm{C}_{\mathrm{hij}}\right)\right] \text {; }
$$

and for the wholesale trade sectors, impacts were estimated as:

$$
I_{h i j}=S_{h i} \times G_{i}\left[A_{h i j}+E_{h i} \times\left(B_{h i j}+C_{h i j}\right)\right]
$$

and for the retail trade sectors, impacts were estimated as:

$$
I_{h i j}=S_{h i} \times G_{i}\left[A_{h i j}+B_{h i j}+C_{h i j}\right]
$$

where

$\mathrm{I}_{\mathrm{hij}}$ is total impact for measures (j) of output, employment, value added, labor income, or indirect business. taxes, in each sector (i), and state (h).

$\mathrm{S}_{\mathrm{hi}}$ is industry sales in sector $\mathrm{i}$ and state $\mathrm{h}$.

$E_{h i}$ is the proportion of industry sales exported or shipped outside the state, by sector $i$ in state $h$.

$\mathrm{A}_{\mathrm{hij}}$ is the direct effects multiplier for measure $\mathrm{j}$ in sector $\mathrm{i}$ and state $\mathrm{h}$.

$B_{\text {hij }}$ is the indirect effects multiplier for measure $j$ in sector $i$ and state $h$.

$\mathrm{C}_{\mathrm{hij}}$ is the induced effects multiplier for measure $\mathrm{j}$ in sector $\mathrm{i}$ and state $\mathrm{h}$.

$\mathrm{G}_{\mathrm{i}}$ is the gross margin on retail sales for sector $\mathrm{i}$.

The calculation for the producer, wholesale, and service sectors assumes that only the export portion of output is sold to final demand, and therefore is subject to the indirect and induced effects multipliers, while the remainder of in-state sales is subject to intermediate demand from other business sectors and to direct effects multipliers. Data on exports were taken from the Implan database for 2001 or 1999, except in the case of the nursery and greenhouse sector, where information for some states was taken from the 2003 National Nursery Survey. The calculation for retail and wholesale sectors assumed output is reduced to reflect only the gross margin on sales according to national averages: 20.1 percent for flower and nursery stock wholesalers, 24.7 percent for general merchandise stores, 26.5 percent for lawn and garden equipment wholesalers, 28.5 percent for food and beverage stores, 29.5 percent for lawn and garden stores, 29.5 percent for building materials and supply stores, 42.3 percent for florists (miscellaneous retailers) [Census Bureau, Annual Benchmark Reports for Retail Trade \& Food 
Services, and for Wholesale Trade]. All results were stated in 2004 dollars by adusting values using the Gross Domestic Product (GDP) Implicit Price Deflator (U.S. Department of Commerce).

Table 2-3. Implan Sectors Used for Economic Impact Analysis of the Green Industry Implan Sector Name (Number)

Nursery \& Greenhouse (6)

Lawn \& Garden Equipment Mfg (258)

Prefabricated Metal Building \& Component Mfg. (232)

Services To Buildings And Dwellings (458)

Architectural And Engineering Services (439)

Wholesale Trade (390)

Building Material And Garden Supply Stores (404)

Miscellaneous Store Retailers (411)

Food And Beverage Stores (405)

General Merchandise Stores (410)
Horticulture Industry Sector Covered

Nursery \& Greenhouse

Lawn \& Garden Equipment Mfg

Greenhouse Manufacturing

Landscaping Services

Landscape Architectural Services

Flower, Nursery Stock \& Florist Supplies Wholesalers Farm \& Garden Machinery \& Equipment Wholesalers Lawn \& Garden Equipment \& Supplies Stores Building Material \& Supplies Dealers

Florists

Food \& Beverage Stores

General Merchandise Stores

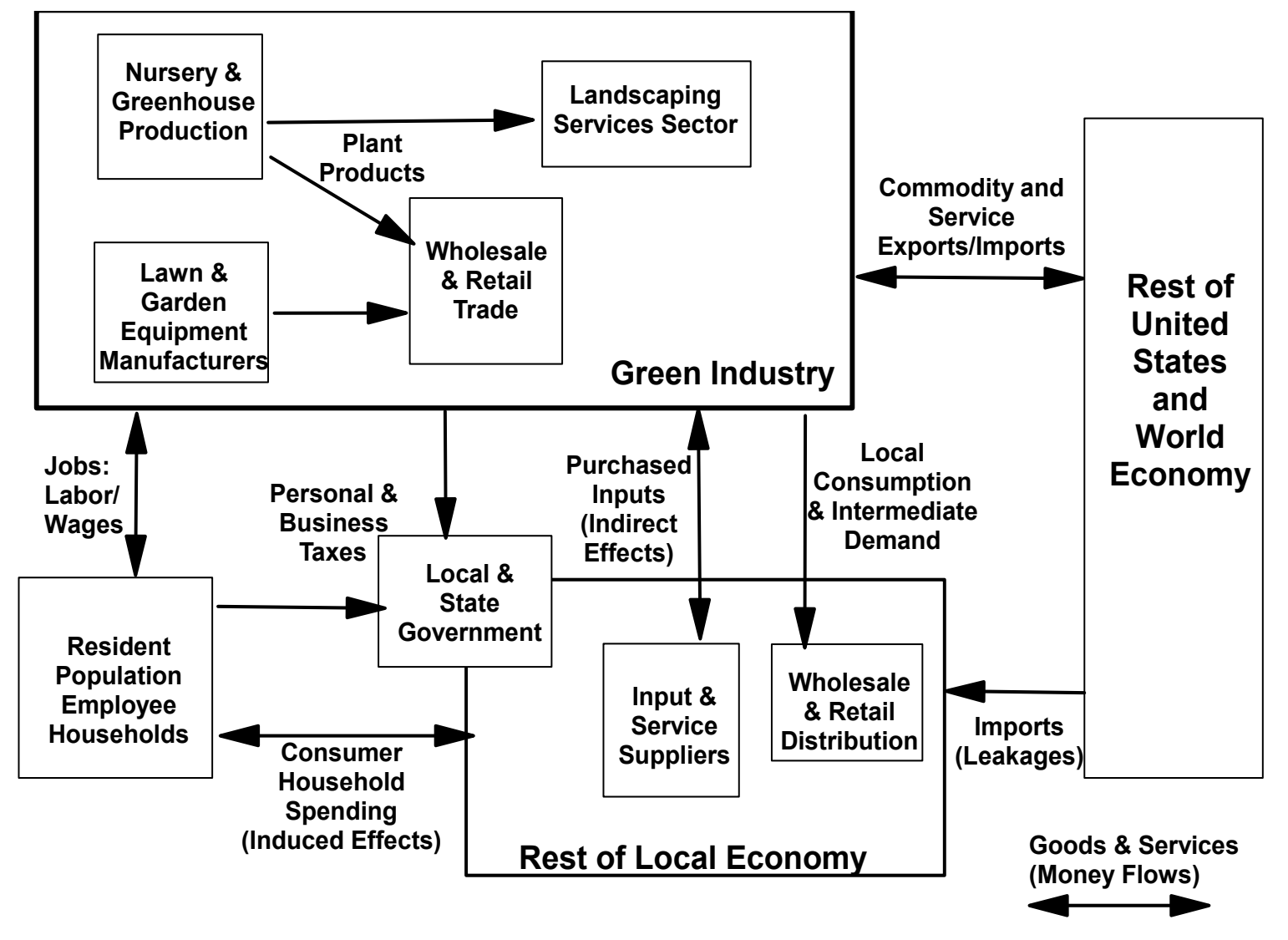

Figure 2-1. Market Structure and Economic Linkages of the Green Industry 
Table 2-4. Output Total Effects Multipliers for the Green Industry, by Sector and State (2001)

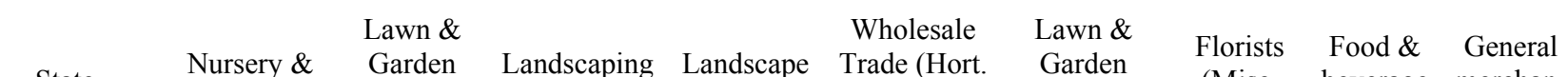

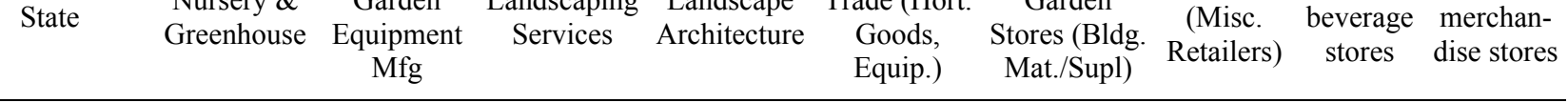

\begin{tabular}{|c|c|c|c|c|c|c|c|c|c|}
\hline Alabama & 1.976 & 1.932 & 2.186 & 2.104 & 2.166 & 2.157 & 2.143 & 2.156 & 2.156 \\
\hline Alaska & 1.877 & 0.000 & 1.991 & 2.017 & 1.997 & 2.024 & 2.030 & 2.026 & 2.019 \\
\hline Arizona & 2.213 & 1.929 & 2.368 & 2.390 & 2.438 & 2.436 & 2.483 & 2.456 & 2.433 \\
\hline Arkansas & 1.922 & 1.768 & 2.051 & 1.997 & 2.051 & 2.063 & 2.065 & 2.069 & 2.062 \\
\hline California & 2.480 & 2.180 & 2.687 & 2.666 & 2.722 & 2.711 & 2.790 & 2.743 & 2.712 \\
\hline Colorado & 2.434 & 2.222 & 2.613 & 2.635 & 2.714 & 2.703 & 2.768 & 2.725 & 2.700 \\
\hline Connecticut & 2.011 & 0.000 & 2.289 & 2.258 & 2.318 & 2.318 & 2.414 & 2.361 & 2.321 \\
\hline Delaware & 1.873 & 0.000 & 2.020 & 1.976 & 2.025 & 2.040 & 2.033 & 2.041 & 2.037 \\
\hline Florida & 2.370 & 2.001 & 2.572 & 2.548 & 2.603 & 2.600 & 2.661 & 2.636 & 2.597 \\
\hline Georgia & 2.258 & 2.157 & 2.547 & 2.530 & 2.580 & 2.580 & 2.646 & 2.618 & 2.582 \\
\hline Hawaii & 2.303 & 0.000 & 2.419 & 2.388 & 2.392 & 2.412 & 2.401 & 2.411 & 2.410 \\
\hline Idaho & 2.052 & 0.000 & 2.190 & 2.147 & 2.164 & 2.175 & 2.200 & 2.191 & 2.176 \\
\hline Illinois & 2.387 & 2.435 & 2.627 & 2.643 & 2.690 & 2.693 & 2.782 & 2.736 & 2.696 \\
\hline Indiana & 2.092 & 2.096 & 2.232 & 2.187 & 2.261 & 2.275 & 2.298 & 2.291 & 2.274 \\
\hline Iowa & 1.955 & 1.903 & 2.116 & 2.066 & 2.133 & 2.122 & 2.113 & 2.122 & 2.119 \\
\hline Kansas & 2.119 & 1.876 & 2.268 & 2.218 & 2.286 & 2.292 & 2.309 & 2.305 & 2.291 \\
\hline Kentucky & 1.916 & 1.874 & 2.071 & 2.021 & 2.018 & 2.037 & 2.048 & 2.046 & 2.039 \\
\hline Louisiana & 2.061 & 1.736 & 2.193 & 2.184 & 2.226 & 2.220 & 2.228 & 2.228 & 2.215 \\
\hline Maine & 2.010 & 1.672 & 2.128 & 2.098 & 2.136 & 2.122 & 2.067 & 2.105 & 2.117 \\
\hline Maryland & 2.393 & 2.128 & 2.603 & 2.629 & 2.622 & 2.623 & 2.634 & 2.633 & 2.622 \\
\hline Massachusetts & 2.205 & 2.023 & 2.423 & 2.430 & 2.453 & 2.453 & 2.527 & 2.495 & 2.456 \\
\hline Michigan & 2.140 & 2.060 & 2.305 & 2.269 & 2.322 & 2.343 & 2.405 & 2.376 & 2.345 \\
\hline Minnesota & 2.317 & 2.091 & 2.552 & 2.545 & 2.605 & 2.607 & 2.688 & 2.645 & 2.607 \\
\hline Mississippi & 1.908 & 1.822 & 2.063 & 1.985 & 2.049 & 2.043 & 2.018 & 2.036 & 2.039 \\
\hline Missouri & 2.255 & 2.182 & 2.455 & 2.411 & 2.495 & 2.505 & 2.588 & 2.544 & 2.507 \\
\hline Montana & 1.888 & 0.000 & 2.021 & 2.041 & 2.013 & 2.016 & 1.952 & 1.997 & 2.014 \\
\hline Nebraska & 1.978 & 1.905 & 2.249 & 2.242 & 2.315 & 2.299 & 2.303 & 2.306 & 2.295 \\
\hline Nevada & 2.156 & 0.000 & 2.193 & 2.201 & 2.192 & 2.215 & 2.237 & 2.225 & 2.216 \\
\hline New Hampshire & 2.150 & 0.000 & 2.303 & 2.247 & 2.301 & 2.305 & 2.327 & 2.319 & 2.303 \\
\hline New Jersey & 1.996 & 1.894 & 2.299 & 2.262 & 2.321 & 2.318 & 2.419 & 2.368 & 2.320 \\
\hline New Mexico & 2.078 & 0.000 & 2.198 & 2.194 & 2.255 & 2.241 & 2.247 & 2.246 & 2.235 \\
\hline New York & 1.979 & 2.053 & 2.207 & 2.238 & 2.276 & 2.276 & 2.378 & 2.334 & 2.278 \\
\hline North Carolina & 2.095 & 2.034 & 2.348 & 2.268 & 2.325 & 2.318 & 2.319 & 2.320 & 2.317 \\
\hline North Dakota & 1.768 & 1.587 & 1.960 & 1.934 & 1.957 & 1.959 & 1.942 & 1.952 & 1.957 \\
\hline Ohio & 2.016 & 1.862 & 2.205 & 2.185 & 2.156 & 2.217 & 2.287 & 2.254 & 2.220 \\
\hline Oklahoma & 2.276 & 1.985 & 2.387 & 2.304 & 2.357 & 2.361 & 2.362 & 2.369 & 2.362 \\
\hline Oregon & 2.307 & 1.934 & 2.386 & 2.318 & 2.321 & 2.340 & 2.438 & 2.382 & 2.341 \\
\hline Pennsylvania & 2.292 & 2.166 & 2.481 & 2.479 & 2.493 & 2.509 & 2.601 & 2.550 & 2.512 \\
\hline Rhode Island & 1.884 & 0.000 & 2.024 & 1.991 & 1.998 & 2.007 & 1.964 & 1.992 & 2.005 \\
\hline South Carolina & 1.986 & 1.871 & 2.164 & 2.088 & 2.134 & 2.134 & 2.109 & 2.126 & 2.130 \\
\hline South Dakota & 1.870 & 1.798 & 2.090 & 2.065 & 2.128 & 2.110 & 2.053 & 2.082 & 2.105 \\
\hline Tennessee & 2.289 & 2.089 & 2.409 & 2.337 & 2.387 & 2.384 & 2.414 & 2.403 & 2.384 \\
\hline Texas & 2.490 & 2.142 & 2.593 & 2.534 & 2.588 & 2.551 & 2.600 & 2.576 & 2.548 \\
\hline Utah & 2.424 & 2.201 & 2.595 & 2.560 & 2.618 & 2.621 & 2.654 & 2.640 & 2.621 \\
\hline Vermont & 1.985 & 1.745 & 2.133 & 2.109 & 2.159 & 2.159 & 2.165 & 2.167 & 2.158 \\
\hline Virginia & 2.213 & 1.929 & 2.423 & 2.405 & 2.463 & 2.481 & 2.523 & 2.503 & 2.480 \\
\hline Washington & 2.161 & 1.796 & 2.306 & 2.251 & 2.231 & 2.254 & 2.309 & 2.279 & 2.259 \\
\hline West Virginia & 1.921 & 0.000 & 1.939 & 1.878 & 1.853 & 1.870 & 1.853 & 1.869 & 1.872 \\
\hline Wisconsin & 2.090 & 2.083 & 2.251 & 2.223 & 2.274 & 2.278 & 2.312 & 2.298 & 2.278 \\
\hline Wyoming & 1.881 & 0.000 & 1.935 & 1.931 & 1.942 & 1.940 & 1.934 & 1.939 & 1.936 \\
\hline
\end{tabular}

Source: Implan 50 state data package, 2001 (MIG, Inc. 2004) 


\section{Results for All Sectors}

\section{National Results}

Economic impact estimates for each group and sector of the U.S. Green Industry are summarized in Table 3-1. Estimated impacts for all states were $\$ 147.8$ billion (Bn) in output, 1,964,339 jobs, $\$ 95.1 \mathrm{Bn}$ in value added, $\$ 64.3 \mathrm{Bn}$ in labor income, and \$6.9 Bn in indirect business taxes. Note that values for 2002 are stated in 2004 dollars. For the production and manufacturing sectors, including nurseries/greenhouses, lawn and garden equipment manufacturers, and greenhouse manufacturers, total output impacts were $\$ 34.6 \mathrm{Bn}$, employment impacts were 300,677 jobs, and value added impacts were \$20.8 Bn. For the horticultural services sectors, including landscape services and landscape architects, total output impacts were $\$ 57.8 \mathrm{Bn}$, employment impacts were 753,557 jobs, and value added impacts were $\$ 39.0 \mathrm{Bn}$. For the wholesale/retail trade sectors, total output impacts were $\$ 55.5 \mathrm{Bn}$, employment impacts were 910,104 jobs, and value added impacts were \$35.3 Bn.

The largest individual sectors in terms of output impact were landscaping services ( $\$ 53.0 \mathrm{Bn})$, nurseries and greenhouses $(\$ 26.1 \mathrm{Bn})$, retail lawn and garden stores $(\$ 22.9 \mathrm{Bn})$, building material supply stores $(\$ 10.0 \mathrm{Bn})$, lawn and garden equipment manufacturers $(\$ 8.3 \mathrm{Bn})$, and florists $(\$ 7.2 \mathrm{Bn})$. In terms of employment impacts, the largest individual sectors were landscaping services (704,875 jobs), lawn and garden stores (347,916 jobs), nurseries and greenhouses (261,408 jobs), florists (200,451 jobs), and building material supply stores (123,591 jobs). Value added impacts by sectors were as follows: landscaping services ( $\$ 35.6 \mathrm{Bn})$; nurseries and greenhouses $(\$ 18.1 \mathrm{Bn})$; lawn \& garden stores $(\$ 14.8 \mathrm{Bn})$; building material \& supply stores $(\$ 6.5 \mathrm{Bn})$; general merchandise stores $(\$ 4.0 \mathrm{Bn})$; florists $(\$ 4.0 \mathrm{Bn})$; landscape architects $(\$ 3.4 \mathrm{Bn})$; lawn and garden equipment manufacturers ( $\$ 2.6 \mathrm{Bn})$; lawn and garden equipment wholesalers $(\$ 2.7 \mathrm{Bn})$; wholesale flower, nursery stock, and florist supplies ( $\$ 1.9 \mathrm{Bn})$; and food \& beverage stores $(\$ 1.4 \mathrm{Bn})$.

Table 3-1. Economic Impacts of the U.S. Green Industry, by Sector, 2002

\begin{tabular}{|c|c|c|c|c|c|}
\hline Industry Group/Sector (NAICS) & $\begin{array}{l}\text { Output } \\
\text { (\$Mn)* }\end{array}$ & $\begin{array}{c}\text { Employ- } \\
\text { ment } \\
\text { (jobs) }\end{array}$ & $\begin{array}{l}\text { Value } \\
\text { Added } \\
(\$ M n)^{*}\end{array}$ & $\begin{array}{l}\text { Labor } \\
\text { Income } \\
(\$ M n)^{*}\end{array}$ & $\begin{array}{c}\text { Indirect } \\
\text { Business } \\
\text { Taxes } \\
(\$ M n)^{*}\end{array}$ \\
\hline Production \& Manufacturing & 34,578 & 300,677 & 20,796 & 11,037 & 784 \\
\hline Nursery \& Greenhouse (1114) & 26,053 & 261,408 & 18,076 & 9,612 & 647 \\
\hline Lawn \& Garden Equipment Mfg (333112) & 8,281 & 37,343 & 2,610 & 1,346 & 129 \\
\hline Greenhouse Mfg (332311) & 244 & 1,927 & 110 & 78 & 7 \\
\hline Horticultural Services & $\mathbf{5 7 , 7 7 4}$ & $\mathbf{7 5 3 , 5 5 7}$ & 39,013 & 30,269 & 1,387 \\
\hline Landsc & 71 & 704,875 & 35,564 & 27,719 & 1,312 \\
\hline e Architecture (54132) & 4,803 & 48,683 & 3,449 & 2,549 & 74 \\
\hline $\begin{array}{l}\text { Wholesale \& Retail Trade } \\
\quad \text { Wholesale Flowers, Nursery Stock and }\end{array}$ & 55,475 & 910,104 & 35,275 & 23,044 & 4,701 \\
\hline Florist Supplies (42293) & 2,879 & 68,969 & 1,907 & 1,130 & 440 \\
\hline Garden Equipment Wholesale (421820) & 4,146 & 40,617 & 2,737 & 1,601 & 657 \\
\hline Lawn \& Gard & 22,859 & 347,916 & 14,806 & 9,747 & 1,810 \\
\hline Building Material Supply Stores (4441) & 9,982 & 123,591 & 6,491 & 4,258 & 789 \\
\hline Florists (4531) & 7,195 & 200,451 & 3,977 & 2,725 & 401 \\
\hline Food \& beverage stores (445) & 2,263 & 35,117 & 1,385 & 944 & 156 \\
\hline General merchandise stores (452) & 6,150 & 93,443 & 3,973 & 2,639 & 448 \\
\hline Total All Sectors & 147,828 & $1,964,339$ & 95,084 & 64,349 & 6,872 \\
\hline
\end{tabular}

* Values expressed in 2004 dollars (GDP Implicit Price Deflator, US Dept. Commerce) 


\section{State and Regional Results}

Total output, employment, and value added impacts are summarized by state and region for each sector in Table 3-2 and Figures 3-1, 3-2, and 3-3. Output, employment, and value added impacts are detailed by individual sectors and states in Figures 3-4, 3-5, and 3-6 and Tables 3-3, 3-4, and 3-5, respectively. Total value added impacts were largest in the Midwest region ( $\$ 19.2 \mathrm{Bn}$ ), followed by the Pacific region ( $\$ 18.4 \mathrm{Bn})$, Northeast $(\$ 17.9 \mathrm{Bn})$, and Southeast ( $\$ 13.5 \mathrm{Bn})$. The largest individual states in terms of output impacts (Figure 3-7), all exceeding \$4 billion, were California (\$20.4 Bn), Florida (\$9.9 Bn), Texas (\$9.7 Bn), Illinois (\$6.9 Bn), Ohio (\$5.9 Bn), Pennsylvania (\$5.6 Bn), New York (\$5.3 Bn), North Carolina (\$5.2 Bn), Michigan (\$4.8 Bn), and Georgia (\$4.2 Bn). The largest individual states in terms of employment (Figure 3-8), all exceeding 60,000 FTE employees, were California (253,977), Florida (147,795), Texas $(140,295)$, Ohio $(79,841)$, Pennsylvania $(75,829)$, Illinois (75,110), North Carolina $(67,472)$, Georgia $(62,493)$, and New York $(62,113)$. The largest individual states in terms of value added impacts (Figure 3-9), all exceeding $\$ 3$ billion, were California ( $\$ 13.7$ Bn), Florida $(\$ 7.1 \mathrm{Bn})$, Texas $(\$ 6.1 \mathrm{Bn})$, Illinois $(\$ 4.3 \mathrm{Bn})$, Pennsylvania $(\$ 3.7 \mathrm{Bn})$, New York $(\$ 3.5 \mathrm{Bn})$ and Ohio $(\$ 3.5 \mathrm{Bn})$. Detailed results for the major industry group of production/manufacturing, horticultural services and wholesale/retail trade are given in chapters 4,5 , and 6 , respectively.

The Green Industry share of gross state product (GSP) by state is presented in Figure 3-10. GSP is the value added by the labor and property located in a state and is derived as the sum of the GSP originating in all industries in the state. In concept an industry's GSP, referred to as its "value added", is equivalent to its gross output (sales or receipts and other operating income, commodity taxes, and inventory change) minus its intermediate inputs (consumption of goods and services purchased from other U.S. industries or imported). Thus, GSP is often considered the state counterpart of the nation's GDP - one of the most featured measures of U.S. output. In practice, GSP estimates are measured as the sum of the distributions by industry and state of the components of gross domestic income -- that is, the sum of the costs incurred and incomes earned in the production of GDP. In the U.S., the total value added of the Green Industry $(\$ 95.1 \mathrm{Bn})$ represents slightly less than 1 percent of the GSP sum of all states $(\$ 10,830 \mathrm{Bn})$. The top five states with the highest relative percentage of state GSP (Figure 12) included Oregon (1.7\%), Idaho (1.4\%), South Carolina (1.4\%), Florida (1.3\%) and Wisconsin (1.2\%).

\section{Table 3-2. Economic Impacts of the U.S. Green Industry by State/Region and Industry Group,} 2002

\begin{tabular}{|c|c|c|c|c|c|c|c|c|c|c|c|c|}
\hline \multirow[b]{2}{*}{ Region/State } & \multicolumn{4}{|c|}{ Output Impacts (\$Mn)* } & \multicolumn{4}{|c|}{ Employment Impacts (jobs) } & \multicolumn{4}{|c|}{ Value Added Impacts (\$Mn)* } \\
\hline & $\begin{array}{c}\text { All } \\
\text { Sectors }\end{array}$ & $\begin{array}{l}\text { Prod. \& } \\
\text { Manuf. }\end{array}$ & $\begin{array}{l}\text { Hort. } \\
\text { Service }\end{array}$ & Trade & All Sectors & $\begin{array}{l}\text { Prod. \& } \\
\text { Manuf. }\end{array}$ & $\begin{array}{l}\text { Hort. } \\
\text { Service }\end{array}$ & Trade & $\begin{array}{c}\text { All } \\
\text { Sectors }\end{array}$ & $\begin{array}{l}\text { Prod. \& } \\
\text { Manuf }\end{array}$ & $\begin{array}{l}\text { Hort. } \\
\text { Service }\end{array}$ & Trade \\
\hline East & 41,118 & 8,543 & 17,282 & 15,293 & 540,496 & 82,198 & 208,434 & 249,865 & 27,033 & 5,494 & 11,749 & 9,790 \\
\hline Northeast & 26,568 & 4,283 & 11,993 & 10,292 & 336,027 & 43,799 & 131,563 & 160,664 & 17,867 & 2,986 & 8,250 & 6,632 \\
\hline Connecticut & 2,350 & 453 & 1,143 & 754 & 27,026 & 4,807 & 11,213 & 11,006 & 1,659 & 375 & 787 & 496 \\
\hline Delaware & 448 & 53 & 228 & 166 & 6,359 & 375 & 3,194 & 2,789 & 297 & 44 & 148 & 104 \\
\hline Maine & 509 & 56 & 253 & 201 & 7,825 & 665 & 3,252 & 3,908 & 331 & 39 & 166 & 126 \\
\hline Maryland & 3,524 & 605 & 1,807 & 1,112 & 46,725 & 5,666 & 22,596 & 18,463 & 2,440 & 478 & 1,230 & 732 \\
\hline Massachusetts & 3,239 & 199 & 1,787 & 1,252 & 37,553 & 3,411 & 16,549 & 17,593 & 2,159 & 122 & 1,225 & 811 \\
\hline New Hampshire & 729 & 104 & 316 & 309 & 10,153 & 1,470 & 3,584 & 5,099 & 465 & 63 & 208 & 194 \\
\hline New Jersey & 4,210 & 580 & 2,128 & 1,502 & 52,929 & 7,042 & 23,219 & 22,668 & 2,875 & 436 & 1,459 & 980 \\
\hline New York & 5,265 & 751 & 1,887 & 2,627 & 62,113 & 5,344 & 18,704 & 38,065 & 3,511 & 437 & 1,363 & 1,711 \\
\hline Pennsylvania & 5,589 & 1,377 & 2,091 & 2,120 & 75,829 & 13,803 & 25,433 & 36,593 & 3,672 & 924 & 1,430 & 1,319 \\
\hline Rhode Island & 403 & 67 & 233 & 103 & 5,289 & 895 & 2,474 & 1,920 & 262 & 41 & 156 & 65 \\
\hline Vermont & 302 & 37 & 119 & 146 & 4,225 & 322 & 1,344 & 2,559 & 196 & 25 & 78 & 93 \\
\hline Appalachian & 14,550 & 4,260 & 5,289 & 5,001 & 204,469 & 38,398 & 76,871 & 89,200 & 9,166 & 2,508 & 3,500 & 3,159 \\
\hline Kentucky & 1,257 & 138 & 373 & 746 & 21,649 & 1,941 & 5,644 & 14,065 & 821 & 112 & 245 & 464 \\
\hline North Carolina & 5,155 & 1,756 & 1,925 & 1,473 & 67,472 & 12,992 & 29,072 & 25,408 & 3,583 & 1,387 & 1,261 & 935 \\
\hline Tennessee & 3,854 & 1,741 & 975 & 1,138 & 50,812 & 16,603 & 13,793 & 20,416 & 2,050 & 689 & 648 & 713 \\
\hline Virginia & 3,914 & 584 & 1,869 & 1,460 & 56,905 & 5,771 & 26,059 & 25,074 & 2,493 & 308 & 1,249 & 936 \\
\hline West Virginia & 371 & 40 & 147 & 183 & 7,631 & 1,091 & 2,303 & 4,237 & 220 & 13 & 96 & 111 \\
\hline Central & 34,825 & 7,017 & 11,887 & 15,920 & 439,955 & 46,114 & 136,824 & 257,016 & 21,070 & 3,142 & 7,958 & 9,970 \\
\hline
\end{tabular}




\begin{tabular}{|c|c|c|c|c|c|c|c|c|c|c|c|c|}
\hline \multirow[b]{2}{*}{ Region/State } & \multicolumn{4}{|c|}{ Output Impacts (\$Mn)* } & \multicolumn{4}{|c|}{ Employment Impacts (jobs) } & \multicolumn{4}{|c|}{ Value Added Impacts $(\$ M n) *$} \\
\hline & $\begin{array}{c}\text { All } \\
\text { Sectors }\end{array}$ & $\begin{array}{l}\text { Prod. \& } \\
\text { Manuf. }\end{array}$ & $\begin{array}{l}\text { Hort. } \\
\text { Service }\end{array}$ & Trade & All Sectors & $\begin{array}{l}\text { Prod. \& } \\
\text { Manuf. }\end{array}$ & $\begin{array}{l}\text { Hort. } \\
\text { Service }\end{array}$ & Trade & $\begin{array}{c}\text { All } \\
\text { Sectors }\end{array}$ & $\begin{array}{l}\text { Prod. \& } \\
\text { Manuf }\end{array}$ & $\begin{array}{l}\text { Hort. } \\
\text { Service }\end{array}$ & Trade \\
\hline Midwest & 31,825 & 6,663 & 11,179 & 13,984 & 397,099 & 44,061 & 127,054 & 225,984 & 19,243 & 2,994 & 7,494 & 8,754 \\
\hline Illinois & 6,897 & 958 & 2,876 & 3,063 & 75,110 & 4,666 & 26,727 & 43,718 & 4,335 & 430 & 1,972 & 1,933 \\
\hline Indiana & 3,010 & 522 & 1,140 & 1,348 & 41,714 & 3,407 & 14,632 & 23,676 & 1,804 & 229 & 745 & 830 \\
\hline Iowa & 1,459 & 134 & 329 & 996 & 20,820 & 823 & 4,371 & 15,627 & 906 & 62 & 216 & 627 \\
\hline Michigan & 4,845 & 1,122 & 1,796 & 1,927 & 58,745 & 9,269 & 18,110 & 31,365 & 2,991 & 564 & 1,221 & 1,205 \\
\hline Minnesota & 3,099 & 557 & 932 & 1,610 & 37,696 & 3,152 & 10,080 & 24,465 & 1,864 & 237 & 616 & 1,010 \\
\hline Missouri & 2,488 & 363 & 704 & 1,422 & 37,690 & 2,539 & 9,994 & 25,157 & 1,495 & 134 & 470 & 890 \\
\hline Ohio & 5,855 & 1,303 & 2,354 & 2,198 & 79,841 & 10,077 & 31,493 & 38,271 & 3,532 & 607 & 1,556 & 1,369 \\
\hline Wisconsin & 4,170 & 1,704 & 1,046 & 1,420 & 45,483 & 10,130 & 11,647 & 23,706 & 2,317 & 731 & 697 & 890 \\
\hline Great Plains & 2,999 & 355 & 708 & 1,936 & 42,855 & 2,053 & 9,770 & 31,032 & 1,827 & 147 & 463 & 1,216 \\
\hline Kansas & 1,362 & 231 & 417 & 714 & 19,316 & 1,395 & 5,837 & 12,084 & 813 & 93 & 274 & 446 \\
\hline Nebraska & 961 & 75 & 214 & 672 & 13,383 & 385 & 2,783 & 10,215 & 596 & 32 & 141 & 424 \\
\hline North Dakota & 307 & 22 & 32 & 254 & 4,500 & 138 & 452 & 3,910 & 189 & 9 & 21 & 160 \\
\hline South Dakota & 369 & 27 & 46 & 297 & 5,657 & 135 & 699 & 4,823 & 228 & 13 & 28 & 187 \\
\hline South & 34,559 & 10,189 & 12,270 & 12,100 & 498,420 & 93,753 & 188,420 & 216,247 & 22,150 & 6,301 & 8,194 & 7,656 \\
\hline Southcentral & 13,992 & 3,644 & 4,601 & 5,746 & 209,935 & 36,629 & 70,909 & 102,397 & 8,615 & 1,974 & 3,039 & 3,602 \\
\hline Arkansas & 1,395 & 628 & 255 & 513 & 16,680 & 3,349 & 4,135 & 9,197 & 675 & 195 & 166 & 315 \\
\hline Louisiana & 1,069 & 157 & 265 & 647 & 19,617 & 1,762 & 4,785 & 13,070 & 679 & 100 & 173 & 406 \\
\hline New Mexico & 520 & 87 & 207 & 226 & 8,739 & 660 & 3,437 & 4,642 & 353 & 72 & 137 & 145 \\
\hline Oklahoma & 1,352 & 449 & 322 & 580 & 24,603 & 5,498 & 7,158 & 11,947 & 819 & 247 & 212 & 359 \\
\hline Texas & 9,656 & 2,324 & 3,551 & 3,781 & 140,295 & 25,360 & 51,394 & 63,541 & 6,088 & 1,360 & 2,351 & 2,377 \\
\hline Southeast & 20,568 & 6,545 & 7,669 & 6,354 & 288,486 & 57,124 & 117,511 & 113,850 & 13,535 & 4,327 & 5,155 & 4,054 \\
\hline Alabama & 1,681 & 437 & 668 & 576 & 26,804 & 4,521 & 10,617 & 11,666 & 1,148 & 353 & 434 & 360 \\
\hline Florida & 9,997 & 3,025 & 4,051 & 2,921 & 147,795 & 32,966 & 62,632 & 52,197 & 7,076 & 2,463 & 2,747 & 1,866 \\
\hline Georgia & 4,726 & 1,143 & 1,782 & 1,800 & 62,493 & 7,362 & 25,620 & 29,511 & 3,020 & 644 & 1,213 & 1,162 \\
\hline Mississippi & 977 & 296 & 190 & 491 & 14,236 & 1,789 & 3,309 & 9,138 & 548 & 120 & 122 & 306 \\
\hline South Carolina & 3,187 & 1,644 & 978 & 565 & 37,157 & 10,486 & 15,333 & 11,337 & 1,745 & 747 & 638 & 359 \\
\hline West & 37,326 & 8,829 & 16,335 & 12,162 & 485,467 & 78,612 & 219,879 & 186,976 & 24,830 & 5,859 & 11,112 & $\mathbf{7 , 8 5 9}$ \\
\hline Mountain & 9,824 & 1,473 & 4,750 & 3,601 & 132,982 & 10,557 & 64,279 & 58,146 & 6,449 & 954 & 3,185 & 2,309 \\
\hline Arizona & 3,206 & 826 & 1,508 & 873 & 43,882 & 5,796 & 23,198 & 14,888 & 2,081 & 506 & 1,013 & 563 \\
\hline Colorado & 3,085 & 294 & 1,612 & 1,179 & 37,630 & 1,554 & 19,059 & 17,017 & 2,019 & 178 & 1,083 & 758 \\
\hline Idaho & 853 & 107 & 250 & 496 & 12,000 & 923 & 3,534 & 7,543 & 576 & 91 & 164 & 320 \\
\hline Montana & 357 & 57 & 68 & 232 & 5,988 & 492 & 931 & 4,564 & 219 & 31 & 43 & 145 \\
\hline Nevada & 1,248 & 16 & 929 & 303 & 17,324 & 121 & 12,433 & 4,770 & 844 & 13 & 633 & 198 \\
\hline Utah & 901 & 165 & 316 & 420 & 13,577 & 1,614 & 4,388 & 7,575 & 600 & 130 & 206 & 264 \\
\hline Wyoming & 174 & 8 & 68 & 98 & 2,581 & 57 & 736 & 1,788 & 109 & 4 & 44 & 61 \\
\hline Pacific & 27,502 & 7,356 & 11,585 & 8,561 & 352,485 & 68,055 & 155,600 & 128,830 & 18,382 & 4,905 & 7,927 & 5,550 \\
\hline Alaska & 159 & 18 & 53 & 88 & 2,110 & 146 & 467 & 1,497 & 104 & 10 & 36 & 58 \\
\hline California & 20,362 & 4,736 & 9,371 & 6,255 & 253,977 & 36,236 & 126,428 & 91,313 & 13,656 & 3,165 & 6,429 & 4,063 \\
\hline Hawaii & 745 & 254 & 320 & 171 & 11,166 & 3,394 & 4,492 & 3,281 & 531 & 200 & 220 & 112 \\
\hline Oregon & 3,173 & 1,711 & 660 & 802 & 43,980 & 21,632 & 9,171 & 13,177 & 2,010 & 1,048 & 448 & 515 \\
\hline Washington & 3,064 & 636 & 1,181 & 1,246 & 41,251 & 6,647 & 15,042 & 19,561 & 2,080 & 482 & 795 & 803 \\
\hline Total All Regions & 147,828 & 34,578 & 57,774 & 55,475 & $1,964,339$ & 300,677 & 753,557 & 910,104 & 95,084 & 20,796 & 39,013 & 35,275 \\
\hline
\end{tabular}

* Values expressed in 2004 dollars (GDP Implicit Price Deflator, US Dept. Commerce) 


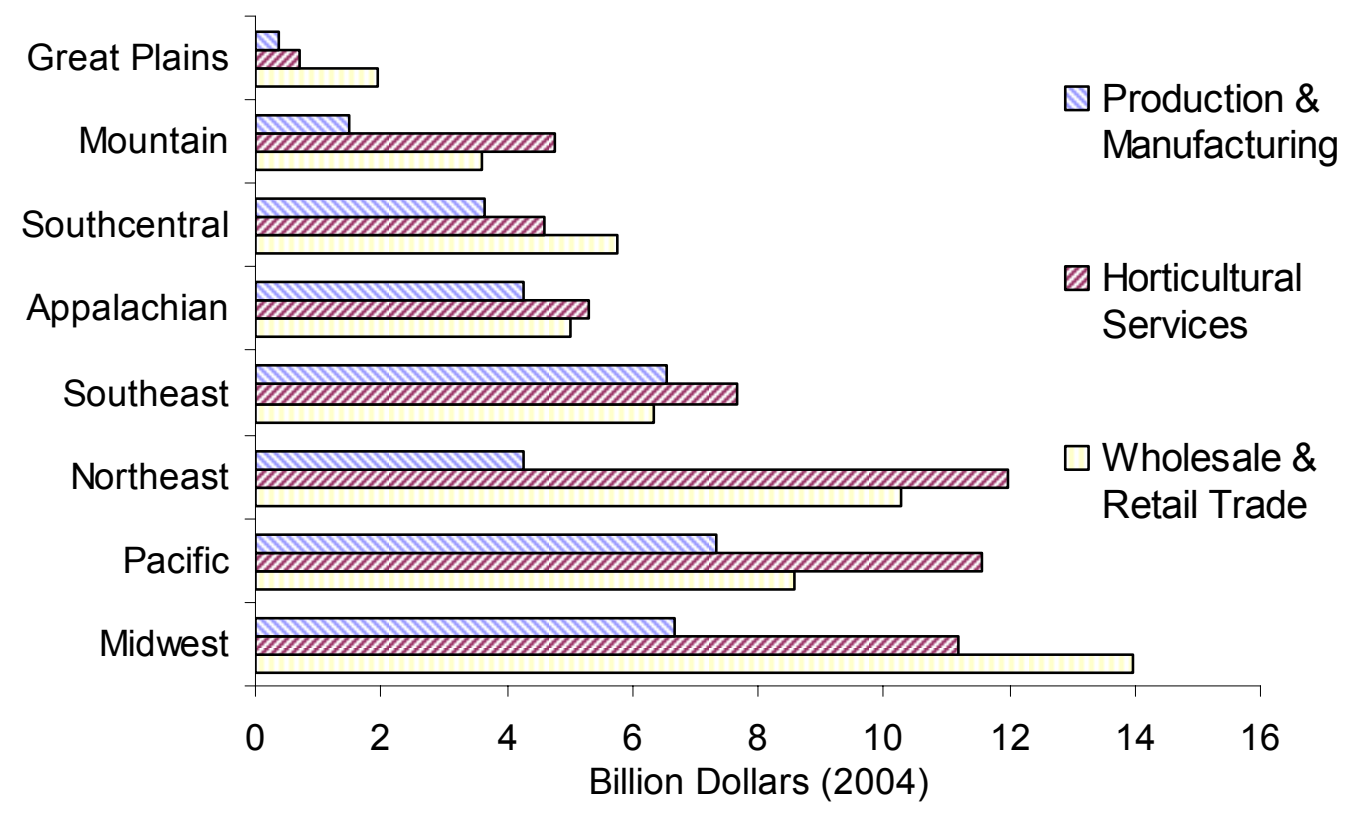

Figure 3-1. Output Impacts of the U.S. Green Industry by Region and Industry Group, 2002

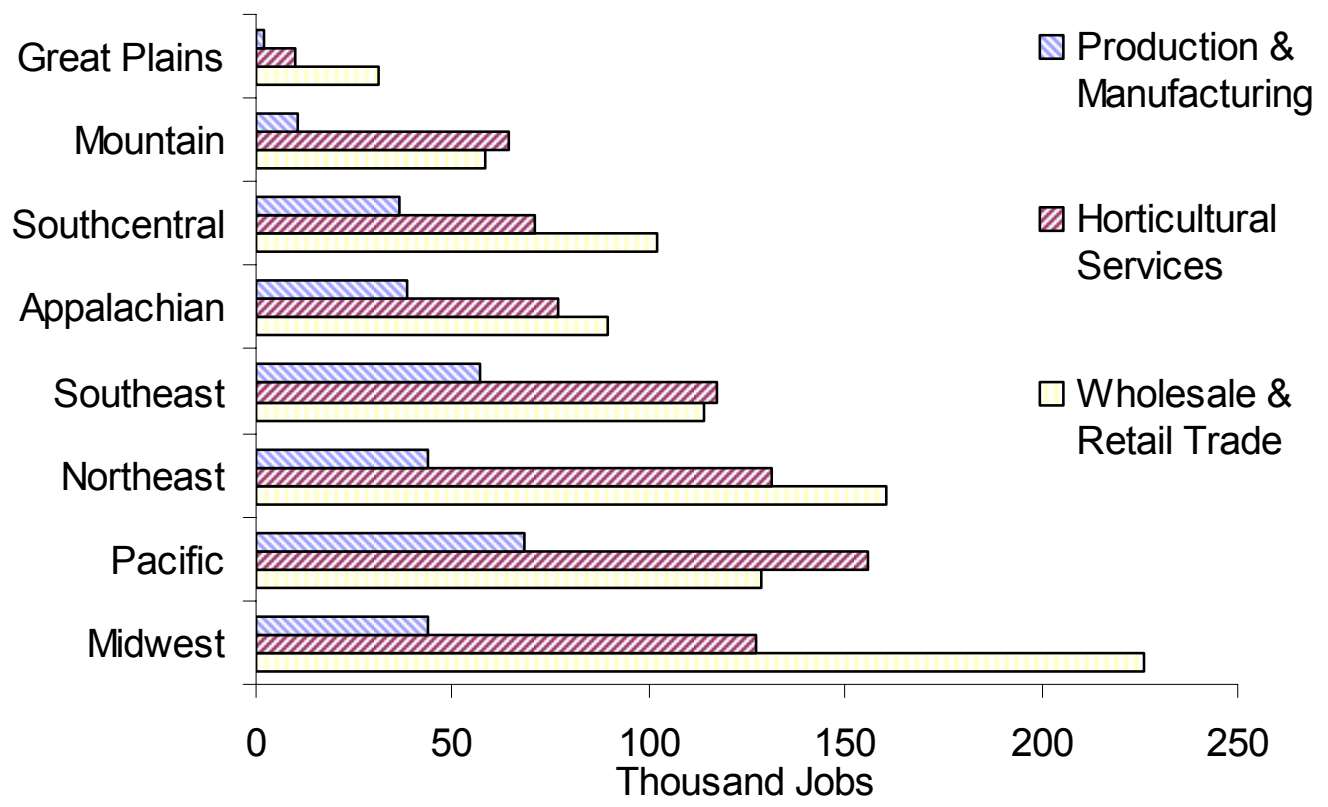

Figure 3-2. Employment Impacts of the U.S. Green Industry by Region and Industry Group, 2002 


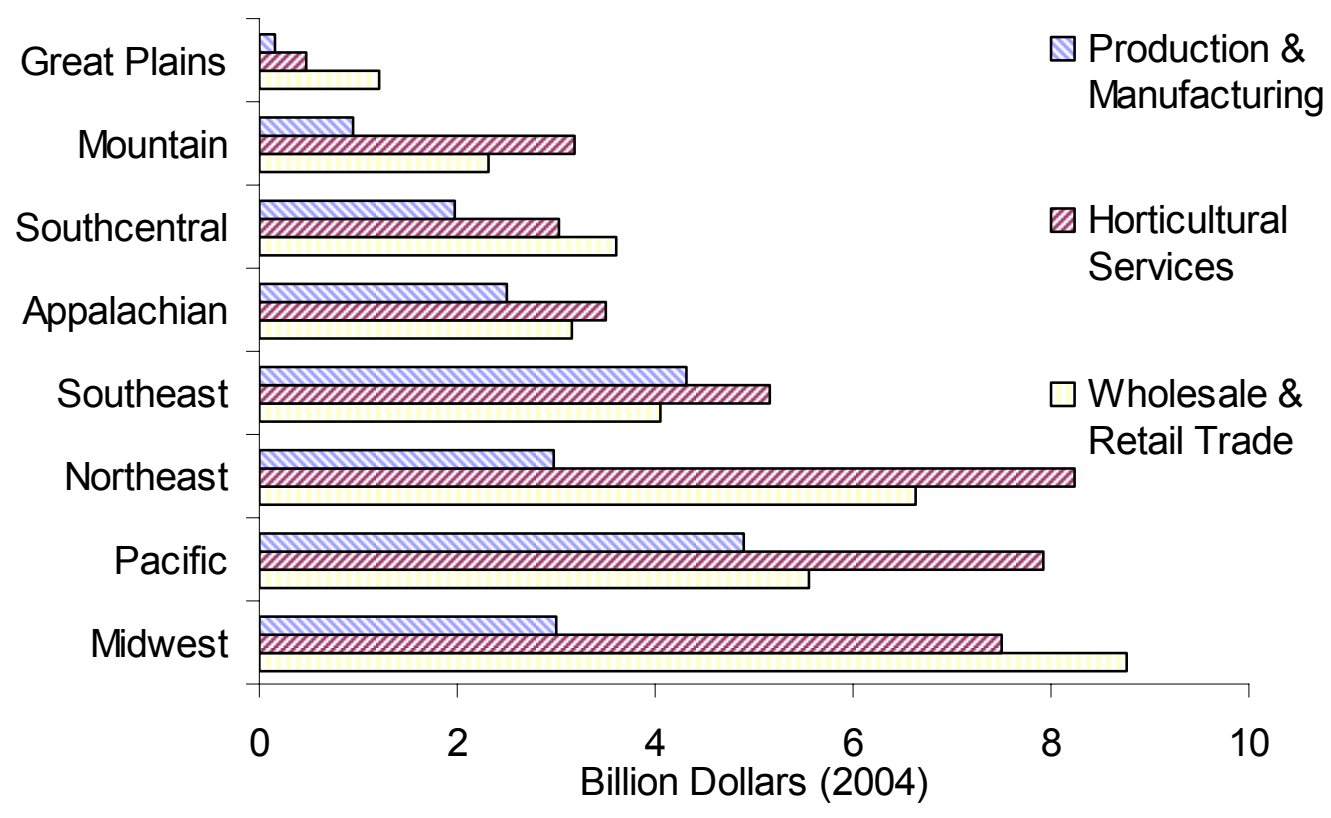

Figure 3-3. Value added Impacts of the U.S. Green Industry by Region and Industry Group, 2002 
Table 3-3. Output Impacts of the U.S. Green Industry by Sector and State, 2002

\begin{tabular}{|c|c|c|c|c|c|c|c|c|c|c|c|c|}
\hline State & $\begin{array}{l}\text { Nursery } \\
\text { \& Green- } \\
\text { house }\end{array}$ & $\begin{array}{l}\text { Lawn \& } \\
\text { Garden } \\
\text { Equip. \& } \\
\text { Grnhse. } \\
\text { Mfg }\end{array}$ & $\begin{array}{c}\text { Land- } \\
\text { scaping } \\
\text { Services }\end{array}$ & $\begin{array}{l}\text { Land- } \\
\text { scape } \\
\text { Archi- } \\
\text { tecture }\end{array}$ & $\begin{array}{c}\text { Horticul- } \\
\text { tural } \\
\text { Whole- } \\
\text { salers }\end{array}$ & $\begin{array}{l}\text { Garden } \\
\text { Equip- } \\
\text { ment } \\
\text { Whole- } \\
\text { sale }\end{array}$ & $\begin{array}{c}\text { Lawn \& } \\
\text { Garden } \\
\text { Stores }\end{array}$ & $\begin{array}{c}\text { Building } \\
\text { Material } \\
\text { Supply } \\
\text { Stores }\end{array}$ & Florists & $\begin{array}{c}\text { Food } \\
\& \\
\text { beverage } \\
\text { stores }\end{array}$ & $\begin{array}{l}\text { General } \\
\text { merch- } \\
\text { andise } \\
\text { stores }\end{array}$ & $\begin{array}{c}\text { Total } \\
\text { All } \\
\text { Sectors }\end{array}$ \\
\hline \multicolumn{13}{|c|}{ Output Impacts (\$Mn)* } \\
\hline Alabama & 411 & 26 & 627 & 41 & 26 & 47 & 189 & 117 & 75 & 24 & 98 & 1,681 \\
\hline Alaska & 18 & 0 & 46 & 6 & 2 & 0 & 19 & 29 & 12 & 5 & 21 & 159 \\
\hline Arizona & 596 & 230 & 1,393 & 115 & 56 & 49 & 311 & 194 & 89 & 60 & 114 & 3,206 \\
\hline Arkansas & 73 & 555 & 240 & 15 & 7 & 75 & 232 & 64 & 59 & 11 & 66 & 1,395 \\
\hline California & 4,470 & 266 & 8,269 & 1,102 & 485 & 297 & 2,517 & 1,210 & 725 & 355 & 665 & 20,362 \\
\hline Colorado & 289 & 5 & 1,408 & 204 & 42 & 76 & 521 & 247 & 126 & 51 & 117 & 3,085 \\
\hline Connecticut & 453 & 0 & 1,080 & 62 & 29 & 34 & 329 & 159 & 114 & 35 & 54 & 2,350 \\
\hline Delaware & 53 & 0 & 213 & 16 & 6 & 16 & 60 & 31 & 28 & 6 & 19 & 448 \\
\hline Florida & 3,006 & 19 & 3,801 & 250 & 446 & 119 & 748 & 617 & 439 & 153 & 399 & 9,997 \\
\hline Georgia & 567 & 577 & 1,664 & 118 & 101 & 156 & 690 & 384 & 198 & 67 & 204 & 4,726 \\
\hline Hawaii & 254 & 0 & 274 & 46 & 10 & 7 & 41 & 30 & 41 & 10 & 31 & 745 \\
\hline Idaho & 107 & 0 & 239 & 11 & 3 & 52 & 337 & 46 & 21 & 8 & 29 & 853 \\
\hline Illinois & 432 & 526 & 2,621 & 256 & 224 & 284 & 1,288 & 479 & 427 & 82 & 278 & 6,897 \\
\hline Indiana & 276 & 246 & 1,096 & 44 & 25 & 106 & 654 & 211 & 166 & 33 & 152 & 3,010 \\
\hline Iowa & 106 & 28 & 306 & 23 & 7 & 183 & 569 & 94 & 60 & 20 & 62 & 1,459 \\
\hline Kansas & 114 & 118 & 378 & 39 & 16 & 119 & 357 & 85 & 57 & 17 & 63 & 1,362 \\
\hline Kentucky & 132 & 6 & 353 & 20 & 16 & 45 & 385 & 102 & 87 & 21 & 90 & 1,257 \\
\hline Louisiana & 149 & 7 & 244 & 21 & 14 & 49 & 271 & 110 & 79 & 24 & 100 & 1,069 \\
\hline Maine & 52 & 4 & 227 & 26 & 2 & 10 & 81 & 44 & 30 & 11 & 23 & 509 \\
\hline Maryland & 601 & 3 & 1,720 & 87 & 54 & 47 & 427 & 222 & 196 & 60 & 107 & 3,524 \\
\hline Massachusetts & 199 & 1 & 1,558 & 230 & 73 & 31 & 417 & 291 & 263 & 74 & 102 & 3,239 \\
\hline Michigan & 910 & 211 & 1,561 & 236 & 65 & 117 & 756 & 380 & 286 & 63 & 258 & 4,845 \\
\hline Minnesota & 310 & 247 & 877 & 56 & 40 & 220 & 728 & 239 & 207 & 43 & 134 & 3,099 \\
\hline Mississippi & 56 & 241 & 168 & 22 & 15 & 43 & 249 & 60 & 48 & 11 & 65 & 977 \\
\hline Missouri & 142 & 221 & 676 & 27 & 33 & 107 & 674 & 216 & 169 & 37 & 186 & 2,488 \\
\hline Montana & 57 & 0 & 62 & 6 & 3 & 32 & 122 & 29 & 22 & 6 & 18 & 357 \\
\hline Nebraska & 40 & 35 & 199 & 16 & 4 & 127 & 391 & 61 & 39 & 11 & 37 & 961 \\
\hline Nevada & 14 & 1 & 897 & 32 & 9 & 19 & 109 & 66 & 35 & 18 & 48 & 1,248 \\
\hline New Hampshire & 101 & 3 & 298 & 18 & 8 & 13 & 121 & 70 & 50 & 13 & 35 & 729 \\
\hline New Jersey & 562 & 18 & 1,982 & 146 & 198 & 54 & 443 & 326 & 259 & 93 & 131 & 4,210 \\
\hline New Mexico & 87 & 0 & 184 & 23 & 3 & 12 & 80 & 53 & 26 & 10 & 41 & 520 \\
\hline New York & 534 & 217 & 1,693 & 194 & 156 & 100 & 927 & 528 & 509 & 142 & 265 & 5,265 \\
\hline North Carolina & 1,638 & 118 & 1,803 & 122 & 41 & 152 & 592 & 311 & 160 & 52 & 165 & 5,155 \\
\hline North Dakota & 18 & 4 & 31 & 1 & 1 & 95 & 109 & 21 & 13 & 3 & 11 & 307 \\
\hline Ohio & 756 & 547 & 2,248 & 107 & 159 & 255 & 821 & 355 & 294 & 78 & 237 & 5,855 \\
\hline Oklahoma & 429 & 20 & 305 & 17 & 19 & 46 & 252 & 86 & 74 & 15 & 88 & 1,352 \\
\hline Oregon & 1,693 & 18 & 602 & 58 & 28 & 58 & 407 & 114 & 66 & 29 & 100 & 3,173 \\
\hline Pennsylvania & 1,321 & 56 & 1,909 & 183 & 76 & 97 & 830 & 407 & 364 & 105 & 242 & 5,589 \\
\hline Rhode Island & 67 & 0 & 226 & 7 & 9 & 3 & 18 & 28 & 26 & 7 & 12 & 403 \\
\hline South Carolina & 445 & 1,199 & 933 & 44 & 32 & 29 & 220 & 120 & 63 & 23 & 78 & 3,187 \\
\hline South Dakota & 23 & 4 & 41 & 4 & 8 & 48 & 181 & 24 & 15 & 5 & 14 & 369 \\
\hline Tennessee & 548 & 1,193 & 910 & 65 & 26 & 77 & 524 & 198 & 137 & 33 & 142 & 3,854 \\
\hline Texas & 2,276 & 48 & 3,179 & 372 & 169 & 276 & 1,505 & 703 & 454 & 157 & 517 & 9,656 \\
\hline Utah & 160 & 5 & 302 & 14 & 9 & 28 & 174 & 94 & 39 & 18 & 57 & 901 \\
\hline Vermont & 34 & 3 & 111 & 9 & 3 & 10 & 75 & 26 & 20 & 6 & 6 & 302 \\
\hline Virginia & 373 & 211 & 1,760 & 109 & 29 & 73 & 647 & 244 & 236 & 57 & 174 & 3,914 \\
\hline Washington & 630 & 6 & 1,096 & 85 & 61 & 78 & 606 & 196 & 113 & 52 & 140 & 3,064 \\
\hline West Virginia & 40 & 0 & 141 & 6 & 4 & 6 & 62 & 37 & 35 & 7 & 32 & 371 \\
\hline Wisconsin & 424 & 1,281 & 957 & 89 & 25 & 154 & 751 & 214 & 129 & 35 & 112 & 4,170 \\
\hline Wyoming & 8 & 0 & 62 & 5 & 2 & 14 & 39 & 13 & 18 & 3 & 9 & 174 \\
\hline Total All States & 26,053 & 8,526 & 52,971 & 4,803 & 2,879 & 4,146 & 22,859 & 9,982 & 7,195 & 2,263 & 6,150 & 147,828 \\
\hline
\end{tabular}

* Values expressed in 2004 dollars (GDP Implicit Price Deflator, US Dept. Commerce). 


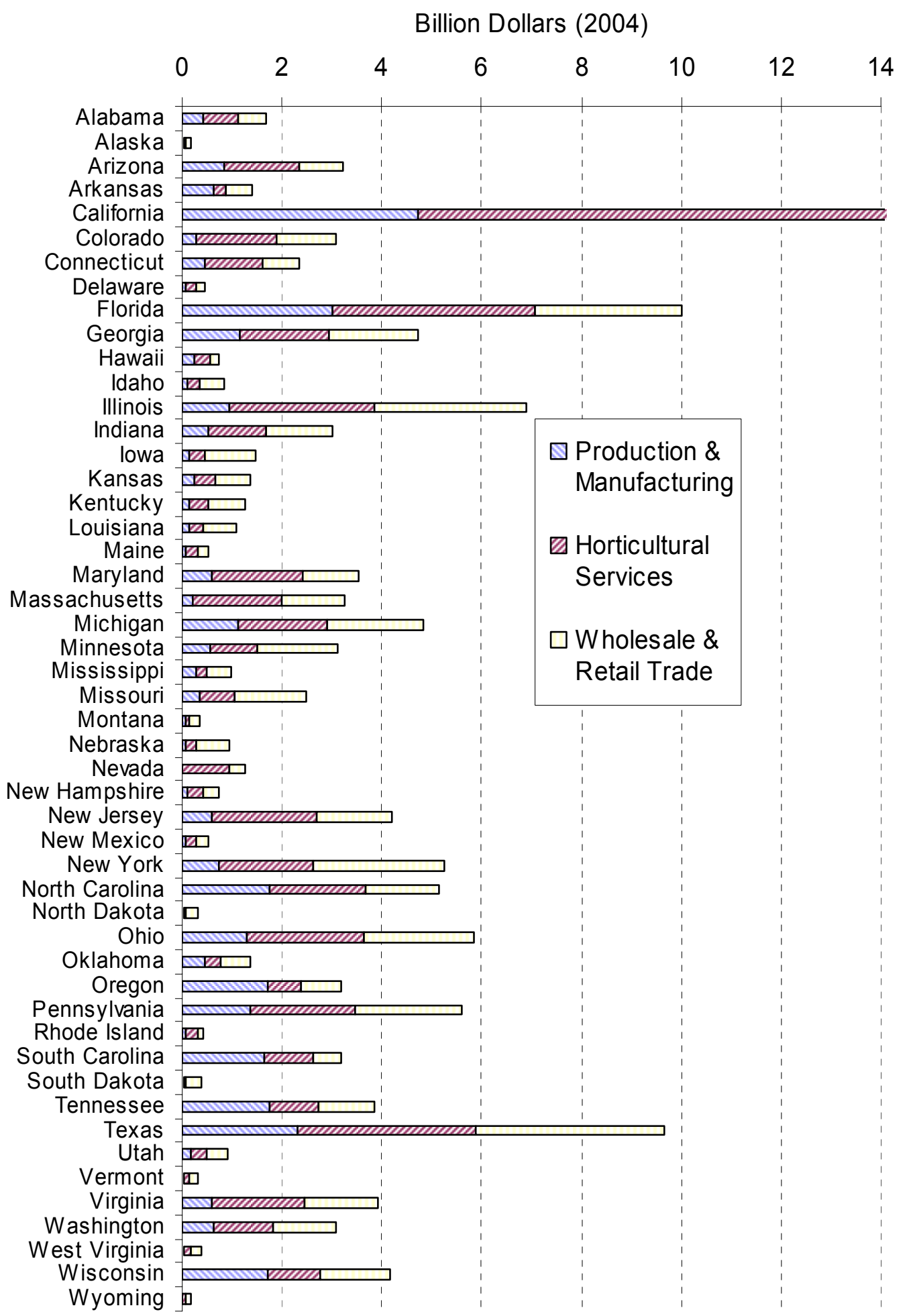

Figure 3-4. Output Impacts of the U.S. Green Industry by State and Industry Group, 2002 
Table 3-4. Employment Impacts of the U.S. Green Industry by Sector and State, 2002

\begin{tabular}{|c|c|c|c|c|c|c|c|c|c|c|c|c|}
\hline State & $\begin{array}{c}\text { Nursery } \\
\& \\
\text { Green- } \\
\text { house }\end{array}$ & $\begin{array}{l}\text { Lawn \& } \\
\text { Garden } \\
\text { Equip. \& } \\
\text { Grnhse. } \\
\text { Mfg }\end{array}$ & $\begin{array}{c}\text { Land- } \\
\text { scaping } \\
\text { Services }\end{array}$ & $\begin{array}{l}\text { Land- } \\
\text { scape } \\
\text { Architec- } \\
\text { ture }\end{array}$ & $\begin{array}{c}\text { Horticul- } \\
\text { tural } \\
\text { Whole- } \\
\text { salers }\end{array}$ & $\begin{array}{c}\text { Garden } \\
\text { Equip- } \\
\text { ment } \\
\text { Whole- } \\
\text { sale }\end{array}$ & $\begin{array}{c}\text { Lawn \& } \\
\text { Garden } \\
\text { Stores }\end{array}$ & $\begin{array}{c}\text { Building } \\
\text { Material } \\
\text { Supply } \\
\text { Stores }\end{array}$ & Florists & $\begin{array}{c}\text { Food \& } \\
\text { beverage } \\
\text { stores }\end{array}$ & $\begin{array}{c}\text { General } \\
\text { merchan- } \\
\text { dise stores }\end{array}$ & $\begin{array}{l}\text { Total All } \\
\text { Sectors }\end{array}$ \\
\hline \multicolumn{12}{|c|}{ Employment Impacts (jobs) } & \\
\hline Alabama & 4,521 & 137 & 10,027 & 590 & 809 & 529 & 3,786 & 1,753 & 2,610 & 457 & 1,722 & 26,804 \\
\hline Alaska & 143 & 3 & 400 & 68 & 53 & 3 & 307 & 381 & 376 & 80 & 297 & 2,110 \\
\hline Arizona & 4,781 & 1,015 & 21,970 & 1,228 & 1,534 & 454 & 4,945 & 2,548 & 2,923 & 785 & 1,700 & 43,882 \\
\hline Arkansas & 733 & 2,616 & 3,980 & 155 & 257 & 753 & 3,844 & 929 & 2,014 & 233 & 1,167 & 16,680 \\
\hline California & 35,268 & 968 & 115,134 & 11,294 & 11,793 & 2,536 & 31,352 & 13,822 & 19,131 & 4,195 & 8,484 & 253,977 \\
\hline Colorado & 1,529 & 26 & 17,234 & 1,825 & 1,095 & 746 & 6,990 & 2,697 & 3,283 & 636 & 1,571 & 37,630 \\
\hline Connecticut & 4,796 & 11 & 10,691 & 523 & 655 & 264 & 4,479 & 1,685 & 2,604 & 497 & 822 & 27,026 \\
\hline Delaware & 375 & 0 & 3,010 & 184 & 179 & 170 & 876 & 430 & 716 & 99 & 320 & 6,359 \\
\hline Florida & 32,821 & 145 & 59,935 & 2,697 & 9,868 & 1,195 & 12,661 & 8,175 & 11,951 & 2,477 & 5,870 & 147,795 \\
\hline Georgia & 4,690 & 2,672 & 24,250 & 1,370 & 2,169 & 1,560 & 11,400 & 4,687 & 5,495 & 1,156 & 3,045 & 62,493 \\
\hline Hawaii & 3,394 & 0 & 4,038 & 454 & 343 & 49 & 685 & 440 & 1,153 & 155 & 456 & 11,166 \\
\hline Idaho & 919 & 4 & 3,404 & 130 & 99 & 539 & 4,559 & 739 & 950 & 154 & 502 & 12,000 \\
\hline Illinois & 2,555 & 2,110 & 24,818 & 1,909 & 4,327 & 2,597 & 15,641 & 5,378 & 10,571 & 1,217 & 3,986 & 75,110 \\
\hline Indiana & 2,192 & 1,215 & 14,155 & 477 & 793 & 1,018 & 10,323 & 2,914 & 5,477 & 627 & 2,524 & 41,714 \\
\hline Iowa & 646 & 176 & 4,158 & 213 & 252 & 1,844 & 8,092 & 1,391 & 2,582 & 407 & 1,059 & 20,820 \\
\hline Kansas & 851 & 544 & 5,330 & 507 & 496 & 1,150 & 5,791 & 1,159 & 2,08 & 327 & 1,076 & 19,317 \\
\hline Kentucky & 1,911 & 30 & 5,370 & 274 & 538 & 494 & 6,725 & 1,474 & 2,83 & 430 & 1,571 & 21,649 \\
\hline Louisiana & 1,712 & 50 & 4,414 & 370 & 539 & 602 & 5,256 & 1,730 & 2,70 & 497 & 1,746 & 19,617 \\
\hline Maine & 642 & 22 & 2,998 & 254 & 58 & 117 & 1,508 & 621 & 995 & 218 & 391 & 7,826 \\
\hline Maryland & 5,650 & 16 & 21,702 & 894 & 1,293 & 457 & 6,641 & 2,607 & 4,905 & 817 & 1,744 & 46,725 \\
\hline Massachusetts & 3,406 & 4 & 14,659 & 1,890 & 1,474 & 240 & 5,038 & 2,978 & 5,364 & 1,046 & 1,453 & 37,553 \\
\hline Michigan & 8,526 & 743 & 16,066 & 2,045 & 1,576 & 1,187 & 10,617 & 4,675 & & 1,062 & 3,893 & 58,745 \\
\hline Minnesota & 1,983 & 1,169 & 5,891 & 510 & 1,039 & 2,036 & 10,018 & 2,789 & & 742 & 1,972 & 34,018 \\
\hline Mississippi & 657 & 1,132 & 995 & 314 & 598 & 439 & 3,928 & 951 & 1,826 & 252 & 1,145 & 14,236 \\
\hline Missouri & 1,639 & 901 & 9,667 & 327 & 1,244 & 1,133 & 12,056 & 2,929 & 4,558 & 619 & 2,618 & 37,690 \\
\hline Montana & 491 & 1 & 872 & 60 & 86 & 375 & 2,372 & 465 & 861 & 105 & 301 & 5,988 \\
\hline Nebraska & 159 & 226 & 2,626 & 157 & 162 & 1,305 & 5,576 & 871 & 1,426 & 236 & 639 & 13,383 \\
\hline Nevada & 110 & 11 & 12,067 & & 186 & 190 & 1,745 & 801 & 932 & 236 & 679 & 17,324 \\
\hline New Hampshire & 1,444 & 26 & 3,428 & 157 & 160 & 128 & 1,844 & 852 & & 231 & 532 & 10,153 \\
\hline New Jersey & 6,968 & 74 & 21,878 & 1,340 & 3,590 & 444 & 5,907 & 3,461 & 6,095 & 1,247 & 1,925 & 52,929 \\
\hline Tew Mexico & 656 & 4 & 2,410 & & 100 & 143 & 1,772 & 739 & & 173 & 676 & 8,028 \\
\hline New York & 4,525 & 819 & 198 & & 3,093 & 920 & 11,640 & 5,890 & 10,688 & 2,113 & 3,721 & 62,113 \\
\hline North Carolina & 12,478 & 514 & 27,658 & 1,414 & 1,199 & 1,141 & 10,365 & 4,018 & 4,947 & 921 & 2,818 & 67,472 \\
\hline North Dakota & 119 & 19 & 442 & 10 & 32 & 1,059 & 1,652 & 314 & 552 & 76 & 225 & 4,500 \\
\hline Ohio & 7,676 & 2,401 & 30,400 & 1,093 & 3,416 & 2,787 & 13,103 & 4,645 & & 1,389 & 3,953 & 79,841 \\
\hline Oklahoma & 5,405 & 94 & 6,909 & 249 & 674 & 510 & 4,951 & 1,245 & 2,670 & 318 & 1,579 & 24,603 \\
\hline Oregon & 21,554 & 78 & 8,436 & 735 & 719 & 546 & 6,381 & 1,388 & 2,249 & 460 & 1,435 & 43,980 \\
\hline Pennsylvania & 13,562 & 241 & 23,589 & 1,844 & 2,167 & 944 & 13,186 & 4,859 & 9,845 & 1,776 & 3,816 & 75,829 \\
\hline Rhode Island & 895 & 0 & 2,404 & 70 & 214 & 30 & 265 & 331 & 752 & 121 & 209 & 5,289 \\
\hline & 4,882 & 5,605 & 14,770 & 563 & 936 & 330 & 4,249 & 1,769 & 2,244 & 479 & 1,329 & 37,157 \\
\hline South Dakota & 109 & 26 & 647 & 52 & 240 & 497 & 2,693 & 379 & 647 & 112 & 255 & 5,657 \\
\hline Tennessee & 10,757 & 5,847 & 12,865 & 929 & 791 & 748 & 9,437 & 2,521 & 3,910 & 636 & 2,373 & 50,812 \\
\hline Texas & 25,038 & 322 & 36,804 & 3,959 & 4,445 & 2,768 & 25,386 & 8,645 & 12,248 & 2,374 & 7,675 & 129,664 \\
\hline Utah & 1,583 & 31 & 4,238 & 150 & 286 & 347 & 3,175 & 1,227 & 1,347 & 310 & 885 & 13,577 \\
\hline Vermont & 310 & 12 & 1,264 & 81 & 62 & 115 & 1,196 & 334 & 609 & 125 & 119 & 4,225 \\
\hline Virginia & 4,956 & 815 & 24,768 & 1,292 & 863 & 762 & 11,014 & 3,030 & 5,914 & 879 & 2,612 & 56,905 \\
\hline Washington & 6,616 & 31 & 14,196 & 846 & 1,577 & 730 & 8,956 & 2,374 & 3,320 & 720 & 1,885 & 41,251 \\
\hline West Virginia & 1,087 & 4 & 2,245 & 58 & 146 & 61 & 1,328 & 582 & 1,316 & 183 & 620 & 7,631 \\
\hline Wisconsin & 3,774 & 6,355 & 10,765 & 882 & 691 & 1,482 & 11,567 & 2,795 & 4,634 & 654 & 1,883 & 45,483 \\
\hline Wyoming & 49 & 8 & 682 & 53 & 55 & 143 & 639 & 173 & 552 & 60 & 166 & 2,581 \\
\hline Total All States & 261,408 & 39,270 & 689,854 & 48,683 & 68,969 & 40,617 & 347,916 & 123,591 & 200,451 & 35,117 & 93,443 & $1,949,321$ \\
\hline
\end{tabular}




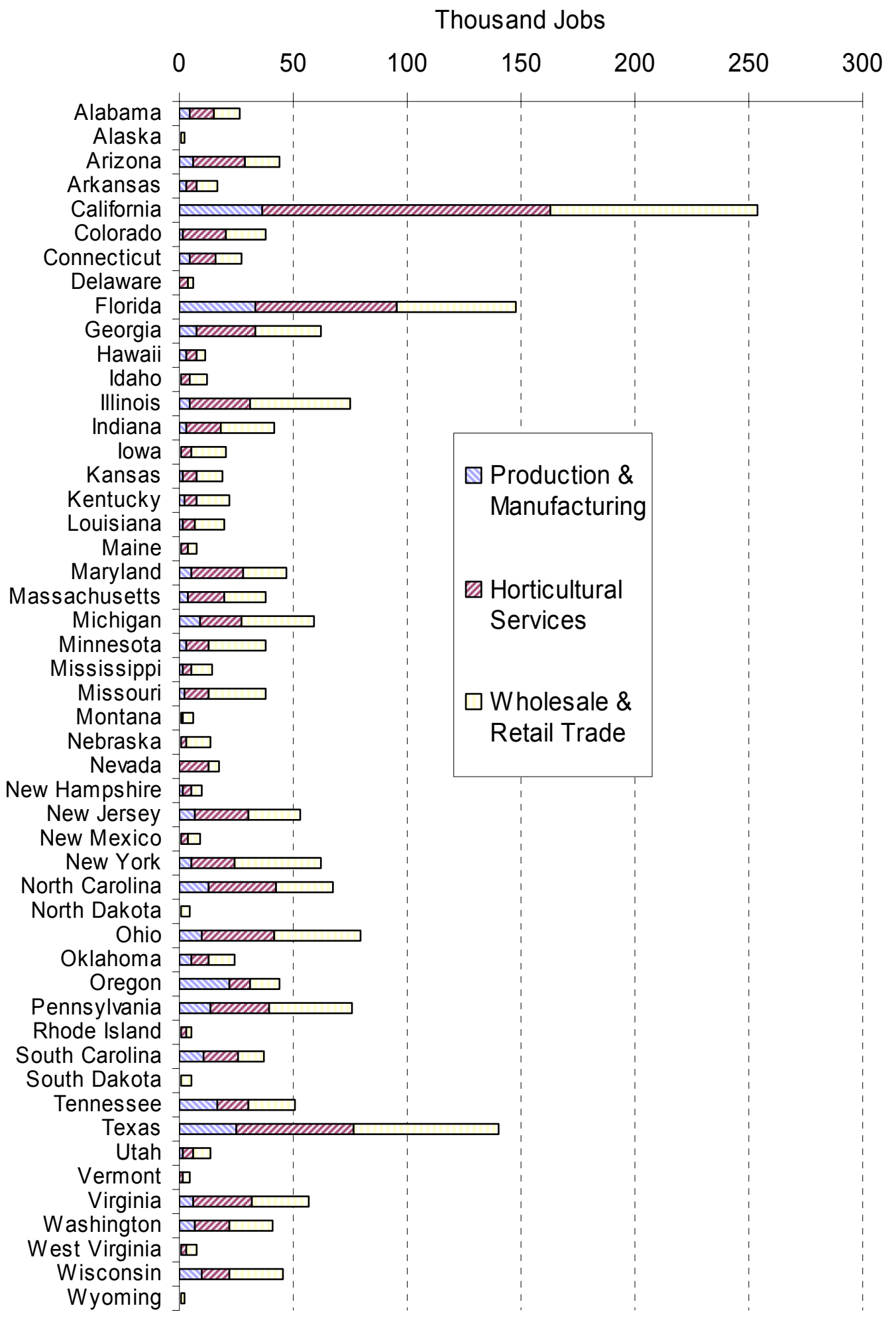

Figure 3-5. Employment Impacts of the U.S. Green Industry by State and Industry Group, 2002 
Table 3-5. Value Added Impacts of the U.S. Green Industry by Sector and State, 2002

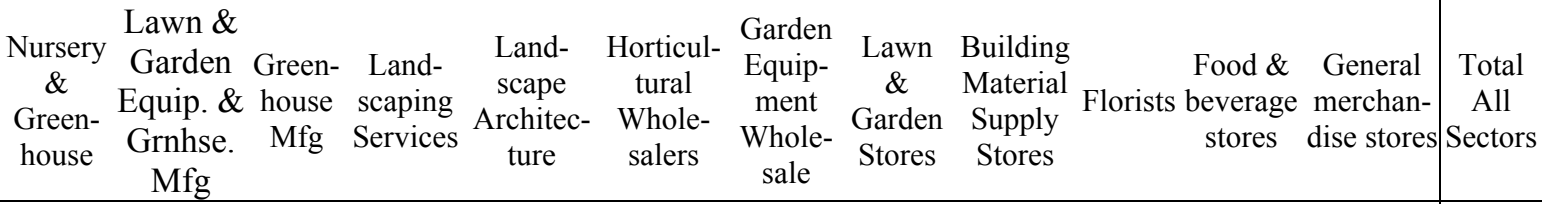

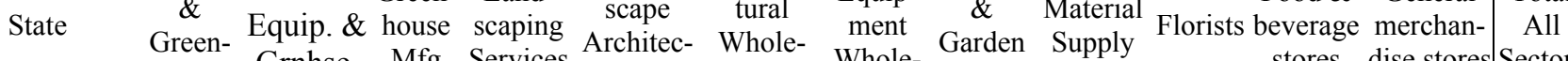

house Grnhse. Mfg Services ture salers Whole- Stores Stores stores dise stores Sectors

\begin{tabular}{|c|c|c|c|c|c|c|c|c|c|c|c|c|c|}
\hline \multicolumn{14}{|c|}{ Value Added Impacts (\$Mn)* } \\
\hline Alabama & 345 & 9 & 4 & 405 & 29 & 17 & 31 & 122 & 75 & 38 & 14 & 63 & 1,148 \\
\hline Alaska & 10 & 0 & 0 & 31 & 5 & 1 & 0 & 13 & 19 & 6 & 3 & 14 & 104 \\
\hline Arizona & 435 & 71 & 2 & 929 & 84 & 37 & 32 & 204 & 127 & 51 & 38 & 74 & 2,081 \\
\hline Arkansas & 58 & 137 & 2 & 154 & 11 & 4 & 49 & 146 & 40 & 28 & 6 & 41 & 675 \\
\hline California & 3,079 & 86 & 10 & 5,644 & 785 & 324 & 199 & 1,657 & 797 & 424 & 226 & 437 & 13,656 \\
\hline Colorado & 177 & 2 & 1 & 939 & 144 & 28 & 50 & 340 & 161 & 70 & 32 & 76 & 2,019 \\
\hline Connecticut & 375 & 0 & 0 & 742 & 46 & 19 & 23 & 223 & 107 & 66 & 23 & 36 & 1,659 \\
\hline Delaware & 44 & 0 & 0 & 138 & 11 & 4 & 10 & 39 & 20 & 15 & 4 & 13 & 297 \\
\hline Florida & 2,456 & 7 & 5 & 2,562 & 185 & 294 & 79 & 488 & 402 & 251 & 92 & 259 & 7,076 \\
\hline Georgia & 468 & 176 & 5 & 1,127 & 86 & 67 & 103 & 453 & 252 & 113 & 41 & 133 & 3,020 \\
\hline Hawaii & 200 & 0 & 0 & 186 & 33 & 7 & 5 & 28 & 21 & 24 & 7 & 21 & 531 \\
\hline Idaho & 91 & 0 & 0 & 156 & 8 & 2 & 34 & 220 & 30 & 10 & 5 & 19 & 576 \\
\hline Illinois & 268 & 162 & 7 & 1,786 & 186 & 147 & 187 & 826 & 308 & 238 & 50 & 177 & 4,335 \\
\hline Indiana & 156 & 73 & 4 & 714 & 32 & 17 & 70 & 412 & 133 & 84 & 19 & 95 & 1,804 \\
\hline Iowa & 53 & 10 & 2 & 199 & 17 & 5 & 121 & 362 & 60 & 30 & 12 & 39 & 906 \\
\hline Kansas & 55 & 39 & 1 & 246 & 27 & 11 & 79 & 225 & 53 & 29 & 10 & 40 & 813 \\
\hline Kentucky & 110 & 2 & 1 & 230 & 15 & 11 & 30 & 245 & 65 & 44 & 12 & 57 & 821 \\
\hline Louisiana & 97 & 3 & 2 & 158 & 15 & 9 & 32 & 174 & 71 & 42 & 14 & 64 & 679 \\
\hline Maine & 38 & 1 & 1 & 147 & 18 & 2 & 7 & 53 & 29 & 15 & 7 & 15 & 331 \\
\hline Maryland & 477 & 1 & 0 & 1,166 & 64 & 37 & 31 & 288 & 150 & 115 & 39 & 72 & 2,440 \\
\hline Massachusetts & 122 & 0 & 0 & 1,062 & 163 & 49 & 21 & 279 & 194 & 155 & 46 & 68 & 2,159 \\
\hline Michigan & 479 & 85 & 2 & 1,060 & 161 & 43 & 77 & 485 & 244 & 155 & 38 & 164 & 2,991 \\
\hline Minnesota & 154 & 84 & 1 & 576 & 40 & 26 & 145 & 464 & 152 & 112 & 26 & 85 & 1,864 \\
\hline Mississippi & 52 & 68 & 2 & 106 & 16 & 10 & 28 & 158 & 38 & 24 & 7 & 41 & 548 \\
\hline Missouri & 77 & 57 & 3 & 450 & 20 & 22 & 71 & 430 & 138 & 89 & 22 & 118 & 1,495 \\
\hline Montana & 31 & 0 & 0 & 39 & 4 & 2 & 21 & 78 & 18 & 11 & 3 & 12 & 219 \\
\hline Nebraska & 18 & 13 & 6 & 129 & 12 & 3 & 84 & 248 & 39 & 20 & 7 & 23 & 596 \\
\hline Nevada & 13 & 1 & 1 & 610 & 23 & 6 & 13 & 73 & 44 & 20 & 11 & 32 & 844 \\
\hline New Hampshire & 61 & 2 & 2 & 195 & 13 & 5 & 8 & 79 & 45 & 27 & 8 & 22 & 465 \\
\hline New Jersey & 430 & 6 & 1 & 1,354 & 105 & 133 & 36 & 297 & 218 & 150 & 58 & 87 & 2,875 \\
\hline New Mexico & 72 & 0 & 0 & 121 & 17 & 2 & 8 & 53 & 34 & 14 & 6 & 27 & 353 \\
\hline New York & 374 & 64 & 2 & 1,219 & 144 & 105 & 67 & 621 & 354 & 298 & 89 & 177 & 3,511 \\
\hline North Carolina & 1,347 & 40 & 5 & 1,173 & 88 & 27 & 101 & 382 & 201 & 87 & 31 & 106 & 3,583 \\
\hline North Dakota & 8 & 1 & 0 & 20 & 1 & 1 & 61 & 69 & 14 & 6 & 2 & 7 & 189 \\
\hline Ohio & 436 & 171 & 3 & 1,479 & 77 & 101 & 163 & 524 & 226 & 159 & 46 & 150 & 3,532 \\
\hline Oklahoma & 241 & 6 & 1 & 199 & 13 & 12 & 31 & 159 & 54 & 38 & 9 & 56 & 819 \\
\hline Oregon & 1,043 & 5 & 1 & 406 & 42 & 19 & 38 & 265 & 74 & 36 & 18 & 66 & 2,010 \\
\hline Pennsylvania & 904 & 20 & 3 & 1,300 & 130 & 50 & 65 & 531 & 260 & 195 & 63 & 154 & 3,672 \\
\hline Rhode Island & 41 & 0 & 0 & 151 & 5 & 6 & 2 & 12 & 19 & 14 & 5 & 8 & 262 \\
\hline South Carolina & 394 & 353 & 1 & 606 & 32 & 21 & 19 & 143 & 78 & 33 & 14 & 50 & 1,745 \\
\hline South Dakota & 12 & 2 & 1 & 25 & 3 & 6 & 32 & 114 & 15 & 7 & 3 & 9 & 228 \\
\hline Tennessee & 301 & 387 & 5 & 603 & 46 & 17 & 51 & 335 & 127 & 73 & 20 & 91 & 2,050 \\
\hline Texas & 1,340 & 20 & 18 & 2,086 & 264 & 111 & 181 & 962 & 449 & 247 & 94 & 332 & 6,088 \\
\hline Utah & 128 & 2 & 1 & 195 & 10 & 6 & 18 & 111 & 60 & 21 & 10 & 37 & 600 \\
\hline Vermont & 24 & 1 & 0 & 72 & 6 & 2 & 7 & 49 & 17 & 10 & 4 & 4 & 196 \\
\hline Virginia & 248 & 60 & 1 & 1,170 & 80 & 20 & 48 & 427 & 161 & 130 & 35 & 115 & 2,493 \\
\hline Washington & 480 & 2 & 1 & 734 & 61 & 41 & 52 & 397 & 128 & 61 & 33 & 92 & 2,080 \\
\hline West Virginia & 13 & 0 & 0 & 92 & 4 & 3 & 4 & 39 & 24 & 17 & 4 & 20 & 220 \\
\hline Wisconsin & 238 & 492 & 3 & 633 & 64 & 17 & 102 & 478 & 136 & 66 & 20 & 70 & 2,317 \\
\hline Wyoming & 4 & 0 & 0 & 40 & 4 & 1 & 9 & 25 & 8 & 9 & 2 & 6 & 109 \\
\hline Total All States & 18,076 & 2,720 & 110 & 35,564 & 3,449 & 1,907 & 2,737 & 14,806 & 6,491 & 3,977 & 1,385 & 3,973 & 95,084 \\
\hline
\end{tabular}

* Values expressed in 2004 dollars (GDP Implicit Price Deflator, US Dept. Commerce). 


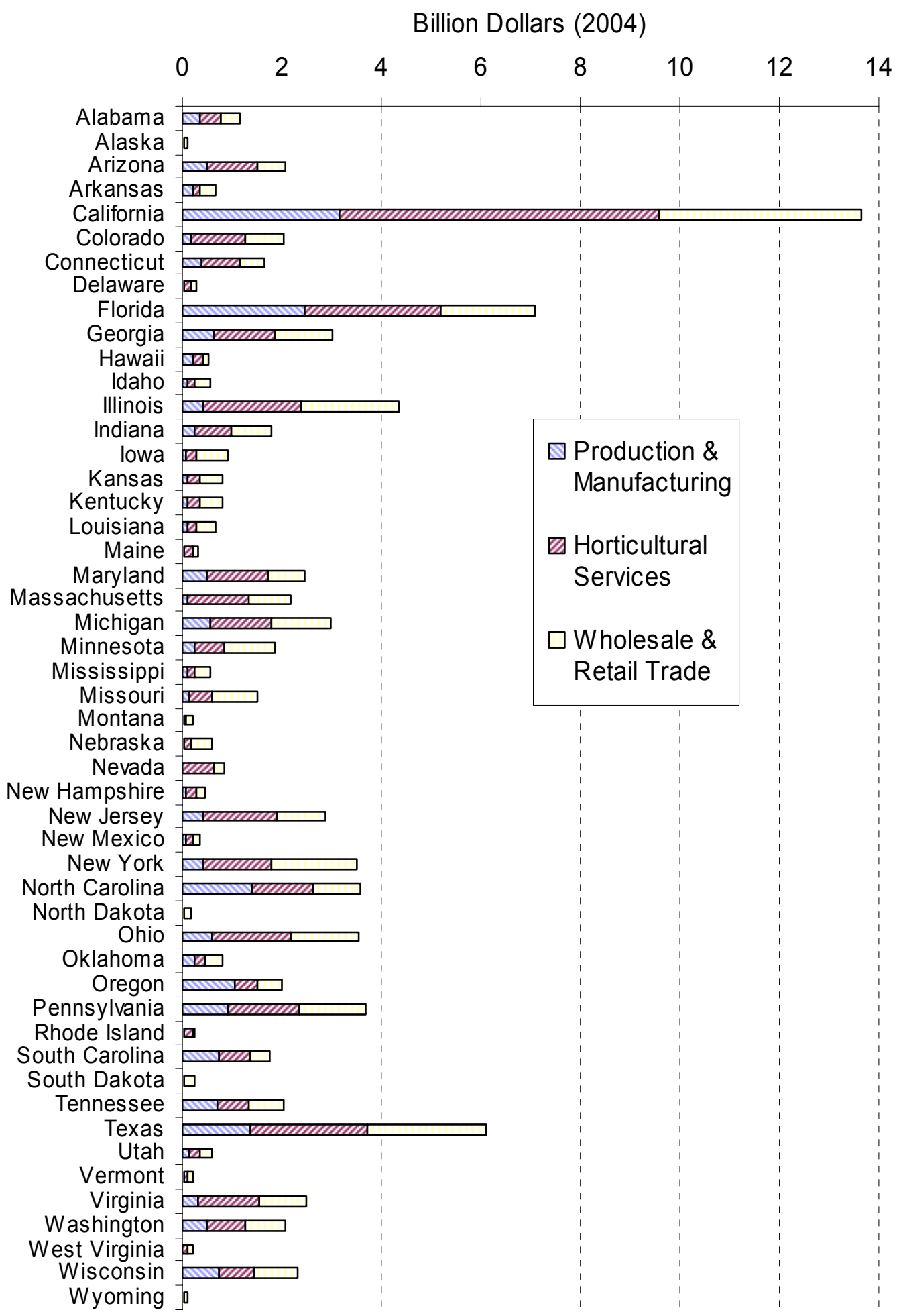

Figure 3-6. Value Added Impacts of the U.S. Green Industry by State and Industry Group, 2002 


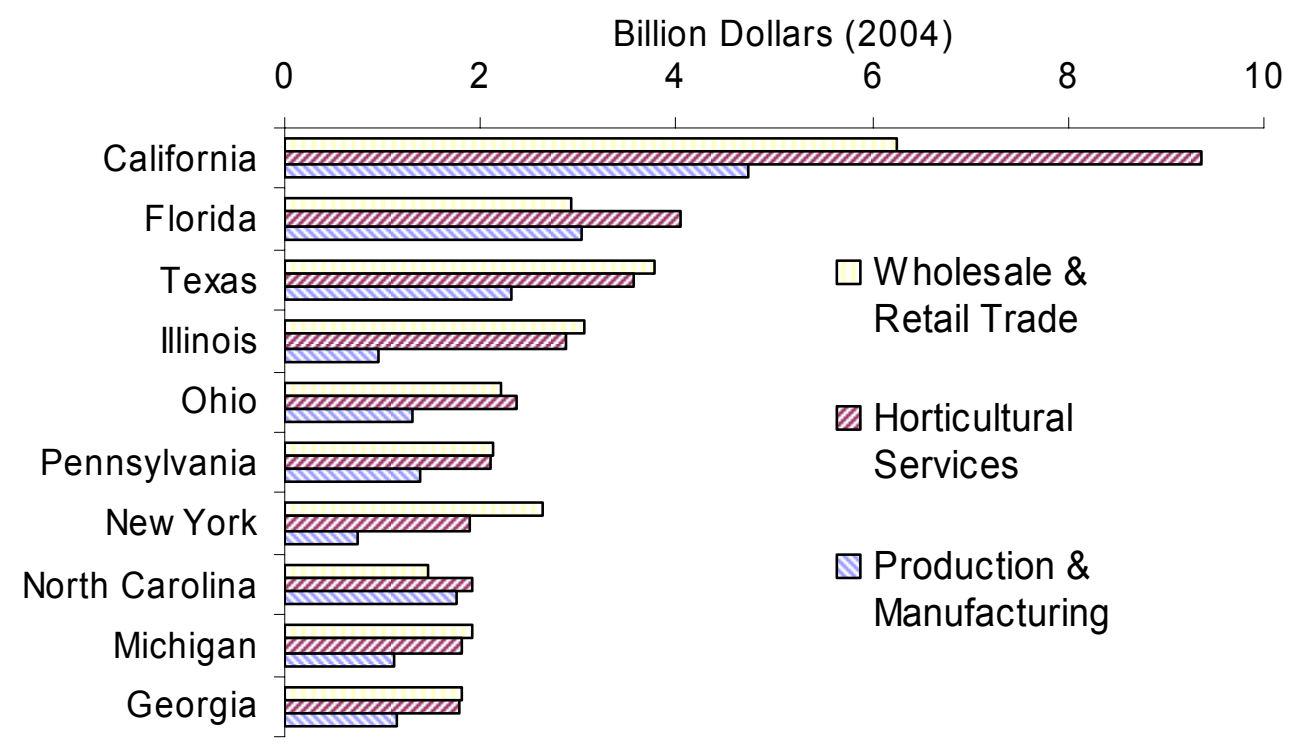

Figure 3-7. Output Impacts of the U.S. Green Industry in Leading States, 2002

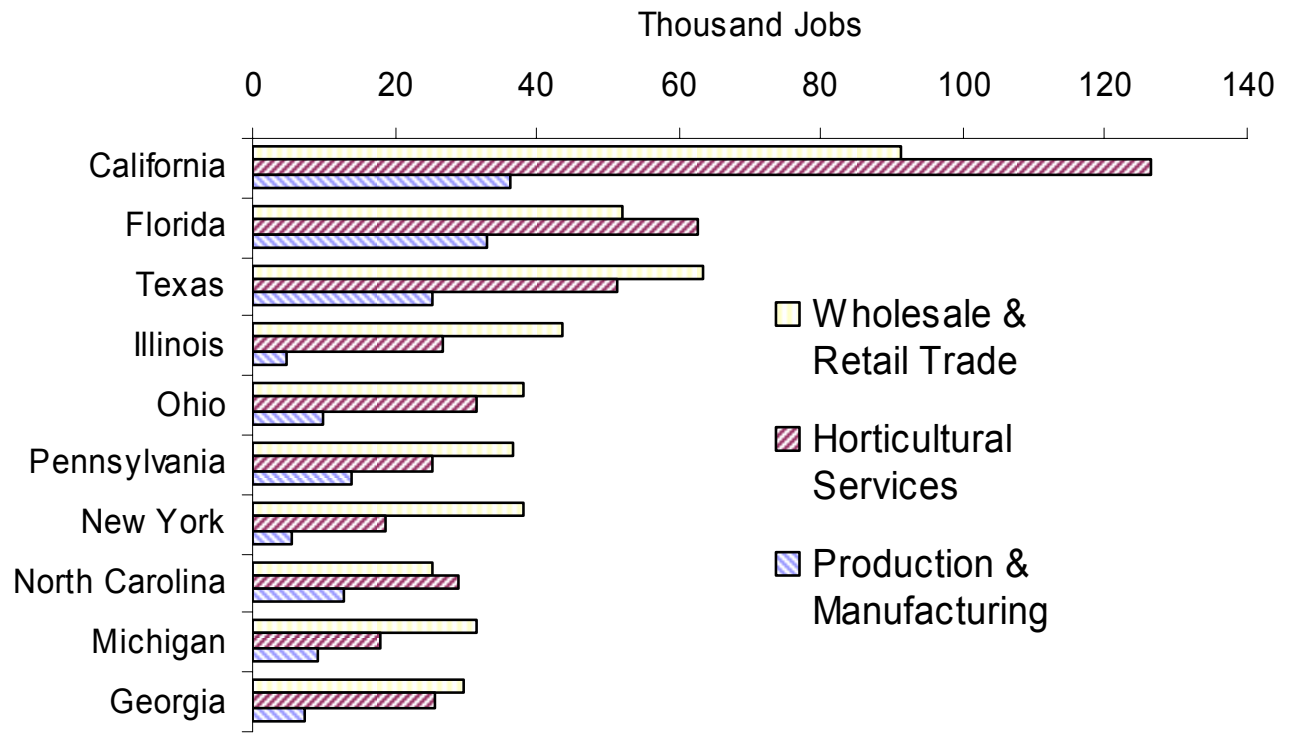

Figure 3-8. Employment Impacts of the U.S. Green Industry in Leading States, 2002 


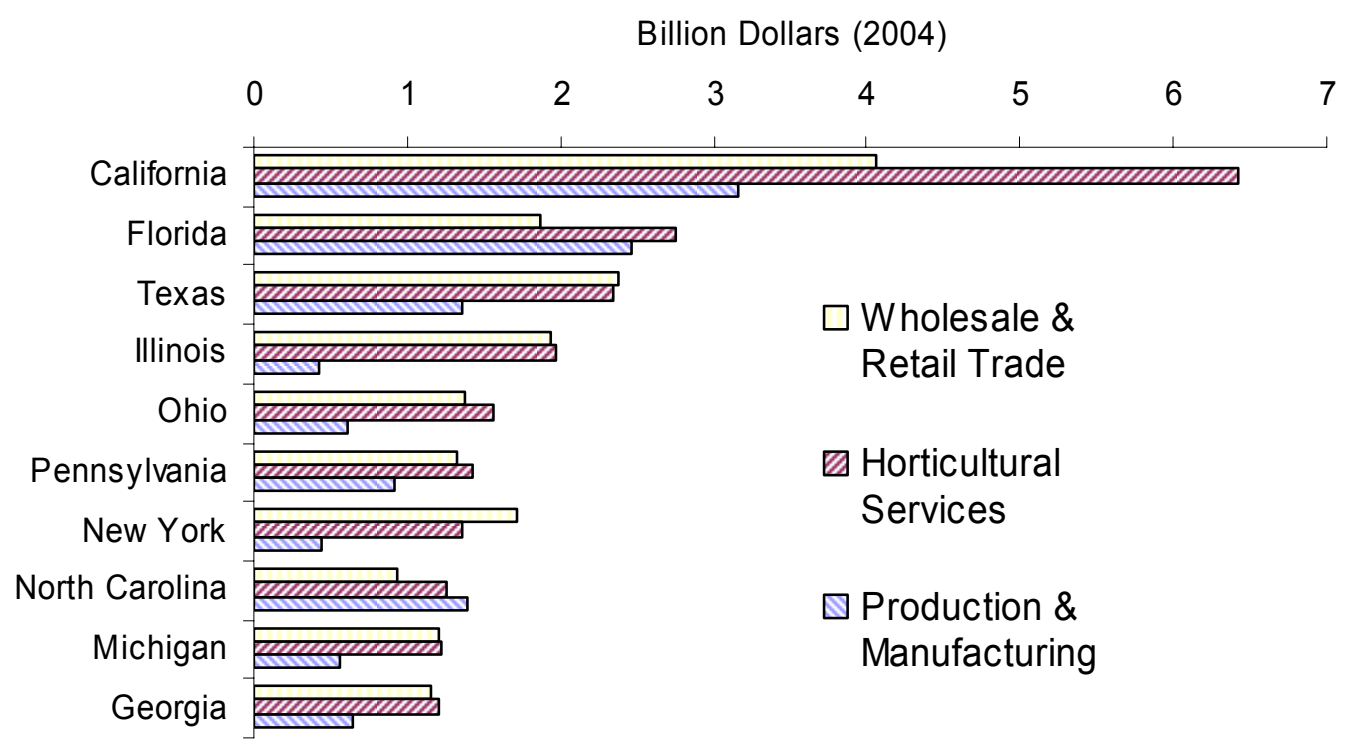

Figure 3-9. Value Added Impacts of the U.S. Green Industry in Leading States, 2002

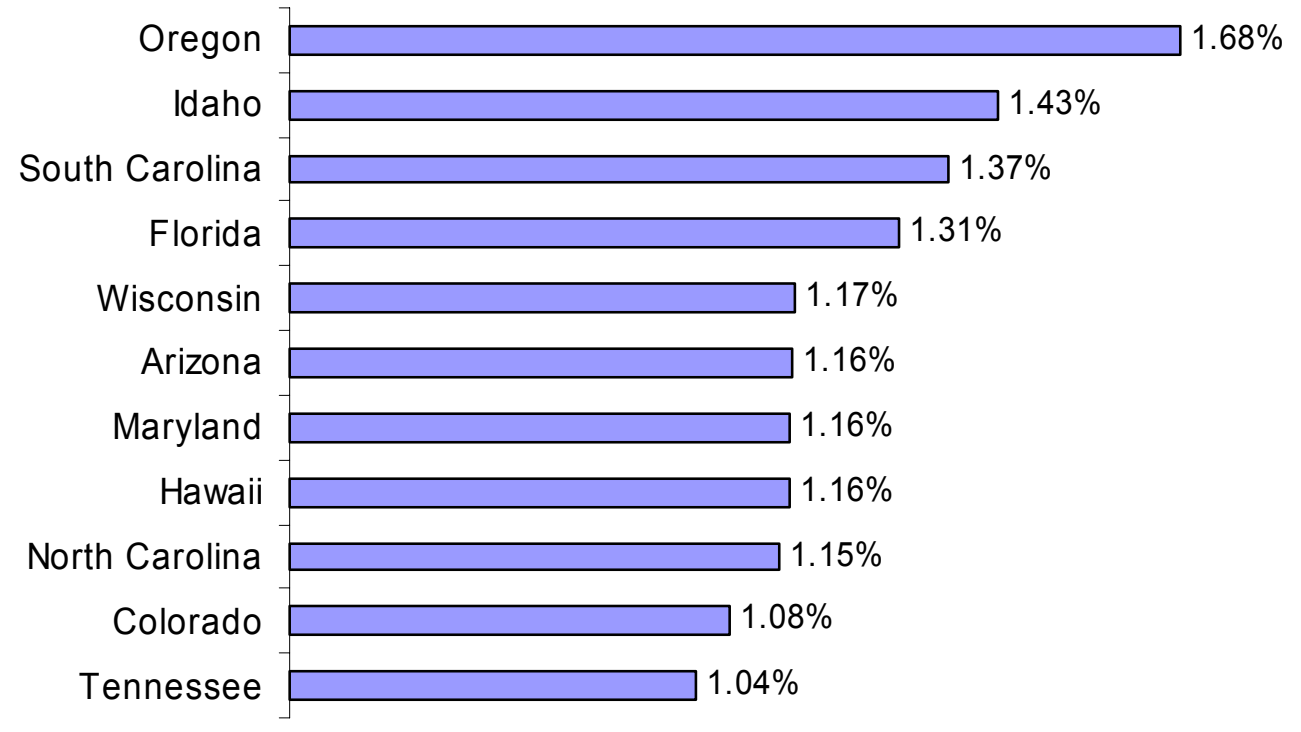

Figure 3-10. Rank Order of States by Green Industry Share of Gross State Product, 2002 
Table 3-6. Green Industry Share of Gross State Product, 2002

\begin{tabular}{|c|c|c|c|}
\hline State & $\begin{array}{l}\text { Total Value Added } \\
\text { Impact of Green } \\
\text { Industry (Mn\$)* }\end{array}$ & $\begin{array}{c}\text { Gross State } \\
\text { Product }(\mathrm{Mn} \$)^{*}\end{array}$ & $\begin{array}{c}\text { Green Industry } \\
\text { Share of GSP }\end{array}$ \\
\hline Alabama & 1,148 & 130,678 & $0.878 \%$ \\
\hline Alaska & 104 & 30,917 & $0.336 \%$ \\
\hline Arizona & 2,081 & 178,773 & $1.164 \%$ \\
\hline Arkansas & 676 & 74,857 & $0.902 \%$ \\
\hline California & 13,656 & $1,423,454$ & $0.959 \%$ \\
\hline Colorado & 2,019 & 186,712 & $1.081 \%$ \\
\hline Connecticut & 1,659 & 172,490 & $0.962 \%$ \\
\hline Delaware & 297 & 49,069 & $0.606 \%$ \\
\hline Florida & 7,076 & 541,684 & $1.306 \%$ \\
\hline Georgia & 3,020 & 318,276 & $0.949 \%$ \\
\hline Hawaii & 531 & 45,789 & $1.160 \%$ \\
\hline Idaho & 576 & 40,127 & $1.434 \%$ \\
\hline Illinois & 4,335 & 505,925 & $0.857 \%$ \\
\hline Indiana & 1,804 & 213,287 & $0.846 \%$ \\
\hline Iowa & 906 & 102,230 & $0.886 \%$ \\
\hline Kansas & 813 & 93,151 & $0.873 \%$ \\
\hline Kentucky & 821 & 127,259 & $0.645 \%$ \\
\hline Louisiana & 679 & 136,940 & $0.496 \%$ \\
\hline Maine & 331 & 40,628 & $0.815 \%$ \\
\hline Maryland & 2,440 & 210,096 & $1.161 \%$ \\
\hline Massachusetts & 2,159 & 299,813 & $0.720 \%$ \\
\hline Michigan & 2,991 & 365,584 & $0.818 \%$ \\
\hline Minnesota & 1,864 & 208,204 & $0.895 \%$ \\
\hline Mississippi & 548 & 71,950 & $0.761 \%$ \\
\hline Missouri & 1,495 & 195,176 & $0.766 \%$ \\
\hline Montana & 219 & 24,741 & $0.886 \%$ \\
\hline Nebraska & 596 & 63,443 & $0.940 \%$ \\
\hline Nevada & 844 & 84,486 & $0.999 \%$ \\
\hline New Hampshire & 465 & 48,338 & $0.962 \%$ \\
\hline New Jersey & 2,875 & 395,642 & $0.727 \%$ \\
\hline New Mexico & 353 & 55,693 & $0.635 \%$ \\
\hline New York & 3,511 & 824,295 & $0.426 \%$ \\
\hline North Carolina & 3,583 & 312,435 & $1.147 \%$ \\
\hline North Dakota & 189 & 20,585 & $0.920 \%$ \\
\hline Ohio & 3,532 & 404,025 & $0.874 \%$ \\
\hline Oklahoma & 819 & 98,998 & $0.827 \%$ \\
\hline Oregon & 2,010 & 119,824 & $1.678 \%$ \\
\hline Pennsylvania & 3,672 & 446,408 & $0.823 \%$ \\
\hline Rhode Island & 262 & 38,493 & $0.682 \%$ \\
\hline South Carolina & 1,745 & 127,334 & $1.370 \%$ \\
\hline South Dakota & 228 & 26,0201 & $0.877 \%$ \\
\hline Tennessee & 2,050 & 197,860 & $1.036 \%$ \\
\hline Texas & 6,088 & 804,935 & $0.756 \%$ \\
\hline Utah & 600 & 75,944 & $0.790 \%$ \\
\hline Vermont & 196 & 20,402 & $0.961 \%$ \\
\hline Virginia & 2,493 & 299,294 & $0.833 \%$ \\
\hline Washington & 2,080 & 242,421 & $0.858 \%$ \\
\hline West Virginia & 220 & 47,371 & $0.464 \%$ \\
\hline Wisconsin & 2,317 & 198,410 & $1.168 \%$ \\
\hline Wyoming & 109 & 21,111 & $0.517 \%$ \\
\hline Total All States & 95,084 & $10,830,712$ & $0.878 \%$ \\
\hline
\end{tabular}

* Expressed in 2004 dollars using GDP Implicit Price Deflator.

Source for GSP: U.S. Dept. Commerce, Bureau of Economic Analysis 


\section{Results for Production and Manufacturing Sectors}

Production and manufacturing activity in the Green Industry includes the sectors for nursery and greenhouse, lawn and garden equipment manufacturers, and greenhouse manufacturers (prefabricated metal buildings). The activities included within each sector are indicated in Table 4-1.

Nursery, Greenhouse and Floriculture Production (NAICS 1114). This sector is comprised of establishments primarily engaged in growing nursery products, nursery stock, shrubbery, bulbs, fruit stock, sod, and so forth, under cover or in open fields and/or growing short rotation woody trees with a growth and harvest cycle of 10 years or less for pulp or tree stock. As a cross reference to other related industry sectors, establishments primarily engaged in growing vegetable and melon bedding plants are classified under Vegetable and Melon Farming (NAICS 11121); establishments primarily engaged in operating timber tracts (i.e., growing cycle greater than 10 years) are classified under Timber Tract Operations (113110); establishments primarily engaged in producing seedling trees for planting for commercial timber production are classified under Forest Nurseries and Gathering of Forest Products (113210); establishments primarily engaged in retailing nursery, tree stock, and floriculture products primarily purchased from others are classified under Nursery, Garden Center, and Farm Supply Stores (NAICS 444220).

Lawn and Garden Equipment Manufacturing (NAICS 333112). This sector is comprised of establishments primarily engaged in manufacturing of powered lawn mowers, lawn and garden tractors, and other home lawn and garden equipment such as tillers, shredders, and yard vacuums and blowers. As a cross reference to other related industry sectors, establishments primarily engaged in manufacturing commercial mowing and other turf and grounds care equipment are classified under Farm Machinery And Equipment Manufacturing (NAICS 333111); establishments primarily engaged in manufacturing non-powered lawn and garden shears, edgers, pruners, and lawnmowers are classified under Cutlery and Handtool Manufacturing (NAICS 33221).

Table 4-1. Products Included in the Production and Manufacturing Sectors of the Green Industry Industry Sector/Subsector (NAICS code) Products

\begin{tabular}{ll}
\hline & $\begin{array}{l}\text { Nursery and Tree } \\
\text { Nursery \& } \\
\text { Preenhouse } \\
(1114)\end{array}$ \\
& $\begin{array}{l}\text { Floduction (111421) } \\
(111422)\end{array}$
\end{tabular}

Lawn \& garden tractor and home lawn and garden equipment manufacturing (333112)

Greenhouse manufacturing (Prefab. metal building and component manufacturing, 332311)

\begin{abstract}
Nursery products, nursery stock, shrubbery, bulbs, fruit stock, sod grown under cover or in open fields, short rotation woody trees with a growing and harvesting cycle of ten years or less.
\end{abstract}

Cut flowers, roses, cut cultivated greens, potted flowering plants, foliage plants, and flower seeds grown under cover and in open fields.

Manufacturing of powered lawn mowers, lawn and garden tractors, and other home lawn and garden equipment such as tillers, shredder and yard vacuums and blowers.

Manufacturing prefabricated metal buildings, panels and sections.

The number of establishments, employment, payroll, and sales receipts for the production and manufacturing sectors of the Green Industry in 2002 are shown in Table 4-2. There were a total of 56,233 business establishments involved in these sectors of the industry, mostly as nursery and greenhouse producers, with a relatively small number of lawn and garden equipment and greenhouse manufacturing firms (145 and 18, respectively). Total sales receipts in 2002 were $\$ 23.0$ billion (Bn), including \$16.4 Bn for nurseries, $\$ 6.5 \mathrm{Bn}$ for lawn \& garden equipment manufacturers, and \$121 Mn for greenhouse manufacturers. The production and manufacturing sectors represented about 16 percent of the overall Green Industry sales receipts. Nursery and greenhouse firms are typically rather small, with average annual sales of $\$ 291,800$, compared to average sales of \$44.9 Mn for lawn and garden equipment manufacturers and \$5.7 Mn for greenhouse manufacturers. For lawn and garden equipment manufacturers, total reported employment was 22,201 employees and total payroll was $\$ 681$ million (Mn). Employment and payroll for greenhouse manufacturers were estimated in proportion to the 
sales of greenhouses within the larger industry group of Prefabricated Building Manufacturers. Employment for the nursery and greenhouse sector totaled 150,543 employees, with an annual payroll amounting to $\$ 4.5 \mathrm{Bn}$.

Table 4-2. Establishments, Employment, Payroll and Sales in Production and Manufacturing Sectors of the U.S. Green Industry, 2002

\begin{tabular}{lrrrr} 
Industry Sector & $\begin{array}{c}\text { Establish- } \\
\text { ments }\end{array}$ & $\begin{array}{c}\text { Paid } \\
\text { Employees }\end{array}$ & $\begin{array}{c}\text { Annual } \\
\text { Payroll } \\
(\$ M n)\end{array}$ & $\begin{array}{c}\text { Sales } \\
\text { Receipts } \\
(\$ M n)\end{array}$ \\
\hline Nursery \& Greenhouse & 56,070 & 150,543 & 4,459 & 16,362 \\
Lawn \& Garden Equipment Manufacturing & 145 & 22,201 & 681 & 6,517 \\
Greenhouse Manufacturing* & 18 & 659 & 21,756 & 121 \\
Total Production/Manufacturing & 56,233 & 173,043 & 26,839 & 23,000 \\
\hline
\end{tabular}

* Payroll and employment estimated proportional to merchandise or product line sales as share of total sales.

Sources: 2002 Economic Census (US Census Bureau), and 2002 Census of Agriculture (USDA).

Economic impact estimates for the production and manufacturing sectors are summarized in Table 4-3. Total impacts for this industry group included output of $\$ 34.6$ billion $(\mathrm{Bn})$, employment impacts of 300,677 jobs, value added of $\$ 20.8 \mathrm{Bn}$, labor income of $\$ 11.0 \mathrm{Bn}$, and indirect business taxes of $\$ 784 \mathrm{Mn}$. The nursery and greenhouse sector was the largest in this group by all measures, with $\$ 26.1 \mathrm{Bn}$ in output impacts, 261,408 jobs, $\$ 18.1 \mathrm{Bn}$ in value added, $\$ 9.6 \mathrm{Bn}$ in labor income, and $\$ 647 \mathrm{Mn}$ in indirect business taxes. The lawn and garden equipment manufacturing sector had total impacts of $\$ 8.3 \mathrm{Bn}$ in output, 37,343 jobs, $\$ 2.6 \mathrm{Bn}$ in value added, $\$ 1.3$ $\mathrm{Bn}$ in labor income, and $\$ 129 \mathrm{Mn}$ in indirect business taxes. Greenhouse manufacturing had total output impacts of \$244 Mn, employment impacts of 1,927 jobs, value added impacts of \$110 Mn, labor income impacts of \$78 $\mathrm{Mn}$, and indirect business tax impacts of $\$ 7 \mathrm{Mn}$. Collectively, the production and manufacturing sectors represented 23 percent of overall Green Industry output impacts, 15 percent of employment impacts, and 22 percent of value added impacts.

\section{Table 4-3. Economic Impacts of the Production and Manufacturing Sectors of the U.S. Green} Industry, 2002

\begin{tabular}{lrrrrr}
\multicolumn{1}{c}{ Industry Sector } & $\begin{array}{c}\text { Output } \\
(\$ \mathrm{Mn})^{*}\end{array}$ & $\begin{array}{c}\text { Employ- } \\
\text { ment } \\
(\mathrm{jobs})\end{array}$ & $\begin{array}{c}\text { Value } \\
\text { Added } \\
(\$ \mathrm{Mn})^{*}\end{array}$ & $\begin{array}{c}\text { Labor } \\
\text { Income } \\
(\$ \mathrm{Mn})^{*}\end{array}$ & $\begin{array}{c}\text { Indirect } \\
\text { Business } \\
\text { Taxes } \\
(\$ \mathrm{Mn})^{*}\end{array}$ \\
\hline Nursery \& Greenhouse & 26,053 & 261,408 & 18,076 & 9,612 & 647 \\
Lawn \& Garden Equipment Manufacturing. & 8,281 & 37,343 & 2,610 & 1,346 & 129 \\
Greenhouse Manufacturing & 244 & 1,927 & 110 & 78 & 7 \\
Total Production \& Manufacturing & 34,578 & 300,677 & 20,796 & 11,037 & 784 \\
\hline
\end{tabular}

* Values expressed in 2004 dollars (GDP Implicit Price Deflator, US Dept. Commerce)

\section{Nursery and Greenhouse Sector}

Total economic impacts and other characteristics of the nursery and greenhouse industry sector are summarized by state in Table 4-4. For the nursery and greenhouse sector, the top five individual states in terms of output impacts were California $(\$ 4.47 \mathrm{Bn})$, Florida $(\$ 3.01 \mathrm{Bn})$, Texas $(\$ 2.28 \mathrm{Bn})$, Oregon $(\$ 1.69 \mathrm{Bn})$, and North Carolina ( $\$ 1.64 \mathrm{Bn})$. Collectively, these top five states accounted for 30 percent of farms, 50 percent of industry output impacts, 49 percent of employment impacts, and 51 percent of value added impacts. The second tier of states with large output impacts included Pennsylvania (\$1.32 Bn), Michigan (\$910 Mn), Ohio (\$756 Mn), Washington $(\$ 630 \mathrm{Mn})$, and Maryland $(\$ 602 \mathrm{Mn})$. Combined, these top 10 states represented 66 percent of total industry output impacts, while the top 20 states represented 86 percent. The two top states of California and Florida both had over 4,000 nursery and greenhouse farms, while Oregon and Pennsylvania had over 3,000 farms, and Texas, North Carolina, Michigan, Ohio, Tennessee and New York all had over 2,000 farms. The states of California and Florida had value added impacts of \$3.08 Bn and \$2.46 Bn, respectively. The employment impacts 
represented an average of 15.4 jobs per million dollars output by the nursery and greenhouse sector, and the value added impacts amounted to 69 percent of total output impacts. Total economic impacts are influenced by the proportion of output sold outside the region ("export share"), which varied from a high of 93 percent for Hawaii to less than 5 percent for Colorado.

\section{Lawn and Garden Equipment and Greenhouse Manufacturing Sectors}

Total economic impacts of the lawn and garden equipment manufacturing industry sector are summarized by state in Table 4-5. For the this sector, the top five individual states in terms of output impacts were Wisconsin ( $\$ 1.27$ $\mathrm{Bn})$, South Carolina ( $\$ 1.20 \mathrm{Bn})$, Tennessee ( $\$ 1.18 \mathrm{Bn})$, Georgia ( $\$ 565 \mathrm{Mn})$ and Arkansas ( $\$ 549 \mathrm{Mn})$. These top five states accounted for 19 percent of industry firms, 58 percent of output impacts, 61 percent of employment impacts, and 59 percent of value added impacts. The second tier of states with large output impacts included Ohio (\$539 Mn), Illinois ( $\$ 511 \mathrm{Mn}$ ), Minnesota (\$245 Mn), California (\$244 Mn) and Indiana (\$238 Mn). These top 10 states represented 79 percent of total industry output impacts, while the top 20 states represented 98 percent. These results indicate that this sector is more concentrated than the nursery and greenhouse sector. The top three states of Wisconsin, South Carolina and Tennessee each had employment impacts in excess of 5,000 jobs from this industry, and value added impacts exceeding $\$ 300 \mathrm{Mn}$. The employment impacts represented an average of 5.5 jobs per million dollars output by this sector, and the value added impacts amounted to 32 percent of total output impacts. The share of output exported from the state varied from a high of 57 percent (Iowa) to less than 10 percent for more than half of the states estimated.

Total economic impacts of the greenhouse manufacturing industry sector are summarized by state in Table 4-6. For the this sector, the top five individual states in terms of output impacts were Texas $(\$ 38 \mathrm{Mn})$, California ( $\$ 21$ $\mathrm{Mn})$, Nebraska ( $\$ 15 \mathrm{Mn})$, Illinois ( $\$ 15 \mathrm{Mn}$ ) and Georgia (\$12 Mn). These top five states accounted for 29 percent of industry firms, 42 percent of output impacts, 40 percent of employment impacts, and 43 percent of value added impacts. A second tier of states with large output impacts included North Carlina ( $\$ 12 \mathrm{Mn})$, Tennessee $(\$ 10 \mathrm{Mn})$, Florida ( $\$ 10 \mathrm{Mn})$, Alabama ( $\$ 9 \mathrm{Mn}$ ) and Indiana ( $\$ 8 \mathrm{Mn})$. These top 10 states represented 62 percent of total industry output impacts, while the top 20 states represented 84 percent. The top two states of Texas and California each had employment impacts in excess of 150 jobs from this industry, and value added impacts exceeding $\$ 10$ Mn. The employment impacts represented an average of 15.3 jobs per million dollars output by this sector, and the value added impacts amounted to 45 percent of total output impacts. The share of output exported from the state was typically over 90 percent, and one states exported all (100\%) of production. 
Table 4-4. Economic Impacts of the U.S. Nursery and Greenhouse Sector by State, 2002

\begin{tabular}{|c|c|c|c|c|c|c|c|c|}
\hline State & $\begin{array}{c}\text { Number } \\
\text { Farms }\end{array}$ & $\begin{array}{l}\text { Output } \\
\text { (\$Mn) }\end{array}$ & $\begin{array}{l}\text { Output } \\
\text { Impacts } \\
(\$ M n)^{*}\end{array}$ & $\begin{array}{l}\text { Employ- } \\
\text { ment } \\
\text { Impacts } \\
\text { (jobs) }\end{array}$ & $\begin{array}{l}\text { Value } \\
\text { Added } \\
\text { Impacts } \\
(\$ M n)^{*}\end{array}$ & $\begin{array}{l}\text { Labor } \\
\text { Income } \\
\text { Impacts } \\
(\$ M n)^{*}\end{array}$ & $\begin{array}{c}\text { Indirect } \\
\text { Business Tax } \\
\text { Impacts } \\
(\$ M n)^{*}\end{array}$ & $\begin{array}{l}\text { Export } \\
\text { Share }\end{array}$ \\
\hline California & 4,423 & $3,286.6$ & $4,470.3$ & 35,268 & $3,079.0$ & $1,733.1$ & 87.7 & $20.7 \%$ \\
\hline Florida & 4,718 & $1,844.1$ & $3,006.2$ & 32,821 & $2,456.3$ & $1,230.3$ & 86.3 & $41.3 \%$ \\
\hline Texas & 2,137 & $1,381.4$ & $2,275.6$ & 25,038 & $1,340.0$ & 771.0 & 57.4 & $39.1 \%$ \\
\hline Oregon & 3,039 & 806.9 & $1,692.6$ & 21,554 & $1,042.6$ & 700.7 & 49.4 & $77.7 \%$ \\
\hline North Carolina & 2,587 & 937.4 & $1,637.9$ & 12,478 & $1,346.7$ & 574.5 & 50.9 & $62.0 \%$ \\
\hline Pennsylvania & 3,073 & 732.7 & $1,321.3$ & 13,562 & 904.1 & 541.3 & 36.5 & $56.7 \%$ \\
\hline Michigan & 2,185 & 628.7 & 910.1 & 8,526 & 479.4 & 15.6 & 16.3 & $34.3 \%$ \\
\hline Ohio & 2,678 & 562.7 & 755.9 & 7,676 & 435.7 & 236.0 & 12.1 & $28.6 \%$ \\
\hline Washington & 1,883 & 391.9 & 629.9 & 6,616 & 480.1 & 304.1 & 14.9 & $46.9 \%$ \\
\hline Maryland & 769 & 318.0 & 601.5 & 5,650 & 477.1 & 255.2 & 17.3 & $58.7 \%$ \\
\hline Arizona & 367 & 284.5 & 595.7 & 4,781 & 434.7 & 255.3 & 18.6 & $83.5 \%$ \\
\hline Georgia & 1,199 & 315.3 & 566.8 & 4,690 & 467.6 & 206.7 & 18.4 & $57.8 \%$ \\
\hline New Jersey & 1,828 & 356.9 & 562.0 & 6,968 & 430.3 & 231.2 & 14.9 & $51.5 \%$ \\
\hline Tennessee & 2,323 & 282.8 & 548.0 & 10,757 & 301.1 & 175.5 & 14.7 & $66.9 \%$ \\
\hline New York & 2,552 & 344.3 & 533.9 & 4,525 & 373.8 & 218.6 & 13.7 & $50.0 \%$ \\
\hline Connecticut & 685 & 245.8 & 452.7 & 4,796 & 374.7 & 208.1 & 13.9 & $76.1 \%$ \\
\hline South Carolina & 771 & 321.7 & 445.2 & 4,882 & 394.3 & 118.7 & 11.5 & $33.5 \%$ \\
\hline Illinois & 1,108 & 357.5 & 431.8 & 2,555 & 268.2 & 138.8 & 6.7 & $11.6 \%$ \\
\hline Oklahoma & 578 & 222.6 & 428.9 & 5,405 & 240.9 & 142.7 & 11.5 & $66.7 \%$ \\
\hline Wisconsin & 1,487 & 234.5 & 423.8 & 3,774 & 238.2 & 150.2 & 10.7 & $67.6 \%$ \\
\hline Alabama & 797 & 251.5 & 411.0 & 4,384 & 344.8 & 142.1 & 12.1 & $58.4 \%$ \\
\hline Virginia & 1,241 & 218.7 & 372.6 & 4,956 & 248.0 & 143.3 & 9.4 & $52.5 \%$ \\
\hline Minnesota & 983 & 224.4 & 310.2 & 1,983 & 153.6 & 91.2 & 5.6 & $24.9 \%$ \\
\hline Colorado & 535 & 261.4 & 289.5 & 1,529 & 176.6 & 103.0 & 3.1 & $4.5 \%$ \\
\hline Indiana & 1,117 & 187.5 & 276.2 & 2,192 & 155.9 & 85.7 & 5.8 & $38.0 \%$ \\
\hline Hawaii & 1,386 & 110.3 & 254.4 & 3,394 & 200.1 & 132.8 & 7.7 & $93.4 \%$ \\
\hline Massachusetts & 902 & 153.5 & 198.9 & 3,406 & 122.0 & 82.6 & 3.1 & $20.3 \%$ \\
\hline Utah & 275 & 119.4 & 160.0 & 1,583 & 128.4 & 74.9 & 3.1 & $20.2 \%$ \\
\hline Louisiana & 665 & 87.8 & 149.3 & 1,712 & 97.5 & 55.9 & 3.8 & $59.6 \%$ \\
\hline Missouri & 932 & 101.3 & 142.1 & 1,639 & 76.7 & 44.2 & 2.7 & $27.7 \%$ \\
\hline Kentucky & 1,193 & 96.1 & 132.4 & 1,911 & 109.7 & 54.2 & 3.1 & $35.4 \%$ \\
\hline Kansas & 369 & 57.6 & 113.6 & 851 & 54.6 & 33.6 & 3.1 & $80.1 \%$ \\
\hline Idaho & 458 & 66.3 & 107.0 & 919 & 90.6 & 55.7 & 2.7 & $52.4 \%$ \\
\hline Iowa & 554 & 77.6 & 106.3 & 646 & 52.6 & 27.9 & 1.9 & $33.1 \%$ \\
\hline New Hampshire & 337 & 53.7 & 101.1 & 1,444 & 61.1 & 39.8 & 2.7 & $70.4 \%$ \\
\hline New Mexico & 223 & 60.3 & 86.7 & 656 & 71.6 & 42.3 & 1.9 & $35.5 \%$ \\
\hline Arkansas & 330 & 47.0 & 72.8 & 733 & 57.5 & 27.5 & 1.9 & $52.9 \%$ \\
\hline Rhode Island & 225 & 37.6 & 67.0 & 895 & 41.5 & 25.6 & 1.7 & $80.5 \%$ \\
\hline Montana & 318 & 33.8 & 56.8 & 491 & 31.2 & 19.2 & 1.3 & $69.0 \%$ \\
\hline Mississippi & 390 & 47.3 & 55.6 & 657 & 52.0 & 21.7 & 1.2 & $14.3 \%$ \\
\hline Delaware & 129 & 33.3 & 53.4 & 375 & 44.4 & 18.5 & 1.5 & $62.4 \%$ \\
\hline Maine & 769 & 37.3 & 51.7 & 642 & 38.2 & 22.4 & 1.0 & $32.7 \%$ \\
\hline Nebraska & 355 & 34.3 & 40.0 & 159 & 18.5 & 10.5 & 0.4 & $12.5 \%$ \\
\hline West Virginia & 371 & 26.8 & 39.7 & 1,087 & 12.7 & 8.5 & 0.6 & $45.8 \%$ \\
\hline Vermont & 418 & 22.8 & 33.8 & 310 & 24.0 & 14.4 & 0.7 & $43.0 \%$ \\
\hline South Dakota & 119 & 18.4 & 22.8 & 109 & 11.7 & 6.1 & 0.3 & $22.0 \%$ \\
\hline Alaska & 111 & 12.7 & 18.0 & 143 & 10.2 & 5.5 & 0.4 & $41.9 \%$ \\
\hline North Dakota & 78 & 11.0 & 17.8 & 119 & 7.8 & 4.7 & 0.4 & $71.7 \%$ \\
\hline Nevada & 50 & 10.1 & 14.5 & 110 & 12.8 & 8.2 & 0.3 & $32.5 \%$ \\
\hline Wyoming & 50 & 6.4 & 7.8 & 49 & 4.4 & 2.7 & 0.1 & $20.2 \%$ \\
\hline Total & 56,070 & $16,362.4$ & $26,052.9$ & 261,408 & $18,075.9$ & $9,612.4$ & 647.1 & \\
\hline
\end{tabular}

* Values expressed in 2004 dollars (GDP Implicit Price Deflator, US Dept. Commerce). 
Table 4-5. Economic Impacts of the U.S. Lawn \& Garden Equipment Manufacturing Sector by State, 2002

\begin{tabular}{|c|c|c|c|c|c|c|c|c|c|c|}
\hline State & $\begin{array}{l}\text { Establish } \\
\text {-ments }\end{array}$ & $\begin{array}{c}\text { Employ- } \\
\text { ment } \\
\text { (jobs) }\end{array}$ & $\begin{array}{c}\text { Annual } \\
\text { Wages } \\
(\$ 1000)^{*}\end{array}$ & $\begin{array}{l}\text { Output } \\
(\$ M n)^{*}\end{array}$ & $\begin{array}{l}\text { Output } \\
\text { Impacts } \\
(\$ M n)^{*}\end{array}$ & $\begin{array}{l}\text { Employ- } \\
\text { ment } \\
\text { Impacts } \\
\text { (jobs) }\end{array}$ & $\begin{array}{l}\text { Value } \\
\text { Added } \\
\text { Impacts } \\
(\$ M n)^{*}\end{array}$ & $\begin{array}{l}\text { Labor } \\
\text { Income } \\
\text { Impacts } \\
(\$ M n)^{*}\end{array}$ & $\begin{array}{c}\text { Indirect } \\
\text { Business } \\
\text { Tax } \\
\text { Impacts } \\
(\$ M n)^{*}\end{array}$ & $\begin{array}{l}\text { Export } \\
\text { Share }\end{array}$ \\
\hline Wisconsin & 8 & 3,157 & 101 & 964 & 1,274 & 6,308 & 490 & 258 & 24 & $29.7 \%$ \\
\hline South Carolina & 3 & 3,157 & 101 & 964 & 1,196 & 5,585 & 352 & 213 & 18 & $27.6 \%$ \\
\hline Tennessee & 8 & 3,033 & 95 & 908 & 1,183 & 5,768 & 383 & 203 & 21 & $27.8 \%$ \\
\hline Georgia & 7 & 1,473 & 47 & 450 & 565 & 2,573 & 171 & 91 & 10 & $22.1 \%$ \\
\hline Arkansas & 3 & 1,473 & 47 & 450 & 549 & 2,572 & 135 & 72 & 7 & $28.7 \%$ \\
\hline Ohio & 9 & 1,473 & 47 & 450 & 539 & 2,340 & 168 & 87 & 7 & $23.0 \%$ \\
\hline Illinois & 7 & 1,473 & 47 & 450 & 511 & 2,006 & 155 & 78 & 7 & $9.5 \%$ \\
\hline Minnesota & 6 & 631 & 20 & 193 & 245 & 1,151 & 83 & 44 & 5 & $24.6 \%$ \\
\hline California & 8 & 591 & 23 & 220 & 244 & 813 & 75 & 38 & 3 & $9.5 \%$ \\
\hline Indiana & 12 & 778 & 21 & 199 & 238 & 1,149 & 69 & 36 & 3 & $17.9 \%$ \\
\hline Mississippi & 3 & 631 & 20 & 193 & 235 & 1,090 & 66 & 34 & 3 & $26.8 \%$ \\
\hline Arizona & 3 & 631 & 20 & 193 & 225 & 974 & 69 & 35 & 3 & $18.1 \%$ \\
\hline Missouri & 4 & 631 & 20 & 193 & 215 & 851 & 55 & 28 & 2 & $9.5 \%$ \\
\hline New York & 3 & 631 & 20 & 193 & 212 & 788 & 61 & 30 & 3 & $9.5 \%$ \\
\hline Virginia & 1 & 631 & 20 & 193 & 210 & 803 & 59 & 29 & 2 & $9.5 \%$ \\
\hline Michigan & 6 & 534 & 20 & 188 & 206 & 707 & 83 & 3 & 3 & $9.5 \%$ \\
\hline Kansas & 5 & 316 & 10 & 96 & 116 & 531 & 38 & 18 & 2 & $23.4 \%$ \\
\hline North Carolina & 3 & 316 & 10 & 96 & 106 & 413 & 35 & 17 & 1 & $9.5 \%$ \\
\hline Pennsylvania & 10 & 147 & 5 & 45 & 50 & 195 & 17 & 8 & 1 & $9.5 \%$ \\
\hline Iowa & 1 & 51 & 2 & 15 & 23 & 135 & 8 & 4 & 0 & $56.8 \%$ \\
\hline Nebraska & 2 & 51 & 2 & 15 & 20 & 99 & 7 & 4 & 0 & $29.6 \%$ \\
\hline Alabama & 3 & 51 & 2 & 15 & 17 & 65 & 5 & 2 & 0 & $9.5 \%$ \\
\hline New Jersey & 3 & 51 & 2 & 15 & 17 & 62 & 5 & 3 & 0 & $9.5 \%$ \\
\hline Oklahoma & 1 & 51 & 2 & 15 & 17 & 67 & 5 & 2 & 0 & $9.5 \%$ \\
\hline Oregon & 1 & 51 & 2 & 15 & 17 & 65 & 4 & 2 & 0 & $9.5 \%$ \\
\hline Texas & 5 & 29 & 1 & 9 & 10 & 39 & 2 & 1 & 0 & $9.5 \%$ \\
\hline Florida & 5 & 52 & 1 & 8 & 9 & 60 & 2 & 1 & 0 & $9.5 \%$ \\
\hline Washington & 4 & 16 & 0 & 5 & 5 & 19 & 2 & 1 & 0 & $9.5 \%$ \\
\hline Total & 145 & 22,201 & 709 & 6,782 & 8,281 & 37,343 & 2,610 & 1,346 & 129 & \\
\hline
\end{tabular}

* Values expressed in 2004 dollars (GDP Implicit Price Deflator, US Dept. Commerce).

Results shown for states with at least 10 employees. 
Table 4.6. Economic Impacts of the U.S. Greenhouse Manufacturing Sector by State, 2002

\begin{tabular}{|c|c|c|c|c|c|c|c|c|c|}
\hline State & $\begin{array}{c}\text { Employ- } \\
\text { ment }\end{array}$ & $\begin{array}{c}\text { Annual } \\
\text { Wages } \\
(\$ 1000)^{*}\end{array}$ & $\begin{array}{l}\text { Output } \\
(\$ M n)^{*}\end{array}$ & $\begin{array}{l}\text { Output } \\
\text { Impacts } \\
(\$ M n)^{*}\end{array}$ & $\begin{array}{l}\text { Employ- } \\
\text { ment } \\
\text { Impacts } \\
\text { (jobs) }\end{array}$ & $\begin{array}{l}\text { Value } \\
\text { Added } \\
\text { Impacts } \\
(\$ M n)^{*}\end{array}$ & $\begin{array}{l}\text { Labor } \\
\text { Income } \\
\text { Impacts } \\
(\$ M n)^{*}\end{array}$ & $\begin{array}{c}\text { Indirect } \\
\text { Business } \\
\text { Tax } \\
\text { Impacts } \\
\text { (\$Mn)* }\end{array}$ & $\begin{array}{l}\text { Export } \\
\text { Share }\end{array}$ \\
\hline Texas & 89 & 3,291 & 18 & 38 & 283 & 18 & 13 & 1 & $95.1 \%$ \\
\hline California & 46 & 1,790 & 10 & 21 & 155 & 10 & 7 & 1 & $97.8 \%$ \\
\hline Illinois & 29 & 1,174 & 7 & 15 & 105 & 7 & 5 & 0 & $98.6 \%$ \\
\hline Nebraska & 43 & 1,479 & 8 & 15 & 128 & 6 & 5 & 0 & $96.3 \%$ \\
\hline Georgia & 39 & 1,059 & 6 & 12 & 99 & 5 & 4 & 0 & $96.5 \%$ \\
\hline North Carolina & 36 & 1,194 & 7 & 12 & 100 & 5 & 4 & 0 & $96.8 \%$ \\
\hline Florida & 29 & 888 & 5 & 10 & 84 & 5 & 3 & 0 & $98.3 \%$ \\
\hline Tennessee & 25 & 941 & 5 & 10 & 79 & 5 & 3 & 0 & $98.2 \%$ \\
\hline Alabama & 25 & 892 & 5 & 9 & 72 & 4 & 3 & 0 & $97.5 \%$ \\
\hline Indiana & 23 & 754 & 4 & 8 & 65 & 4 & 3 & 0 & $99.5 \%$ \\
\hline Ohio & 26 & 737 & 4 & 7 & 61 & 3 & 2 & 0 & $99.6 \%$ \\
\hline Arkansas & 16 & 576 & 3 & 6 & 44 & 2 & 2 & 0 & $97.0 \%$ \\
\hline Missouri & 15 & 548 & 3 & 6 & 49 & 3 & 2 & 0 & $97.5 \%$ \\
\hline Pennsylvania & 15 & 501 & 3 & 6 & 46 & 3 & 2 & 0 & $99.9 \%$ \\
\hline Wisconsin & 15 & 592 & 3 & 6 & 48 & 3 & 2 & 0 & $98.7 \%$ \\
\hline Arizona & 16 & 449 & 2 & 5 & 41 & 2 & 2 & 0 & $97.3 \%$ \\
\hline Iowa & 17 & 502 & 3 & 5 & 42 & 2 & 1 & 0 & $98.5 \%$ \\
\hline Louisiana & 15 & 478 & 3 & 5 & 39 & 2 & 1 & 0 & $96.4 \%$ \\
\hline Michigan & 12 & 467 & 3 & 5 & 36 & 2 & 0 & 0 & $100.0 \%$ \\
\hline Mississippi & 16 & 582 & 3 & 5 & 42 & 2 & 2 & 0 & $97.1 \%$ \\
\hline New York & 11 & 449 & 2 & 5 & 31 & 2 & 2 & 0 & $99.1 \%$ \\
\hline Oklahoma & 10 & 294 & 2 & 3 & 27 & 1 & 1 & 0 & $97.1 \%$ \\
\hline Total & 659 & 22,642 & 126 & 244 & 1,927 & 110 & 78 & 7 & \\
\hline
\end{tabular}

* Values expressed in 2004 dollars (GDP Implicit Price Deflator, US Dept. Commerce).

Results shown for states with at least 10 employees. 


\section{Results for the Horticultural Service Sectors}

Horticultural service firms include those that provide a plethora of lawn and landscape design, installation (construction), and maintenance services. This section also includes definitions for each major industry sector within the horticultural services industry. These include Landscape Services (561730) and Landscape Architectural Services (541320), which are described in more detail below (Table 5-1).

\section{Table 5-1. Specialties for Horticultural Service Firms.}

\section{Landscape Service Firms}

Arborist Services

Cemetery Plot Care Services

Fertilizing Lawns

Garden Maintenance Services

Hydroseeding Services (e.g., Decorative, Erosion

Control Purposes)

Landscape Care And Maintenance Services

Landscape Contractors (Except Construction)

Landscape Installation Services

Landscaping Services (Except Planning)

Lawn Care Services (e.g., Fertilizing, Mowing,

Seeding, Spraying)

Lawn Fertilizing Services

Lawn Maintenance Services

Lawn Mowing Services

Lawn Seeding Services

Lawn Spraying Services

Line Slash (i.e., Rights Of Way) Maintenance Services

Maintenance Of Plants And Shrubs In Buildings

Mowing Services (e.g., Highway, Lawn, Road Strip)

Ornamental Tree And Shrub Services

\section{Landscape Architectural Service Firms}

Architects' Offices, Landscape

Architects' Private Practices, Landscape

Architectural Services, Landscape

City Planning Services

Garden Planning Services

Golf Course Design Services

Industrial Land Use Planning Services

Land Use Design Services

Land Use Planning Services

Landscape Architects' Offices

Landscape Architects' Private Practices
Plant And Shrub Maintenance In Buildings

Plant Maintenance Services

Pruning Services, Ornamental Tree And Shrub

Seasonal Property Maintenance Services (I.E., Snow

Plowing)

Seeding Lawns

Shrub Services (e.g, Bracing, Planting, Pruning, Removal, Spraying)

Snow Plowing Services Combined With Landscaping

Services

Sod Laying Services

Spraying Lawns

Tree And Brush Trimming, Overhead Utility Line

Tree Pruning Services

Tree Removal Services

Tree Services (e.g., Bracing, Planting, Pruning,

Removal, Spraying)

Tree Surgery Services

Tree Trimming Services

Tropical Plant Maintenance Services

Turf (Except Artificial) Installation Services

Weed Control And Fertilizing Services (Except

Crop)

Landscape Architectural Services

Landscape Consulting Services

Landscape Design Services

Landscape Planning Services

Ski Area Design Services

Ski Area Planning Services

Town Planners' Offices

Town Planning Services

Urban Planners' Offices

Urban Planning Services

Landscaping Services (561730). This industry sector comprises: (1) establishments primarily engaged in providing landscape care and maintenance services and/or installing trees, shrubs, plants, lawns, or gardens and (2) establishments primarily engaged in providing these services along with the design of landscape plans and/or the construction (i.e., installation) of walkways, retaining walls, decks, fences, ponds, and similar structures. As a cross-reference, firms in this sector do not include establishments primarily engaged in: installing artificial turf or in constructing or installing walkways, retaining walls, decks, fences, ponds, or similar structures, which are 
classified in under Construction (Sector 23); planning and designing the development of land areas for projects, such as parks and other recreational areas; airports, highways, hospitals, schools, land subdivisions, and commercial, industrial, and residential areas (without also installing trees, shrubs, plants, lawns/gardens, walkways, retaining walls, decks, and similar items or structures), which are classified in, Landscape Architectural Services (541320); retailing landscaping materials and providing the installation and maintenance of these materials, which are classified under Nursery, Garden Center, and Farm Supply Stores (444220).

Landscape Architectural Services (541320). This industry sector is comprised of establishments primarily engaged in planning and designing the development of land areas for projects, such as parks and other recreational areas; airports; highways; hospitals; schools; land subdivisions; and commercial, industrial, and residential areas, by applying knowledge of land characteristics, location of buildings and structures, use of land areas, and design of landscape projects. Cross-references in the NAICS database do not include establishments primarily engaged in providing landscape care and maintenance services and/or installing trees, shrubs, plants, lawns, or gardens along with the design of landscape plans, which are classified under Landscaping Services (561730).

Sales, payroll, and employment data for the horticultural services sector are presented in Table 5-2. Within the total number of firms providing horticultural services (82,683), 93 percent are in the Landscape Services sector (76, 458 firms), with the remaining firms offering Landscape Architectural Services (6,225 firms). These sectors combined represent 32 percent of the total number of establishments included in the study. Although landscape service only represent roughly one-third of the number of establishments, they employ almost 51 percent of the total number of paid employees, with an annual payroll exceeding $\$ 11.5$ billion. Again, firms in the landscape service sector dominated the employment and payroll breakdown, representing 93 percent of the paid employees and 90 percent of the annual payroll. The $\$ 38.8 \mathrm{Bn}$ in sales for the landscape sector made up almost 27 percent of the total sales for all sectors included in the study $(\$ 145.4 \mathrm{Bn})$, with landscape services firms and landscape architectural firms representing 91 percent and 9 percent, respectively.

Table 5-2. Sales and Employment in the U.S. Horticultural Services Sectors, 2002

\begin{tabular}{|c|c|c|c|c|}
\hline Industry Sector & $\begin{array}{l}\text { Establish- } \\
\text { ments }\end{array}$ & $\begin{array}{c}\text { Paid } \\
\text { Employees }\end{array}$ & $\begin{array}{c}\text { Annual } \\
\text { Payroll } \\
\text { (\$Mn) }\end{array}$ & $\begin{array}{c}\text { Sales } \\
\text { Receipts } \\
(\$ M n)\end{array}$ \\
\hline Landscaping Services & 76,458 & 514,962 & 11,509 & 35,235 \\
\hline Landscape Architectural Services & 6,225 & 36,679 & 1,330 & 3,569 \\
\hline Total Horticultural Services & 82,683 & 551,641 & 12,839 & 38,804 \\
\hline
\end{tabular}

Sources: 2002 Economic Census (US Census Bureau)

Table 5-3 presents estimates of the economic impacts of the horticultural services sectors in the U.S. In terms of output, the landscaping services sector represents 92 percent of total horticultural services industry output, whereas landscape architecture firms represent the remaining 8 percent. Additionally, landscaping service firms accounted for 93 percent of the persons employed in the horticultural services industry at $\$ 11.5 \mathrm{Bn}$ in labor income. The horticultural services industry as a whole also paid $\$ 1.3 \mathrm{Bn}$ in indirect business taxes, roughly 20 percent of that paid by all sectors included in the survey. In terms of value added, the horticultural services sectors contributed $\$ 39 \mathrm{Bn}$, which was almost 41 percent of the total value added for all sectors in this study. 
Table 5-3. Economic Impacts of the U.S. Horticultural Services Sectors, 2002

\begin{tabular}{lrrrrr} 
Industry Sector & $\begin{array}{c}\text { Output } \\
\text { Impacts } \\
(\$ \mathrm{Mn})^{*}\end{array}$ & $\begin{array}{c}\text { Employ- } \\
\text { ment } \\
(\mathrm{jobs})\end{array}$ & $\begin{array}{c}\text { Value } \\
\text { Added } \\
(\mathbf{\$ M n})^{*}\end{array}$ & $\begin{array}{c}\text { Labor } \\
\text { Income } \\
(\mathbf{\$ M n})^{*}\end{array}$ & $\begin{array}{c}\text { Indirect } \\
\text { Business } \\
\text { Taxes } \\
(\$ \mathrm{Mn})^{*}\end{array}$ \\
\hline Landscaping Services & 52,971 & 704,875 & 35,564 & 27,719 & 1,312 \\
Landscape Architecture & 4,803 & 48,683 & 3,449 & 2,549 & 74 \\
Total Horticultural Services & 57,774 & 753,557 & 39,013 & 30,269 & 1,387 \\
\hline
\end{tabular}

* Values expressed in 2004 dollars (GDP Implicit Price Deflator, US Dept. Commerce).

\section{Landscape Services}

Tables 5-4 and 5-5 present the economic impacts of the landscape services and landscape architectural sectors by state, respectively. The top 5 states providing landscape services include (in rank order): California, Florida, Texas, Illinois, and Ohio with impacts ranging from \$8.3 Bn for California to $\$ 2.2 \mathrm{Bn}$ for Ohio. These top five states represent 38 percent of the national total, with combined impacts of a little over $\$ 20$ billion. The next five states in terms of importance are New Jersey, Pennsylvania, North Carolina, Virginia, and Maryland. The top 10 states combined represent 55 percent of the national economic impacts for landscape services, while the top 20 states account for 81 percent $(\$ 42.8 \mathrm{Bn})$ of the national total.

In terms of the 704,875 jobs created by the landscape services sector nationally, the top five employment states (California, Florida, Texas, Ohio, and North Carolina) account for 280,562 of them, representing 40 percent of the national work force. Illinois, Virginia, Georgia, Pennsylvania, and Arizona are the next five highest employing states, adding another 119,335 jobs and, when combined with the top five states, represent 57 percent of the national workforce. Considering these top 10 states, along with the next 10 states, then the top 20 employing states account for 80 percent of the national workforce.

\section{Landscape Architecture}

The top five states providing landscape architectural services include (in rank order): California, Texas, Illinois, Florida, and Michigan with impacts ranging from \$1.1 Bn for California to \$236 Mn for Michigan. These top five states represent 46 percent of the national total, with combined impacts of a little over $\$ 2.2$ billion. The next five states in terms of importance are Massachusetts, Colorado, New York, Pennsylvania, and New Jersey. The top 10 states combined represent two-thirds (66 percent) of the national economic impacts for landscape services, while the top 20 states account for 86 percent $(\$ 4.1 \mathrm{Bn})$ of the national total.

In terms of the 48,683 jobs created by the landscape services sector nationally, the top five employment states (California, Texas, Florida, Michigan, and Illinois) account for 21,904 of them, representing 45 percent of the national landscape architectural work force. Massachusetts, Pennsylvania, Colorado, New York, and North Carolina are the next 5 highest employing states, adding another 8,480 jobs and, when combined with the top five states, represent 62 percent of the national workforce. Considering these top 10 states, along with the next 10 states, then the top 20 employing states account for 84 percent of the national landscape architect workforce. 
Table 5-4. Economic Impacts of the U.S. Landscaping Services Sector by State, 2002

\begin{tabular}{|c|c|c|c|c|c|c|c|c|c|c|}
\hline Rank & State & $\begin{array}{l}\text { Establish- } \\
\text { ments }\end{array}$ & $\begin{array}{l}\text { Employ- } \\
\text { ment }\end{array}$ & $\begin{array}{l}\text { Annual } \\
\text { Wages } \\
(\$ M n)^{*}\end{array}$ & $\begin{array}{l}\text { Output } \\
\text { (\$Mn)* }\end{array}$ & $\begin{array}{l}\text { Output } \\
\text { Impacts } \\
(\$ M n)^{*}\end{array}$ & $\begin{array}{l}\text { Employ- } \\
\text { ment } \\
\text { Impacts } \\
\text { (jobs) }\end{array}$ & $\begin{array}{l}\text { Value } \\
\text { Added } \\
\text { Impacts } \\
(\$ M n)^{*}\end{array}$ & $\begin{array}{l}\text { Labor } \\
\text { Income } \\
\text { Impacts } \\
(\$ M n)^{*}\end{array}$ & $\begin{array}{c}\text { Indirect } \\
\text { Business } \\
\text { Tax } \\
\text { Impacts } \\
(\$ M n)^{*}\end{array}$ \\
\hline & Total & 76,458 & 514,962 & 11,978 & 36,670 & 52,971 & 704,875 & 35,564 & 27,719 & 1,312 \\
\hline 1 & California & 7,271 & 86,446 & 1,790 & 5,480 & 8,269 & 115,134 & 5,644 & 4,523 & 215 \\
\hline 2 & Florida & 6,308 & 45,096 & 843 & 2,580 & 3,801 & 59,935 & 2,562 & 2,045 & 98 \\
\hline 5 & Ohio & 3,431 & 22,854 & 537 & 1,644 & 2,248 & 30,400 & 1,479 & 1,200 & 48 \\
\hline 6 & New Jersey & 3,568 & 16,163 & 462 & 1,414 & 1,982 & 21,878 & 1,354 & 1,095 & 49 \\
\hline 7 & Pennsylvania & 3,488 & 18,960 & 490 & 1,501 & 1,909 & 23,589 & 1,300 & 1,067 & 41 \\
\hline 8 & North Carolina & 2,620 & 17,939 & 337 & 1,033 & 1,803 & 27,658 & 1,173 & 910 & 53 \\
\hline 9 & Virginia & 2,040 & 17,829 & 387 & 1,183 & 1,760 & 24,768 & 1,170 & 938 & 43 \\
\hline 10 & Maryland & 1,598 & 13,940 & 344 & 1,054 & 1,720 & 21,702 & 1,166 & 929 & 45 \\
\hline 15 & Colorado & 1,523 & 11,552 & 296 & 907 & 1,408 & 17,234 & 939 & 749 & 38 \\
\hline 16 & Arizona & 1,373 & 15,461 & 281 & 860 & 1,393 & 21,970 & 929 & 733 & 39 \\
\hline 17 & Indiana & 1,592 & 9,992 & 251 & 768 & 1,096 & 14,155 & 714 & 573 & 27 \\
\hline 18 & Washington & 1,952 & 10,331 & 248 & 760 & 1,096 & 14,196 & 734 & 592 & 27 \\
\hline 19 & Connecticut & 1,791 & 6,900 & 233 & 715 & 1,080 & 10,691 & 742 & 592 & 29 \\
\hline 20 & Wisconsin & 1,475 & 6,829 & 213 & 653 & 957 & 10,765 & 633 & 508 & 24 \\
\hline 21 & South Carolina & 1,306 & 8,900 & 163 & 499 & 933 & 14,770 & 606 & 420 & 29 \\
\hline 22 & Tennessee & 1,193 & 8,913 & 194 & 593 & 910 & 12,865 & 603 & 477 & 24 \\
\hline 23 & Nevada & 576 & 7,719 & 168 & 516 & 897 & 12,067 & 610 & 479 & 27 \\
\hline 24 & Minnesota & 1,501 & 5,883 & 184 & 562 & 877 & 9,570 & 576 & 459 & 23 \\
\hline 25 & Missouri & 1,468 & 8,936 & 202 & 619 & 676 & 9,667 & 450 & 380 & 11 \\
\hline 26 & Alabama & 833 & 6,994 & 131 & 402 & 627 & 10,027 & 405 & 318 & 16 \\
\hline 35 & Louisiana & 662 & 4,035 & 71 & 217 & 244 & 4,414 & 158 & 133 & 4 \\
\hline 36 & Arkansas & 435 & 2,916 & 54 & 166 & 240 & 3,980 & 154 & 123 & 6 \\
\hline 37 & Idaho & 453 & 2,205 & 52 & 159 & 239 & 3,404 & 156 & 124 & 6 \\
\hline 38 & Maine & 452 & 1,686 & 45 & 137 & 227 & 2,998 & 147 & 116 & 6 \\
\hline 39 & Rhode Island & 502 & 1,185 & 42 & 129 & 226 & 2,404 & 151 & 117 & 6 \\
\hline 40 & Delaware & 259 & 1,939 & 41 & 125 & 213 & 3,010 & 138 & 108 & 6 \\
\hline 41 & Nebraska & 540 & 2,064 & 52 & 159 & 199 & 2,626 & 129 & 107 & 4 \\
\hline 42 & New Mexico & 235 & 2,408 & 44 & 135 & 184 & 3,121 & 121 & 98 & 4 \\
\hline 43 & Mississippi & 429 & 2,210 & 37 & 114 & 168 & 2,995 & 106 & 85 & 4 \\
\hline 44 & West Virginia & 229 & 1,822 & 37 & 114 & 141 & 2,245 & 92 & 76 & 3 \\
\hline 45 & Vermont & 282 & 726 & 24 & 73 & 111 & 1,264 & 72 & 58 & 3 \\
\hline 46 & Montana & 254 & 641 & 16 & 48 & 62 & 872 & 39 & 32 & 1 \\
\hline 47 & Wyoming & 164 & 437 & 15 & 46 & 62 & 682 & 40 & 32 & 1 \\
\hline 48 & Alaska & 93 & 349 & 14 & 42 & 46 & 400 & 31 & 26 & 1 \\
\hline 49 & South Dakota & 173 & 541 & 11 & 34 & 41 & 647 & 25 & 21 & 1 \\
\hline 50 & North Dakota & 149 & 345 & 8 & 25 & 31 & 442 & 20 & 16 & 1 \\
\hline
\end{tabular}

Note: export share values shown for TX, MN and NM were taken from 1999 Implan model data to correct unreasonably low values ( $<1 \%)$.

* Values expressed in 2004 dollars (GDP Implicit Price Deflator, US Dept. Commerce). 
Table 5-5. Economic Impacts of the U.S. Landscape Architecture Sector by State, 2002

\begin{tabular}{|c|c|c|c|c|c|c|c|c|c|c|}
\hline Rank & State & $\begin{array}{l}\text { Establish- } \\
\text { ments }\end{array}$ & $\begin{array}{c}\text { Employ- } \\
\text { ment }\end{array}$ & $\begin{array}{l}\text { Annual } \\
\text { Wages } \\
(\$ M n)^{*}\end{array}$ & $\begin{array}{l}\text { Output } \\
(\$ M n)^{*}\end{array}$ & $\begin{array}{l}\text { Output } \\
\text { Impacts } \\
(\$ M n)^{*}\end{array}$ & $\begin{array}{l}\text { Employ- } \\
\text { ment } \\
\text { Impacts } \\
\text { (jobs) }\end{array}$ & $\begin{array}{l}\text { Value } \\
\text { Added } \\
\text { Impacts } \\
(\$ M n)^{*}\end{array}$ & $\begin{array}{l}\text { Labor } \\
\text { Income } \\
\text { Impacts } \\
(\$ M n)^{*}\end{array}$ & $\begin{array}{c}\text { Indirect } \\
\text { Business } \\
\text { Tax } \\
\text { Impacts } \\
\text { (\$Mn)* }\end{array}$ \\
\hline & Total & 6,225 & 36,679 & 1,384 & 3,714 & 4,803 & 48,683 & 3,449 & 2,549 & 74 \\
\hline 1 & California & 894 & 7,923 & 287 & 771 & 1,102 & 11,294 & 785 & 601 & 20 \\
\hline 2 & Texas & 293 & 2,916 & 103 & 277 & 372 & 3,959 & 264 & 203 & 6 \\
\hline 5 & Michigan & 195 & 940 & 51 & 137 & 236 & 2,045 & 161 & 5 & 5 \\
\hline 6 & Massachusetts & 236 & 1,093 & 56 & 152 & 230 & 1,890 & 163 & 124 & 5 \\
\hline 7 & Colorado & 183 & 1,071 & 51 & 136 & 204 & 1,825 & 144 & 110 & 4 \\
\hline 8 & New York & 373 & 1,422 & 69 & 185 & 194 & 1,507 & 144 & 114 & 2 \\
\hline 9 & Pennsylvania & 263 & 1,317 & 50 & 135 & 183 & 1,844 & 130 & 100 & 3 \\
\hline 10 & New Jersey & 233 & 1,004 & 42 & 112 & 146 & 1,340 & 105 & 81 & 2 \\
\hline 15 & Ohio & 172 & 855 & 33 & 88 & 107 & 1,093 & 77 & 60 & 1 \\
\hline 16 & Wisconsin & 100 & 633 & 26 & 70 & 89 & 882 & 64 & 49 & 1 \\
\hline 17 & Maryland & 133 & 707 & 26 & 71 & 87 & 894 & 64 & 50 & 1 \\
\hline 18 & Washington & 171 & 618 & 24 & 65 & 85 & 846 & 61 & 47 & 1 \\
\hline 19 & Tennessee & 93 & 729 & 18 & 48 & 65 & 929 & 46 & 35 & 1 \\
\hline 20 & Connecticut & 96 & 427 & 20 & 53 & 62 & 523 & 46 & 36 & 1 \\
\hline 21 & Oregon & 84 & 543 & 16 & 43 & 58 & 735 & 42 & 32 & 1 \\
\hline 22 & Minnesota & 90 & 384 & 17 & 45 & 56 & 510 & 40 & 31 & 1 \\
\hline 23 & Hawaii & 34 & 365 & 14 & 39 & 46 & 454 & 33 & 26 & 1 \\
\hline 24 & Indiana & 102 & 382 & 14 & 36 & 44 & 477 & 32 & 25 & 1 \\
\hline 25 & South Carolina & 90 & 462 & 14 & 37 & 44 & 563 & 32 & 25 & 1 \\
\hline 26 & Alabama & 58 & 435 & 11 & 29 & 41 & 590 & 29 & 22 & 1 \\
\hline 35 & Kentucky & 53 & 264 & 7 & 19 & 20 & 274 & 15 & 12 & 0 \\
\hline 36 & New Hampshire & 29 & 110 & 5 & 14 & 18 & 157 & 13 & 10 & 0 \\
\hline 37 & Oklahoma & 49 & 238 & 6 & 17 & 17 & 249 & 13 & 10 & 0 \\
\hline 38 & Delaware & 25 & 123 & 4 & 10 & 16 & 184 & 11 & 8 & 0 \\
\hline 39 & Nebraska & 29 & 147 & 6 & 15 & 16 & 157 & 12 & 9 & 0 \\
\hline 40 & Arkansas & 30 & 147 & 6 & 15 & 15 & 155 & 11 & 9 & 0 \\
\hline 41 & Utah & 67 & 140 & 5 & 13 & 14 & 150 & 10 & 8 & 0 \\
\hline 42 & Idaho & 33 & 118 & 4 & 11 & 11 & 130 & 8 & 7 & 0 \\
\hline 43 & Vermont & 31 & 52 & 3 & 7 & 9 & 81 & 6 & 5 & 0 \\
\hline 44 & Rhode Island & 32 & 50 & 2 & 5 & 7 & 70 & 5 & 4 & 0 \\
\hline 45 & Alaska & 7 & 50 & 2 & 5 & 6 & 68 & 5 & 4 & 0 \\
\hline 46 & Montana & 31 & 50 & 2 & 5 & 6 & 60 & 4 & 3 & 0 \\
\hline 47 & West Virginia & 14 & 50 & 2 & 5 & 6 & 58 & 4 & 3 & 0 \\
\hline 48 & Wyoming & 16 & 50 & 2 & 5 & 5 & 53 & 4 & 3 & 0 \\
\hline 49 & South Dakota & 15 & 50 & 2 & 4 & 4 & 52 & 3 & 3 & 0 \\
\hline 50 & North Dakota & 8 & 8 & 0 & 1 & 1 & 10 & 1 & 1 & 0 \\
\hline
\end{tabular}

* Values expressed in 2004 dollars (GDP Implicit Price Deflator, US Dept. Commerce). 


\section{Results for the Wholesale and Retail Trade Sectors}

A total of seven sectors comprise the U.S. horticultural wholesale and retail trade industries: 1) wholesale flower, nursery stock \& florist supply; 2) wholesale lawn \& garden equipment; 3) retail lawn and garden supply stores; 4) retail building materials and supply stores; 5) florists; 6) retail food and beverage stores; and 7) retail general merchandise stores. The first two sectors are wholesale establishments that provide horticultural products and services to the retail sector, including plant material, chemical and fertilizer supplies, and various types of lawn and garden equipment. Retail lawn and garden supply stores are independent and chain stores that sell primarily horticultural goods and services to end consumers. Retail building materials and supply stores are largely home improvement centers, such as Lowes, Home Depot, and Ace Hardware, all of which have lawn and garden centers. Retail food and beverage stores focus mostly on food items, but increasingly are including a floral section and seasonal landscape plant material. Examples of these stores are Albertson's, Publix, Safeway, Winn Dixie, and Kroger. The last category, retail general merchandise stores would include large chain stores such as WalMart and Target.

Table 6-1 presents summary information on the number of establishments, paid employees, annual payroll, and output gross margin for the seven industry sectors for horticultural goods. More than 116,000 establishments represent the wholesale and retail trade sectors. In terms of employment, two sectors accounted for 55 percent of all employees $(510,512)$ hired by the industry. The largest of these was the retail lawn and garden supply stores which accounted for one third $(171,149)$ of the total, followed by florists with nearly 113,929 (22 percent of the total). Sectors with the smallest number of paid workers were the retail food and beverage stores, and wholesale lawn and garden equipment stores. Annual payroll ranged from a high of $\$ 3.9$ billion for the retail lawn and garden supply stores to a low of $\$ 343$ million for retail food and beverage stores. In terms of per capita compensation (annual payroll divided by number employees), the two wholesale sectors paid nearly double the wages of the five retail sectors. Output gross margins varied from a high of $\$ 9.5$ billion for retail lawn and garden supply stores to a low of $\$ 917$ million for retail food and beverage stores. Output gross margin generated per employee averaged $\$ 45,000$ for all seven sectors, but ranged from a low of $\$ 25,000$ for florists to a high of $\$ 110,000$ for wholesale lawn and garden equipment stores.

\section{Table 6-1. Output, Employment and Payroll in the U.S. Environmental Horticulture Wholesale and Retail Trade Sectors, 2002}

\begin{tabular}{lrrrr}
\multicolumn{1}{c}{ Industry Sector } & $\begin{array}{c}\text { Establish- } \\
\text { ments }\end{array}$ & $\begin{array}{c}\text { Paid } \\
\text { Employees }\end{array}$ & $\begin{array}{c}\text { Annual } \\
\text { Payroll } \\
(\$ \mathrm{Mn})\end{array}$ & $\begin{array}{c}\text { Output- } \\
\text { Gross } \\
\text { Margin on } \\
\text { Sales } \\
(\$ \mathrm{Mn})\end{array}$ \\
\hline Wholesale Flower, Nursery Stock \& Florist Supply & 4,816 & 60,010 & 1,645 & 2,094 \\
Wholesale Lawn \& Garden Equipment & 4,041 & 29,102 & 984 & 3,187 \\
Retail Lawn and Garden Supply Stores & 21,065 & 171,149 & 3,922 & 9,503 \\
Retail Building Materials and Supply Stores * & 18,623 & 60,450 & 1,673 & 4,108 \\
Florists & 22,753 & 113,929 & 1,550 & 2,904 \\
Retail Food and Beverage Stores* & 22,465 & 19,222 & 343 & 917 \\
Retail General Merchandise Stores Sector* & 22,710 & 56,651 & 993 & 2,544 \\
Total Wholesale and Retail Trade & $\mathbf{1 1 6 , 4 7 3}$ & $\mathbf{5 1 0 , 5 1 2}$ & $\mathbf{1 1 , 1 1 0}$ & $\mathbf{2 5 , 2 5 7}$ \\
\hline
\end{tabular}

*Estimated payroll and employment proportional to merchandise or product line sales as share of total sales. Sources: 2002 Economic Census (US Census Bureau)

Economic impacts of the U.S. wholesale and retail trade sectors for horticultural goods are presented in Table 6-2. This industry group accounted for 37 percent of total output impacts of the U.S. Green Industry, and nearly half (47 percent) of all jobs. It also contributed over \$35 billion in value added, representing 37 percent of the Green Industry total. Of the seven sectors comprising the wholesale and retail trade industry, retail lawn and garden supply stores were the most prominent, comprising 42 percent of output impacts, 47 percent of all jobs, and paying 70 percent of all indirect business taxes. The second most important group was the retail building materials and supply stores, contributing nearly one-fifth of output impacts, 14 percent of employment, and 17 
percent of indirect business taxes. Together, these two groups comprised 60 percent of output impacts, just over half of all jobs, and paid 55 percent of indirect business taxes. Florists were the third largest contributing group, followed by retail general merchandise stores, wholesale lawn and garden equipment, wholesale flower, nursery stock and florist supply, and finally retail food and beverage stores.

Table 6-2. Economic Impacts of the U.S. Environmental Horticulture Wholesale and Retail Trade Sectors, 2002

\begin{tabular}{lrrrrr}
\multicolumn{1}{c}{ Industry Sector } & $\begin{array}{c}\text { Output } \\
\text { Impacts } \\
(\mathbf{\$ M n})^{*}\end{array}$ & $\begin{array}{c}\text { Employ- } \\
\text { ment } \\
\text { (jobs) }\end{array}$ & $\begin{array}{c}\text { Value } \\
\text { Added } \\
(\mathbf{M n})^{*}\end{array}$ & $\begin{array}{c}\text { Labor } \\
\text { Income } \\
(\mathbf{\$ M n})^{*}\end{array}$ & $\begin{array}{c}\text { Indirect } \\
\text { Business } \\
\text { Taxes } \\
(\mathbf{\$ M n})^{*}\end{array}$ \\
\hline Wholesale Flower, Nursery Stock \& Florist Supply & 2,879 & 68,969 & 1,907 & 1,130 & 440 \\
Wholesale Lawn \& Garden Equipment & 4,146 & 40,617 & 2,737 & 1,601 & 657 \\
Retail Lawn and Garden Supply Stores & 22,859 & 347,916 & 14,806 & 9,747 & 1,810 \\
Retail Building Materials and Supply Stores & 9,982 & 123,591 & 6,491 & 4,258 & 789 \\
Florists & 7,195 & 200,451 & 3,977 & 2,725 & 401 \\
Retail Food and Beverage Stores & 2,263 & 35,117 & 1,385 & 944 & 156 \\
Retail General Merchandise Stores Sector & 6,150 & 93,443 & 3,973 & 2,639 & 448 \\
Total Wholesale and Retail Trade & $\mathbf{5 5 , 4 7 4}$ & $\mathbf{9 1 0 , 1 0 4}$ & $\mathbf{3 5 , 2 7 6}$ & $\mathbf{2 3 , 0 4 4}$ & $\mathbf{4 , 7 0 1}$ \\
\hline
\end{tabular}

* Values expressed in 2004 dollars (GDP Implicit Price Deflator, US Dept. Commerce)

\section{Wholesale Flower, Nursery Stock \& Florist Supply}

Economic impacts of the wholesale flower, nursery stock \& florist supply sector by state are presented in Table 63. Nationally, $\$ 2.87$ billion was generated in output impacts, nearly 69,000 jobs, $\$ 1.90$ billion in value added, and $\$ 440$ million paid in taxes. These figures represent roughly 5 percent of economic activity from the seven trade sectors comprising ornamental horticulture-related firms. The top five states for this group were California, Florida, Illinois, New Jersey, and Texas. Together these states accounted for over half of the national output impacts, as well as over half of all jobs and indirect business taxes paid. The next five states in terms of importance are Ohio, New York, Georgia, Pennsylvania, and Massachusetts, comprising roughly an additional 20 percent in each of the impacts mentioned. In other words, the top 10 producing states accounted for nearly threequarters of total national economic impacts and jobs. Finally, the top 20 states constituted nearly 90 percent output, employment, value added, and indirect business taxes.

\section{Wholesale Lawn \& Garden Equipment Distributors}

Statewide economic impacts of the wholesale lawn \& garden equipment sector are presented in Table 6-4.

Nationally, this sector generated over $\$ 4$ billion in output impacts, employed over 40,000 people, contributed $\$ 2.7$ billion in value added impacts, and paid $\$ 657$ million in indirect business taxes, representing roughly 7 percent of the total for all seven sectors. The top five states for this group were California, Illinois, Texas, Ohio, and Minnesota, together comprising nearly one-third of the national total in each of the four impact categories mentioned. The next five states in terms of importance were Iowa, Georgia, Wisconsin, North Carolina, and Nebraska. This group contributed roughly one-fifth of the national totals, indicating that the top 10 states generated half of all output, employment, value added, and indirect business taxes. The top 20 states accounted for an additional 25 percent in each of the impact categories mentioned, representing approximately 75 percent of the national totals. 


\section{Retail Lawn and Garden Supply Stores}

Economic impacts of the retail lawn and garden supply stores are presented in Table 6-5. For the U.S. as a whole, this sector accounted for nearly $\$ 23$ billion in output impacts, 347,916 jobs, contributed $\$ 14.8$ billion in value added impacts, and paid $\$ 1.8$ billion in indirect business taxes. These figures represent roughly 40 percent of total economic impacts for the wholesale/retail trade group, making it the largest of the seven horticultural industry sectors. At the state level, the top five states for this sector were California, Texas, Illinois, New York, and Pennsylvania. These five states contributed 31 percent of total output impacts, over one-fourth of all jobs, and nearly one-third of value added impacts and taxes. The next five states in terms of economic importance were Ohio, Michigan, Wisconsin, Florida, and Minnesota. These states contributed an additional 15 percent in each impact category, suggesting the top 10 states produced just under half of national totals. The next top 10 states added an additional 25 percent to each impact category, indicating that the top 20 states contributed roughly three-quarters of national economic impacts.

\section{Retail Building Materials and Supply Stores}

Table 6-6 presents state-level economic impact results for retail building materials and supply stores. This sector includes home improvement stores such as Lowe's and Home Depot that, in addition to building supplies, have fairly sizable nursery and garden supply centers. Nationally, this sector generated just under $\$ 10$ billion in output impacts and $\$ 6.5$ billion in value added, supported 123,591 jobs, and paid $\$ 789$ million in indirect business taxes. As a share of total economic activity from the seven sectors, this group contributed approximately 18 percent. The top five states were California, Texas, Florida, New York, and Illinois. These top tier states contributed over one third of total U.S. economic impacts and taxes for the building materials and supply sector. The second tier of five states included Pennsylvania, Georgia, Michigan, Ohio and New Jersey. These states contributed an additional 18 percent share of economic impacts, indicating that the top 10 states comprised roughly half of the total for each measure. The next 10 states represented another 25 percent of the national total, making the top 20 states responsible for just over three-quarters of national output for the building materials and supply sector.

\section{Florists}

Information on the economic impacts of the U.S. florist industry is shown in Table 6-7. Nationally, this sector accounted for $\$ 7.2$ billion in output impacts, supported 200,451 jobs, and paid over $\$ 400$ million in indirect business taxes. As a share of total activity from the seven horticultural sectors, output impacts from florists represented 13 percent while the share of jobs was 22 percent, making it the second largest sector. In terms of state level impacts, the top five states were California, New York, Texas, Florida, and Illinois, accounting for just over one-third of total national impacts. The second tier of top five states was Pennsylvania, Ohio, Michigan, Massachusetts, and New Jersey. This group comprised around 20 percent of the total so that, when combined with the first top five, the top 10 states accounted for over half of all output. The next 10 states represented 25 percent of national output for the florist industry, making the top 20 comprising between 75 and 80 percent of the total.

\section{Retail Food and Beverage Stores}

State level economic impacts of the U.S. retail food and beverage industry are presented in Table 6-8. For the country as a whole, this group accounted for under 5 percent of economic impacts, making it the smallest of the seven sectors. This rather small share is due to the fact that most food retailers concentrate on cut flower arrangements rather than a full selection of ornamental plant products and services. In addition, although this is an increasing trend for grocery chain stores to incorporate flower shops, many still do not provide this service. Nationally, this sector contributed nearly $\$ 2.3$ billion in output impacts, $\$ 1.4$ billion in value added impacts, supported over 35,000 employee positions, and paid \$156 million in indirect business taxes. The top five producing states were California, Texas, Florida, New York, and Pennsylvania, which together accounted for approximately 40 percent of total U.S. impacts. The second most important five states were New Jersey, Illinois, 
Ohio, Massachusetts, and Georgia, comprising an additional 15 to 20 percent. Hence, the top 10 states accounted for between 55 and 60 percent of U.S. economic impacts for this sector. The next most important top 10 states represented an additional 20 to 25 percent share, making the top 20 states responsible for over three-quarters of nation-wide impacts.

\section{Retail General Merchandise Stores}

Table 6-9 presents information on state level economic impacts for the retail general merchandise stores. These would include big box stores like Wal-Mart and Target that also have garden center departments. These stores accounted for approximately 10 percent of total economic impacts of horticultural goods and services nationwide. Nationally, output impacts were estimated at $\$ 6.1$ billion, value added impacts at nearly $\$ 4$ billion, the number of people employed estimated at over 93,000, with $\$ 448$ million paid in indirect business taxes. At the state level, the top five states were California, Texas, Florida, Illinois, and New York, representing between 25 and 30 percent of U.S. impacts, depending on the specific indicator. For instance, these top five states accounted for one quarter of output impacts, but one-third of all jobs for the sector. The second tier of top five states were Michigan, Pennsylvania, Ohio, Georgia, and Missouri, comprising an additional 18 percent. Therefore, the top 10 states were responsible for between 45-50 percent of all economic impacts in the U.S. The next top 10 states accounted for another 20 to 25 percent, making the top 20 states accountable for between 65 and 70 percent of the total. 
Table 6-3. Economic Impacts of the U.S. Wholesale Flower, Nursery Stock \& Florist Supply Sector by State, 2002

\begin{tabular}{|c|c|c|c|c|c|c|c|c|c|c|}
\hline State & $\begin{array}{l}\text { Establish- } \\
\text { ments }\end{array}$ & $\begin{array}{c}\text { Employ- } \\
\text { ment } \\
\text { (jobs) }\end{array}$ & $\begin{array}{l}\text { Annual } \\
\text { Wages } \\
(\$ M n)^{*}\end{array}$ & $\begin{array}{c}\text { Output } \\
\text { Gross } \\
\text { Margin } \\
\text { on } \\
\text { Sales } \\
(\$ M n)^{*}\end{array}$ & $\begin{array}{l}\text { Output } \\
\text { Impacts } \\
(\$ M n)^{*}\end{array}$ & $\begin{array}{l}\text { Employ } \\
\text { ment } \\
\text { Impacts } \\
\text { (jobs) }\end{array}$ & $\begin{array}{l}\text { Value } \\
\text { Added } \\
\text { Impacts } \\
(\$ M n)^{*}\end{array}$ & $\begin{array}{l}\text { Labor } \\
\text { Income } \\
\text { Impacts } \\
(\$ M n)^{*}\end{array}$ & $\begin{array}{l}\text { Indirect } \\
\text { Business } \\
\text { Tax } \\
\text { Impacts } \\
(\$ M n)^{*}\end{array}$ & $\begin{array}{l}\text { Export } \\
\text { Share }\end{array}$ \\
\hline Total & 4,816 & 60,010 & 1,645 & 2,094 & 2,879 & 68,969 & 1,907 & 1,130 & 440 & \\
\hline California & 763 & 10,985 & 319 & 406 & 485 & 11,793 & 324 & 191 & 82 & $11.2 \%$ \\
\hline Florida & 679 & 8,080 & 235 & 299 & 446 & 9,868 & 294 & 178 & 65 & $30.5 \%$ \\
\hline Illinois & 196 & 3,580 & 120 & 153 & 224 & 4,327 & 147 & 89 & 33 & $27.5 \%$ \\
\hline New Jersey & 172 & 2,813 & 95 & 121 & 198 & 3,590 & 133 & 82 & 27 & $48.1 \%$ \\
\hline Texas & 328 & 3,885 & 93 & 119 & 169 & 4,445 & 111 & 67 & 26 & $26.7 \%$ \\
\hline Ohio & 145 & 2,409 & 61 & 77 & 159 & 3,416 & 101 & 63 & 18 & $90.8 \%$ \\
\hline New York & 297 & 2,697 & 92 & 117 & 156 & 3,093 & 105 & 63 & 25 & $26.3 \%$ \\
\hline Georgia & 164 & 1,752 & 51 & 65 & 101 & 2,169 & 67 & 41 & 14 & $35.1 \%$ \\
\hline Pennsylvania & 156 & 2,059 & 52 & 66 & 76 & 2,167 & 50 & 29 & 13 & $9.7 \%$ \\
\hline Massachusetts & 97 & 1,243 & 40 & 51 & 73 & 1,474 & 49 & 30 & 11 & $30.3 \%$ \\
\hline Michigan & 132 & 1,369 & 37 & 47 & 65 & 1,576 & 43 & 10 & 10 & $28.8 \%$ \\
\hline Washington & 138 & 1,471 & 41 & 52 & 61 & 1,577 & 41 & 24 & 10 & $14.5 \%$ \\
\hline Arizona & 79 & 1,284 & 28 & 36 & 56 & 1,534 & 37 & 22 & 8 & $38.7 \%$ \\
\hline Maryland & 70 & 1,056 & 27 & 34 & 54 & 1,293 & 37 & 23 & 7 & $36.7 \%$ \\
\hline Colorado & 64 & 954 & 24 & 30 & 42 & 1,095 & 28 & 17 & 6 & $24.2 \%$ \\
\hline North Carolina & 145 & 1,124 & 27 & 35 & 41 & 1,199 & 27 & 16 & 7 & $12.7 \%$ \\
\hline Minnesota & 73 & 923 & 23 & 30 & 40 & 1,039 & 26 & 16 & 6 & $20.9 \%$ \\
\hline Missouri & 61 & 1,192 & 22 & 28 & 33 & 1,244 & 22 & 13 & 6 & $9.7 \%$ \\
\hline South Carolina & 64 & 842 & 20 & 25 & 32 & 936 & 21 & 12 & 5 & $23.7 \%$ \\
\hline Connecticut & 55 & 574 & 16 & 21 & 29 & 655 & 19 & 12 & 4 & $28.9 \%$ \\
\hline Virginia & 67 & 755 & 16 & 20 & 29 & 863 & 20 & 12 & 4 & $30.3 \%$ \\
\hline Oregon & 77 & 652 & 18 & 23 & 28 & 719 & 19 & 11 & 5 & $17.6 \%$ \\
\hline Alabama & 64 & 741 & 16 & 21 & 26 & 809 & 17 & 10 & 4 & $20.8 \%$ \\
\hline Tennessee & 88 & 753 & 18 & 23 & 26 & 791 & 17 & 10 & 5 & $9.7 \%$ \\
\hline Indiana & 73 & 756 & 18 & 22 & 25 & 793 & 17 & 10 & 4 & $10.3 \%$ \\
\hline Wisconsin & 69 & 656 & 18 & 23 & 25 & 691 & 17 & 10 & 4 & $9.7 \%$ \\
\hline Oklahoma & 34 & 644 & 13 & 17 & 19 & 674 & 12 & 7 & 3 & $9.7 \%$ \\
\hline Kansas & 23 & 472 & 11 & 15 & 16 & 496 & 11 & 6 & 3 & $9.7 \%$ \\
\hline Kentucky & 51 & 519 & 12 & 15 & 16 & 538 & 11 & 6 & 3 & $9.7 \%$ \\
\hline Mississippi & 39 & 577 & 11 & 14 & 15 & 598 & 10 & 6 & 3 & $9.7 \%$ \\
\hline Louisiana & 44 & 493 & 9 & 11 & 14 & 539 & 9 & 6 & 2 & $23.9 \%$ \\
\hline Hawaii & 34 & 321 & 7 & 9 & 10 & 343 & 7 & 4 & 2 & $13.4 \%$ \\
\hline Nevada & 25 & 151 & 4 & 6 & 9 & 186 & 6 & 4 & 1 & $45.0 \%$ \\
\hline Rhode Island & 7 & 177 & 5 & 6 & 9 & 214 & 6 & 4 & 1 & $46.8 \%$ \\
\hline Utah & 31 & 269 & 6 & 8 & 9 & 286 & 6 & 4 & 2 & $9.7 \%$ \\
\hline New Hampshire & 18 & 123 & 4 & 5 & 8 & 160 & 5 & 3 & 1 & $49.8 \%$ \\
\hline South Dakota & 11 & 228 & 6 & 8 & 8 & 240 & 6 & 3 & 1 & $9.7 \%$ \\
\hline Arkansas & 28 & 248 & 5 & 6 & 7 & 257 & 4 & 3 & 1 & $9.7 \%$ \\
\hline Iowa & 27 & 242 & 5 & 6 & 7 & 252 & 5 & 3 & 1 & $9.7 \%$ \\
\hline Delaware & 10 & 154 & 3 & 4 & 6 & 179 & 4 & 2 & 1 & $53.6 \%$ \\
\hline Nebraska & 15 & 155 & 3 & 4 & 4 & 162 & 3 & 2 & 1 & $9.7 \%$ \\
\hline West Virginia & 15 & 141 & 3 & 4 & 4 & 146 & 3 & 1 & 1 & $11.1 \%$ \\
\hline Idaho & 15 & 93 & 2 & 2 & 3 & 99 & 2 & 1 & 0 & $14.8 \%$ \\
\hline Montana & 8 & 73 & 2 & 2 & 3 & 86 & 2 & 1 & 0 & $33.4 \%$ \\
\hline New Mexico & 17 & 95 & 2 & 3 & 3 & 100 & 2 & 1 & 1 & $9.7 \%$ \\
\hline Vermont & 12 & 51 & 1 & 2 & 3 & 62 & 2 & 1 & 0 & $38.5 \%$ \\
\hline Alaska & 6 & 51 & 1 & 2 & 2 & 53 & 1 & 1 & 0 & $9.7 \%$ \\
\hline Maine & 13 & 51 & 1 & 2 & 2 & 58 & 2 & 1 & 0 & $25.4 \%$ \\
\hline Wyoming & 5 & 51 & 1 & 2 & 2 & 55 & 1 & 1 & 0 & $16.0 \%$ \\
\hline North Dakota & 7 & 28 & 0 & 1 & 1 & 32 & 1 & 0 & 0 & $45.5 \%$ \\
\hline
\end{tabular}


Table 6-4. Economic Impacts of the U.S. Wholesale Lawn \& Garden Equipment Sector by State, 2002

\begin{tabular}{|c|c|c|c|c|c|c|c|c|c|c|}
\hline State & $\begin{array}{l}\text { Establish- } \\
\text { ments }\end{array}$ & $\begin{array}{c}\text { Employ- } \\
\text { ment }\end{array}$ & $\begin{array}{c}\text { Annual } \\
\text { Wages } \\
(\$ M n) \\
*\end{array}$ & $\begin{array}{c}\text { Output } \\
\text { Gross } \\
\text { Margin } \\
\text { on } \\
\text { Sales } \\
\text { (\$Mn) } \\
*\end{array}$ & $\begin{array}{l}\text { Output } \\
\text { Impacts } \\
(\$ M n)^{*}\end{array}$ & $\begin{array}{l}\text { Employ- } \\
\text { ment } \\
\text { Impacts } \\
\text { (jobs) }\end{array}$ & $\begin{array}{l}\text { Value } \\
\text { Added } \\
\text { Impacts } \\
(\$ M n)^{*}\end{array}$ & $\begin{array}{l}\text { Labor } \\
\text { Income } \\
\text { Impacts } \\
(\$ M n)^{*}\end{array}$ & $\begin{array}{c}\text { Indirect } \\
\text { Business } \\
\text { Tax } \\
\text { Impacts } \\
(\$ M n)^{*}\end{array}$ & $\begin{array}{c}\text { Export } \\
\text { Share }\end{array}$ \\
\hline Total & 4,041 & 29,102 & 984 & 3,187 & 4,146 & 40,617 & 2,737 & 1,601 & 657 & \\
\hline California & 288 & 2,040 & 77 & 249 & 297 & 2,536 & 199 & 117 & 50 & $11.2 \%$ \\
\hline Illinois & 184 & 1,649 & 60 & 194 & 284 & 2,597 & 187 & 113 & 42 & $27.5 \%$ \\
\hline Texas & 294 & 1,857 & 60 & 194 & 276 & 2,768 & 181 & 109 & 42 & $26.7 \%$ \\
\hline Ohio & 144 & 1,166 & 38 & 124 & 255 & 2,787 & 163 & 102 & 29 & $90.8 \%$ \\
\hline Minnesota & 184 & 1,395 & 51 & 164 & 220 & 2,036 & 145 & 86 & 34 & $20.9 \%$ \\
\hline Iowa & 229 & 1,593 & 51 & 165 & 183 & 1,844 & 121 & 70 & 33 & $9.7 \%$ \\
\hline Georgia & 115 & 918 & 31 & 100 & 156 & 1,560 & 103 & 63 & 22 & $35.1 \%$ \\
\hline Wisconsin & 173 & 1,264 & 42 & 138 & 154 & 1,482 & 102 & 60 & 27 & $9.7 \%$ \\
\hline North Carolina & 106 & 862 & 40 & 130 & 152 & 1,141 & 101 & 59 & 26 & $12.7 \%$ \\
\hline Nebraska & 142 & 1,104 & 35 & 113 & 127 & 1,305 & 84 & 49 & 22 & $9.7 \%$ \\
\hline Florida & 146 & 717 & 25 & 80 & 119 & 1,195 & 79 & 48 & 17 & $30.5 \%$ \\
\hline Kansas & 122 & 974 & 33 & 106 & 119 & 1,150 & 79 & 46 & 21 & $9.7 \%$ \\
\hline Michigan & 100 & 817 & 26 & 85 & 117 & 1,187 & 77 & 18 & 18 & $28.8 \%$ \\
\hline Missouri & 128 & 961 & 29 & 94 & 107 & 1,133 & 71 & 41 & 19 & $9.7 \%$ \\
\hline Indiana & 117 & 864 & 29 & 94 & 106 & 1,018 & 70 & 41 & 19 & $10.3 \%$ \\
\hline New York & 112 & 667 & 23 & 75 & 100 & 920 & 67 & 40 & 16 & $26.3 \%$ \\
\hline Pennsylvania & 120 & 807 & 26 & 85 & 97 & 944 & 65 & 38 & 17 & $9.7 \%$ \\
\hline North Dakota & 83 & 618 & 20 & 66 & 95 & 1,059 & 61 & 37 & 14 & $45.5 \%$ \\
\hline Washington & 70 & 594 & 20 & 66 & 78 & 730 & 52 & 30 & 13 & $14.5 \%$ \\
\hline Tennessee & 84 & 636 & 21 & 68 & 77 & 748 & 51 & 29 & 13 & $9.7 \%$ \\
\hline Colorado & 66 & 494 & 17 & 54 & 76 & 746 & 50 & 30 & 11 & $24.2 \%$ \\
\hline Arkansas & 88 & 653 & 21 & 68 & 75 & 753 & 49 & 29 & 13 & $9.7 \%$ \\
\hline Virginia & 70 & 496 & 16 & 50 & 73 & 762 & 48 & 30 & 11 & $30.3 \%$ \\
\hline Oregon & 59 & 408 & 14 & 47 & 58 & 546 & 38 & 23 & 10 & $17.6 \%$ \\
\hline New Jersey & 39 & 233 & 10 & 33 & 54 & 444 & 36 & 22 & 7 & $48.1 \%$ \\
\hline Idaho & 59 & 423 & 14 & 44 & 52 & 539 & 34 & 20 & 9 & $14.8 \%$ \\
\hline Arizona & 38 & 236 & 10 & 31 & 49 & 454 & 32 & 20 & 7 & $38.7 \%$ \\
\hline Louisiana & 50 & 443 & 12 & 38 & 49 & 602 & 32 & 19 & 8 & $23.9 \%$ \\
\hline South Dakota & 60 & 426 & 13 & 44 & 48 & 497 & 32 & 18 & 9 & $9.7 \%$ \\
\hline Alabama & 72 & 405 & 12 & 38 & 47 & 529 & 31 & 18 & 8 & $20.8 \%$ \\
\hline Maryland & 30 & 254 & 9 & 29 & 47 & 457 & 31 & 20 & 6 & $36.7 \%$ \\
\hline Oklahoma & 67 & 434 & 13 & 41 & 46 & 510 & 31 & 18 & 8 & $9.7 \%$ \\
\hline Kentucky & 76 & 440 & 13 & 41 & 45 & 494 & 30 & 17 & 8 & $9.7 \%$ \\
\hline Mississippi & 57 & 381 & 12 & 39 & 43 & 439 & 28 & 16 & 8 & $9.7 \%$ \\
\hline Connecticut & 11 & 169 & 8 & 24 & 34 & 264 & 23 & 14 & 5 & $28.9 \%$ \\
\hline Montana & 39 & 248 & 7 & 24 & 32 & 375 & 21 & 12 & 5 & $33.4 \%$ \\
\hline Massachusetts & 22 & 142 & 7 & 22 & 31 & 240 & 21 & 13 & 5 & $30.3 \%$ \\
\hline South Carolina & 44 & 246 & 7 & 23 & 29 & 330 & 19 & 11 & 5 & $23.7 \%$ \\
\hline Utah & 29 & 294 & 7 & 24 & 28 & 347 & 18 & 11 & 5 & $9.7 \%$ \\
\hline Nevada & 12 & 114 & 4 & 12 & 19 & 190 & 13 & 8 & 3 & $45.0 \%$ \\
\hline Delaware & 9 & 100 & 3 & 10 & 16 & 170 & 10 & 6 & 2 & $53.6 \%$ \\
\hline Wyoming & 13 & 114 & 4 & 12 & 14 & 143 & 9 & 5 & 3 & $16.0 \%$ \\
\hline New Hampshire & 11 & 66 & 2 & 8 & 13 & 128 & 8 & 5 & 2 & $49.8 \%$ \\
\hline New Mexico & 21 & 123 & 3 & 11 & 12 & 143 & 8 & 5 & 2 & $9.7 \%$ \\
\hline Maine & 16 & 83 & 2 & 8 & 10 & 117 & 7 & 4 & 2 & $25.4 \%$ \\
\hline Vermont & 14 & 68 & 2 & 7 & 10 & 115 & 7 & 4 & 1 & $38.5 \%$ \\
\hline Hawaii & 7 & 35 & 2 & 6 & 7 & 49 & 5 & 3 & 1 & $13.4 \%$ \\
\hline West Virginia & 14 & 53 & 2 & 6 & 6 & 61 & 4 & 2 & 1 & $11.1 \%$ \\
\hline Rhode Island & 4 & 18 & 1 & 2 & 3 & 30 & 2 & 1 & 0 & $46.8 \%$ \\
\hline Alaska & 1 & 3 & 0 & 0 & 0 & 3 & 0 & 0 & 0 & $9.7 \%$ \\
\hline
\end{tabular}

* Values expressed in 2004 dollars (GDP Implicit Price Deflator, US Dept. Commerce). 
Table 6-5. Economic Impacts of the U.S. Retail Lawn and Garden Supply Stores Sector by State, 2002

\begin{tabular}{|c|c|c|c|c|c|c|c|c|c|}
\hline State & $\begin{array}{l}\text { Establish- } \\
\text { ments }\end{array}$ & $\begin{array}{c}\text { Employ- } \\
\text { ment }\end{array}$ & $\begin{array}{l}\text { Annual } \\
\text { Wages } \\
(\$ M n)^{*}\end{array}$ & $\begin{array}{c}\text { Output } \\
\text { Gross } \\
\text { Margin on } \\
\text { Sales } \\
(\$ M n)^{*}\end{array}$ & $\begin{array}{l}\text { Output } \\
\text { Impacts } \\
(\$ M n)^{*}\end{array}$ & $\begin{array}{l}\text { Employ- } \\
\text { ment } \\
\text { Impacts } \\
\text { (jobs) }\end{array}$ & $\begin{array}{l}\text { Value } \\
\text { Added } \\
\text { Impacts } \\
(\$ M n)^{*}\end{array}$ & $\begin{array}{l}\text { Labor } \\
\text { Income } \\
\text { Impacts } \\
(\$ M n)^{*}\end{array}$ & $\begin{array}{c}\text { Indirect } \\
\text { Business } \\
\text { Tax Impacts } \\
(\$ M n)^{*}\end{array}$ \\
\hline Total & 21,065 & 171,149 & 3,922 & 9,503 & 22,859 & 347,916 & 14,806 & $\mathbf{9 , 7 4 7}$ & 1,810 \\
\hline California & 1,459 & 14,272 & 383 & 928 & 2,517 & 31,352 & 1,657 & 1,131 & 191 \\
\hline Texas & 1,487 & 12,269 & 244 & 590 & 1,505 & 25,386 & 962 & 644 & 120 \\
\hline Illinois & 842 & 7,516 & 197 & 478 & 1,288 & 15,641 & 826 & 560 & 97 \\
\hline New York & 852 & 6,410 & 168 & 407 & 927 & 11,640 & 621 & 420 & 77 \\
\hline Pennsylvania & 914 & 6,636 & 137 & 331 & 830 & 13,186 & 531 & 357 & 65 \\
\hline Ohio & 884 & 6,972 & 153 & 370 & 821 & 13,103 & 524 & 353 & 64 \\
\hline Michigan & 688 & 5,339 & 133 & 323 & 756 & 10,617 & 485 & 60 & 60 \\
\hline Wisconsin & 603 & 5,798 & 136 & 329 & 751 & 11,567 & 478 & 324 & 60 \\
\hline Florida & 907 & 5,720 & 119 & 288 & 748 & 12,661 & 488 & 328 & 58 \\
\hline Minnesota & 611 & 4,705 & 115 & 279 & 728 & 10,018 & 464 & 314 & 56 \\
\hline Georgia & 619 & 5,042 & 110 & 268 & 690 & 11,400 & 453 & 305 & 55 \\
\hline Missouri & 658 & 5,621 & 111 & 269 & 674 & 12,056 & 430 & 289 & 53 \\
\hline Indiana & 659 & 5,324 & 119 & 288 & 654 & 10,323 & 412 & 276 & 53 \\
\hline Virginia & 540 & 5,400 & 108 & 261 & 647 & 11,014 & 427 & 292 & 50 \\
\hline Washington & 544 & 4,585 & 111 & 269 & 606 & 8,956 & 397 & 269 & 49 \\
\hline North Carolina & 736 & 5,157 & 105 & 256 & 592 & 10,365 & 382 & 258 & 48 \\
\hline Iowa & 588 & 4,227 & 111 & 268 & 569 & 8,092 & 362 & 243 & 47 \\
\hline Tennessee & 473 & 4,584 & 91 & 220 & 524 & 9,437 & 335 & 223 & 42 \\
\hline Colorado & 298 & 3,068 & 79 & 193 & 521 & 6,990 & 340 & 232 & 40 \\
\hline New Jersey & 459 & 3,018 & 79 & 191 & 443 & 5,907 & 297 & 202 & 36 \\
\hline Maryland & 273 & 2,987 & 67 & 163 & 427 & 6,641 & 288 & 200 & 32 \\
\hline Massachusetts & 327 & 2,392 & 70 & 170 & 417 & 5,038 & 279 & 191 & 33 \\
\hline Oregon & 342 & 3,115 & 72 & 174 & 407 & 6,381 & 265 & 178 & 33 \\
\hline Nebraska & 335 & 2,815 & 70 & 170 & 391 & 5,576 & 248 & 168 & 31 \\
\hline Kentucky & 457 & 3,742 & 78 & 189 & 385 & 6,725 & 245 & 165 & 33 \\
\hline Kansas & 312 & 2,958 & 64 & 156 & 357 & 5,791 & 225 & 151 & 29 \\
\hline Idaho & 201 & 2,093 & 64 & 155 & 337 & 4,559 & 220 & 149 & 28 \\
\hline Connecticut & 270 & 2,251 & 59 & 142 & 329 & 4,479 & 223 & 152 & 27 \\
\hline Arizona & 236 & 2,344 & 53 & 128 & 311 & 4,945 & 204 & 138 & 24 \\
\hline Louisiana & 350 & 2,656 & 50 & 122 & 271 & 5,256 & 174 & 118 & 22 \\
\hline Oklahoma & 325 & 2,443 & 44 & 107 & 252 & 4,951 & 159 & 107 & 20 \\
\hline Mississippi & 298 & 2,151 & 50 & 122 & 249 & 3,928 & 158 & 107 & 21 \\
\hline Arkansas & 319 & 2,137 & 46 & 112 & 232 & 3,844 & 146 & 98 & 19 \\
\hline South Carolina & 371 & 2,200 & 43 & 103 & 220 & 4,249 & 143 & 93 & 18 \\
\hline Alabama & 362 & 1,986 & 36 & 88 & 189 & 3,786 & 122 & 82 & 16 \\
\hline South Dakota & 186 & 1,435 & 35 & 86 & 181 & 2,693 & 114 & 78 & 15 \\
\hline Utah & 140 & 1,356 & 27 & 67 & 174 & 3,175 & 111 & 76 & 13 \\
\hline Montana & 128 & 1,279 & 25 & 61 & 122 & 2,372 & 78 & 53 & 10 \\
\hline New Hampshire & 128 & 859 & 22 & 52 & 121 & 1,844 & 79 & 54 & 10 \\
\hline Nevada & 72 & 885 & 20 & 49 & 109 & 1,745 & 73 & 49 & 9 \\
\hline North Dakota & 126 & 932 & 23 & 56 & 109 & 1,652 & 69 & 47 & 9 \\
\hline Maine & 131 & 766 & 16 & 38 & 81 & 1,508 & 53 & 36 & 7 \\
\hline New Mexico & 100 & 867 & 15 & 36 & 80 & 1,772 & 53 & 36 & 6 \\
\hline Vermont & 86 & 589 & 14 & 35 & 75 & 1,196 & 49 & 34 & 6 \\
\hline West Virginia & 130 & 792 & 14 & 33 & 62 & 1,328 & 39 & 27 & 5 \\
\hline Delaware & 64 & 478 & 12 & 29 & 60 & 876 & 39 & 26 & 5 \\
\hline Hawaii & 43 & 312 & 7 & 17 & 41 & 685 & 28 & 20 & 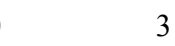 \\
\hline Wyoming & 66 & 358 & 8 & 20 & 39 & 639 & 25 & 17 & 3 \\
\hline Alaska & 24 & 167 & 4 & 9 & 19 & 307 & 13 & 9 & 2 \\
\hline Rhode Island & 43 & 143 & 4 & 9 & 18 & 265 & 12 & 8 & 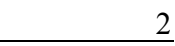 \\
\hline
\end{tabular}

* Values expressed in 2004 dollars (GDP Implicit Price Deflator, US Dept. Commerce). 
Table 6-6. Economic Impacts of the U.S. Retail Building Materials and Supply Stores Sector by State, 2002

\begin{tabular}{|c|c|c|c|c|c|c|c|c|c|}
\hline State & $\begin{array}{l}\text { Establish } \\
\text { ments }\end{array}$ & $\begin{array}{c}\text { Employ } \\
\text { ment } \\
\text { (jobs) }\end{array}$ & $\begin{array}{l}\text { Annual } \\
\text { Wages } \\
(\$ M n)^{*}\end{array}$ & $\begin{array}{c}\text { Output } \\
\text { Gross } \\
\text { Margin } \\
\text { on Sales } \\
(\$ M n)^{*}\end{array}$ & $\begin{array}{l}\text { Output } \\
\text { Impacts } \\
(\$ M n)^{*}\end{array}$ & $\begin{array}{l}\text { Employ- } \\
\text { ment } \\
\text { Impacts } \\
\text { (jobs) }\end{array}$ & $\begin{array}{l}\text { Value } \\
\text { Added } \\
\text { Impacts } \\
(\$ M n)^{*}\end{array}$ & $\begin{array}{l}\text { Labor } \\
\text { Income } \\
\text { Impacts } \\
(\$ M n)^{*}\end{array}$ & $\begin{array}{c}\text { Indirect } \\
\text { Business } \\
\text { Tax } \\
\text { Impacts } \\
(\$ M n)^{*}\end{array}$ \\
\hline Total & 18,623 & 60,450 & 1,673 & 4,108 & 9,982 & 123,591 & 6,491 & 4,258 & 789 \\
\hline California & 1,554 & 6,292 & 182 & 446 & 1,210 & 13,822 & 797 & 544 & 92 \\
\hline Texas & 1,118 & 4,178 & 112 & 275 & 703 & 8,645 & 449 & 301 & 56 \\
\hline Florida & 1,107 & 3,694 & 97 & 237 & 617 & 8,175 & 402 & 270 & 48 \\
\hline New York & 1,116 & 3,244 & 95 & 232 & 528 & 5,890 & 354 & 239 & 44 \\
\hline Illinois & 730 & 2,584 & 72 & 178 & 479 & 5,378 & 308 & 208 & 36 \\
\hline Pennsylvania & 803 & 2,446 & 66 & 162 & 407 & 4,859 & 260 & 175 & 32 \\
\hline Georgia & 552 & 2,073 & 61 & 149 & 384 & 4,687 & 252 & 170 & 30 \\
\hline Michigan & 745 & 2,351 & 66 & 162 & 380 & 4,675 & 244 & 30 & 30 \\
\hline Ohio & 784 & 2,472 & 65 & 160 & 355 & 4,645 & 226 & 153 & 28 \\
\hline New Jersey & 494 & 1,768 & 57 & 141 & 326 & 3,461 & 218 & 149 & 27 \\
\hline North Carolina & 613 & 1,999 & 55 & 134 & 311 & 4,018 & 201 & 136 & 25 \\
\hline Massachusetts & 412 & 1,414 & 48 & 118 & 291 & 2,978 & 194 & 133 & 23 \\
\hline Colorado & 339 & 1,184 & 37 & 91 & 247 & 2,697 & 161 & 110 & 19 \\
\hline Virginia & 414 & 1,486 & 40 & 99 & 244 & 3,030 & 161 & 110 & 19 \\
\hline Minnesota & 442 & 1,310 & 37 & 92 & 239 & 2,789 & 152 & 103 & 18 \\
\hline Maryland & 283 & 1,173 & 34 & 85 & 222 & 2,607 & 150 & 104 & 17 \\
\hline Missouri & 465 & 1,366 & 35 & 86 & 216 & 2,929 & 138 & 93 & 17 \\
\hline Wisconsin & 431 & 1,401 & 38 & 94 & 214 & 2,795 & 136 & 92 & 17 \\
\hline Indiana & 463 & 1,503 & 38 & 93 & 211 & 2,914 & 133 & 89 & 17 \\
\hline Tennessee & 410 & 1,225 & 34 & 83 & 198 & 2,521 & 127 & 84 & 16 \\
\hline Washington & 388 & 1,215 & 35 & 87 & 196 & 2,374 & 128 & 87 & 16 \\
\hline Arizona & 282 & 1,208 & 32 & 80 & 194 & 2,548 & 127 & 86 & 15 \\
\hline Connecticut & 235 & 847 & 28 & 68 & 159 & 1,685 & 107 & 73 & 13 \\
\hline South Carolina & 302 & 916 & 23 & 56 & 120 & 1,769 & 78 & 51 & 10 \\
\hline Alabama & 322 & 919 & 22 & 54 & 117 & 1,753 & 75 & 51 & 10 \\
\hline Oregon & 256 & 678 & 20 & 49 & 114 & 1,388 & 74 & 50 & 9 \\
\hline Louisiana & 290 & 874 & 20 & 50 & 110 & 1,730 & 71 & 48 & 9 \\
\hline Kentucky & 300 & 820 & 20 & 50 & 102 & 1,474 & 65 & 44 & 9 \\
\hline Iowa & 303 & 726 & 18 & 44 & 94 & 1,391 & 60 & 40 & 8 \\
\hline Utah & 159 & 524 & 15 & 36 & 94 & 1,227 & 60 & 41 & 7 \\
\hline Oklahoma & 234 & 615 & 15 & 36 & 86 & 1,245 & 54 & 36 & 7 \\
\hline Kansas & 239 & 592 & 15 & 37 & 85 & 1,159 & 53 & 36 & 7 \\
\hline New Hampshire & 126 & 397 & 12 & 30 & 70 & 852 & 45 & 31 & 6 \\
\hline Nevada & 103 & 406 & 12 & 30 & 66 & 801 & 44 & 30 & 5 \\
\hline Arkansas & 209 & 517 & 13 & 31 & 64 & 929 & 40 & 27 & 5 \\
\hline Nebraska & 183 & 440 & 11 & 27 & 61 & 871 & 39 & 26 & 5 \\
\hline Mississippi & 205 & 521 & 12 & 29 & 60 & 951 & 38 & 26 & 5 \\
\hline New Mexico & 128 & 361 & 10 & 23 & 53 & 739 & 34 & 24 & 4 \\
\hline Idaho & 137 & 339 & 9 & 21 & 46 & 739 & 30 & 20 & 4 \\
\hline Maine & 130 & 316 & 8 & 21 & 44 & 621 & 29 & 20 & 4 \\
\hline West Virginia & 135 & 347 & 8 & 20 & 37 & 582 & 24 & 16 & 3 \\
\hline Delaware & 62 & 234 & 6 & 15 & 31 & 430 & 20 & 14 & 3 \\
\hline Hawaii & 60 & 200 & 5 & 13 & 30 & 440 & 21 & 14 & 2 \\
\hline Alaska & 51 & 208 & 6 & 14 & 29 & 381 & 19 & 13 & 2 \\
\hline Montana & 130 & 251 & 6 & 14 & 29 & 465 & 18 & 12 & 2 \\
\hline Rhode Island & 58 & 179 & 6 & 14 & 28 & 331 & 19 & 13 & 2 \\
\hline Vermont & 78 & 164 & 5 & 12 & 26 & 334 & 17 & 11 & 2 \\
\hline South Dakota & 101 & 202 & 5 & 11 & 24 & 379 & 15 & 10 & 2 \\
\hline North Dakota & 84 & 177 & 4 & 11 & 21 & 314 & 14 & 9 & 2 \\
\hline Wyoming & 61 & 97 & 3 & 7 & 13 & 173 & 8 & 6 & 1 \\
\hline
\end{tabular}

* Values expressed in 2004 dollars (GDP Implicit Price Deflator, US Dept. Commerce). 
Table 6-7. Economic Impacts of the U.S. Florists Sector by State, 2002

\begin{tabular}{|c|c|c|c|c|c|c|c|c|c|}
\hline State & $\begin{array}{c}\text { Establish- } \\
\text { ments }\end{array}$ & $\begin{array}{c}\text { Employ- } \\
\text { ment }\end{array}$ & $\begin{array}{l}\text { Annual } \\
\text { Wages } \\
\text { (\$Mn)* }\end{array}$ & $\begin{array}{c}\text { Output } \\
\text { Gross } \\
\text { Margin on } \\
\text { Sales } \\
(\$ M n)^{*} \\
\end{array}$ & $\begin{array}{l}\text { Output } \\
\text { Impacts } \\
\text { (\$Mn)* }\end{array}$ & $\begin{array}{l}\text { Employ- } \\
\text { ment } \\
\text { Impacts } \\
\text { (jobs) }\end{array}$ & $\begin{array}{l}\text { Value } \\
\text { Added } \\
\text { Impacts } \\
(\$ M n)^{*}\end{array}$ & $\begin{array}{l}\text { Labor } \\
\text { Income } \\
\text { Impacts } \\
(\$ M n)^{*}\end{array}$ & $\begin{array}{l}\text { Indirect } \\
\text { Business } \\
\text { Tax } \\
\text { Impacts } \\
(\$ M n)^{*} \\
\end{array}$ \\
\hline Total & 22,753 & 113,929 & 1,550 & 2,904 & 7,195 & 200,451 & 3,977 & 2,725 & 401 \\
\hline California & 1,940 & 9,962 & 139 & 260 & 725 & 19,131 & 424 & 302 & 41 \\
\hline New York & 1,515 & 6,401 & 114 & 214 & 509 & 10,688 & 298 & 213 & 31 \\
\hline Texas & 1,522 & 6,909 & 93 & 175 & 454 & 12,248 & 247 & 172 & 26 \\
\hline Florida & 1,167 & 6,115 & 88 & 165 & 439 & 11,951 & 251 & 176 & 25 \\
\hline Illinois & 991 & 5,784 & 82 & 154 & 427 & 10,571 & 238 & 168 & 23 \\
\hline Pennsylvania & 1,103 & 5,667 & 75 & 140 & 364 & 9,845 & 195 & 137 & 20 \\
\hline Ohio & 951 & 5,203 & 69 & 129 & 294 & 8,979 & 159 & 113 & 16 \\
\hline Michigan & 801 & 4,868 & 64 & 119 & 286 & 8,354 & 155 & 16 & 16 \\
\hline Massachusetts & 601 & 2,970 & 56 & 104 & 263 & 5,364 & 155 & 112 & 15 \\
\hline New Jersey & 778 & 3,595 & 57 & 107 & 259 & 6,095 & 150 & 108 & 15 \\
\hline Virginia & 602 & 3,381 & 50 & 94 & 236 & 5,914 & 130 & 93 & 12 \\
\hline Minnesota & 467 & 3,225 & 41 & 77 & 207 & 5,870 & 112 & 79 & 11 \\
\hline Georgia & 663 & 2,909 & 40 & 75 & 198 & 5,495 & 113 & 80 & 11 \\
\hline Maryland & 365 & 2,588 & 40 & 74 & 196 & 4,905 & 115 & 83 & 11 \\
\hline Missouri & 515 & 2,541 & 35 & 65 & 169 & 4,558 & 89 & 62 & 9 \\
\hline Indiana & 572 & 3,336 & 39 & 72 & 166 & 5,477 & 84 & 59 & 9 \\
\hline North Carolina & 682 & 2,816 & 37 & 69 & 160 & 4,947 & 87 & 62 & 9 \\
\hline Tennessee & 526 & 2,244 & 30 & 57 & 137 & 3,910 & 73 & 51 & 8 \\
\hline Wisconsin & 465 & 2,777 & 30 & 56 & 129 & 4,634 & 66 & 47 & 7 \\
\hline Colorado & 357 & 1,778 & 24 & 45 & 126 & 3,283 & 70 & 49 & 7 \\
\hline Connecticut & 277 & 1,578 & 25 & 47 & 114 & 2,604 & 66 & 47 & 7 \\
\hline Washington & 419 & 2,011 & 26 & 49 & 113 & 3,320 & 61 & 43 & 6 \\
\hline Arizona & 251 & 1,559 & 19 & 36 & 89 & 2,923 & 51 & 36 & 5 \\
\hline Kentucky & 386 & 1,798 & 23 & 42 & 87 & 2,832 & 44 & 31 & 5 \\
\hline Louisiana & 343 & 1,544 & 19 & 35 & 79 & 2,700 & 42 & 30 & 4 \\
\hline Alabama & 404 & 1,608 & 19 & 35 & 75 & 2,610 & 38 & 27 & 4 \\
\hline Oklahoma & 350 & 1,536 & 17 & 31 & 74 & 2,670 & 38 & 26 & 4 \\
\hline Oregon & 245 & 1,273 & 14 & 27 & 66 & 2,249 & 36 & 25 & 4 \\
\hline South Carolina & 350 & 1,354 & 16 & 30 & 63 & 2,244 & 33 & 22 & 4 \\
\hline Iowa & 307 & 1,604 & 15 & 29 & 60 & 2,582 & 30 & 21 & 3 \\
\hline Arkansas & 314 & 1,282 & 15 & 28 & 59 & 2,014 & 28 & 20 & 3 \\
\hline Kansas & 273 & 1,246 & 13 & 24 & 57 & 2,085 & 29 & 20 & 3 \\
\hline New Hampshire & 140 & 788 & 11 & 21 & 50 & 1,353 & 27 & 19 & 3 \\
\hline Mississippi & 290 & 1,126 & 13 & 24 & 48 & 1,826 & 24 & 17 & 3 \\
\hline Hawaii & 107 & 623 & 9 & 17 & 41 & 1,153 & 24 & 17 & 2 \\
\hline Nebraska & 181 & 820 & 9 & 17 & 39 & 1,426 & 20 & 15 & 2 \\
\hline Utah & 143 & 681 & 8 & 15 & 39 & 1,347 & 21 & 15 & 2 \\
\hline Nevada & 118 & 565 & 8 & 16 & 35 & 932 & 20 & 14 & 2 \\
\hline West Virginia & 212 & 898 & 10 & 19 & 35 & 1,316 & 17 & 12 & 2 \\
\hline Maine & 150 & 615 & 8 & 14 & 30 & 995 & 15 & 11 & 2 \\
\hline Delaware & 69 & 465 & 7 & 14 & 28 & 716 & 15 & 11 & 2 \\
\hline New Mexico & 124 & 569 & 6 & 12 & 26 & 1,039 & 14 & 10 & 1 \\
\hline Rhode Island & 113 & 502 & 7 & 13 & 26 & 752 & 14 & 10 & 1 \\
\hline Montana & 108 & 546 & 6 & 11 & 22 & 861 & 11 & 8 & 1 \\
\hline Idaho & 116 & 560 & 5 & 9 & 21 & 950 & 10 & 7 & 1 \\
\hline Vermont & 76 & 360 & 5 & 9 & 20 & 609 & 10 & 7 & 1 \\
\hline Wyoming & 64 & 360 & 5 & 9 & 18 & 552 & 9 & 6 & 1 \\
\hline South Dakota & 101 & 398 & 4 & 7 & 15 & 647 & 7 & 5 & 1 \\
\hline North Dakota & 84 & 351 & 4 & 7 & 13 & 552 & 6 & 5 & 1 \\
\hline Alaska & 53 & 241 & 3 & 6 & 12 & 376 & 6 & 5 & 1 \\
\hline
\end{tabular}

* Values expressed in 2004 dollars (GDP Implicit Price Deflator, US Dept. Commerce). 
Table 6-8. Economic Impacts of the U.S. Retail Food and Beverage Stores Sector by State, 2002

\begin{tabular}{|c|c|c|c|c|c|c|c|c|c|}
\hline State & $\begin{array}{l}\text { Establish- } \\
\text { ments }\end{array}$ & $\begin{array}{c}\text { Employ- } \\
\text { ment } \\
\text { (jobs) }\end{array}$ & $\begin{array}{l}\text { Annual } \\
\text { Wages } \\
(\$ M n)^{*}\end{array}$ & $\begin{array}{c}\text { Output } \\
\text { Gross } \\
\text { Margin on } \\
\text { Sales } \\
(\$ \mathrm{Mn})^{*} \\
\end{array}$ & $\begin{array}{l}\text { Output } \\
\text { Impacts } \\
(\$ M n)^{*}\end{array}$ & $\begin{array}{l}\text { Employm } \\
\text { ent } \\
\text { Impacts } \\
\text { (jobs) }\end{array}$ & $\begin{array}{l}\text { Value } \\
\text { Added } \\
\text { Impacts } \\
(\$ M n)^{*}\end{array}$ & $\begin{array}{l}\text { Labor } \\
\text { Income } \\
\text { Impacts } \\
(\$ M n)^{*}\end{array}$ & $\begin{array}{c}\text { Indirect } \\
\text { Business } \\
\text { Tax } \\
\text { Impacts } \\
(\$ M n)^{*}\end{array}$ \\
\hline Total & 22,465 & 19,222 & 343 & 917 & 2,263 & 35,117 & 1,385 & 944 & 156 \\
\hline California & 2,428 & 1,972 & 48 & 129 & 355 & 4,195 & 226 & 159 & 25 \\
\hline Texas & 1,408 & 1,282 & 23 & 61 & 157 & 2,374 & 94 & 65 & 11 \\
\hline Florida & 1,268 & 1,333 & 22 & 58 & 153 & 2,477 & 92 & 64 & 10 \\
\hline New York & 2,297 & 1,304 & 23 & 61 & 142 & 2,113 & 89 & 62 & 10 \\
\hline Pennsylvania & 1,024 & 980 & 15 & 41 & 105 & 1,776 & 63 & 43 & 7 \\
\hline New Jersey & 1,027 & 721 & 15 & 39 & 93 & 1,247 & 58 & 41 & 7 \\
\hline Illinois & 921 & 645 & 11 & 30 & 82 & 1,217 & 50 & 35 & 5 \\
\hline Ohio & 881 & 815 & 13 & 35 & 78 & 1,389 & 46 & 32 & 5 \\
\hline Massachusetts & 671 & 597 & 11 & 30 & 74 & 1,046 & 46 & 33 & 5 \\
\hline Georgia & 608 & 623 & 10 & 26 & 67 & 1,156 & 41 & 28 & 5 \\
\hline Michigan & 878 & 610 & 10 & 27 & 63 & 1,062 & 38 & 4 & 4 \\
\hline Arizona & 260 & 389 & 9 & 24 & 60 & 785 & 38 & 26 & 4 \\
\hline Maryland & 502 & 402 & 9 & 23 & 60 & 817 & 39 & 27 & 4 \\
\hline Virginia & 514 & 481 & 8 & 23 & 57 & 879 & 35 & 25 & 4 \\
\hline North Carolina & 581 & 534 & 8 & 23 & 52 & 921 & 31 & 22 & 4 \\
\hline Washington & 423 & 390 & 9 & 23 & 52 & 720 & 33 & 23 & 4 \\
\hline Colorado & 337 & 296 & 7 & 19 & 51 & 636 & 32 & 23 & 4 \\
\hline Minnesota & 384 & 377 & 6 & 16 & 43 & 742 & 26 & 18 & 3 \\
\hline Missouri & 348 & 331 & 6 & 15 & 37 & 619 & 22 & 15 & 2 \\
\hline Connecticut & 316 & 285 & 6 & 15 & 35 & 497 & 23 & 16 & 3 \\
\hline Wisconsin & 343 & 386 & 6 & 15 & 35 & 654 & 20 & 14 & 2 \\
\hline Indiana & 396 & 363 & 5 & 14 & 33 & 627 & 19 & 13 & 2 \\
\hline Tennessee & 402 & 349 & 5 & 14 & 33 & 636 & 20 & 13 & 2 \\
\hline Oregon & 294 & 243 & 5 & 12 & 29 & 460 & 18 & 13 & 2 \\
\hline Alabama & 310 & 267 & 4 & 11 & 24 & 457 & 14 & 10 & 2 \\
\hline Louisiana & 361 & 282 & 4 & 11 & 24 & 497 & 14 & 10 & 2 \\
\hline South Carolina & 297 & 280 & 4 & 11 & 23 & 479 & 14 & 9 & 2 \\
\hline Kentucky & 305 & 270 & 4 & 10 & 21 & 430 & 12 & 8 & 1 \\
\hline Iowa & 177 & 245 & 4 & 9 & 20 & 407 & 12 & 8 & 1 \\
\hline Nevada & 115 & 129 & 3 & 8 & 18 & 236 & 11 & 8 & 1 \\
\hline Utah & 97 & 152 & 2 & 7 & 18 & 310 & 10 & 7 & 1 \\
\hline Kansas & 210 & 186 & 3 & 7 & 17 & 327 & 10 & 7 & 1 \\
\hline Oklahoma & 248 & 171 & 2 & 7 & 15 & 318 & 9 & 6 & 1 \\
\hline New Hampshire & 113 & 134 & 2 & 6 & 13 & 231 & 8 & 6 & 1 \\
\hline Arkansas & 205 & 142 & 2 & 5 & 11 & 233 & 6 & 4 & 1 \\
\hline Maine & 145 & 125 & 2 & 5 & 11 & 218 & 7 & 5 & 1 \\
\hline Mississippi & 228 & 153 & 2 & 6 & 11 & 252 & 7 & 5 & 1 \\
\hline Nebraska & 140 & 134 & 2 & 5 & 11 & 236 & 7 & 5 & 1 \\
\hline Hawaii & 105 & 81 & 2 & 4 & 10 & 155 & 7 & 5 & 1 \\
\hline New Mexico & 95 & 91 & 2 & 5 & 10 & 173 & 6 & 4 & 1 \\
\hline Idaho & 83 & 80 & 1 & 4 & 8 & 154 & 5 & 4 & 1 \\
\hline Rhode Island & 107 & 77 & 1 & 4 & 7 & 121 & 5 & 3 & 1 \\
\hline West Virginia & 132 & 119 & 1 & 4 & 7 & 183 & 4 & 3 & 1 \\
\hline Delaware & 87 & 62 & 1 & 3 & 6 & 99 & 4 & 3 & 0 \\
\hline Montana & 77 & 61 & 1 & 3 & 6 & 105 & 3 & 2 & 0 \\
\hline Vermont & 80 & 69 & 1 & 3 & 6 & 125 & 4 & 3 & 0 \\
\hline Alaska & 56 & 47 & 1 & 3 & 5 & 80 & 3 & 2 & 0 \\
\hline South Dakota & 77 & 69 & 1 & 3 & 5 & 112 & 3 & 2 & 0 \\
\hline North Dakota & 60 & 49 & 1 & 2 & 3 & 76 & 2 & 1 & 0 \\
\hline Wyoming & 44 & 37 & 1 & 2 & 3 & 60 & 2 & 1 & 0 \\
\hline
\end{tabular}


Table 6-9. Economic Impacts of the U.S. Retail General Merchandise Stores Sector by State, 2002

\begin{tabular}{|c|c|c|c|c|c|c|c|c|c|}
\hline State & $\begin{array}{c}\text { Establish- } \\
\text { ments }\end{array}$ & $\begin{array}{c}\text { Employ- } \\
\text { ment } \\
\text { (jobs) }\end{array}$ & $\begin{array}{l}\text { Annual } \\
\text { Wages } \\
(\$ M n)^{*}\end{array}$ & $\begin{array}{c}\text { Output } \\
\text { Gross } \\
\text { Margin } \\
\text { on Sales } \\
(\$ M n)^{*}\end{array}$ & $\begin{array}{l}\text { Output } \\
\text { Impacts } \\
(\$ M n)^{*}\end{array}$ & $\begin{array}{l}\text { Employ- } \\
\text { ment } \\
\text { Impacts } \\
\text { (jobs) }\end{array}$ & $\begin{array}{l}\text { Value } \\
\text { Added } \\
\text { Impacts } \\
\text { (\$Mn)* }\end{array}$ & $\begin{array}{l}\text { Labor } \\
\text { Income } \\
\text { Impacts } \\
(\$ M n)^{*}\end{array}$ & $\begin{array}{c}\text { Indirect } \\
\text { Business } \\
\text { Tax } \\
\text { Impacts } \\
(\$ M n)^{*}\end{array}$ \\
\hline Total & 22,710 & 56,651 & 993 & 2,544 & 6,150 & 93,443 & 3,973 & 2,639 & 448 \\
\hline California & 1,406 & 4,851 & 96 & 245 & 665 & 8,484 & 437 & 303 & 47 \\
\hline Texas & 1,857 & 4,425 & 79 & 203 & 517 & 7,675 & 332 & 226 & 38 \\
\hline Florida & 1,237 & 3,326 & 60 & 154 & 399 & 5,870 & 259 & 177 & 29 \\
\hline Illinois & 872 & 2,411 & 40 & 103 & 278 & 3,986 & 177 & 122 & 19 \\
\hline New York & 1,290 & 2,457 & 45 & 116 & 265 & 3,721 & 177 & 122 & 20 \\
\hline Michigan & 841 & 2,503 & 43 & 110 & 258 & 3,893 & 164 & 19 & 19 \\
\hline Pennsylvania & 1,043 & 2,349 & 38 & 96 & 242 & 3,816 & 154 & 105 & 17 \\
\hline Ohio & 1,024 & 2,536 & 42 & 107 & 237 & 3,953 & 150 & 103 & 17 \\
\hline Georgia & 880 & 1,783 & 31 & 79 & 204 & 3,045 & 133 & 91 & 15 \\
\hline Missouri & 558 & 1,529 & 29 & 74 & 186 & 2,618 & 118 & 81 & 13 \\
\hline Virginia & 678 & 1,573 & 27 & 70 & 174 & 2,612 & 115 & 80 & 12 \\
\hline North Carolina & 921 & 1,723 & 28 & 71 & 165 & 2,818 & 106 & 73 & 12 \\
\hline Indiana & 576 & 1,635 & 26 & 67 & 152 & 2,524 & 95 & 64 & 11 \\
\hline Tennessee & 661 & 1,399 & 23 & 60 & 142 & 2,373 & 91 & 62 & 11 \\
\hline Washington & 302 & 1,145 & 24 & 62 & 140 & 1,885 & 92 & 63 & 11 \\
\hline Minnesota & 331 & 1,150 & 20 & 51 & 134 & 1,972 & 85 & 59 & 10 \\
\hline New Jersey & 543 & 1,213 & 22 & 56 & 131 & 1,925 & 87 & 61 & 10 \\
\hline Colorado & 235 & 888 & 17 & 43 & 117 & 1,571 & 76 & 52 & 8 \\
\hline Arizona & 305 & 997 & 18 & 47 & 114 & 1,700 & 74 & 51 & 8 \\
\hline Wisconsin & 391 & 1,209 & 19 & 49 & 112 & 1,883 & 70 & 48 & 8 \\
\hline Maryland & 366 & 1,014 & 16 & 41 & 107 & 1,744 & 72 & 50 & 7 \\
\hline Massachusetts & 313 & 884 & 16 & 42 & 102 & 1,453 & 68 & 47 & 7 \\
\hline Louisiana & 486 & 1,088 & 18 & 45 & 100 & 1,746 & 64 & 44 & 7 \\
\hline Oregon & 226 & 830 & 17 & 43 & 100 & 1,435 & 66 & 45 & 8 \\
\hline Alabama & 604 & 1,063 & 18 & 46 & 98 & 1,722 & 63 & 43 & 7 \\
\hline Kentucky & 490 & 1,042 & 17 & 44 & 90 & 1,571 & 57 & 39 & 7 \\
\hline Oklahoma & 412 & 890 & 14 & 37 & 88 & 1,579 & 56 & 38 & 6 \\
\hline South Carolina & 477 & 857 & 14 & 37 & 78 & 1,329 & 50 & 33 & 6 \\
\hline Arkansas & 385 & 763 & 12 & 32 & 66 & 1,167 & 41 & 28 & 5 \\
\hline Mississippi & 451 & 748 & 12 & 32 & 65 & 1,145 & 41 & 28 & 5 \\
\hline Kansas & 276 & 661 & 11 & 27 & 63 & 1,076 & 40 & 27 & 5 \\
\hline Iowa & 309 & 689 & 11 & 29 & 62 & 1,059 & 39 & 27 & 5 \\
\hline Utah & 135 & 484 & 9 & 22 & 57 & 885 & 37 & 25 & 4 \\
\hline Connecticut & 186 & 527 & 9 & 23 & 54 & 822 & 36 & 25 & 4 \\
\hline Nevada & 103 & 422 & 8 & 22 & 48 & 679 & 32 & 22 & 4 \\
\hline New Mexico & 141 & 402 & 7 & 18 & 41 & 676 & 27 & 19 & 3 \\
\hline Nebraska & 180 & 402 & 6 & 16 & 37 & 639 & 23 & 16 & 3 \\
\hline New Hampshire & 137 & 327 & 6 & 15 & 35 & 532 & 22 & 16 & 3 \\
\hline West Virginia & 247 & 431 & 7 & 17 & 32 & 620 & 20 & 14 & 3 \\
\hline Hawaii & 63 & 249 & 5 & 13 & 31 & 456 & 21 & 15 & 2 \\
\hline Idaho & 111 & 297 & 5 & 13 & 29 & 502 & 19 & 13 & 2 \\
\hline Maine & 148 & 246 & 4 & 11 & 23 & 391 & 15 & 10 & 2 \\
\hline Alaska & 70 & 186 & 4 & 10 & 21 & 297 & 14 & 10 & 2 \\
\hline Delaware & 79 & 217 & 4 & 10 & 19 & 320 & 13 & 9 & 1 \\
\hline Montana & 76 & 192 & 4 & 9 & 18 & 301 & 12 & 8 & 1 \\
\hline South Dakota & 75 & 165 & 3 & 7 & 14 & 255 & 9 & 6 & 1 \\
\hline Rhode Island & 59 & 140 & 2 & 6 & 12 & 209 & 8 & 6 & 1 \\
\hline North Dakota & 50 & 153 & 2 & 6 & 11 & 225 & 7 & 5 & 1 \\
\hline Wyoming & 41 & 112 & 2 & 5 & 9 & 166 & 6 & 4 & 1 \\
\hline Vermont & 64 & 73 & 1 & 3 & 6 & 119 & 4 & 3 & 0 \\
\hline
\end{tabular}

\footnotetext{
* Values expressed in 2004 dollars (GDP Implicit Price Deflator, US Dept. Commerce).
} 


\section{Economic Impacts of Urban Forestry}

In the aforementioned S290 national nursery industry survey, seventeen plant categories were used to determine the distribution of nursery sales by growers in 2003. Four of these pertained to trees including deciduous shade trees, evergreen trees, Christmas trees, and fruit trees. Of the total product mix portfolio of nurseries in the U.S., these four categories represented 26.8 percent of total nursery sales. The top deciduous shade tree producing states, in terms of the share of their respective states nursery sales, included Kentucky ( $44 \%$ of total nursery sales), New Mexico (43\%), Colorado (37\%), Tennessee (32\%), South Dakota (32\%), Indiana (31\%), Iowa (31\%), and Minnesota (31\%). he top evergreen tree producing states, in terms of the share of their respective states nursery sales, included North Dakota (30\% of total nursery sales), Indiana (28\%), Ohio (27\%), Minnesota (22\%), Arkansas (21\%), and Montana (21\%). The states with the highest relative percentage of Christmas trees and fruit trees included West Virginia (44\%) and Tennessee (18\%), respectively.

In 1997, the American Nursery \& Landscape Association (ANLA) and the U.S.D.A. Forest Service teamed up to conduct a landmark study of landscape tree planting in the U.S. The objectives of the ongoing survey were to measure the progress of Community Forestry activities, to provide a database for planning; to confirm the availability of adequate tree supplies; and to help plan and track future care and maintenance efforts. The research study included a survey of the largest private nurseries in the U.S. as identified by the American Nursery \& Landscape Association. Utilizing a representative sample of 1,872 nurseries and obtaining a response of 40 percent (749 respondents) provided results that have a margin of error plus or minus four percent. The survey determined that 122,268,000 landscape trees were shipped during 1995-96. That was a 5.1 percent increase over 1994-95 and the fourth year-in-a row that total tree shipments had increased. Tree shipments totaled $116 \mathrm{Mn}$ in 1994-95; $111 \mathrm{Mn} 1993-94 ; 104 \mathrm{Mn}$ in 1992-93, $98 \mathrm{Mn}$ in 1991-92, and $104 \mathrm{Mn}$ in 1990-91. From 1991 to 1996 total tree shipments increased at an average annual rate of 3.3 percent. Of all trees shipped in 1995-96, 43.5 percent $(53,144,000)$ were evergreens, 27.9 percent $(34,132,000)$ were shade trees, 20.9 percent $(25,519,000)$ were flowering trees, and 7.7 percent $(9,472,000)$ were fruit/nut trees. From 1995 to 1996 shipments of evergreen trees increased by 8.3 percent, or 4,085,000 trees; shade trees by 3.2 percent, or 1,066,000 trees; flowering trees by 4.3 percent, or 1,056,000 trees; and fruit/nut trees decreased by 2.3 percent, or 222,000 trees. From 1991 to 1996 shipments of evergreen trees increased at an average annual rate of 6.4 percent; shade trees increased at an average annual rate of 1.3 percent; flowering trees increased at an average annual rate of 0.4 percent; and fruit/nut trees increased at an average annual rate of 3.6 percent.

Regionally, the West produced 32.2 percent of all trees in 1995-96, the South 30.8 percent, the Midwest 28.2 percent, and the East 8.8 percent. States that shipped the most trees in 1995-96 included Oregon (14.9\% of total tree shipments), Michigan (13.9\%), California (13.3\%), Tennessee (7.9\%) and Florida (7.1\%). These five states accounted for 57.1 percent of all trees shipped in 1995-96. Of all trees shipped in 1995-96, landscape contractors purchased 31.9 percent, retail garden centers 27.1 percent, re-wholesalers 20.4 percent, general merchandisers 14 percent, municipalities 4.5 percent, and other customers 2.1 percent. Total landscape tree production was projected to increase 42.7 percent, with production projected to grow by an estimated 16.6 percent from 1996 to 1997, and 22.4 percent from 1997 to 1998 . No other tree planting surveys have been cited in the literature since this landmark study conducted by ANLA. However, assuming that the previously mentioned benchmarks hold [that approximately 26.8 percent of nursery sales are trees that could be used in urban forestry settings and that 4.5 percent of the trees produced by nurseries are sold to municipalities] then several inferences can be drawn when coupled with the Green Industry primary and secondary data included herein.

\section{Economic Impacts of Tree Sales and Tree Care Services}

Economic impacts of the portion of urban forestry related to commercial tree production and tree care services are summarized in Table 7-1. The estimates are based on tree production by the nursery and greenhouse sector, and tree care by the landscaping services sector. The total value of tree production suitable for urban forestry, including deciduous, evergreen, fruit, and Christmas trees, was $\$ 4.63 \mathrm{Bn}$. This value represented 27.2 percent of total output by the nursery and greenhouse sector for the U.S. as a whole, but for individual states ranged from as high as 82 percent (Mississippi) to less than one percent (Hawaii). The value of tree care services was $\$ 9.92 \mathrm{Bn}$, which represented 27.1 percent of the output of the landscaping services sector. The total output of tree 
production and care services was valued at $\$ 14.55 \mathrm{Bn}$. This translated into $\$ 21.02 \mathrm{Bn}$ in total output impacts, 259,224 jobs, $\$ 14.12 \mathrm{Bn}$ in value added, $\$ 9.93 \mathrm{Bn}$ in labor income, and $\$ 516 \mathrm{Mn}$ in indirect business tax impacts.

Table 7-1. Economic Impacts of U.S. Urban Forestry Tree Sales and Tree Care Services, 2002

\begin{tabular}{|c|c|c|c|c|c|c|c|c|c|}
\hline State & $\begin{array}{c}\text { Nursery \& } \\
\text { Greenhouse } \\
\text { Sector Tree } \\
\text { Sales } \\
(\$ M n)^{*} \\
\end{array}$ & $\begin{array}{c}\text { Urban } \\
\text { Forestry } \\
\text { Tree Sales } \\
(\%)\end{array}$ & $\begin{array}{c}\text { Landscaping } \\
\text { Services } \\
\text { Tree Care } \\
\text { Output } \\
(\$ M n)^{*} \\
\end{array}$ & $\begin{array}{l}\text { Total Tree } \\
\text { Sales and } \\
\text { Services } \\
\text { Output } \\
(\$ M n)^{*} \\
\end{array}$ & $\begin{array}{l}\text { Output } \\
\text { Impacts } \\
(\$ M n)^{*}\end{array}$ & $\begin{array}{l}\text { Employ- } \\
\text { ment } \\
\text { Impacts } \\
\text { (jobs) }\end{array}$ & $\begin{array}{l}\text { Value } \\
\text { Added } \\
\text { Impacts } \\
(\$ M n)^{*}\end{array}$ & $\begin{array}{l}\text { Labor } \\
\text { Income } \\
\text { Impacts } \\
(\$ M n)^{*}\end{array}$ & $\begin{array}{c}\text { Indirect } \\
\text { Business } \\
\text { Tax } \\
\text { Impacts } \\
(\$ M n)^{*} \\
\end{array}$ \\
\hline Alabama & 71.2 & 27.2 & 109 & 180 & 281 & 3,905 & 203 & 125 & 8 \\
\hline Alaska & 3.6 & 27.2 & 11 & 15 & 17 & 147 & 11 & 9 & 0 \\
\hline Arizona & 80.5 & 27.2 & 233 & 313 & 539 & 7,243 & 370 & 268 & 16 \\
\hline Arkansas & 20.7 & 42.4 & 45 & 66 & 96 & 1,387 & 66 & 45 & 2 \\
\hline California & 642.6 & 18.8 & 1,482 & 2,125 & 3,077 & 37,769 & 2,105 & 1,549 & 75 \\
\hline Colorado & 149.9 & 55.1 & 245 & 395 & 540 & 5,504 & 351 & 259 & 12 \\
\hline Connecticut & 14.9 & 5.8 & 193 & 208 & 319 & 3,172 & 222 & 172 & 9 \\
\hline Delaware & 21.3 & 61.5 & 34 & 55 & 90 & 1,045 & 65 & 41 & 2 \\
\hline Florida & 335.3 & 17.5 & 698 & 1,033 & 1,553 & 21,946 & 1,122 & 768 & 42 \\
\hline Georgia & 44.6 & 13.6 & 324 & 369 & 527 & 7,198 & 368 & 274 & 13 \\
\hline Hawaii & 0.3 & 0.3 & 43 & 43 & 75 & 1,101 & 51 & 40 & 2 \\
\hline Idaho & 19.4 & 28.1 & 43 & 62 & 95 & 1,179 & 68 & 49 & 2 \\
\hline Illinois & 117.4 & 31.5 & 508 & 626 & 845 & 7,519 & 568 & 436 & 19 \\
\hline Indiana & 121.8 & 62.4 & 208 & 330 & 469 & 5,197 & 290 & 209 & 11 \\
\hline Iowa & 33.9 & 42.0 & 63 & 97 & 127 & 1,396 & 76 & 56 & 3 \\
\hline Kansas & 16.3 & 27.2 & 72 & 88 & 133 & 1,673 & 82 & 63 & 3 \\
\hline Kentucky & 53.1 & 53.1 & 70 & 123 & 166 & 2,468 & 121 & 79 & 4 \\
\hline Louisiana & 15.1 & 16.6 & 59 & 74 & 91 & 1,478 & 59 & 45 & 2 \\
\hline Maine & 14.4 & 36.9 & 37 & 52 & 81 & 1,048 & 54 & 40 & 2 \\
\hline Maryland & 90.0 & 27.2 & 285 & 375 & 629 & 7,407 & 445 & 321 & 17 \\
\hline Massachusetts & 39.0 & 24.4 & 290 & 329 & 470 & 4,798 & 317 & 252 & 11 \\
\hline Michigan & 174.0 & 26.6 & 339 & 513 & 664 & 6,613 & 414 & 13 & 13 \\
\hline Minnesota & 136.5 & 58.4 & 152 & 289 & 418 & 3,748 & 246 & 177 & 10 \\
\hline Mississippi & 40.2 & 81.7 & 31 & 71 & 91 & 1,346 & 71 & 41 & 2 \\
\hline Missouri & 17.9 & 17.0 & 167 & 185 & 207 & 2,893 & 135 & 110 & 3 \\
\hline Montana & 13.6 & 38.6 & 13 & 26 & 39 & 425 & 23 & 16 & 1 \\
\hline Nebraska & 16.1 & 45.3 & 43 & 59 & 72 & 782 & 43 & 34 & 1 \\
\hline Nevada & 4.7 & 44.9 & 140 & 144 & 249 & 3,314 & 171 & 133 & 7 \\
\hline New Hampshire & 1.4 & 2.4 & 51 & 53 & 83 & 962 & 54 & 43 & 2 \\
\hline New Jersey & 89.6 & 24.1 & 383 & 472 & 672 & 7,599 & 470 & 352 & 17 \\
\hline New Mexico & 31.3 & 49.9 & 37 & 68 & 93 & 1,171 & 68 & 48 & 2 \\
\hline New York & 59.8 & 16.7 & 424 & 484 & 547 & 5,408 & 392 & 316 & 10 \\
\hline North Carolina & 206.2 & 21.1 & 279 & 486 & 834 & 10,119 & 602 & 367 & 25 \\
\hline North Dakota & 4.5 & 39.2 & 7 & 11 & 15 & 166 & 8 & 6 & 0 \\
\hline Ohio & 313.4 & 53.5 & 445 & 758 & 1,013 & 12,331 & 633 & 451 & 19 \\
\hline Oklahoma & 46.8 & 20.2 & 74 & 121 & 169 & 2,961 & 103 & 74 & 4 \\
\hline Oregon & 343.8 & 40.9 & 119 & 462 & 856 & 11,107 & 537 & 376 & 24 \\
\hline Pennsylvania & 227.5 & 29.8 & 406 & 633 & 910 & 10,427 & 621 & 450 & 22 \\
\hline Rhode Island & 5.4 & 13.7 & 35 & 40 & 70 & 773 & 46 & 35 & 2 \\
\hline South Carolina & 40.9 & 12.2 & 135 & 176 & 307 & 4,592 & 212 & 128 & 9 \\
\hline South Dakota & 8.1 & 42.6 & 9 & 17 & 21 & 222 & 12 & 8 & 0 \\
\hline Tennessee & 162.2 & 55.1 & 160 & 323 & 548 & 9,408 & 329 & 226 & 15 \\
\hline Texas & 207.1 & 14.4 & 601 & 808 & 1,188 & 16,438 & 757 & 564 & 30 \\
\hline Utah & 26.3 & 21.2 & 52 & 78 & 116 & 1,482 & 80 & 58 & 3 \\
\hline Vermont & 7.5 & 31.8 & 20 & 27 & 41 & 440 & 27 & 20 & 1 \\
\hline Virginia & 72.7 & 31.9 & 320 & 393 & 595 & 8,282 & 396 & 300 & 15 \\
\hline Washington & 149.4 & 36.6 & 205 & 355 & 527 & 6,264 & 374 & 271 & 13 \\
\hline West Virginia & 16.1 & 57.5 & 31 & 47 & 61 & 1,232 & 32 & 25 & 1 \\
\hline Wisconsin & 66.4 & 27.2 & 177 & 243 & 374 & 3,938 & 236 & 178 & 9 \\
\hline Wyoming & 2.4 & 36.4 & 12 & 15 & 20 & 202 & 12 & 10 & 0 \\
\hline Total All States & $4,631.2$ & 27.2 & 9,919 & 14,550 & 21,020 & 259,224 & 14,120 & 9,931 & 516 \\
\hline
\end{tabular}

See next page for notes to table. 
* Values expressed in 2004 dollars (GDP Implicit Price Deflator).

Note: Missing values for some states were estimated at national average. Percentage of landscape services for tree care: $27.05 \%$. Sources: Census of Agriculture or ERS Floriculture \& Nursery Outlook (nursery output); National Nursery Survey, 2004 (percentage of nursery output for trees); 2002 Economic Census (share of landscape services for tree care).

In the leading states of California and Florida, tree production represented 19 and 18 percent, respectively, of total nursery and greenhouse output. For California, output impacts of urban forestry were in excess of $\$ 3 \mathrm{Bn}$, employment impacts were 37,769 jobs, and value added impacts were $\$ 2.11 \mathrm{Bn}$, while in Florida, output impacts were $\$ 1.55 \mathrm{Bn}$, employment impacts were 21,946 jobs, and value added impacts were $\$ 1.12 \mathrm{Bn}$. Other states with large value added impacts for urban forestry included Texas ( $\$ 757 \mathrm{Mn})$, Ohio (\$633 Mn), Pennsylvania (\$621 Mn), North Carolina (\$602 Mn), Illinois (\$568 Mn), Oregon (\$537 Mn), New Jersey (\$470 Mn) and Maryland (\$445 Mn).

\section{Other Economic Benefits of Urban Forestry}

In addition to these impacts on nursery production and landscape services, trees and landscaping have important effects on residential and commercial property values. Most of the studies reported in the literature have evaluated variation in sales prices for properties in relation to a variety of influencing variables, such as location, building size, neighborhood features, transportation access, etc. These investigations are generally known among professional economists as "hedonic pricing" or "revealed preference" studies. Typically, the studies are conducted within a limited geographic area to control for dominating variables such as income or demographic composition. Payne (1973), who was one of the first researchers in this area, reported a 7 percent premium on average for the market value of a single-family residence due to the presence of "arborescent vegetation" (trees). The premium ranged from 5 to 15 percent. However, there was a ceiling on the positive effect of trees; beyond more than about 30 trees on a residential lot or more than 67 percent wooded cover, values were reduced. A study conducted in Manchester, CT found that good tree cover increased sale prices for homes by 6 to 9 percent (Morales, Boyce and Favretti, 1976). Also, Siela and Anderson (1982) reported that new homes on tree-planted lots commanded 7 percent higher prices than bare lots.

A study of 800 single-family home sales during 1978-80 in Athens GA concluded that the presence of trees in the front yard added 3 to 5 percent to the sales price (Anderson and Cordell, 1985). In a second study by the same authors in a lower-priced neighborhood also found a 3.5 to 4.5 percent premium in sales value for homes with intermediate to large trees (Anderson and Cordell, 1988). It was further reported that each evergreen or broadleaved tree contributes about $\$ 319$ to $\$ 376$, respectively, in value to the home. In a study of 269 single-family house sales with an average price of $\$ 93,272$, it was found that the presence of mature trees contributed about 2 percent to the home value (Dombrow, Rodriguez and Sirmans, 2000). A study by Henry in 1999 estimated the contribution of the quality of landscaping to house prices for a sample of 218 home sales in Greenville, SC from 1996 to 1997. For homes with the same square footage and other house characteristics, selling prices were six to seven percent higher if landscaping was judged excellent rather than good. The price premium obtained by upgrading landscaping from average to good was approximately four to five percent. Finally, in perhaps the most sophisticated investigation of its kind to date, DeRosiers, Therialut, Kestens and Villeneuve (2002) examined 760 single-family home sales in Quebec, Canada, between 1993 and 2000. It was found that a positive differential of tree cover between a property and its immediate neighborhood raised the property value by about 0.2 percent for each percentage point difference. The higher the proportion of retired people in the neighborhood, the more beneficial was the presence of trees, while it was less so for neighborhoods with a predominance of people aged 45-64. For small homes (bungalows and cottages), a high percentage of ground covers and landscape features such as flower beds contributed more value than did a tree canopy. This investigation also found that an excessive tree cover may negatively impact values, consistent with earlier studies.

Well-maintained trees also increase the "curb appeal" of properties. Research comparing sales prices of residential properties with different tree resources suggests that people are willing to pay 3 to 7 percent more for properties with tree resources versus few or no trees. One of the most comprehensive studies of the influence of trees on residential property values was based on actual sales prices and found that each large front-yard tree was 
associated with about a 1 percent increase in home sales prices (Anderson and Cordell 1988). A much greater value of 9 percent $(\$ 15,000)$ was determined in a U.S. Tax Court case for the loss of a large black oak on a property valued at $\$ 164,500$ (Neely 1988). Depending on average home sales prices, the value of this benefit can contribute significantly to cities' property tax revenues.

A study was conducted in 1999 regarding consumer perspectives on the value of the components in a "good" landscape and which attributes of a landscape that consumers valued most (Hardy et al. 2000). Using conjoint design, 1323 volunteer participants in seven states viewed 16 photographs that depicted the front of a landscaped residence. Landscapes were constructed using various levels of three attributes: plant material type, design sophistication, and plant size. Results showed that the relative importance increased from plant material type to plant size to design sophistication. Across all seven markets, study participants perceived that home value increased from $5 \%$ to $11 \%$ for homes with a good landscape.

Trees sold to municipalities for use in urban forest settings (e.g. parks and other recreational areas) have other economic and environmental benefits beyond those mentioned above. Once they have been installed into the urban landscape, they can result in substantial energy savings; reduction of atmospheric carbon dioxide; improved air quality; reduction of stormwater runoff and hydrology; and enhanced aesthetic benefits.

Street trees modify climate and conserve building energy use in three principal ways: (1) through shading that reduces the amount of radiant energy absorbed and stored by built surfaces; (2) through transpiration that converts moisture to water vapor and thus cools by using solar energy that would otherwise result in heating of the air; and (3) through wind speed reduction that reduces the infiltration of outside air into interior spaces and conductive heat loss where thermal conductivity is relatively high such as glass windows (Simpson 1998). Buildings and pavement, along with little canopy and/or soil cover, increase the ambient temperatures within a city. Research shows that even in moderated climates, temperatures in urban centers are steadily increasing by approximately $0.5^{\circ} \mathrm{F}$ per decade. Winter benefits of this warming do not compensate for the detrimental effects of magnifying summertime temperatures. Because electric demand of cities increases about 1 to 2 percent per $1^{\circ} \mathrm{F}$ increase in temperature, approximately 3 to 8 percent of current electric demand for cooling is used to compensate for this urban heat island effect of the last four decades (Akbari et al. 1992). Warmer temperatures in cities, compared to surrounding rural areas, have other implications. Increases in $\mathrm{CO} 2$ emissions from fossil fuel power plants, municipal water demand, unhealthy ozone levels, and human discomfort and disease are all symptoms associated with urban heat islands. In many areas, there are opportunities to ameliorate these problems through strategic tree planting and stewardship of existing trees allowing for streetscapes that reduce stormwater runoff, conserve energy and water, sequester $\mathrm{CO} 2$, attract wildlife, and provide other aesthetic, social, and economic benefits through urban renewal developments.

Tree spacing, crown spread, and vertical distribution of leaf area influence the transport of cool air and pollutants along streets and out of urban canyons. For individual buildings, street trees can increase energy efficiency in the summer and winter, depending on placement. Solar angles are important when the summer sun is low in the east and west for several hours each day. Tree shade to protect east and west walls help keep buildings cool. In the winter, solar access on the southern side of buildings can warm interior spaces. Rates at which outside air infiltrates a building can increase substantially with wind speed. In cold, windy weather, the entire volume of air in a poorly sealed home may change two to three times per hour. Even in newer or tightly sealed homes, the entire volume of air may change every two to three hours. Trees can reduce wind speed and resulting air infiltration by up to 50 percent, translating into potential annual heating savings of 25 percent (Heisler 1986). Reductions in wind speed reduce heat transfer through conductive materials as well. Cool winter winds, blowing against singlepane windows, can contribute significantly to the heating load of homes and buildings by increasing the temperature gradient between inside and outside temperatures. Trees reduce air infiltration and conductive heat loss from buildings.

Urban forests can also reduce atmospheric carbon dioxide (CO2) in the environment. Trees directly sequester $\mathrm{CO} 2$ as woody and foliar biomass while trees grow and trees near buildings can reduce the demand for heating and air conditioning, thereby reducing emissions associated with electric power production. On the other hand, vehicles, chain saws, chippers, and other equipment release CO2 during the process of planting and maintaining trees. And eventually, all trees die and most of the $\mathrm{CO} 2$ that has accumulated in their woody biomass is released 
into the atmosphere through decomposition. The combustion of gasoline and diesel fuels by vehicle fleets, and equipment such as chainsaws, chippers, stump removers, and leaf blowers is a relatively minor source of CO2. Typically, $\mathrm{CO} 2$ released due to tree planting, maintenance, and other program-related activities is about 2 to 8 percent of annual CO2 reductions obtained through sequestration and avoided power plant emissions (McPherson and Simpson 1999).

Urban trees also provide air quality benefits. They absorb gaseous pollutants (e.g., ozone, nitrogen oxides, and sulfur dioxide) through leaf surfaces; intercept particulate matter (e.g., dust, ash, pollen, and smoke); reduce emissions from power generation by limiting building energy consumption; release oxygen through photosynthesis; and transpire water and shade surfaces, which lowers local air temperatures, thereby reducing ozone levels. In the absence of the cooling effects of trees, higher air temperatures contribute to ozone formation. Most trees emit various biogenic volatile organic compounds (BVOC) such as isoprenes and monoterpenes that can contribute to ozone formation. The ozone-forming potential of different tree species varies considerably. A computer simulation study for the Los Angeles basin found that increased tree planting of low BVOC emitting tree species would reduce ozone concentrations and exposure to ozone, while planting of medium- and highemitters would increase overall ozone concentrations (Taha 1996).

Studies that have simulated urban forest effects on stormwater report annual runoff reductions of 2 to 7 percent. Annual interception of rainfall by Sacramento's urban forest for the urbanized area was only about 2 percent due to the winter rainfall pattern and predominance of non-evergreen species (Xiao et al. 1998). However, average interception on land with tree canopy cover ranged from 6 to 13 percent (150 gallons per tree on average), close to values reported for rural forests. In Modesto, California, each street and park tree was estimated to reduce stormwater runoff by 845 gallons annually, with a benefit valued at $\$ 7$ per tree (McPherson et al. 1999b). A typical medium-sized tree in coastal southern California was estimated to intercept 2,380 gallons (\$5) annually (McPherson et al. 2000). These studies showed that broadleaf evergreens and conifers intercept more rainfall than deciduous species where winter rainfall patterns prevail.

Trees provide a host of aesthetic, social, economic, and health advantages that should be included in any benefitcost analysis. One of the most frequently cited reasons that people plant trees is for beautification. Trees add color, texture, line, and form to the landscape. In this way, trees soften the hard geometry that dominates built environments. Research on the aesthetic quality of residential streets has shown that street trees are the single strongest positive influence on scenic quality (Schroeder and Cannon 1983). Consumer surveys have found that preference ratings increase with the presence of trees in the commercial streetscape. In contrast to areas without trees, shoppers indicated that they shop more often and longer in well-landscaped business districts, and were willing to pay more for goods and services (Wolf 1999). Research in public housing complexes found that outdoor spaces with trees were used significantly more often than spaces without trees. By facilitating interactions among residents, trees can contribute to reduced levels of domestic violence, as well as foster safer and more sociable neighborhood environments (Sullivan and Kuo 1996). Scientific studies confirm our intuition that trees in cities provide social and psychological benefits. Humans derive substantial pleasure from trees, whether it is inspiration from their beauty, a spiritual connection, or a sense of meaning (Dwyer et al. 1992; Lewis 1996). Following natural disasters, people often report a sense of loss if the urban forest in their community has been damaged (Hull 1992).

Views of trees and nature from homes and offices provide restorative experiences that ease mental fatigue and help people to concentrate (Kaplan \& Kaplan 1989). Desk-workers with a view of nature report lower rates of sickness and greater satisfaction with their jobs compared to those having no visual connection to nature (Kaplan 1992). Trees provide important settings for recreation and relaxation in and near cities. The act of planting trees can have social value, for community bonds between people and local groups often result. The presence of trees in cities provides public health benefits and improves the well-being of those who live, work and recreate in cities. Physical and emotional stress has both short term and long-term effects. Prolonged stress can compromise the human immune system. A series of studies on human stress caused by general urban conditions and city driving show that views of nature reduce stress response of both body and mind (Parsons et al. 1998). City nature also appears to have an "immunization effect," in that people show less stress response if they've had a recent view of trees and vegetation. Hospitalized patients with views of nature and time spent outdoors need less medication, sleep better, and have a better outlook than patients without connections to nature (Ulrich 1985). 
Trees reduce exposure to ultraviolet light, thereby lowering the risk of harmful effects from skin cancer and cataracts (Tretheway and Manthe 1999).

Certain environmental benefits from trees are more difficult to quantify than those previously described, but can be just as important. Noise can reach unhealthy levels in cities. Trucks, trains, and planes can produce noise that exceeds 100 decibels, twice the level at which noise becomes a health risk. Thick strips of vegetation in conjunction with landforms or solid barriers can reduce highway noise by 6-15 decibels. Plants absorb more high frequency noise than low frequency, which is advantageous to humans since higher frequencies are most distressing to people (Miller 1997). Although urban forests contain less biological diversity than rural woodlands, numerous types of wildlife inhabit cities and are generally highly valued by residents. For example, older parks, cemeteries, and botanical gardens often contain a rich assemblage of wildlife. Street tree corridors can connect a city to surrounding wetlands, parks, and other greenspace resources that provide habitats that conserve biodiversity (Platt et al. 1994).

Urban forestry also provides jobs for both skilled and unskilled labor. In 2002, there were 262,242 full-time parks and recreation employees across the nation. Public service programs and grassroots-led urban and community forestry programs provide horticultural training to volunteers across the U.S. Also, urban and community forestry provides educational opportunities for residents who want to learn about nature through first-hand experience (McPherson and Mathis 1999). Local nonprofit tree groups, along with municipal volunteer programs, often provide educational materials; work with area schools; and provide hands-on training in the care of trees. 


\section{Literature and Information Sources Cited}

Akbari, H.; Davis, S.; Dorsano, S.; Huang, J.; Winnett, S., eds. 1992. Cooling Our Communities: A Guidebook on Tree Planting and Light-Colored Surfacing. Washington, DC: U.S. Environmental Protection Agency.; 26 p. Alden, H.A. 1995. Hardwoods of North America. USDA Forest Service, FPL General Technical Report No. 83. Madison, WI. 136 p.

Anderson, L.M. and H.K. Cordell. 1988. Influence of trees on residential property values in Athens, Georgia. Landscape and Urban Planning 15:153-64.

Anderson, L.M. and H.K. Cordell. 1988. Residential property values improved by landscaping with trees. Southern Journal of Applied Forestry 9:162-166.

Arizona Agricultural Statistics Service. 2002 Arizona Green Industry Survey. OMB No. 0535-0227. Available at http://www.nass.usda.gov/az.

Bartenstein, F. 1981. The future of urban forestry. J. Arboric. 7(10):261-267.

Borden, Buddy and R.R. Fletcher. Economic Contribution of Nevada's Green Industry Operations on the State of Nevada, 2002. September 2003, UCED 2003/04-13

Bradley, G. 1995.Urban Forest Landscapes: Integrating Multidisciplinary Perspectives. Seattle: Univ. of WA Press.

Brumfield, Robin, Economic and Marketing Issues from a Grower's Perspective, Agricultural Outlook Forum 2003, presented Friday, February 21, 2003.

Butterfield, Bruce, National Gardening Survey 2003, National Gardening Association, Available at http://www.gardenresearch.com.

Campbell, Dr. Gene. The Illinois Green Industry Brochure. College of Agricultural, Consumer and Environmental Sciences. University of Illinois at Urbana-Champaign. Available at http://research.nres.uiuc.edu/report01-01.

Cox, Linda J. An Update on the Economic Role of Hawaii's Landscape Service. Cooperative Extension Service. University of Hawaii, Manoa. Economic Issues January 2003 EI-5. Available at http://www.ctahr.hawaii.edu/oc/freepubs/pdf/EI-5.pdf.

Danekas, Gene, M. Schlegel, M. Brown, C. Mends, and B. Gorman. 2000 Missouri Nursery Survey. Missouri Agricultural Statistics Service. December 2001. Available at http://agebb.missouri.edu/mass/massnursery.pdf.

Des Rosiers, F., M. Theriault, Y. Kestens and P. Villeneuve. 2002. Landscaping and house values: an empirical investigation. Journal of Real Estate Research. 23 (1-2): 139-161.

Dombrow, J., M. Rodriguez and C.F. Sirmans. 2000. The market value of mature trees in single-family housing markets. The Appraisal Journal. 68: 39-43.

Dwyer, J.F., E.G. McPherson, H.W. Schroeder and R.A. Rowntree. 1992. Assessing the benefits and costs of the urban forest. Journal of Arboriculture 18(5):227-234.

Florkowski, W.J. and G. Landry. An Economic Profile of the Professional Turfgrass and Landscape Industry in Georgia. The University of Georgia. Research Report Number 672. December 2000. Available at http://pubs.caes.uga.edu/caespubs/pubs/PDF/RR672.pdf.

Gao, G., J. Smith, and J. Chatfield. 2001 Ohio Green Industry Survey. The Ohio State University Extension. June 2002. Available at http://www.onla.org/FinalReportONLA.pdf.

Green Industry Research Consortium (S-290 Multi-State Research Committee) Fourth National Nursery Industry Survey, www.s290.org.

Hardy, J., B. Behe, S. Barton, T. Page, R. Schutzki, K. Muzii, T. Fernandez, T. Haque, J. Brooker, C. Hall, R. Hinson, P. Knight, R. McNiel, D. Rowe, and C. Safley. "Consumer Preferences for Plant Size, Type of Plant Material and Design Sophistication in Residential Landscaping." Journal of Environmental Horticulture. 184 (December 2000): 224-230

Heisler, G.M. 1986. Energy savings with trees. Journal of Arboriculture. 12(5):113-125.

Henry, Mark S. "Landscape Quality and the Price of Single Family Houses: Further Evidence from Home Sales in Greenville, South Carolina," J. Env. Hort. 17(1):25-30, March 1999.

Hinson, Roger A., R. Pinel, and D.W. Hughes. Louisiana's Green Industry: Evaluation of its Economic Contribution. September 2003. Research Information Sheet \#108. Available at http://www.lsuagcenter.com. 
Hughes, David W. and R.A. Hinson. The Value of the Ornamental Plants and Turfgrass Industries to the Louisiana Economy. D.A.E. Research Series No. 708. February 1997.

Hull, R.B. 1992. How the public values urban forests. J. Arboric. 18(2):98-101.

Jerardo, Alberto, Floriculture and Nursery Crops Outlook, USDA-ERS FLO-03, September 2004, [www.ers.usda.gov/Briefing/floriculture].

Jerardo, Alberto, Floriculture and Nursery Crops Situation and Outlook Yearbook, USDA-ERS FLO2004, June 2004, [www.ers.usda.gov/Briefing/floriculture].

Jull, Dr. Laura G. Economic Impact of Wisconsin's Green Industry. 2002.

Kaplan, R. and S. Kaplan. 1989. The Experience of Nature: A Psychological Perspective. Cambridge University Press, Cambridge, UK.

Lawn \& Landscape Magazine, 2004 State of the Industry Report, October 13, 2004, Available at http://www.lawnandlandscape.com.

Lewis, C.A. 1996. Green Nature/Human Nature: The Meaning of Plants in Our Lives. University of Illinois Press, Chicago, IL.

Maco, S.E. 2003. A practical approach to assessing structure, function, and value of street tree populations in small communities. J. Arboric. 29(2):84-97.

McPherson, E. G. 1984. Planting design for solar control, chapter 8. In Energy Conserving Site Design, Am. Soc. Landscape Archit., Washington, D.C. p.141-164.

McPherson, E. G. 2005. “Trees with Benefits," American Nurseryman, Volume 201, Issue 7, April 1, 2005.

McPherson, E.G. 1993. Evaluating the cost effectiveness of shade trees for demand-side management. The Electricity Journal 6(9): 57-65.

McPherson, E.G. and J.R. Simpson. 1999. Guidelines for Calculating Carbon Dioxide Reductions Trough Urban Forestry Programs. USDA Forest Service, PSW General Technical Report No. 171, Albany, CA.

McPherson, E.G. and J.R. Simpson. 2002. A comparison of municipal forest benefits and costs in Modesto and Santa Monica, California, USA. Urban For. Urban Green. 1(2002):61-74.

McPherson, E.G., J.R. Simpson, P.J. Peper and Q. Xiao. 1999. Benefit-cost analysis of Modesto's municipal urban forest. Journal of Arboriculture. 25(5):235-248.

McPherson, E.G., K.I. Scott and J.R. Simpson. 1998. Estimating cost effectiveness of residential yard trees for improving air quality in Sacramento, California, using existing models. Atmospheric Environment 32(2):7584.

MIG, Inc. Implan 200150 State Data Package. Stillwater, Mn, Jan. 2004.

MIG, Inc. Implan Professional, version 2.0, Social Accounting \& Impact Analysis Software: User's Guide, Analysis Guide and Data Guide. Stillwater, Mn, 418pp., Apr.1999.

Miller, Marvin, Opportunities and Challenges for Floricultural Producers Selling to a Changing Marketplace, Agricultural Outlook Forum 2003, presented Friday, February 21, 2003.

Miller, R.E. and P.D. Blair. Input-output analysis: Foundations and extensions. Prentice-Hall, Englewood Cliffs, NJ, 464pp., 1985.

Morales, D., B.N. Boyce and R.J. Favretti. 1976. The contribution of trees to residential property value: Manchester, Connecticut. Valuation. 23 (2): 26-43.

National Nursery Survey. S-290 Multi-state project USDA/CSREES. Unpublished data analyzed by Alan Hodges, University of Florida, 2005.

Neely, D., ed. 1988. Valuation of Landscape Trees, Shrubs, and Other Plants. Seventh ed. Urbana, IL: International Society of Arboriculture. $50 \mathrm{p}$.

NEWAZ GreenIndBro.qxp. The Economic Impact of Arizona's Green Industry. May 10, 2004. Available at http://www.nass.usda.gov/az.

Orland, Vining \& Ebreo. 1992. The Effect of Street Trees on Perceived Values of Residential Property. Environment and Behavior, 24(3)298-325.

Parsons, R., L.G. Tassinary, R.S. Ulrich, M.R. Hebl and M. Grossman-Alexander. 1998. The view from the road: implications for stress recovery and immunization. Journal of Environmental Psychology 18(2):113-140.

Payne, B.R. 1973. The twenty-nine tree home improvement plan. Natural History. 82: 74-5.

Payne, B.R. and S. Strom. 1975. The contribution of trees to the appraised value of unimproved residential land. Valuation. 22(2): 36-45.

Perry, Dr. Leonard and Dr. N. Hampton. “Minnesota's Nursery and Landscape Industry”. Minnesota Nursery and Landscape Association. 2002 Minnesota Nursery and Landscape Industry Economic Impact Study. 
Platt, R.H., R.A Rowntree and P.C. Muick, eds. 1994. The Ecological City. Boston, MA, University of Massachusetts. 292 p.

Rathwell, P. James, M.G. Evatt, and M.S. Henry. Contributions of the Ornamental Horticulture and Turfgrass Industry to the South Carolina Economy, 1999, EER 194, Department of Agricultural and Applied Economics, Clemson University, April 2001.

Schroeder, H.W. and W.N. Cannon. 1983. The esthetic contribution of trees to residential streets in Ohio towns. Journal of Arboriculture. 9: 237-243.

Scott, K.I., E.G. McPherson, and J.R. Simpson. 1998. Air pollutant uptake by Sacramento's urban forest. Journal of Arboriculture 24(4):224-234.

Simpson, J.R. 1998. Urban forest impacts on regional space conditioning energy use: Sacramento County case study. Journal of Arboriculture 24(4): 201-214.

Sullivan, W.C. and E.E. Kuo. 1996. Do trees strengthen urban communities, reduce domestic violence? Arborist News. 5(2):33-34.

Taha, H. 1996. Modeling impacts of increased urban vegetation on odistrict air quality in the South Coast Air Basin. Atmospheric Environment 30: 3423-3430.

Templeton, Scott R., and G. Goldman. Estimating Economic Activity and Impacts of Urban Forestry in California with Multiple Data Sources from the Early 1990s. International Society of Arboriculture. Volume 22, No. 3. May 1996. Available at http://www.isa-arbor.com/publications/ joaAbstracts/joamay96.html.

Thilmany, Dawn. The Economic Contribution of Colorado's Green Industry-Phase I: Allied Industry and SectorSpecific Revenue and Employment Trends. Department of Agricultural and Resource Economics. Colorado State University.

Tretheway, R. and A. Manthe. 1999. Skin cancer prevention: another good reason to plant trees. In McPherson, E.G. and Mathis, S. Proceedings of the Best of the West Summit. University of California, Davis, CA.

U.S. Census Bureau. Annual Estimates of the Population for the United States and States, and for Puerto Rico. April 1, 2000 to July 1, 2004 (NST-EST2004-01). Population Division, December 22, 2004.

U.S. Census Bureau. 2002 County Business Patterns, EPCD, County \& State Database on NAICS Basis. United States Department of Commerce, Washington, D.C.. Available at http://www.census.gov/epcd/cbp/view/cbpview.html, accessed Dec. 2004.

U.S. Census Bureau. Annual Benchmark Report for Retail Trade and Food Services: January 1992 through February 2004. Current Business Reports BR/03-A. U.S. Department of Commerce, Washington, D.C., Mar. 2004.

U.S. Census Bureau. Annual Benchmark Report for Wholesale Trade: January 1992 through December 2003. Current Business Reports BW/03-A. U.S. Department of Commerce, Washington, D.C., Mar. 2004.

U.S. Census Bureau. Architectural, Engineering and Related Services, 2002 Economic Census, Professional, Scientific and Technical Services Industry Series, EC02-541-03. United States Department of Commerce, Washington, D.C., Oct. 2004.

U.S. Census Bureau. Building Material and Supplies Dealers, 2002 Economic Census, Retail Trade Industry Series, EC02-441-18. United States Department of Commerce, Washington, D.C., Nov. 2004.

U.S. Census Bureau. Farm, Floral and Nursery Supplies, 2002 Economic Census, Wholesale Trade Industry Series, EC02-421-15. United States Department of Commerce, Washington, D.C., Nov. 2004.

U.S. Census Bureau. Florists, 2002 Economic Census, Retail Trade Industry Series, EC02-441-16. United States Department of Commerce, Washington, D.C., Aug. 2004.

U.S. Census Bureau. Food and Beverage Stores, 2002 Economic Census, Retail Trade Industry Series, EC02441-07. United States Department of Commerce, Washington, D.C., Sep. 2004.

U.S. Census Bureau. General Merchandise Stores, 2002 Economic Census, Retail Trade Industry Series, EC02441-11. United States Department of Commerce, Washington, D.C., Oct. 2004.

U.S. Census Bureau. Lawn and Garden Equipment \& Supplies Stores, 2002 Economic Census, Retail Trade Industry Series, EC02-441-08. United States Department of Commerce, Washington, D.C., Sep. 2004.

U.S. Census Bureau. Lawn and Garden Tractor and Home Lawn and Garden Equipment Manufacturing, 2002 Economic Census, Manufacturing Industry Series, EC02-311-333112 (RV). United States Department of Commerce, Washington, D.C., Dec. 2004.

U.S. Census Bureau. Machinery, Equipment and Supplies, 2002 Economic Census, Wholesale Trade Industry Series, EC02-421-09. United States Department of Commerce, Washington, D.C., Sep. 2004. 
U.S. Census Bureau. Prefabricated Metal Building and Component Manufacturing, 2002 Economic Census, Manufacturing Industry Series, EC02-311-332311 (RV). United States Department of Commerce, Washington, D.C., Jan. 2005.

U.S. Census Bureau. Services to Buildings and Dwellings, 2002 Economic Census, Administrative and Support and Waste Management and Remedial Services Industry Series, EC02-561-07. United States Department of Commerce, Washington, D.C., June 2004.

U.S. Department of Agriculture, National Agricultural Statistics Service. 2002 Census of Agriculture. United States Summary and State Data, Vol. 1, Geographic Area Series, Part 51, AC-02-A-51. United States Department of Agriculture, Washington, D.C., June 2004.

U.S. Department of Agriculture, National Agricultural Statistics Service, Floriculture Crops 2003 Summary, April 2004, Available at http://www.nass.usda.gov.

U.S. Department of Agriculture, National Agricultural Statistics Service, Nursery Crops 2003 Summary, July 2004, Available at http://www.nass.usda.gov.

U.S. Department of Commerce. Gross Domestic Product: Implicit Price Deflator, 1970-2004, Annual. Available at http://research.stlouisfed.org/fred/data/gdp/gdpdef.

U.S. Department of Commerce. Gross Domestic Product Implicit Price Deflators (quarterly). Bureau of Economic Analysis, Washington, D.C. Dec. 22, 2004. Available at http://research.stlouisfed.org/fred/data/gdp/gdpdef.

U.S. Landscape Tree Planting Survey, American Nursery \& Landscape Association and the USDA Forest Service, conducted by the National Gardening Association. Available at http://www.anla.org/pdffiles/survey.pdf, retrieved January 2004.

Ulrich, R. S. 1985. Human responses to vegetation and landscapes. Landscape and Urban Planning 13: 29-44.

University of Illinois at Urbana-Champaign. The Illinois Green Industry. Department of Natural Resources and Environmental Sciences. Available at http://research.nres.uiuc.edu/report01-01/toc.html.

University of Vermont and the University of Maine. The Connecticut Green Industry \& The Connecticut Economy. February 2003. Available at http://www.flowersplantsinct.com/pdf/EconomicImpact.pdf.

Watson, Phillip, S. Davies, and D. Thilmany. The Economic and Environmental Aspects of Colorado's Golf Industry.

Willits, Fern K. and M. Shields. Pennsylvania's Green Industry: Its Nature and Contribution to the State's Economy. Department of Agricultural Economics and Rural Sociology, Pennsylvania State University, University Park, PA, 2001.

Wisniewski, Nicole. Nevada Green Industry Contributes $\$ 1.3$ billion to the State's Economy. Lawn and Landscape, 7/30/2004. Available at http://www.lawnandlandscape.com/News/news.asp? Id=2560.

Wolf, K.L. 1999. Nature and commerce: human ecology in business districts. In C. Kollin (Ed), Building Cities of Green: Proceedings of the 1999 National Urban Forest Conference. Washington, D.C. American Forests; 56-59.

Wray, P.H. and D.R. Prestemon. 1983. Assessment of street trees in Iowa's small communities. Iowa State Journal of Research. 58(2):261-268.

Wulfhorst, Dr. J.D. and J. Nelson. The Green Industry of Idaho. Social Science Research Unit, University of Idaho, July 2001.

Xiao, Q., E.G. McPherson, J.R. Simpson and S.L Ustin. 1998. Rainfall interception by Sacramento's urban forest. Journal of Arboriculture. 


\section{Appendix A--Economic Multipliers for the U.S. Green Industry Sectors}

Appendix Table A-1. Multipliers for the Nursery and Greenhouse Sector

\begin{tabular}{|c|c|c|c|c|c|c|c|c|c|}
\hline \multirow[t]{2}{*}{ State } & \multicolumn{3}{|c|}{$\begin{array}{l}\text { Output (dollars per dollar } \\
\text { output) }\end{array}$} & \multicolumn{3}{|c|}{$\begin{array}{l}\text { Employment (jobs per million } \\
\text { dollars output) }\end{array}$} & \multicolumn{3}{|c|}{$\begin{array}{l}\text { Value Added (dollars per dollar } \\
\text { output) }\end{array}$} \\
\hline & Direct & Indirect & Induced & Direct & Indirect & Induced & Direct & Indirect & Induced \\
\hline Alabama & 1.0000 & 0.0138 & 0.9627 & 10.0716 & 0.1517 & 12.4493 & 0.9806 & 0.0087 & 0.5680 \\
\hline Alaska & 1.0000 & 0.2405 & 0.6367 & 6.9822 & 2.2494 & 7.9460 & 0.5387 & 0.1286 & 0.4360 \\
\hline Arizona & 1.0000 & 0.0887 & 1.1240 & 4.7669 & 1.1851 & 13.2398 & 0.8576 & 0.0523 & 0.6795 \\
\hline Arkansas & 1.0000 & 0.0686 & 0.8536 & 8.8633 & 0.8414 & 11.8816 & 0.9002 & 0.0357 & 0.4852 \\
\hline California & 1.0000 & 0.2452 & 1.2352 & 7.6564 & 2.5024 & 12.3251 & 0.7122 & 0.1381 & 0.7684 \\
\hline Colorado & 1.0000 & 0.2781 & 1.1559 & 5.1514 & 2.8823 & 12.7265 & 0.6105 & 0.1587 & 0.7082 \\
\hline Connecticut & 1.0000 & 0.0123 & 0.9990 & 11.9537 & 0.1086 & 9.8177 & 0.9806 & 0.0082 & 0.6279 \\
\hline Delaware & 1.0000 & 0.0107 & 0.8625 & 5.2486 & 0.1031 & 9.5756 & 0.9806 & 0.0058 & 0.4777 \\
\hline Florida & 1.0000 & 0.0506 & 1.3196 & 11.0630 & 0.6775 & 15.6132 & 0.9340 & 0.0326 & 0.8040 \\
\hline Georgia & 1.0000 & 0.0138 & 1.2438 & 6.7008 & 0.1384 & 13.9947 & 0.9806 & 0.0085 & 0.7596 \\
\hline Hawaii & 1.0000 & 0.0461 & 1.2567 & 15.2817 & 0.5506 & 16.0437 & 0.9262 & 0.0283 & 0.8468 \\
\hline Idaho & 1.0000 & 0.0121 & 1.0397 & 5.8911 & 0.1811 & 15.0342 & 0.9806 & 0.0073 & 0.6278 \\
\hline Illinois & 1.0000 & 0.2825 & 1.1046 & 5.5685 & 2.2010 & 11.4449 & 0.6263 & 0.1513 & 0.6655 \\
\hline Indiana & 1.0000 & 0.2931 & 0.7993 & 6.9067 & 2.8990 & 9.6792 & 0.5697 & 0.1482 & 0.4550 \\
\hline Iowa & 1.0000 & 0.3099 & 0.6446 & 4.3094 & 3.5665 & 8.5764 & 0.4743 & 0.1629 & 0.3721 \\
\hline Kansas & 1.0000 & 0.4025 & 0.7166 & 4.3825 & 3.8081 & 9.1713 & 0.4222 & 0.1964 & 0.4150 \\
\hline Kentucky & 1.0000 & 0.0590 & 0.8568 & 15.7775 & 0.7674 & 10.8581 & 0.9111 & 0.0324 & 0.4945 \\
\hline Louisiana & 1.0000 & 0.1925 & 0.8690 & 11.2600 & 2.0092 & 11.7970 & 0.6971 & 0.1000 & 0.5193 \\
\hline Maine & 1.0000 & 0.1089 & 0.9014 & 12.5596 & 1.5805 & 12.6316 & 0.7853 & 0.0638 & 0.5372 \\
\hline Maryland & 1.0000 & 0.0556 & 1.3375 & 8.6240 & 0.5121 & 15.0707 & 0.9042 & 0.0358 & 0.8800 \\
\hline Massachusetts & 1.0000 & 0.2388 & 0.9664 & 19.7582 & 2.2071 & 9.7408 & 0.6108 & 0.1449 & 0.6075 \\
\hline Michigan & 1.0000 & 0.3241 & 0.8163 & 9.3898 & 3.2341 & 8.9356 & 0.5090 & 0.1811 & 0.4717 \\
\hline Minnesota & 1.0000 & 0.3785 & 0.9383 & 5.3138 & 3.4583 & 10.6843 & 0.4687 & 0.2027 & 0.5559 \\
\hline Mississippi & 1.0000 & 0.0140 & 0.8944 & 12.0558 & 0.1667 & 12.7023 & 0.9806 & 0.0074 & 0.5274 \\
\hline Missouri & 1.0000 & 0.3312 & 0.9235 & 11.9260 & 3.9309 & 11.4019 & 0.5243 & 0.1858 & 0.5467 \\
\hline Montana & 1.0000 & 0.2274 & 0.6610 & 5.8150 & 2.6883 & 9.9243 & 0.5392 & 0.1098 & 0.3944 \\
\hline Nebraska & 1.0000 & 0.2772 & 0.7011 & 3.0697 & 3.0804 & 9.3944 & 0.4488 & 0.1491 & 0.4114 \\
\hline Nevada & 1.0000 & 0.0091 & 1.1471 & 6.7480 & 0.1111 & 12.6026 & 0.9806 & 0.0054 & 0.7101 \\
\hline New Hampshire & 1.0000 & 0.2508 & 0.8996 & 17.4168 & 2.9685 & 10.4967 & 0.6143 & 0.1508 & 0.5304 \\
\hline New Jersey & 1.0000 & 0.1144 & 0.8814 & 14.6176 & 0.9297 & 8.5973 & 0.8390 & 0.0667 & 0.5537 \\
\hline New Mexico & 1.0000 & 0.0641 & 1.0139 & 5.4760 & 0.8715 & 14.3807 & 0.9031 & 0.0337 & 0.6365 \\
\hline New York & 1.0000 & 0.1471 & 0.8323 & 8.4013 & 1.1874 & 8.2927 & 0.7335 & 0.0879 & 0.5313 \\
\hline North Carolina & 1.0000 & 0.0135 & 1.0810 & 5.0395 & 0.1432 & 13.1926 & 0.9806 & 0.0086 & 0.6360 \\
\hline North Dakota & 1.0000 & 0.2983 & 0.4694 & 3.7344 & 2.9328 & 6.9018 & 0.3862 & 0.1378 & 0.2775 \\
\hline Ohio & 1.0000 & 0.2732 & 0.7432 & 10.3194 & 2.7486 & 8.8566 & 0.5800 & 0.1412 & 0.4321 \\
\hline Oklahoma & 1.0000 & 0.3647 & 0.9112 & 12.8865 & 4.7810 & 12.2900 & 0.5553 & 0.1878 & 0.5383 \\
\hline Oregon & 1.0000 & 0.3294 & 0.9778 & 13.8836 & 4.2927 & 12.2179 & 0.6255 & 0.1961 & 0.5969 \\
\hline Pennsylvania & 1.0000 & 0.1821 & 1.1103 & 10.6688 & 1.6047 & 12.2233 & 0.7525 & 0.1004 & 0.6635 \\
\hline Rhode Island & 1.0000 & 0.1877 & 0.6967 & 15.3068 & 2.0839 & 8.4742 & 0.6193 & 0.1073 & 0.4414 \\
\hline South Carolina & 1.0000 & 0.0127 & 0.9736 & 10.8809 & 0.1444 & 12.6953 & 0.9806 & 0.0083 & 0.5816 \\
\hline South Dakota & 1.0000 & 0.2270 & 0.6427 & 3.3676 & 2.5886 & 9.2002 & 0.5031 & 0.1226 & 0.3712 \\
\hline Tennessee & 1.0000 & 0.3834 & 0.9055 & 27.1515 & 5.4979 & 10.7726 & 0.5292 & 0.2087 & 0.5297 \\
\hline Texas & 1.0000 & 0.3805 & 1.1091 & 11.9364 & 3.7715 & 12.0449 & 0.5917 & 0.2066 & 0.6634 \\
\hline Utah & 1.0000 & 0.0957 & 1.3284 & 9.4921 & 1.0876 & 17.5553 & 0.8639 & 0.0523 & 0.7882 \\
\hline Vermont & 1.0000 & 0.1314 & 0.8535 & 7.6434 & 1.8912 & 11.9415 & 0.7577 & 0.0764 & 0.5149 \\
\hline Virginia & 1.0000 & 0.1930 & 1.0200 & 15.3364 & 2.0653 & 11.8871 & 0.6868 & 0.1130 & 0.6547 \\
\hline Washington & 1.0000 & 0.1196 & 1.0418 & 10.8278 & 1.3185 & 11.5996 & 0.8467 & 0.0689 & 0.6358 \\
\hline West Virginia & 1.0000 & 0.5103 & 0.4108 & 34.0957 & 7.9856 & 5.9567 & 0.2380 & 0.2247 & 0.2502 \\
\hline Wisconsin & 1.0000 & 0.2804 & 0.8099 & 7.2554 & 3.0855 & 10.0009 & 0.5565 & 0.1514 & 0.4698 \\
\hline Wyoming & 1.0000 & 0.2662 & 0.6148 & 5.2722 & 3.1226 & 8.8150 & 0.5680 & 0.1310 & 0.3745 \\
\hline
\end{tabular}

Source: Implan 50 state data package, 2001 (MIG, Inc. 2004) 
Appendix Table A-2. Multipliers for the Lawn and Garden Equipment Manufacturing Sector

\begin{tabular}{|c|c|c|c|c|c|c|c|c|c|}
\hline \multirow[b]{2}{*}{ State } & \multicolumn{3}{|c|}{$\begin{array}{c}\text { Output (dollars per dollar } \\
\text { output) }\end{array}$} & \multicolumn{3}{|c|}{$\begin{array}{c}\text { Employment (jobs per million } \\
\text { dollars output) }\end{array}$} & \multicolumn{3}{|c|}{$\begin{array}{l}\text { Value Added (dollars per } \\
\text { dollar output) }\end{array}$} \\
\hline & Direct & Indirect & Induced & Direct & Indirect & Induced & Direct & Indirect & Induced \\
\hline Alabama & 1.0000 & 0.4429 & 0.4896 & 3.2900 & 3.2506 & 6.4473 & 0.2642 & 0.1947 & 0.2955 \\
\hline Alaska & 0.0000 & 0.0000 & 0.0000 & 0.0000 & 0.0000 & 0.0000 & 0.0000 & 0.0000 & 0.0000 \\
\hline Arizona & 1.0000 & 0.3597 & 0.5697 & 3.3277 & 2.9147 & 6.8604 & 0.2575 & 0.1948 & 0.3502 \\
\hline Arkansas & 1.0000 & 0.4077 & 0.3606 & 3.7138 & 3.4109 & 5.1010 & 0.1886 & 0.1809 & 0.2091 \\
\hline California & 1.0000 & 0.4251 & 0.7547 & 3.2247 & 3.0416 & 7.6171 & 0.2758 & 0.2348 & 0.4736 \\
\hline Colorado & 1.0000 & 0.4800 & 0.7424 & 3.4502 & 3.2811 & 8.2543 & 0.2356 & 0.2564 & 0.4580 \\
\hline Connecticut & 0.0000 & 0.0000 & 0.0000 & 0.0000 & 0.0000 & 0.0000 & 0.0000 & 0.0000 & 0.0000 \\
\hline Delaware & 0.0000 & 0.0000 & 0.0000 & 0.0000 & 0.0000 & 0.0000 & 0.0000 & 0.0000 & 0.0000 \\
\hline Florida & 1.0000 & 0.4004 & 0.6010 & 3.6538 & 3.3020 & 7.2125 & 0.1993 & 0.2208 & 0.3723 \\
\hline Georgia & 1.0000 & 0.4893 & 0.6673 & 3.4603 & 3.4373 & 7.6435 & 0.2338 & 0.2472 & 0.4158 \\
\hline Hawaii & 0.0000 & 0.0000 & 0.0000 & 0.0000 & 0.0000 & 0.0000 & 0.0000 & 0.0000 & 0.0000 \\
\hline Idaho & 0.0000 & 0.0000 & 0.0000 & 0.0000 & 0.0000 & 0.0000 & 0.0000 & 0.0000 & 0.0000 \\
\hline Illinois & 1.0000 & 0.5983 & 0.8371 & 3.2753 & 3.7211 & 8.7408 & 0.2668 & 0.3064 & 0.5073 \\
\hline Indiana & 1.0000 & 0.5382 & 0.5580 & 3.3915 & 3.6417 & 6.8133 & 0.2461 & 0.2472 & 0.3202 \\
\hline Iowa & 1.0000 & 0.4463 & 0.4566 & 3.4311 & 3.4737 & 6.1325 & 0.2390 & 0.2057 & 0.2657 \\
\hline Kansas & 1.0000 & 0.3559 & 0.5204 & 3.1962 & 2.8828 & 6.6860 & 0.2809 & 0.1789 & 0.3016 \\
\hline Kentucky & 1.0000 & 0.4535 & 0.4209 & 3.4025 & 3.3179 & 5.4188 & 0.2441 & 0.1994 & 0.2467 \\
\hline Louisiana & 1.0000 & 0.2969 & 0.4392 & 3.3948 & 2.5738 & 6.0465 & 0.2455 & 0.1518 & 0.2653 \\
\hline Maine & 1.0000 & 0.2612 & 0.4107 & 3.4019 & 2.4644 & 5.8353 & 0.2442 & 0.1391 & 0.2480 \\
\hline Maryland & 1.0000 & 0.3996 & 0.7288 & 3.1810 & 2.6701 & 8.3104 & 0.2836 & 0.2056 & 0.4839 \\
\hline Massachusetts & 1.0000 & 0.4179 & 0.6047 & 3.3937 & 2.7618 & 6.1291 & 0.2457 & 0.2363 & 0.3823 \\
\hline Michigan & 1.0000 & 0.3944 & 0.6655 & 2.6073 & 2.5040 & 7.2272 & 0.3859 & 0.1968 & 0.3826 \\
\hline Minnesota & 1.0000 & 0.4012 & 0.6899 & 3.2360 & 3.0586 & 7.8939 & 0.2738 & 0.2220 & 0.4103 \\
\hline Mississippi & 1.0000 & 0.4277 & 0.3940 & 3.4747 & 3.2135 & 5.6533 & 0.2313 & 0.1739 & 0.2351 \\
\hline Missouri & 1.0000 & 0.5442 & 0.6373 & 3.5221 & 4.0671 & 7.9353 & 0.2228 & 0.2629 & 0.3796 \\
\hline Montana & 0.0000 & 0.0000 & 0.0000 & 0.0000 & 0.0000 & 0.0000 & 0.0000 & 0.0000 & 0.0000 \\
\hline Nebraska & 1.0000 & 0.3542 & 0.5503 & 3.1243 & 3.0915 & 7.4316 & 0.2937 & 0.1776 & 0.3248 \\
\hline Nevada & 0.0000 & 0.0000 & 0.0000 & 0.0000 & 0.0000 & 0.0000 & 0.0000 & 0.0000 & 0.0000 \\
\hline New Hampshire & 0.0000 & 0.0000 & 0.0000 & 0.0000 & 0.0000 & 0.0000 & 0.0000 & 0.0000 & 0.0000 \\
\hline New Jersey & 1.0000 & 0.3708 & 0.5236 & 3.1466 & 2.5061 & 5.1978 & 0.2898 & 0.2142 & 0.3335 \\
\hline New Mexico & 0.0000 & 0.0000 & 0.0000 & 0.0000 & 0.0000 & 0.0000 & 0.0000 & 0.0000 & 0.0000 \\
\hline New York & 1.0000 & 0.5104 & 0.5425 & 3.3149 & 3.0810 & 5.4801 & 0.2597 & 0.2684 & 0.3495 \\
\hline North Carolina & 1.0000 & 0.4225 & 0.6117 & 3.0507 & 3.0719 & 7.6010 & 0.3069 & 0.2013 & 0.3690 \\
\hline North Dakota & 1.0000 & 0.2540 & 0.3334 & 3.3571 & 2.4401 & 4.9355 & 0.2522 & 0.1223 & 0.1981 \\
\hline Ohio & 1.0000 & 0.3979 & 0.4646 & 3.2626 & 2.8137 & 5.5520 & 0.2691 & 0.1792 & 0.2709 \\
\hline Oklahoma & 1.0000 & 0.4274 & 0.5572 & 3.2947 & 3.3980 & 7.5753 & 0.2633 & 0.1922 & 0.3315 \\
\hline Oregon & 1.0000 & 0.4077 & 0.5265 & 3.4647 & 3.3702 & 6.6304 & 0.2330 & 0.2249 & 0.3235 \\
\hline Pennsylvania & 1.0000 & 0.4578 & 0.7085 & 3.0258 & 3.2440 & 7.8619 & 0.3113 & 0.2328 & 0.4260 \\
\hline Rhode Island & 0.0000 & 0.0000 & 0.0000 & 0.0000 & 0.0000 & 0.0000 & 0.0000 & 0.0000 & 0.0000 \\
\hline South Carolina & 1.0000 & 0.4208 & 0.4503 & 3.4422 & 3.1352 & 5.9891 & 0.2370 & 0.1870 & 0.2751 \\
\hline South Dakota & 1.0000 & 0.3119 & 0.4856 & 2.9975 & 2.7494 & 7.0347 & 0.3164 & 0.1506 & 0.2833 \\
\hline Tennessee & 1.0000 & 0.4867 & 0.6024 & 3.3143 & 3.6011 & 7.2425 & 0.2599 & 0.2271 & 0.3550 \\
\hline Texas & 1.0000 & 0.4963 & 0.6462 & 3.6373 & 3.4635 & 7.0829 & 0.2023 & 0.2581 & 0.3891 \\
\hline Utah & 1.0000 & 0.4710 & 0.7295 & 3.2165 & 3.8439 & 9.7837 & 0.2773 & 0.2235 & 0.4385 \\
\hline Vermont & 1.0000 & 0.2966 & 0.4488 & 3.1097 & 2.5556 & 6.3516 & 0.2963 & 0.1454 & 0.2732 \\
\hline Virginia & 1.0000 & 0.3582 & 0.5705 & 3.3473 & 2.6930 & 6.7013 & 0.2540 & 0.1853 & 0.3681 \\
\hline Washington & 1.0000 & 0.2971 & 0.4987 & 3.1437 & 2.3815 & 5.6182 & 0.2903 & 0.1682 & 0.3069 \\
\hline West Virginia & 0.0000 & 0.0000 & 0.0000 & 0.0000 & 0.0000 & 0.0000 & 0.0000 & 0.0000 & 0.0000 \\
\hline Wisconsin & 1.0000 & 0.4608 & 0.6226 & 2.8894 & 3.3055 & 7.7071 & 0.3356 & 0.2180 & 0.3622 \\
\hline Wyoming & 0.0000 & 0.0000 & 0.0000 & 0.0000 & 0.0000 & 0.0000 & 0.0000 & 0.0000 & 0.0000 \\
\hline
\end{tabular}

Source: Implan 50 state data package, 2001 (MIG, Inc. 2004) 
Appendix Table A-3. Multipliers for the Landscaping Services Sector

\begin{tabular}{|c|c|c|c|c|c|c|c|c|c|}
\hline \multirow[b]{2}{*}{ State } & \multicolumn{3}{|c|}{$\begin{array}{l}\text { Output (dollars per dollar } \\
\text { output) }\end{array}$} & \multicolumn{3}{|c|}{$\begin{array}{c}\text { Employment (jobs per million } \\
\text { dollars output) }\end{array}$} & \multicolumn{3}{|c|}{$\begin{array}{l}\text { Value Added (dollars per } \\
\text { dollar output) }\end{array}$} \\
\hline & Direct & Indirect & Induced & Direct & Indirect & Induced & Direct & Indirect & Induced \\
\hline Alabama & 1.000 & 0.247 & 0.939 & 36.6 & 3.7 & 12.3 & 0.665 & 0.159 & 0.567 \\
\hline Alaska & 1.000 & 0.198 & 0.793 & 33.6 & 2.8 & 9.8 & 0.679 & 0.120 & 0.535 \\
\hline Arizona & 1.000 & 0.233 & 1.135 & 30.3 & 3.1 & 13.6 & 0.695 & 0.150 & 0.701 \\
\hline Arkansas & 1.000 & 0.212 & 0.839 & 35.3 & 3.4 & 11.7 & 0.671 & 0.122 & 0.486 \\
\hline California & 1.000 & 0.273 & 1.414 & 27.2 & 3.1 & 14.3 & 0.710 & 0.175 & 0.887 \\
\hline Colorado & 1.000 & 0.257 & 1.356 & 31.0 & 3.2 & 15.1 & 0.691 & 0.164 & 0.840 \\
\hline Connecticut & 1.000 & 0.248 & 1.041 & 27.9 & 2.9 & 10.5 & 0.706 & 0.169 & 0.666 \\
\hline Delaware & 1.000 & 0.200 & 0.820 & 33.3 & 2.8 & 9.7 & 0.681 & 0.124 & 0.486 \\
\hline Florida & 1.000 & 0.272 & 1.299 & 30.0 & 3.7 & 15.4 & 0.696 & 0.182 & 0.804 \\
\hline Georgia & 1.000 & 0.260 & 1.287 & 30.0 & 3.2 & 14.6 & 0.696 & 0.170 & 0.803 \\
\hline Hawaii & 1.000 & 0.240 & 1.179 & 32.5 & 3.5 & 15.1 & 0.684 & 0.157 & 0.795 \\
\hline Idaho & 1.000 & 0.240 & 0.950 & 34.8 & 4.0 & 13.9 & 0.674 & 0.152 & 0.579 \\
\hline Illinois & 1.000 & 0.253 & 1.373 & 26.9 & 3.0 & 14.3 & 0.711 & 0.157 & 0.830 \\
\hline Indiana & 1.000 & 0.229 & 1.002 & 32.9 & 3.4 & 12.3 & 0.682 & 0.134 & 0.578 \\
\hline Iowa & 1.000 & 0.219 & 0.897 & 35.0 & 3.5 & 12.1 & 0.673 & 0.129 & 0.522 \\
\hline Kansas & 1.000 & 0.238 & 1.029 & 33.3 & 3.5 & 13.2 & 0.681 & 0.140 & 0.601 \\
\hline Kentucky & 1.000 & 0.225 & 0.846 & 34.7 & 3.6 & 10.9 & 0.674 & 0.136 & 0.498 \\
\hline Louisiana & 1.000 & 0.257 & 0.936 & 39.2 & 4.1 & 12.7 & 0.652 & 0.152 & 0.564 \\
\hline Maine & 1.000 & 0.207 & 0.921 & 35.3 & 3.4 & 13.1 & 0.671 & 0.129 & 0.562 \\
\hline Maryland & 1.000 & 0.246 & 1.357 & 31.6 & 3.2 & 15.5 & 0.689 & 0.163 & 0.897 \\
\hline Massachusetts & 1.000 & 0.251 & 1.173 & 28.6 & 3.1 & 12.0 & 0.703 & 0.163 & 0.741 \\
\hline Michigan & 1.000 & 0.241 & 1.064 & 29.0 & 3.2 & 11.8 & 0.701 & 0.149 & 0.621 \\
\hline Minnesota & 1.000 & 0.266 & 1.286 & 31.2 & 3.5 & 14.7 & 0.690 & 0.164 & 0.764 \\
\hline Mississippi & 1.000 & 0.237 & 0.826 & 39.8 & 3.8 & 11.6 & 0.650 & 0.140 & 0.490 \\
\hline Missouri & 1.000 & 0.273 & 1.182 & 35.1 & 3.9 & 14.6 & 0.672 & 0.167 & 0.704 \\
\hline Montana & 1.000 & 0.205 & 0.816 & 43.3 & 3.6 & 12.2 & 0.633 & 0.117 & 0.489 \\
\hline Nebraska & 1.000 & 0.232 & 1.016 & 36.6 & 3.9 & 13.7 & 0.665 & 0.140 & 0.602 \\
\hline Nevada & 1.000 & 0.189 & 1.004 & 25.7 & 2.5 & 11.1 & 0.717 & 0.122 & 0.629 \\
\hline New Hampshire & 1.000 & 0.250 & 1.054 & 32.3 & 3.5 & 12.4 & 0.685 & 0.157 & 0.628 \\
\hline New Jersey & 1.000 & 0.266 & 1.033 & 28.9 & 2.9 & 10.1 & 0.702 & 0.174 & 0.653 \\
\hline New Mexico & 1.000 & 0.242 & 0.956 & 36.2 & 3.9 & 13.6 & 0.667 & 0.147 & 0.601 \\
\hline New York & 1.000 & 0.217 & 0.989 & 23.7 & 2.4 & 9.9 & 0.726 & 0.143 & 0.635 \\
\hline North Carolina & 1.000 & 0.252 & 1.097 & 34.0 & 3.4 & 13.6 & 0.677 & 0.163 & 0.666 \\
\hline North Dakota & 1.000 & 0.199 & 0.761 & 37.9 & 3.6 & 11.2 & 0.659 & 0.111 & 0.449 \\
\hline Ohio & 1.000 & 0.251 & 0.954 & 32.7 & 3.6 & 11.5 & 0.683 & 0.150 & 0.560 \\
\hline Oklahoma & 1.000 & 0.281 & 1.106 & 37.5 & 4.4 & 15.0 & 0.661 & 0.166 & 0.658 \\
\hline Oregon & 1.000 & 0.282 & 1.104 & 30.1 & 4.1 & 13.9 & 0.696 & 0.178 & 0.677 \\
\hline Pennsylvania & 1.000 & 0.259 & 1.222 & 28.9 & 3.3 & 13.5 & 0.701 & 0.161 & 0.736 \\
\hline Rhode Island & 1.000 & 0.183 & 0.841 & 31.3 & 2.6 & 10.3 & 0.690 & 0.114 & 0.538 \\
\hline South Carolina & 1.000 & 0.228 & 0.935 & 34.4 & 3.4 & 12.4 & 0.676 & 0.148 & 0.573 \\
\hline South Dakota & 1.000 & 0.229 & 0.861 & 47.5 & 3.9 & 12.4 & 0.613 & 0.133 & 0.504 \\
\hline Tennessee & 1.000 & 0.259 & 1.151 & 29.4 & 3.9 & 13.7 & 0.699 & 0.155 & 0.681 \\
\hline Texas & 1.000 & 0.309 & 1.284 & 33.7 & 3.8 & 13.9 & 0.679 & 0.190 & 0.772 \\
\hline Utah & 1.000 & 0.274 & 1.321 & 35.3 & 4.1 & 17.6 & 0.671 & 0.169 & 0.795 \\
\hline Vermont & 1.000 & 0.222 & 0.911 & 35.4 & 3.5 & 12.9 & 0.670 & 0.139 & 0.560 \\
\hline Virginia & 1.000 & 0.250 & 1.172 & 34.0 & 3.4 & 13.7 & 0.677 & 0.157 & 0.750 \\
\hline Washington & 1.000 & 0.250 & 1.056 & 30.9 & 3.1 & 11.9 & 0.692 & 0.159 & 0.649 \\
\hline West Virginia & 1.000 & 0.217 & 0.722 & 36.0 & 4.0 & 10.3 & 0.668 & 0.114 & 0.434 \\
\hline Wisconsin & 1.000 & 0.228 & 1.023 & 30.0 & 3.4 & 12.8 & 0.696 & 0.137 & 0.598 \\
\hline Wyoming & 1.000 & 0.214 & 0.721 & 39.3 & 3.6 & 10.3 & 0.652 & 0.123 & 0.440 \\
\hline
\end{tabular}

Source: Implan 50 state data package, 2001 (MIG, Inc. 2004) 
Appendix Table A-4. Multipliers for the Landscape Architecture Sector

\begin{tabular}{|c|c|c|c|c|c|c|c|c|c|}
\hline \multirow[b]{2}{*}{ State } & \multicolumn{3}{|c|}{$\begin{array}{c}\text { Output (dollars per dollar } \\
\text { output) }\end{array}$} & \multicolumn{3}{|c|}{$\begin{array}{c}\text { Employment (jobs per million } \\
\text { dollars output) }\end{array}$} & \multicolumn{3}{|c|}{$\begin{array}{c}\text { Value Added (dollars per } \\
\text { dollar output) }\end{array}$} \\
\hline & Direct & Indirect & Induced & Direct & Indirect & Induced & Direct & Indirect & Induced \\
\hline Alabama & 1.000 & 0.152 & 0.952 & 12.1 & 2.4 & 12.4 & 0.746 & 0.101 & 0.571 \\
\hline Alaska & 1.000 & 0.165 & 0.852 & 11.5 & 2.1 & 10.5 & 0.746 & 0.113 & 0.574 \\
\hline Arizona & 1.000 & 0.213 & 1.178 & 12.0 & 2.8 & 14.0 & 0.746 & 0.146 & 0.722 \\
\hline Arkansas & 1.000 & 0.134 & 0.863 & 16.2 & 2.3 & 12.0 & 0.746 & 0.087 & 0.497 \\
\hline California & 1.000 & 0.239 & 1.427 & 10.1 & 2.6 & 14.3 & 0.746 & 0.165 & 0.891 \\
\hline Colorado & 1.000 & 0.227 & 1.408 & 11.0 & 2.8 & 15.5 & 0.746 & 0.157 & 0.867 \\
\hline Connecticut & 1.000 & 0.218 & 1.040 & 10.5 & 2.3 & 10.4 & 0.746 & 0.153 & 0.662 \\
\hline Delaware & 1.000 & 0.137 & 0.839 & 9.2 & 1.7 & 9.8 & 0.746 & 0.093 & 0.491 \\
\hline Florida & 1.000 & 0.227 & 1.321 & 13.3 & 3.1 & 15.6 & 0.746 & 0.157 & 0.813 \\
\hline Georgia & 1.000 & 0.219 & 1.311 & 10.7 & 2.6 & 14.8 & 0.746 & 0.151 & 0.814 \\
\hline Hawaii & 1.000 & 0.185 & 1.203 & 11.8 & 2.5 & 15.4 & 0.746 & 0.128 & 0.808 \\
\hline Idaho & 1.000 & 0.174 & 0.973 & 13.7 & 2.9 & 14.1 & 0.746 & 0.117 & 0.590 \\
\hline Illinois & 1.000 & 0.236 & 1.407 & 9.9 & 2.7 & 14.6 & 0.746 & 0.162 & 0.847 \\
\hline Indiana & 1.000 & 0.162 & 1.025 & 13.7 & 2.3 & 12.5 & 0.746 & 0.108 & 0.587 \\
\hline Iowa & 1.000 & 0.144 & 0.922 & 13.4 & 2.3 & 12.3 & 0.746 & 0.095 & 0.533 \\
\hline Kansas & 1.000 & 0.167 & 1.051 & 12.0 & 2.4 & 13.4 & 0.746 & 0.112 & 0.610 \\
\hline Kentucky & 1.000 & 0.151 & 0.870 & 13.5 & 2.4 & 11.1 & 0.746 & 0.102 & 0.509 \\
\hline Louisiana & 1.000 & 0.183 & 1.001 & 11.9 & 2.8 & 13.5 & 0.746 & 0.124 & 0.599 \\
\hline Maine & 1.000 & 0.146 & 0.952 & 13.6 & 2.3 & 13.4 & 0.746 & 0.097 & 0.575 \\
\hline Maryland & 1.000 & 0.220 & 1.408 & 10.8 & 2.7 & 16.0 & 0.746 & 0.153 & 0.928 \\
\hline Massachusetts & 1.000 & 0.228 & 1.202 & 9.2 & 2.4 & 12.2 & 0.746 & 0.159 & 0.756 \\
\hline Michigan & 1.000 & 0.193 & 1.076 & 8.8 & 2.3 & 11.8 & 0.746 & 0.132 & 0.623 \\
\hline Minnesota & 1.000 & 0.222 & 1.323 & 11.3 & 2.8 & 15.1 & 0.746 & 0.151 & 0.783 \\
\hline Mississippi & 1.000 & 0.131 & 0.854 & 14.2 & 2.2 & 11.9 & 0.746 & 0.086 & 0.504 \\
\hline Missouri & 1.000 & 0.196 & 1.215 & 11.4 & 2.7 & 15.0 & 0.746 & 0.133 & 0.720 \\
\hline Montana & 1.000 & 0.142 & 0.900 & 15.6 & 2.5 & 13.4 & 0.746 & 0.094 & 0.535 \\
\hline Nebraska & 1.000 & 0.175 & 1.068 & 13.7 & 2.8 & 14.3 & 0.746 & 0.117 & 0.628 \\
\hline Nevada & 1.000 & 0.173 & 1.028 & 10.7 & 2.2 & 11.3 & 0.746 & 0.119 & 0.640 \\
\hline New Hampshire & 1.000 & 0.181 & 1.066 & 12.6 & 2.3 & 12.4 & 0.746 & 0.124 & 0.630 \\
\hline New Jersey & 1.000 & 0.227 & 1.035 & 9.4 & 2.4 & 10.1 & 0.746 & 0.159 & 0.651 \\
\hline New Mexico & 1.000 & 0.190 & 1.004 & 13.3 & 3.1 & 14.2 & 0.746 & 0.128 & 0.628 \\
\hline New York & 1.000 & 0.229 & 1.009 & 9.9 & 2.3 & 10.0 & 0.746 & 0.161 & 0.645 \\
\hline North Carolina & 1.000 & 0.167 & 1.101 & 13.1 & 2.3 & 13.6 & 0.746 & 0.112 & 0.665 \\
\hline North Dakota & 1.000 & 0.131 & 0.803 & 13.4 & 2.1 & 11.7 & 0.746 & 0.084 & 0.471 \\
\hline Ohio & 1.000 & 0.197 & 0.988 & 12.3 & 2.8 & 11.8 & 0.746 & 0.134 & 0.577 \\
\hline Oklahoma & 1.000 & 0.175 & 1.129 & 14.8 & 2.9 & 15.2 & 0.746 & 0.116 & 0.667 \\
\hline Oregon & 1.000 & 0.210 & 1.107 & 12.5 & 3.0 & 13.8 & 0.746 & 0.144 & 0.675 \\
\hline Pennsylvania & 1.000 & 0.225 & 1.253 & 10.2 & 2.6 & 13.8 & 0.746 & 0.154 & 0.752 \\
\hline Rhode Island & 1.000 & 0.134 & 0.857 & 12.6 & 1.7 & 10.4 & 0.746 & 0.090 & 0.544 \\
\hline South Carolina & 1.000 & 0.146 & 0.942 & 12.3 & 2.0 & 12.4 & 0.746 & 0.098 & 0.573 \\
\hline South Dakota & 1.000 & 0.131 & 0.934 & 15.8 & 2.0 & 13.3 & 0.746 & 0.084 & 0.542 \\
\hline Tennessee & 1.000 & 0.186 & 1.150 & 12.0 & 2.4 & 13.6 & 0.746 & 0.126 & 0.676 \\
\hline Texas & 1.000 & 0.224 & 1.311 & 10.5 & 2.7 & 14.2 & 0.746 & 0.153 & 0.785 \\
\hline Utah & 1.000 & 0.200 & 1.360 & 14.3 & 3.0 & 18.0 & 0.746 & 0.134 & 0.813 \\
\hline Vermont & 1.000 & 0.167 & 0.941 & 15.1 & 2.5 & 13.2 & 0.746 & 0.112 & 0.573 \\
\hline Virginia & 1.000 & 0.195 & 1.209 & 10.4 & 2.3 & 14.1 & 0.746 & 0.134 & 0.773 \\
\hline Washington & 1.000 & 0.187 & 1.063 & 11.5 & 2.3 & 11.9 & 0.746 & 0.128 & 0.650 \\
\hline West Virginia & 1.000 & 0.125 & 0.753 & 13.3 & 2.0 & 10.7 & 0.746 & 0.082 & 0.451 \\
\hline Wisconsin & 1.000 & 0.182 & 1.042 & 12.9 & 2.6 & 12.9 & 0.746 & 0.122 & 0.605 \\
\hline Wyoming & 1.000 & 0.154 & 0.777 & 15.1 & 2.4 & 11.0 & 0.746 & 0.103 & 0.471 \\
\hline
\end{tabular}

Source: Implan 50 state data package, 2001 (MIG, Inc. 2004) 

Appendix Table A-5. Multipliers for the Wholesale Flowers, Nursery Stock and Florist Supply,
and Wholesale Equipment Distribution Sectors (Wholesale Trade)

\begin{tabular}{|c|c|c|c|c|c|c|c|c|c|}
\hline \multirow[b]{2}{*}{ State } & \multicolumn{3}{|c|}{ Output (dollars per dollar output) } & \multicolumn{3}{|c|}{$\begin{array}{c}\text { Employment (jobs per million } \\
\text { dollars output) }\end{array}$} & \multicolumn{3}{|c|}{$\begin{array}{l}\text { Value Added (dollars per } \\
\text { dollar output) }\end{array}$} \\
\hline & Direct & Indirect & Induced & Direct & Indirect & Induced & Direct & Indirect & Induced \\
\hline Alabama & 1.000 & 0.213 & 0.953 & 8.6 & 2.7 & 13.2 & 0.666 & 0.127 & 0.602 \\
\hline Alaska & 1.000 & 0.186 & 0.810 & 9.3 & 2.2 & 10.4 & 0.664 & 0.114 & 0.566 \\
\hline Arizona & 1.000 & 0.267 & 1.171 & 7.2 & 2.9 & 15.1 & 0.671 & 0.171 & 0.760 \\
\hline Arkansas & 1.000 & 0.207 & 0.844 & 9.3 & 2.7 & 12.5 & 0.664 & 0.120 & 0.511 \\
\hline California & 1.000 & 0.311 & 1.411 & 6.9 & 2.9 & 14.9 & 0.672 & 0.200 & 0.914 \\
\hline Colorado & 1.000 & 0.290 & 1.423 & 6.7 & 2.9 & 16.6 & 0.672 & 0.188 & 0.909 \\
\hline Connecticut & 1.000 & 0.273 & 1.045 & 5.3 & 2.4 & 11.2 & 0.677 & 0.181 & 0.703 \\
\hline Delaware & 1.000 & 0.180 & 0.845 & 6.6 & 1.9 & 10.8 & 0.673 & 0.112 & 0.536 \\
\hline Florida & 1.000 & 0.289 & 1.314 & 7.5 & 3.2 & 16.4 & 0.670 & 0.187 & 0.841 \\
\hline Georgia & 1.000 & 0.284 & 1.296 & 6.4 & 2.8 & 15.4 & 0.673 & 0.183 & 0.830 \\
\hline Hawaii & 1.000 & 0.225 & 1.168 & 10.0 & 2.7 & 16.0 & 0.661 & 0.142 & 0.823 \\
\hline Idaho & 1.000 & 0.233 & 0.931 & 9.6 & 3.3 & 14.4 & 0.663 & 0.143 & 0.594 \\
\hline Illinois & 1.000 & 0.305 & 1.385 & 6.2 & 2.8 & 15.0 & 0.674 & 0.195 & 0.860 \\
\hline Indiana & 1.000 & 0.233 & 1.029 & 8.0 & 2.7 & 13.2 & 0.668 & 0.140 & 0.618 \\
\hline Iowa & 1.000 & 0.215 & 0.919 & 8.7 & 2.8 & 13.0 & 0.666 & 0.130 & 0.558 \\
\hline Kansas & 1.000 & 0.236 & 1.050 & 8.0 & 2.8 & 14.4 & 0.668 & 0.143 & 0.636 \\
\hline Kentucky & 1.000 & 0.200 & 0.818 & 8.2 & 2.5 & 11.0 & 0.667 & 0.121 & 0.498 \\
\hline Louisiana & 1.000 & 0.226 & 0.999 & 8.9 & 2.9 & 14.6 & 0.665 & 0.137 & 0.634 \\
\hline Maine & 1.000 & 0.191 & 0.944 & 8.9 & 2.5 & 14.3 & 0.665 & 0.117 & 0.612 \\
\hline Maryland & 1.000 & 0.256 & 1.365 & 6.6 & 2.7 & 16.2 & 0.673 & 0.166 & 0.934 \\
\hline Massachusetts & 1.000 & 0.281 & 1.172 & 5.6 & 2.5 & 12.5 & 0.676 & 0.185 & 0.770 \\
\hline Michigan & 1.000 & 0.249 & 1.073 & 6.7 & 2.6 & 12.6 & 0.672 & 0.160 & 0.656 \\
\hline Minnesota & 1.000 & 0.295 & 1.311 & 6.5 & 3.0 & 15.6 & 0.673 & 0.187 & 0.805 \\
\hline Mississippi & 1.000 & 0.191 & 0.858 & 9.3 & 2.5 & 13.0 & 0.664 & 0.109 & 0.531 \\
\hline Missouri & 1.000 & 0.284 & 1.210 & 7.6 & 3.2 & 15.7 & 0.669 & 0.180 & 0.744 \\
\hline Montana & 1.000 & 0.173 & 0.840 & 10.6 & 2.6 & 13.3 & 0.659 & 0.101 & 0.526 \\
\hline Nebraska & 1.000 & 0.238 & 1.077 & 8.4 & 3.1 & 15.4 & 0.667 & 0.146 & 0.664 \\
\hline Nevada & 1.000 & 0.223 & 0.969 & 7.4 & 2.4 & 11.2 & 0.670 & 0.143 & 0.638 \\
\hline New Hampshire & 1.000 & 0.231 & 1.070 & 5.9 & 2.5 & 13.7 & 0.675 & 0.147 & 0.670 \\
\hline New Jersey & 1.000 & 0.287 & 1.034 & 5.7 & 2.5 & 10.8 & 0.676 & 0.187 & 0.687 \\
\hline New Mexico & 1.000 & 0.236 & 1.020 & 10.7 & 3.2 & 15.4 & 0.659 & 0.142 & 0.679 \\
\hline New York & 1.000 & 0.286 & 0.990 & 6.1 & 2.4 & 10.5 & 0.674 & 0.191 & 0.658 \\
\hline North Carolina & 1.000 & 0.234 & 1.091 & 8.0 & 2.7 & 14.2 & 0.668 & 0.144 & 0.687 \\
\hline North Dakota & 1.000 & 0.187 & 0.770 & 9.3 & 2.6 & 12.1 & 0.664 & 0.105 & 0.478 \\
\hline Ohio & 1.000 & 0.235 & 0.921 & 7.6 & 2.8 & 11.6 & 0.669 & 0.145 & 0.562 \\
\hline Oklahoma & 1.000 & 0.240 & 1.117 & 9.1 & 3.1 & 16.0 & 0.664 & 0.144 & 0.693 \\
\hline Oregon & 1.000 & 0.281 & 1.040 & 7.2 & 3.2 & 13.7 & 0.671 & 0.179 & 0.664 \\
\hline Pennsylvania & 1.000 & 0.292 & 1.202 & 7.3 & 2.9 & 13.8 & 0.670 & 0.183 & 0.746 \\
\hline Rhode Island & 1.000 & 0.166 & 0.832 & 7.3 & 1.8 & 10.8 & 0.670 & 0.104 & 0.567 \\
\hline South Carolina & 1.000 & 0.196 & 0.938 & 8.6 & 2.4 & 13.2 & 0.666 & 0.118 & 0.602 \\
\hline South Dakota & 1.000 & 0.188 & 0.940 & 9.1 & 2.4 & 14.5 & 0.664 & 0.112 & 0.575 \\
\hline Tennessee & 1.000 & 0.256 & 1.130 & 8.0 & 2.8 & 14.3 & 0.668 & 0.160 & 0.693 \\
\hline Texas & 1.000 & 0.290 & 1.298 & 6.3 & 2.9 & 14.7 & 0.674 & 0.182 & 0.800 \\
\hline Utah & 1.000 & 0.277 & 1.341 & 8.3 & 3.5 & 18.8 & 0.667 & 0.170 & 0.841 \\
\hline Vermont & 1.000 & 0.217 & 0.942 & 8.5 & 2.8 & 14.2 & 0.666 & 0.134 & 0.614 \\
\hline Virginia & 1.000 & 0.251 & 1.212 & 6.7 & 2.6 & 14.8 & 0.672 & 0.159 & 0.799 \\
\hline Washington & 1.000 & 0.248 & 0.983 & 7.1 & 2.5 & 11.7 & 0.671 & 0.157 & 0.628 \\
\hline West Virginia & 1.000 & 0.173 & 0.679 & 9.5 & 2.3 & 10.1 & 0.663 & 0.100 & 0.426 \\
\hline Wisconsin & 1.000 & 0.243 & 1.031 & 8.0 & 2.9 & 13.5 & 0.668 & 0.149 & 0.631 \\
\hline Wyoming & 1.000 & 0.188 & 0.754 & 8.9 & 2.5 & 11.9 & 0.665 & 0.111 & 0.492 \\
\hline
\end{tabular}

Source: Implan 50 state data package, 2001 (MIG, Inc. 2004) 
Appendix Table A-6. Multipliers for the Lawn and Garden Store and Building Materials \& Supplies Sectors

\begin{tabular}{|c|c|c|c|c|c|c|c|c|c|}
\hline \multirow[b]{2}{*}{ State } & \multicolumn{3}{|c|}{$\begin{array}{c}\text { Output (dollars per dollar } \\
\text { output) }\end{array}$} & \multicolumn{3}{|c|}{$\begin{array}{c}\text { Employment (jobs per million } \\
\text { dollars output) }\end{array}$} & \multicolumn{3}{|c|}{$\begin{array}{l}\text { Value Added (dollars per } \\
\text { dollar output) }\end{array}$} \\
\hline & Direct & Indirect & Induced & Direct & Indirect & Induced & Direct & Indirect & Induced \\
\hline Alabama & 1.000 & 0.214 & 0.943 & 17.0 & 2.6 & 12.8 & 0.674 & 0.128 & 0.586 \\
\hline Alaska & 1.000 & 0.202 & 0.822 & 15.2 & 2.3 & 10.4 & 0.684 & 0.122 & 0.566 \\
\hline Arizona & 1.000 & 0.268 & 1.167 & 15.8 & 2.9 & 14.6 & 0.680 & 0.173 & 0.743 \\
\hline Arkansas & 1.000 & 0.218 & 0.845 & 18.8 & 2.7 & 12.2 & 0.664 & 0.129 & 0.503 \\
\hline California & 1.000 & 0.298 & 1.414 & 14.5 & 2.7 & 14.7 & 0.687 & 0.193 & 0.905 \\
\hline Colorado & 1.000 & 0.287 & 1.416 & 14.8 & 2.7 & 16.2 & 0.686 & 0.187 & 0.894 \\
\hline Connecticut & 1.000 & 0.267 & 1.051 & 13.3 & 2.2 & 11.0 & 0.694 & 0.180 & 0.694 \\
\hline Delaware & 1.000 & 0.194 & 0.847 & 15.0 & 2.0 & 10.5 & 0.685 & 0.121 & 0.524 \\
\hline Florida & 1.000 & 0.289 & 1.311 & 15.8 & 3.1 & 16.0 & 0.680 & 0.187 & 0.828 \\
\hline Georgia & 1.000 & 0.277 & 1.303 & 14.2 & 2.7 & 15.2 & 0.689 & 0.180 & 0.826 \\
\hline Hawaii & 1.000 & 0.229 & 1.183 & 15.3 & 2.5 & 15.8 & 0.683 & 0.144 & 0.820 \\
\hline Idaho & 1.000 & 0.225 & 0.950 & 14.8 & 3.0 & 14.4 & 0.686 & 0.138 & 0.595 \\
\hline Illinois & 1.000 & 0.306 & 1.387 & 16.2 & 2.7 & 14.8 & 0.678 & 0.197 & 0.852 \\
\hline Indiana & 1.000 & 0.245 & 1.030 & 16.8 & 2.7 & 13.0 & 0.675 & 0.149 & 0.609 \\
\hline Iowa & 1.000 & 0.210 & 0.912 & 16.8 & 2.7 & 12.6 & 0.675 & 0.127 & 0.545 \\
\hline Kansas & 1.000 & 0.247 & 1.045 & 17.5 & 2.8 & 14.0 & 0.671 & 0.149 & 0.624 \\
\hline Kentucky & 1.000 & 0.207 & 0.830 & 16.9 & 2.5 & 11.0 & 0.674 & 0.126 & 0.499 \\
\hline Louisiana & 1.000 & 0.235 & 0.985 & 17.3 & 2.9 & 14.0 & 0.672 & 0.142 & 0.613 \\
\hline Maine & 1.000 & 0.187 & 0.934 & 16.9 & 2.5 & 13.8 & 0.675 & 0.115 & 0.592 \\
\hline Maryland & 1.000 & 0.255 & 1.368 & 15.2 & 2.6 & 16.0 & 0.684 & 0.165 & 0.924 \\
\hline Massachusetts & 1.000 & 0.271 & 1.182 & 13.4 & 2.4 & 12.4 & 0.693 & 0.179 & 0.765 \\
\hline Michigan & 1.000 & 0.261 & 1.083 & 15.2 & 2.6 & 12.4 & 0.683 & 0.169 & 0.650 \\
\hline Minnesota & 1.000 & 0.296 & 1.311 & 16.2 & 2.9 & 15.4 & 0.678 & 0.189 & 0.794 \\
\hline Mississippi & 1.000 & 0.198 & 0.846 & 18.2 & 2.6 & 12.4 & 0.667 & 0.113 & 0.515 \\
\hline Missouri & 1.000 & 0.288 & 1.218 & 16.3 & 3.2 & 15.5 & 0.677 & 0.183 & 0.739 \\
\hline Montana & 1.000 & 0.174 & 0.841 & 18.1 & 2.5 & 13.0 & 0.668 & 0.101 & 0.518 \\
\hline Nebraska & 1.000 & 0.242 & 1.057 & 18.1 & 3.0 & 14.8 & 0.667 & 0.149 & 0.641 \\
\hline Nevada & 1.000 & 0.221 & 0.995 & 14.0 & 2.3 & 11.3 & 0.690 & 0.144 & 0.642 \\
\hline New Hampshire & 1.000 & 0.231 & 1.073 & 13.8 & 2.5 & 13.3 & 0.691 & 0.148 & 0.660 \\
\hline New Jersey & 1.000 & 0.278 & 1.040 & 13.6 & 2.4 & 10.6 & 0.692 & 0.183 & 0.678 \\
\hline New Mexico & 1.000 & 0.238 & 1.002 & 17.3 & 3.2 & 14.9 & 0.672 & 0.142 & 0.654 \\
\hline New York & 1.000 & 0.283 & 0.993 & 15.3 & 2.2 & 10.3 & 0.683 & 0.191 & 0.651 \\
\hline North Carolina & 1.000 & 0.229 & 1.088 & 16.3 & 2.6 & 13.9 & 0.677 & 0.143 & 0.676 \\
\hline North Dakota & 1.000 & 0.192 & 0.767 & 18.5 & 2.6 & 11.7 & 0.665 & 0.107 & 0.467 \\
\hline Ohio & 1.000 & 0.265 & 0.952 & 16.7 & 2.9 & 11.8 & 0.675 & 0.165 & 0.572 \\
\hline Oklahoma & 1.000 & 0.251 & 1.110 & 18.2 & 3.2 & 15.6 & 0.667 & 0.149 & 0.678 \\
\hline Oregon & 1.000 & 0.280 & 1.060 & 16.1 & 3.2 & 13.7 & 0.679 & 0.179 & 0.665 \\
\hline Pennsylvania & 1.000 & 0.297 & 1.212 & 16.8 & 2.9 & 13.8 & 0.675 & 0.187 & 0.744 \\
\hline Rhode Island & 1.000 & 0.166 & 0.841 & 14.6 & 1.7 & 10.7 & 0.687 & 0.106 & 0.560 \\
\hline South Carolina & 1.000 & 0.199 & 0.935 & 16.3 & 2.3 & 12.9 & 0.678 & 0.121 & 0.590 \\
\hline South Dakota & 1.000 & 0.189 & 0.921 & 18.5 & 2.4 & 13.8 & 0.665 & 0.112 & 0.554 \\
\hline Tennessee & 1.000 & 0.252 & 1.132 & 15.8 & 2.7 & 14.0 & 0.680 & 0.157 & 0.685 \\
\hline Texas & 1.000 & 0.275 & 1.276 & 15.8 & 2.7 & 14.2 & 0.680 & 0.172 & 0.779 \\
\hline Utah & 1.000 & 0.278 & 1.344 & 16.4 & 3.5 & 18.5 & 0.677 & 0.170 & 0.829 \\
\hline Vermont & 1.000 & 0.221 & 0.939 & 16.1 & 2.8 & 13.8 & 0.678 & 0.136 & 0.599 \\
\hline Virginia & 1.000 & 0.268 & 1.213 & 16.6 & 2.7 & 14.6 & 0.676 & 0.171 & 0.791 \\
\hline Washington & 1.000 & 0.243 & 1.011 & 14.8 & 2.4 & 11.7 & 0.685 & 0.154 & 0.636 \\
\hline West Virginia & 1.000 & 0.179 & 0.691 & 18.5 & 2.3 & 10.1 & 0.666 & 0.102 & 0.427 \\
\hline Wisconsin & 1.000 & 0.246 & 1.033 & 16.2 & 2.8 & 13.3 & 0.678 & 0.152 & 0.621 \\
\hline Wyoming & 1.000 & 0.196 & 0.745 & 17.7 & 2.5 & 11.3 & 0.670 & 0.115 & 0.475 \\
\hline
\end{tabular}

Source: Implan 50 state data package, 2001 (MIG, Inc. 2004) 
Appendix Table A-7. Multipliers for the Florist Sector (Miscellaneous Retail Stores)

\begin{tabular}{|c|c|c|c|c|c|c|c|c|c|}
\hline \multirow[b]{2}{*}{ State } & \multicolumn{3}{|c|}{$\begin{array}{l}\text { Output (dollars per dollar } \\
\text { output) }\end{array}$} & \multicolumn{3}{|c|}{$\begin{array}{c}\text { Employment (jobs per million } \\
\text { dollars output) }\end{array}$} & \multicolumn{3}{|c|}{$\begin{array}{l}\text { Value Added (dollars per } \\
\text { dollar output) }\end{array}$} \\
\hline & Direct & Indirect & Induced & Direct & Indirect & Induced & Direct & Indirect & Induced \\
\hline Alabama & 1.000 & 0.397 & 0.746 & 23.9 & 4.9 & 10.0 & 0.395 & 0.238 & 0.460 \\
\hline Alaska & 1.000 & 0.363 & 0.667 & 22.1 & 4.1 & 8.4 & 0.432 & 0.220 & 0.456 \\
\hline Arizona & 1.000 & 0.445 & 1.038 & 20.2 & 4.8 & 12.9 & 0.469 & 0.286 & 0.656 \\
\hline Arkansas & 1.000 & 0.413 & 0.652 & 25.5 & 5.2 & 9.3 & 0.363 & 0.244 & 0.385 \\
\hline California & 1.000 & 0.489 & 1.301 & 19.4 & 4.4 & 13.4 & 0.486 & 0.317 & 0.828 \\
\hline Colorado & 1.000 & 0.527 & 1.241 & 22.5 & 5.0 & 14.1 & 0.423 & 0.343 & 0.779 \\
\hline Connecticut & 1.000 & 0.477 & 0.937 & 21.0 & 4.0 & 9.7 & 0.454 & 0.320 & 0.612 \\
\hline Delaware & 1.000 & 0.350 & 0.683 & 22.2 & 3.6 & 8.4 & 0.429 & 0.219 & 0.418 \\
\hline Florida & 1.000 & 0.483 & 1.177 & 20.4 & 5.2 & 14.3 & 0.466 & 0.313 & 0.739 \\
\hline Georgia & 1.000 & 0.477 & 1.169 & 20.4 & 4.6 & 13.5 & 0.466 & 0.309 & 0.738 \\
\hline Hawaii & 1.000 & 0.391 & 1.010 & 20.8 & 4.3 & 13.4 & 0.458 & 0.246 & 0.694 \\
\hline Idaho & 1.000 & 0.447 & 0.753 & 24.8 & 6.0 & 11.3 & 0.377 & 0.274 & 0.468 \\
\hline Illinois & 1.000 & 0.534 & 1.248 & 21.7 & 4.8 & 13.2 & 0.439 & 0.344 & 0.763 \\
\hline Indiana & 1.000 & 0.462 & 0.836 & 24.4 & 5.2 & 10.5 & 0.386 & 0.282 & 0.491 \\
\hline Iowa & 1.000 & 0.399 & 0.715 & 24.5 & 5.1 & 9.8 & 0.383 & 0.241 & 0.424 \\
\hline Kansas & 1.000 & 0.461 & 0.848 & 24.4 & 5.2 & 11.2 & 0.385 & 0.279 & 0.503 \\
\hline Kentucky & 1.000 & 0.376 & 0.672 & 23.3 & 4.6 & 8.8 & 0.408 & 0.229 & 0.402 \\
\hline Louisiana & 1.000 & 0.409 & 0.818 & 22.2 & 5.1 & 11.5 & 0.429 & 0.247 & 0.505 \\
\hline Maine & 1.000 & 0.354 & 0.712 & 24.5 & 4.7 & 10.4 & 0.384 & 0.217 & 0.447 \\
\hline Maryland & 1.000 & 0.433 & 1.202 & 20.5 & 4.4 & 13.9 & 0.463 & 0.279 & 0.807 \\
\hline Massachusetts & 1.000 & 0.445 & 1.082 & 18.9 & 3.9 & 11.3 & 0.496 & 0.294 & 0.696 \\
\hline Michigan & 1.000 & 0.458 & 0.947 & 21.5 & 4.6 & 10.8 & 0.443 & 0.297 & 0.565 \\
\hline Minnesota & 1.000 & 0.537 & 1.152 & 22.9 & 5.3 & 13.4 & 0.416 & 0.343 & 0.694 \\
\hline Mississippi & 1.000 & 0.348 & 0.670 & 22.9 & 4.5 & 9.7 & 0.414 & 0.200 & 0.405 \\
\hline Missouri & 1.000 & 0.543 & 1.045 & 24.1 & 6.0 & 13.2 & 0.391 & 0.346 & 0.630 \\
\hline Montana & 1.000 & 0.325 & 0.627 & 24.7 & 4.6 & 9.6 & 0.380 & 0.187 & 0.383 \\
\hline Nebraska & 1.000 & 0.436 & 0.867 & 23.6 & 5.5 & 12.0 & 0.402 & 0.267 & 0.522 \\
\hline Nevada & 1.000 & 0.388 & 0.849 & 20.9 & 4.0 & 9.6 & 0.455 & 0.253 & 0.544 \\
\hline New Hampshire & 1.000 & 0.421 & 0.905 & 21.8 & 4.5 & 11.1 & 0.438 & 0.269 & 0.552 \\
\hline New Jersey & 1.000 & 0.468 & 0.951 & 19.5 & 4.0 & 9.6 & 0.482 & 0.308 & 0.614 \\
\hline New Mexico & 1.000 & 0.404 & 0.843 & 21.5 & 5.4 & 12.3 & 0.444 & 0.241 & 0.543 \\
\hline New York & 1.000 & 0.459 & 0.919 & 19.3 & 3.5 & 9.4 & 0.486 & 0.310 & 0.599 \\
\hline North Carolina & 1.000 & 0.393 & 0.925 & 21.3 & 4.4 & 11.7 & 0.447 & 0.245 & 0.572 \\
\hline North Dakota & 1.000 & 0.348 & 0.594 & 24.0 & 4.7 & 9.0 & 0.394 & 0.194 & 0.358 \\
\hline Ohio & 1.000 & 0.446 & 0.841 & 21.0 & 4.9 & 10.3 & 0.453 & 0.279 & 0.502 \\
\hline Oklahoma & 1.000 & 0.469 & 0.894 & 24.8 & 5.9 & 12.4 & 0.378 & 0.278 & 0.541 \\
\hline Oregon & 1.000 & 0.511 & 0.927 & 23.0 & 5.8 & 11.8 & 0.414 & 0.326 & 0.578 \\
\hline Pennsylvania & 1.000 & 0.539 & 1.062 & 23.3 & 5.2 & 12.0 & 0.408 & 0.341 & 0.647 \\
\hline Rhode Island & 1.000 & 0.310 & 0.653 & 23.0 & 3.3 & 8.2 & 0.414 & 0.198 & 0.430 \\
\hline South Carolina & 1.000 & 0.348 & 0.761 & 21.9 & 4.1 & 10.4 & 0.435 & 0.213 & 0.477 \\
\hline South Dakota & 1.000 & 0.340 & 0.713 & 23.8 & 4.3 & 10.6 & 0.397 & 0.202 & 0.426 \\
\hline Tennessee & 1.000 & 0.452 & 0.962 & 22.4 & 4.9 & 11.7 & 0.426 & 0.281 & 0.578 \\
\hline Texas & 1.000 & 0.488 & 1.112 & 22.0 & 4.7 & 12.3 & 0.433 & 0.305 & 0.676 \\
\hline Utah & 1.000 & 0.495 & 1.159 & 22.5 & 6.2 & 15.8 & 0.424 & 0.304 & 0.710 \\
\hline Vermont & 1.000 & 0.408 & 0.757 & 23.4 & 5.2 & 11.0 & 0.406 & 0.251 & 0.478 \\
\hline Virginia & 1.000 & 0.487 & 1.036 & 23.1 & 5.0 & 12.4 & 0.411 & 0.310 & 0.671 \\
\hline Washington & 1.000 & 0.438 & 0.870 & 22.1 & 4.4 & 10.0 & 0.432 & 0.278 & 0.543 \\
\hline West Virginia & 1.000 & 0.341 & 0.513 & 25.5 & 4.4 & 7.5 & 0.363 & 0.194 & 0.314 \\
\hline Wisconsin & 1.000 & 0.465 & 0.846 & 24.1 & 5.3 & 10.8 & 0.391 & 0.287 & 0.505 \\
\hline Wyoming & 1.000 & 0.368 & 0.565 & 24.7 & 4.8 & 8.5 & 0.379 & 0.216 & 0.356 \\
\hline
\end{tabular}

Source: Implan 50 state data package, 2001 (MIG, Inc. 2004) 
Appendix Table A-8. Multipliers for the Food and Beverage Stores Sector

\begin{tabular}{|c|c|c|c|c|c|c|c|c|c|}
\hline \multirow{2}{*}{ State } & \multicolumn{3}{|c|}{$\begin{array}{l}\text { Output (dollars per dollar } \\
\text { output) }\end{array}$} & \multicolumn{3}{|c|}{$\begin{array}{c}\text { Employment (jobs per million } \\
\text { dollars output) }\end{array}$} & \multicolumn{3}{|c|}{$\begin{array}{l}\text { Value Added (dollars per } \\
\text { dollar output) }\end{array}$} \\
\hline & $\begin{array}{l}\text { Direct } \\
\text { Effects }\end{array}$ & $\begin{array}{l}\text { Indirect } \\
\text { Effects }\end{array}$ & $\begin{array}{l}\text { Induced } \\
\text { Effects }\end{array}$ & $\begin{array}{l}\text { Direct } \\
\text { Effects }\end{array}$ & $\begin{array}{l}\text { Indirect } \\
\text { Effects }\end{array}$ & $\begin{array}{l}\text { Induced } \\
\text { Effects }\end{array}$ & $\begin{array}{l}\text { Direct } \\
\text { Effects }\end{array}$ & $\begin{array}{l}\text { Indirect } \\
\text { Effects }\end{array}$ & $\begin{array}{c}\text { Induced } \\
\text { Effects }\end{array}$ \\
\hline Alabama & 1.000 & 0.286 & 0.870 & 21.5 & 3.5 & 11.8 & 0.564 & 0.171 & 0.539 \\
\hline Alaska & 1.000 & 0.249 & 0.777 & 17.5 & 2.8 & 9.8 & 0.610 & 0.151 & 0.534 \\
\hline Arizona & 1.000 & 0.325 & 1.131 & 17.3 & 3.5 & 14.1 & 0.612 & 0.209 & 0.718 \\
\hline Arkansas & 1.000 & 0.296 & 0.773 & 23.3 & 3.7 & 11.1 & 0.544 & 0.175 & 0.459 \\
\hline California & 1.000 & 0.350 & 1.393 & 15.6 & 3.2 & 14.4 & 0.632 & 0.227 & 0.890 \\
\hline Colorado & 1.000 & 0.346 & 1.379 & 16.6 & 3.3 & 15.7 & 0.621 & 0.225 & 0.869 \\
\hline Connecticut & 1.000 & 0.345 & 1.016 & 18.0 & 2.9 & 10.6 & 0.604 & 0.232 & 0.668 \\
\hline Delaware & 1.000 & 0.261 & 0.781 & 20.6 & 2.7 & 9.6 & 0.575 & 0.163 & 0.481 \\
\hline Florida & 1.000 & 0.405 & 1.232 & 22.5 & 4.3 & 15.0 & 0.553 & 0.262 & 0.776 \\
\hline Georgia & 1.000 & 0.384 & 1.233 & 21.1 & 3.7 & 14.4 & 0.569 & 0.249 & 0.780 \\
\hline Hawaii & 1.000 & 0.299 & 1.112 & 19.6 & 3.3 & 14.8 & 0.586 & 0.188 & 0.768 \\
\hline Idaho & 1.000 & 0.290 & 0.900 & 18.8 & 3.9 & 13.6 & 0.596 & 0.177 & 0.563 \\
\hline Illinois & 1.000 & 0.398 & 1.338 & 20.0 & 3.6 & 14.2 & 0.582 & 0.256 & 0.820 \\
\hline Indiana & 1.000 & 0.329 & 0.961 & 21.7 & 3.7 & 12.1 & 0.562 & 0.201 & 0.567 \\
\hline Iowa & 1.000 & 0.293 & 0.829 & 23.0 & 3.7 & 11.5 & 0.547 & 0.177 & 0.494 \\
\hline Kansas & 1.000 & 0.331 & 0.975 & 22.0 & 3.8 & 13.0 & 0.558 & 0.200 & 0.581 \\
\hline Kentucky & 1.000 & 0.287 & 0.760 & 22.8 & 3.5 & 10.0 & 0.549 & 0.174 & 0.455 \\
\hline Louisiana & 1.000 & 0.318 & 0.911 & 22.1 & 4.0 & 12.9 & 0.557 & 0.192 & 0.564 \\
\hline Maine & 1.000 & 0.250 & 0.855 & 21.4 & 3.3 & 12.6 & 0.565 & 0.153 & 0.540 \\
\hline Maryland & 1.000 & 0.319 & 1.314 & 18.0 & 3.3 & 15.3 & 0.604 & 0.206 & 0.885 \\
\hline Massachusetts & 1.000 & 0.370 & 1.126 & 20.0 & 3.2 & 11.8 & 0.581 & 0.244 & 0.726 \\
\hline Michigan & 1.000 & 0.350 & 1.026 & 20.6 & 3.5 & 11.7 & 0.575 & 0.227 & 0.614 \\
\hline Minnesota & 1.000 & 0.376 & 1.268 & 19.2 & 3.8 & 14.8 & 0.590 & 0.241 & 0.767 \\
\hline Mississippi & 1.000 & 0.267 & 0.769 & 22.7 & 3.5 & 11.2 & 0.551 & 0.153 & 0.466 \\
\hline Missouri & 1.000 & 0.391 & 1.153 & 21.7 & 4.3 & 14.6 & 0.562 & 0.249 & 0.698 \\
\hline Montana & 1.000 & 0.228 & 0.769 & 21.4 & 3.2 & 11.9 & 0.565 & 0.132 & 0.472 \\
\hline Nebraska & 1.000 & 0.332 & 0.973 & 23.3 & 4.2 & 13.5 & 0.544 & 0.204 & 0.588 \\
\hline Nevada & 1.000 & 0.269 & 0.955 & 16.5 & 2.8 & 10.8 & 0.622 & 0.175 & 0.615 \\
\hline New Hampshire & 1.000 & 0.331 & 0.988 & 22.0 & 3.5 & 12.2 & 0.559 & 0.211 & 0.605 \\
\hline New Jersey & 1.000 & 0.361 & 1.007 & 18.3 & 3.1 & 10.2 & 0.601 & 0.237 & 0.654 \\
\hline New Mexico & 1.000 & 0.301 & 0.945 & 19.7 & 4.0 & 13.9 & 0.585 & 0.179 & 0.613 \\
\hline New York & 1.000 & 0.380 & 0.954 & 20.6 & 2.9 & 9.8 & 0.575 & 0.257 & 0.624 \\
\hline North Carolina & 1.000 & 0.318 & 1.002 & 22.5 & 3.6 & 12.8 & 0.553 & 0.198 & 0.621 \\
\hline North Dakota & 1.000 & 0.278 & 0.674 & 25.8 & 3.8 & 10.2 & 0.516 & 0.155 & 0.408 \\
\hline Ohio & 1.000 & 0.353 & 0.901 & 21.3 & 3.9 & 11.1 & 0.567 & 0.221 & 0.540 \\
\hline Oklahoma & 1.000 & 0.330 & 1.039 & 21.8 & 4.2 & 14.5 & 0.561 & 0.196 & 0.632 \\
\hline Oregon & 1.000 & 0.359 & 1.023 & 19.4 & 4.1 & 13.1 & 0.589 & 0.229 & 0.641 \\
\hline Pennsylvania & 1.000 & 0.390 & 1.161 & 20.8 & 3.7 & 13.1 & 0.572 & 0.246 & 0.710 \\
\hline Rhode Island & 1.000 & 0.229 & 0.763 & 21.2 & 2.4 & 9.6 & 0.568 & 0.146 & 0.506 \\
\hline South Carolina & 1.000 & 0.264 & 0.863 & 20.9 & 3.1 & 11.8 & 0.572 & 0.161 & 0.543 \\
\hline South Dakota & 1.000 & 0.269 & 0.813 & 25.2 & 3.4 & 12.1 & 0.522 & 0.160 & 0.487 \\
\hline Tennessee & 1.000 & 0.333 & 1.070 & 20.4 & 3.6 & 13.2 & 0.577 & 0.207 & 0.645 \\
\hline Texas & 1.000 & 0.359 & 1.217 & 19.9 & 3.5 & 13.5 & 0.582 & 0.225 & 0.741 \\
\hline Utah & 1.000 & 0.370 & 1.270 & 21.1 & 4.6 & 17.4 & 0.569 & 0.227 & 0.781 \\
\hline Vermont & 1.000 & 0.293 & 0.874 & 20.7 & 3.7 & 12.8 & 0.573 & 0.180 & 0.556 \\
\hline Virginia & 1.000 & 0.355 & 1.148 & 20.9 & 3.6 & 13.8 & 0.571 & 0.226 & 0.746 \\
\hline Washington & 1.000 & 0.296 & 0.984 & 16.9 & 2.9 & 11.4 & 0.617 & 0.188 & 0.617 \\
\hline West Virginia & 1.000 & 0.241 & 0.628 & 22.9 & 3.1 & 9.2 & 0.549 & 0.137 & 0.386 \\
\hline Wisconsin & 1.000 & 0.348 & 0.950 & 23.3 & 4.0 & 12.2 & 0.544 & 0.215 & 0.569 \\
\hline Wyoming & 1.000 & 0.259 & 0.680 & 21.6 & 3.3 & 10.3 & 0.563 & 0.152 & 0.432 \\
\hline
\end{tabular}

Source: Implan 50 state data package, 2001 (MIG, Inc. 2004) 
Appendix Table A-9. Multipliers for the General Merchandise Stores Sector

\begin{tabular}{|c|c|c|c|c|c|c|c|c|c|}
\hline \multirow[b]{2}{*}{ State } & \multicolumn{3}{|c|}{$\begin{array}{l}\text { Output (dollars per dollar } \\
\text { output) }\end{array}$} & \multicolumn{3}{|c|}{$\begin{array}{l}\text { Employment (jobs per million } \\
\text { dollars output) }\end{array}$} & \multicolumn{3}{|c|}{$\begin{array}{l}\text { Value Added (dollars per } \\
\text { dollar output) }\end{array}$} \\
\hline & Direct & Indirect & Induced & Direct & Indirect & Induced & Direct & Indirect & Induced \\
\hline Alabama & 1.000 & 0.211 & 0.945 & 24.7 & 2.6 & 12.8 & 0.678 & 0.127 & 0.585 \\
\hline Alaska & 1.000 & 0.195 & 0.824 & 21.2 & 2.2 & 10.4 & 0.695 & 0.118 & 0.567 \\
\hline Arizona & 1.000 & 0.270 & 1.163 & 24.7 & 2.9 & 14.5 & 0.678 & 0.174 & 0.738 \\
\hline Arkansas & 1.000 & 0.220 & 0.842 & 28.2 & 2.8 & 12.2 & 0.662 & 0.130 & 0.500 \\
\hline California & 1.000 & 0.299 & 1.413 & 23.1 & 2.7 & 14.6 & 0.686 & 0.194 & 0.902 \\
\hline Colorado & 1.000 & 0.293 & 1.407 & 24.4 & 2.8 & 16.0 & 0.679 & 0.191 & 0.886 \\
\hline Connecticut & 1.000 & 0.276 & 1.046 & 23.5 & 2.3 & 10.9 & 0.684 & 0.185 & 0.687 \\
\hline Delaware & 1.000 & 0.201 & 0.835 & 26.0 & 2.1 & 10.3 & 0.672 & 0.126 & 0.514 \\
\hline Florida & 1.000 & 0.292 & 1.306 & 24.9 & 3.1 & 15.9 & 0.677 & 0.189 & 0.823 \\
\hline Georgia & 1.000 & 0.289 & 1.293 & 25.2 & 2.8 & 15.1 & 0.676 & 0.187 & 0.818 \\
\hline Hawaii & 1.000 & 0.223 & 1.188 & 22.0 & 2.4 & 15.8 & 0.691 & 0.140 & 0.820 \\
\hline Idaho & 1.000 & 0.232 & 0.944 & 25.0 & 3.1 & 14.2 & 0.677 & 0.142 & 0.590 \\
\hline Illinois & 1.000 & 0.316 & 1.381 & 26.7 & 2.8 & 14.6 & 0.669 & 0.203 & 0.847 \\
\hline Indiana & 1.000 & 0.257 & 1.017 & 28.8 & 2.9 & 12.8 & 0.659 & 0.157 & 0.599 \\
\hline Iowa & 1.000 & 0.219 & 0.899 & 28.4 & 2.8 & 12.4 & 0.661 & 0.133 & 0.536 \\
\hline Kansas & 1.000 & 0.247 & 1.043 & 26.5 & 2.8 & 13.9 & 0.670 & 0.150 & 0.621 \\
\hline Kentucky & 1.000 & 0.210 & 0.829 & 26.5 & 2.6 & 10.9 & 0.669 & 0.128 & 0.497 \\
\hline Louisiana & 1.000 & 0.241 & 0.974 & 27.8 & 3.0 & 13.8 & 0.663 & 0.146 & 0.603 \\
\hline Maine & 1.000 & 0.193 & 0.924 & 27.4 & 2.6 & 13.6 & 0.665 & 0.118 & 0.583 \\
\hline Maryland & 1.000 & 0.263 & 1.359 & 25.7 & 2.7 & 15.8 & 0.673 & 0.170 & 0.915 \\
\hline Massachusetts & 1.000 & 0.277 & 1.179 & 23.0 & 2.4 & 12.3 & 0.687 & 0.183 & 0.761 \\
\hline Michigan & 1.000 & 0.274 & 1.071 & 27.0 & 2.8 & 12.2 & 0.667 & 0.178 & 0.641 \\
\hline Minnesota & 1.000 & 0.299 & 1.308 & 25.6 & 3.0 & 15.3 & 0.674 & 0.191 & 0.791 \\
\hline Mississippi & 1.000 & 0.201 & 0.839 & 28.0 & 2.6 & 12.3 & 0.663 & 0.115 & 0.509 \\
\hline Missouri & 1.000 & 0.293 & 1.214 & 26.1 & 3.2 & 15.4 & 0.671 & 0.187 & 0.735 \\
\hline Montana & 1.000 & 0.175 & 0.839 & 27.3 & 2.5 & 12.9 & 0.666 & 0.101 & 0.515 \\
\hline Nebraska & 1.000 & 0.252 & 1.043 & 29.9 & 3.2 & 14.5 & 0.654 & 0.155 & 0.631 \\
\hline Nevada & 1.000 & 0.221 & 0.995 & 22.2 & 2.3 & 11.3 & 0.690 & 0.144 & 0.640 \\
\hline New Hampshire & 1.000 & 0.242 & 1.061 & 25.0 & 2.6 & 13.1 & 0.677 & 0.154 & 0.649 \\
\hline New Jersey & 1.000 & 0.280 & 1.040 & 22.1 & 2.4 & 10.6 & 0.691 & 0.184 & 0.675 \\
\hline New Mexico & 1.000 & 0.239 & 0.996 & 26.2 & 3.2 & 14.7 & 0.671 & 0.142 & 0.646 \\
\hline New York & 1.000 & 0.285 & 0.993 & 24.2 & 2.2 & 10.2 & 0.681 & 0.193 & 0.649 \\
\hline North Carolina & 1.000 & 0.233 & 1.085 & 25.8 & 2.6 & 13.8 & 0.673 & 0.145 & 0.672 \\
\hline North Dakota & 1.000 & 0.200 & 0.757 & 30.2 & 2.7 & 11.5 & 0.652 & 0.111 & 0.459 \\
\hline Ohio & 1.000 & 0.269 & 0.951 & 26.3 & 3.0 & 11.7 & 0.671 & 0.168 & 0.570 \\
\hline Oklahoma & 1.000 & 0.240 & 1.122 & 24.2 & 3.0 & 15.7 & 0.681 & 0.143 & 0.682 \\
\hline Oregon & 1.000 & 0.274 & 1.067 & 23.1 & 3.1 & 13.7 & 0.686 & 0.175 & 0.668 \\
\hline Pennsylvania & 1.000 & 0.301 & 1.210 & 26.6 & 2.9 & 13.7 & 0.669 & 0.190 & 0.741 \\
\hline Rhode Island & 1.000 & 0.171 & 0.834 & 24.9 & 1.8 & 10.5 & 0.677 & 0.109 & 0.552 \\
\hline South Carolina & 1.000 & 0.206 & 0.924 & 27.3 & 2.4 & 12.6 & 0.666 & 0.126 & 0.581 \\
\hline South Dakota & 1.000 & 0.195 & 0.910 & 29.8 & 2.5 & 13.6 & 0.654 & 0.116 & 0.545 \\
\hline Tennessee & 1.000 & 0.250 & 1.134 & 23.9 & 2.7 & 13.9 & 0.682 & 0.156 & 0.684 \\
\hline Texas & 1.000 & 0.269 & 1.279 & 22.9 & 2.6 & 14.2 & 0.687 & 0.168 & 0.779 \\
\hline Utah & 1.000 & 0.283 & 1.337 & 26.4 & 3.5 & 18.3 & 0.670 & 0.174 & 0.822 \\
\hline Vermont & 1.000 & 0.226 & 0.932 & 26.1 & 2.8 & 13.7 & 0.672 & 0.139 & 0.592 \\
\hline Virginia & 1.000 & 0.272 & 1.208 & 26.1 & 2.8 & 14.5 & 0.672 & 0.173 & 0.786 \\
\hline Washington & 1.000 & 0.238 & 1.020 & 21.9 & 2.4 & 11.8 & 0.691 & 0.151 & 0.640 \\
\hline West Virginia & 1.000 & 0.181 & 0.691 & 28.3 & 2.4 & 10.1 & 0.661 & 0.103 & 0.425 \\
\hline Wisconsin & 1.000 & 0.260 & 1.018 & 28.8 & 3.0 & 13.0 & 0.659 & 0.161 & 0.610 \\
\hline Wyoming & 1.000 & 0.201 & 0.735 & 28.3 & 2.6 & 11.1 & 0.661 & 0.118 & 0.466 \\
\hline
\end{tabular}




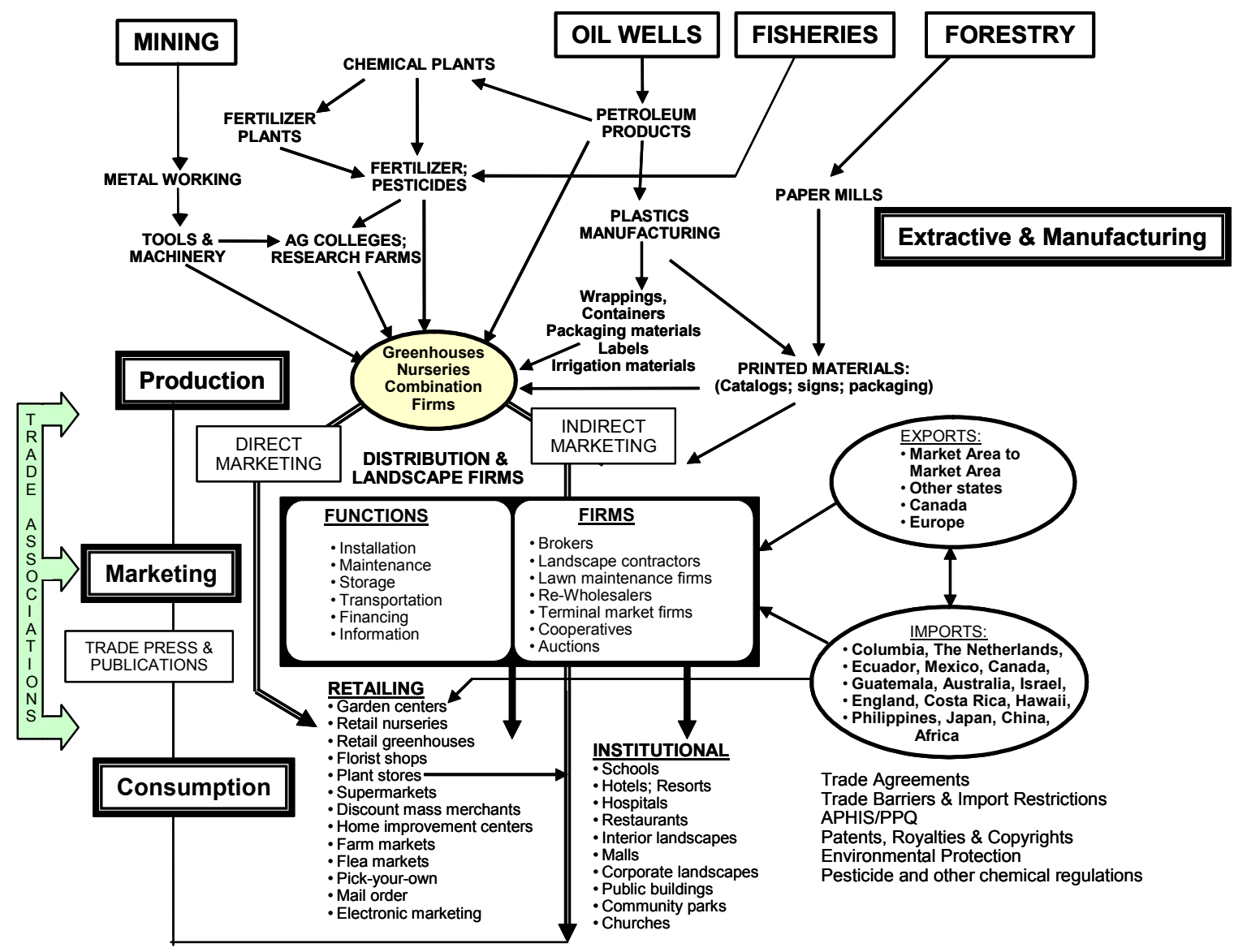

Appendix Figure A-1. Detailed Structure of the Green Industry in the United States 